\title{
Criticality Analysis of Aggregations of Actinides from Commercial Nuclear Waste in Geological Storage
}

\author{
E. J. Allen
}




\section{DISCLAIMER}

This report was prepared as an account of work sponsored by an agency of the United States Government. Neither the United States Government nor any agency Thereof, nor any of their employees, makes any warranty, express or implied, or assumes any legal liability or responsibility for the accuracy, completeness, or usefulness of any information, apparatus, product, or process disclosed, or represents that its use would not infringe privately owned rights. Reference herein to any specific commercial product, process, or service by trade name, trademark, manufacturer, or otherwise does not necessarily constitute or imply its endorsement, recommendation, or favoring by the United States Government or any agency thereof. The views and opinions of authors expressed herein do not necessarily state or reflect those of the United States Government or any agency thereof. 


\section{DISCLAIMER}

Portions of this document may be illegible in electronic image products. Images are produced from the best available original document. 


\section{Printed in the United States of America. Available from National Technical Information Service \\ U.S. Department of Commerce \\ 5285 Port Royal Road, Springfield, Virginia 22161 \\ Price: Printed Copy $\$ 8.00$; Microfiche $\$ 3.00$}

This report was prepared as an account of work sponsored by an agency of the United States Government. Neither the United States Government nor any agency thereof, nor any of their employees, contractors, subcontractors, or their employees, makes any warranty, express or implied, nor assumes any legal liability or responsibility for any third party's use or the results of such use of any information, apparatus, product or process disclosed in this report, nor represents that its use by such third party would not infringe privately owned rights. 
ORNL/TM-6458

Dist. Category UC -70

Contract No. W-7405-eng-26

Engineering Technology Division

CRITICALITY ANALYSIS OF AGGREGATIONS OF ACTINIDES FROM

COMMERCTAL NUCLEAR WASTE IN GEOLOGICAL STORAGE

E. J. Allen

Date Published: Nugust 1978

\section{NOTICE MN ONLY \\ PORTIONS OF THIS REPORT ARE ILLEGIBLE. It \\ has been reproduced from the best available copy to permit the broadest possible avail. ability.}

Prepared by the

OAK RIDGE NATIONAL LABORATORY

Dak Ridge, Tennessee 37830

operated by

UNION CARBIDE CORPORATION

for the

DEPARTMENT OF ENERGY 
THIS PAGE

WAS INTENTIONALLY

LEFT BLANK 
CONTENTS

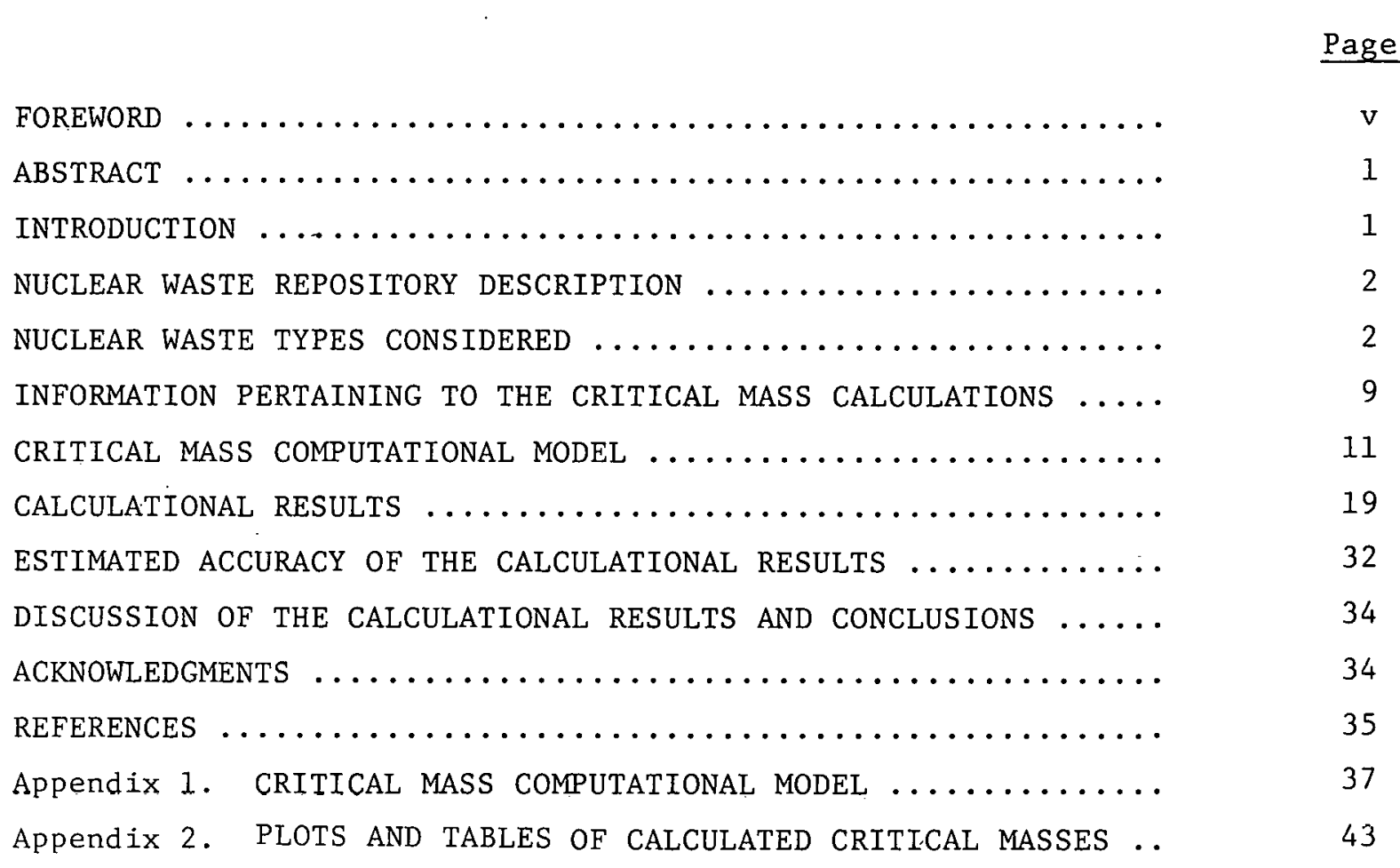


THIS PAGE

WAS INTENTIONALLY

LEFT BLANK 
FOREWORD

This report was prepared by the Engineering Technology Division of Union Carbide Corporation, Nuclear Division, in cooperation with the Office of Waste Isolation for the National Waste Terminal Storage Program. The objective of this OWI program is to establish facilities in various deep geologic formations at several locations in the United States for the safe disposal of commercial nuclear waste. This reported work is in support of this objective. 


\title{
CRITICALITY ANALYSIS OF AGGREGATIONS OF ACTINIDES FROM COMMERCIAL NUCLEAR WASTE IN GEOLOGICAL STORAGE
}

\author{
E. J. Allen
}

ABSTRACT

An underground nuclear-waste terminal-storage facility for either spent fuel elements or high level waste from a reprocessing plant will contain large amounts of fissionable actinides. Such a facility must be designed to preclude the concentration of these isotopes into a critical mass. Information on the critical masses of the various isotopes present in spent fuel or high level waste is required as part of such a design effort. This study provides this information. The results of this study will be used, in conjunction with geologic transport rates of the actinide compounds, to estimate mass formation probabilities in waste repositories.

A computational model was developed as part of the study to perform criticality calculations rapidly and efficiently and to produce tables and plots of actinide concentration in geologic material versus critical mass. The criticality model uses a discrete ordinates approximation to neutron transport theory and treats six energy groups and spherical geometry. Neutron cross sections were obtained from ENDF/B-IV or. ENDF/B-V cross section libraries. Critical masses calculated with the computational model were checked against experimental values and against more detailed calculational values and were found to be from $30 \%$ less to $10 \%$ greater.

Critical mass calculations were made for five waste types, five waste ages, five actinide elements, and four geologic compositions. Minimum critical masses were calculated for over 400 combinations of the above variables. The relative importance for criticality of the various actinides and waste types is presented in terms of the number of possible critical masses per waste container.

Key words: nuclear waste, critical mass, actinides, calculations, computer codes.

\section{INTRODUCTION}

A nuclear waste repository for spent fuel or high level wastes from a fuel reprocessing plant will contain large amounts of the actinide elements; $\mathrm{U}, \mathrm{Np}, \mathrm{Pu}, \mathrm{Am}$, and $\mathrm{Cm}$. Since many of the isotopes of these elements are fissionable, the repository must be designed to prevent a critical mass 
being formed as a result of selective leaching and/or selective transport and selective deposition of one or more of the fissionable actinides.

The results of considerations to date indicate very low possibilities of an assembly of actinides being formed which would meet all of the requirements for criticality; namely, required amounts of actinides, purity, geometric shape and size, and neutron moderation and reflection. ${ }^{1}$ To help in further assessments of the criticality possibilities, criticality calculations were made for a wide range of assumed repository conditions for the actinides in nuclear wastes from each of several diftèrent tucl cyclcs.

NUCLEAR WASTE RE'POSLI'ORY DESCRIPTION

Preliminary waste repository designs indicate that the high-level waste canisters will be placed in vertical holes in underground chambers. The holes containing the canisters will be placed in a single or double row down the center of each chamber and spaced $\sim 2$ to 3 meters apart. There will be several high-level waste chambers in each repository. A similar design will result if fuel elements rather than High Level Waste (HLW) canisters are 'stored.

Geologic structures considered suitable for terminal storage nf nuclear waste include structures composed of salt, granite, or shale. The repository structure and site are selected partially for long-term stability properties. These include infrequency of earthquake.s, 10w probability of groundwater intrusion, and absence of surface drillings.

A more complete description on nuclear-waste terminal-storage facilities is presented in Ref. 2 .

\section{NUCLEAR WASTE TYPES CONSIDERED}

Five nuclear waste types were considered in this study. The waste types are summarized in Table 1 and will be specified throughout this paper as being of types $1-5$ as in the table.

All five waste types were assumed to be from 1ight-water reactor fuel since most of the nuclear waste generated for the first terminalstorage facility will come from such reactors. The fuel. was assumed to 
Table 1. Descriptions of the nuclear waste types considered

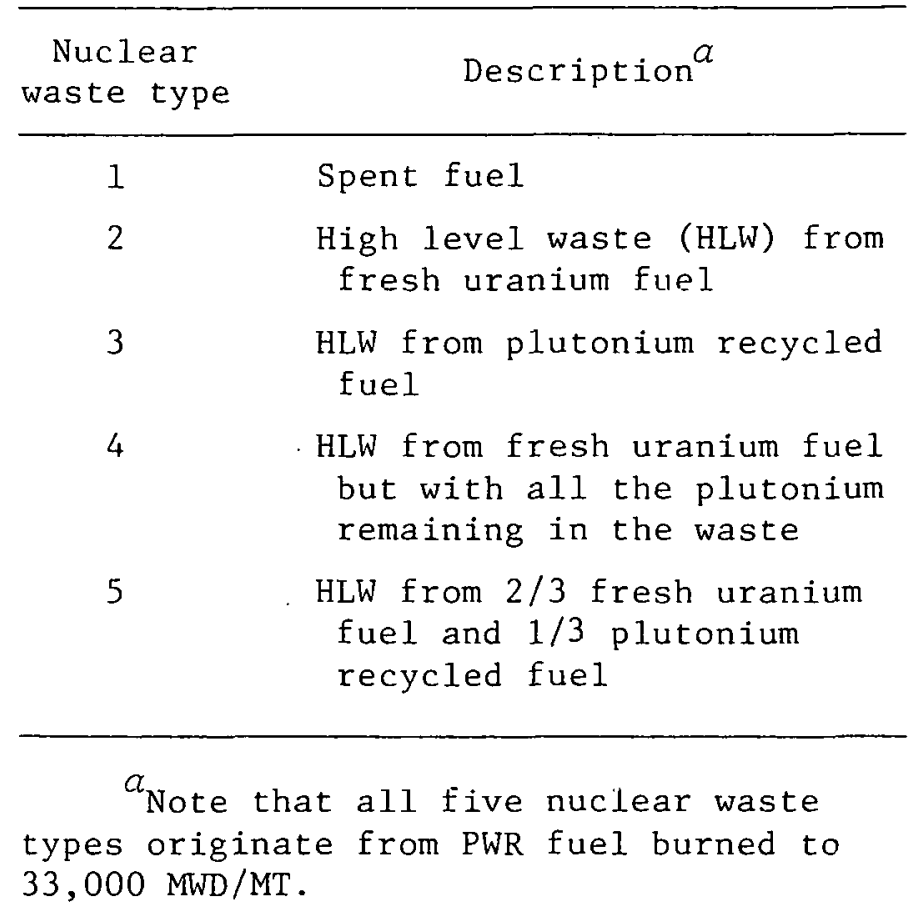

have undergone a burnup of $33,000 \mathrm{MWD} / \mathrm{MT}$. For the waste types other than spent fuel, reprocessing was assumed to occur one year after discharge from the reactor. In waste types 2 through $5,99.5 \%$ of the uranium was assumed to be removed during reprocessing. In type four waste, the plutonium was not removed during reprocessing and remained in the waste. In types 2, 3, and 5 waste, $99.5 \%$ of the plutonium was removed. Type 5 waste is representative high-level waste of a pressurized-water reactor (PWR) operating with plutonium recycle of the plutonium to the reactor. Since the critical mass of a particular actinide with a particular moderator and reflector is dependent on the isotopic composition of the actinide, the isotopic compositions of the five most important actinides were calculated for the five waste types and for five waste ages. The isotopic compositions change with time due to decay of the nuclides in the waste. The decay calculations were performed by the Office of Waste Isolation in their fiscal year 1977 projections with the isotope generation and depletion code ORIGEN. ${ }^{3}$ 
In Tables $2-6$, the isotopic weight fractions of five actinide elements for the five waste types are presented. Note that the isotopic weight fractions are given for oxides of the actinides. The time periods or ages of the waste refer back to when the fuel was discharged from the reactor.

Table 2. Tsotnnir weight frartions of uranium in nuclear waste

\begin{tabular}{|c|c|c|c|c|c|c|}
\hline \multirow{2}{*}{$\begin{array}{c}\text { Nuclear } \\
\text { waste } \\
\text { typs }\end{array}$} & \multirow[t]{2}{*}{$\begin{array}{c}\text { Age } \\
(y \operatorname{cor} 3)\end{array}$} & \multicolumn{4}{|c|}{$\begin{array}{l}\text { Weight traction of uranium } \\
\text { isotopes in uranium oxide }\end{array}$} & \multirow{2}{*}{$\begin{array}{l}\text { Kilograms uraniun } \\
\text { per metric ton of } \\
\text { fuel charged }\end{array}$} \\
\hline & & $2{ }^{34} \mathrm{U}$ & ${ }^{2}{ }^{5} \mathrm{U}$ & $236 \mathrm{U}$ & $2{ }^{38} \mathrm{U}$ & \\
\hline 1 & 10 & 0.00016 & 0.00743 & 0.00379 & 0.87098 & 955.3 \\
\hline 1 & 100 & 0.00022 & 0.00744 & 0.00380 & 0.87089 & 955.4 \\
\hline 1 & 1,000 & 0.00027 & 0.00756 & 0.00398 & 0.87054 & 955.8 \\
\hline 1 & 10,000 & 0.00027 & 0.00862 & 0.00507 & 0.86839 & 958.2 \\
\hline 1 & 100,000 & 0.00022 & 0.01201 & 0.00576 & 0.86442 & 962.6 \\
\hline 2 & 10 & 0.00018 & 0.00743 & 0.00379 & 0.87095 & 4.77 \\
\hline 2 & 100 & 0.00039 & 0.00745 & 0.00384 & 0.87067 & 4.77 \\
\hline 2 & 1,000 & 0.00068 & 0.00759 & 0.00438 & 0.86970 & 4.78 \\
\hline 2 & 10,000 & 0.00067 & 0.00998 & 0.00770 & 0.86400 & 4.81 \\
\hline 2 & 100,000 & 0.00052 & 0.02587 & 0.00969 & 0.84632 & 4.91 \\
\hline 3 & 10 & 0.00049 & 0.00290 & 0.00068 & 0.87828 & 4.65 \\
\hline 3 & 100 & 0.00340 & 0.00291 & 0.00164 & 0.87435 & 4.67 \\
\hline 3 & 1,000 & 0.01035 & 0.00342 & 0.01259 & 0.85599 & 4.77 \\
\hline 3 & 10,000 & 0.00927 & 0.02493 & 0.07345 & 0.77470 & 5.27 \\
\hline 3 & 100,000 & 0.00569 & 0.17423 & 0.09002 & 0.61246 & 6.69 \\
\hline 4 & 10 & 0.00379 & 0.00839 & $0.0 \cap 750$ & 0,86267 & 4.80 \\
\hline 4 & 100 & 0.02789 & 0.01055 & 0.01082 & 0.83310 & 4.97 \\
\hline 4 & 1,000 & 0.04730 & 0.03186 & 0.04096 & 0.76225 & 5.43 \\
\hline 4 & 10,000 & 0.03199 & 0.15768 & 0.16332 & 0.52937 & 7.83 \\
\hline 4 & 100,000 & 0.01567 & 0.37095 & 0.15817 & 0.33761 & 12.44 \\
\hline 5 & 10 & 0.00028 & 0.00595 & 0.00277 & 0.87335 & 4.73 \\
\hline 5 & 100 & 0.00140 & 0.00596 & 0.00312 & 0.87188 & .4 .74 \\
\hline 5 & 1,000 & 0.00300 & 0.00620 & 0.00711 & 0.86514 & 4.78 \\
\hline 5 & 10,000 & 0.00371 & 0.01527 & 0.03098 & 0.83239 & 4.96 \\
\hline 5 & 100,000 & 0.00261 & 0.08596 & 0.04222 & 0.75161 & 5.50 \\
\hline
\end{tabular}


Table 3. Isotopic weight fractions of neptunium in nuclear waste

\begin{tabular}{rrrr}
\hline $\begin{array}{c}\text { Nuclear } \\
\text { waste } \\
\text { type }\end{array}$ & $\begin{array}{c}\text { Age } \\
\text { (years) }\end{array}$ & $\begin{array}{c}\text { Weight fraction of } \\
\text { neptunium isotopes } \\
\text { in neptunium oxide }\end{array}$ & $\begin{array}{c}\text { Kilograms neptunium } \\
\text { per metric ton of } \\
\text { fuel charged }\end{array}$ \\
\cline { 3 - 3 } 1 & & ${ }^{237} \mathrm{~Np}$ & \\
\hline 1 & 10 & 0.882 & 0.467 \\
1 & 1,000 & 0.882 & 0.614 \\
1 & 10,000 & 0.882 & 1.47 \\
2 & 10 & 0.882 & 1.73 \\
2 & 100 & 0.882 & 0.464 \\
2 & 1,000 & 0.882 & 0.478 \\
2 & 10,000 & 0.882 & 0.547 \\
3 & 10 & 0.882 & 0.567 \\
3 & 100 & 0.882 & 0.176 \\
3 & 1,000 & 0.882 & 0.276 \\
3 & 10,000 & 0.882 & 0.771 \\
4 & 10 & 0.882 & 0.964 \\
4 & 100 & 0.882 & 0.968 \\
4 & 1,000 & 0.882 & 1.11 \\
4 & 10,000 & 0.882 & 1.94 \\
5 & 10 & 0.882 & 2.20 \\
5 & 100 & 0.882 & 0.368 \\
5 & 1,000 & 0.882 & 0.611 \\
5 & 10,000 & 0.882 & 0.699 \\
\hline & & 0.882 & \\
\hline & & & \\
\hline
\end{tabular}


Tajle 4. Isotopic weight fractions of plutonium in nuclear waste

\begin{tabular}{|c|c|c|c|c|c|c|c|}
\hline \multirow{2}{*}{$\begin{array}{l}\text { Nuciear } \\
\text { waste } \\
\text { type }\end{array}$} & \multirow{2}{*}{$\begin{array}{c}\text { Age } \\
(\text { year } \leq)\end{array}$} & \multicolumn{5}{|c|}{$\begin{array}{l}\text { Weight fractions of the plutonium } \\
\text { isotopes in plutonium oxide }\end{array}$} & \multirow{2}{*}{$\begin{array}{l}\text { Kilograms plutonium } \\
\text { per metric ton of } \\
\text { fuel charged }\end{array}$} \\
\hline & & $23.3 \mathrm{Pu}$ & $239 \mathrm{P} \cdot$ & $240 \mathrm{Pu}$ & $241 \mathrm{Pu}$ & $242 \mathrm{Pu}$ & \\
\hline 1 & 10 & $0.0_{-29}^{-29}$ & 0.531 & 0.219 & 0.0764 & 0.0437 & 8.96 \\
\hline$!$ & $1 C 0$ & 0.00707 & 0.585 & 0.240 & 0.00118 & 0.0483 & 8.11 \\
\hline 1 & $1.0 C 0$ & 0.00001 & 0.531 & 0.231 & 0.0 & 0.0507 & 7.71 \\
\hline 1 . & 10,000 & 0.0 & 0.678 & 0.132 & 0.0 & 0.0720 & 5.35 \\
\hline 2 & 10 & 3.0374 & $0.4 \div 8$ & 0.296 & 0.0644 & 0.0369 & 0.0532 \\
\hline 2 & 100 & 3.0171 & 0.379 & 0.455 & 0.00074 & 0.0310 & 0.0646 \\
\hline 2 & 1,000 & כ.0־013 & 0.445 & 0.407 & 0.00001 & 0.0309 & 0.0671 \\
\hline 2 & 10,000 & 3.0 & 0.720 & 0.136 & 0.0 & 0.0259 & 0.0795 \\
\hline 3 & 10 & D. 0537 & 0.138 & 0.575 & 0.0460 & 0.0593 & 0.359 \\
\hline 3 & 103 & 1). $0 \geq 22$ & 0.0760 & 0.754 & 0.00046 & 0.0296 & 0.786 \\
\hline 3 & $1,00 J$ & 0.00047 & 0.184 & 0.664 & 0.00015 & 0.0338 & 0.831 \\
\hline 3 & $10,00 J$ & 0.0 & 0.638 & 0.212 & 0.00006 & 0.0318 & 1.04 \\
\hline 4 & 13 & 0.0265 & 0.531 & 0.213 & 0.0726 & 0.0395 & 9.20 \\
\hline 4 & 100 & $0.0=46$ & 0.587 & 0.236 & 0.00113 & 0.0439 & 8.28 \\
\hline 4 & 1,001 & 0.00001 & 0.608 & 0.227 & 0.0 & 0.0466 & 7.80 \\
\hline 4 & 10,000 & 0.0 & 0.686 & 0.131 & 0.0 & 0.0661 & 5.41 \\
\hline 5 & 10 & 9.0577 & 0.2019 & 0.511 & 0.0502 & 0.0541 & 0.155 \\
\hline 5 & 100 & 0.0215 & 0.119 & 0.712 & 0.00050 & 0.0298 & 0.305 \\
\hline 5 & 1,300 & {$[1.00] 43$} & 0.220 & 0.629 & 0.00013 & 0.0334 & 0.322 \\
\hline 5 & 10,000 & 6.0 & 0.649 & 0.202 & 0.00005 & 0.0310 & 0.399 \\
\hline
\end{tabular}


Table 5. Isotopic weight fractions of americium in nuclear waste

\begin{tabular}{|c|c|c|c|c|c|}
\hline \multirow{2}{*}{$\begin{array}{l}\text { Nuclear } \\
\text { waste } \\
\text { type }\end{array}$} & \multirow{2}{*}{$\begin{array}{c}\text { Age } \\
\text { (years) }\end{array}$} & \multicolumn{3}{|c|}{$\begin{array}{l}\text { Weight fractions of } \\
\text { americium isotopes in } \\
\text { americium oxide }\end{array}$} & \multirow{2}{*}{$\begin{array}{l}\text { Kilograms americium } \\
\text { per metric ton of } \\
\text { fuel charged }\end{array}$} \\
\hline & & $24^{11} \mathrm{Am}$ & $242 \mathrm{~m}_{\mathrm{Am}}$ & $243 \mathrm{Am}$ & \\
\hline 1 & 10 & 0.750 & 0.00105 & 0.131 & 0.601 \\
\hline 1 & 100 & 0.818 & 0.00034 & 0.0640 & 1.22 \\
\hline 1 & 1,000 & 0.677 & 0.00002 & 0.205 & 0.351 \\
\hline 1 & 10,000 & 0.00014 & 0.0 & 0.882 & 0.0361 \\
\hline 2 & 10 & 0.471 & 0.00327 & 0.408 & 1.93 \\
\hline 2 & 100 & 0.450 & 0.00231 & 0.431 & 0.181 \\
\hline 2 & 1,000 & 0.187 & 0.00007 & 0.695 & 0.103 \\
\hline 2 & 10,000 & 0.00014 & 0.0 & 0.882 & 0.0361 \\
\hline 3 & 10 & 0.297 & 0.0146 & 0.571 & 2.20 \\
\hline 3 & 100 & 0.278 & 0.0102 & 0.594 & 2.08 \\
\hline 3 & 1,000 & 0.0968 & 0.00024 & 0.785 & 1.45 \\
\hline 3 & 10,000 & 0.00316 & 0.0 & 0.879 & 0.575 \\
\hline 4 & 1.0 & 0.760 & 0.00105 & 0.121 & 0.579 \\
\hline 4 & 100 & 0.823 & 0.00034 & 0.0590 & 1.18 \\
\hline 4 & 1.000 & 0.691 & 0.00002 & 0.191 & 0.336 \\
\hline 4 & 10,000 & 0.00014 & 0.0 & 0.882 & 0.0321 \\
\hline 5 & 10 & 0.323 & 0.0129 & 0.546 & 0.860 \\
\hline 5 & 100 & 0.304 & 0.00905 & 0.570 & 0.814 \\
\hline 5 & 1,000 & 0.108 & 0.00022 & 0.774 & 0.552 \\
\hline 5 & 10,000 & 0.00282 & 0.0 & 0.880 & 0.216 \\
\hline
\end{tabular}


Table 6. Isotopic weight fractions of curium in nuclear waste

\begin{tabular}{|c|c|c|c|c|c|c|c|}
\hline \multirow{2}{*}{$\begin{array}{l}\text { Nuclear } \\
\text { waste } \\
\text { type }\end{array}$} & \multirow{2}{*}{$\begin{array}{c}\text { Age } \\
\text { (years) }\end{array}$} & \multicolumn{5}{|c|}{$\begin{array}{l}\text { Weight fraction of curium } \\
\text { isotopes in curium oxide }\end{array}$} & \multirow{2}{*}{$\begin{array}{l}\text { Kilograms curium } \\
\text { per metric ton } \\
\text { of fuel charged }\end{array}$} \\
\hline & & $24^{2} \mathrm{Cm}$ & $2{ }^{43} \mathrm{Cm}$ & $2{ }^{44} \mathrm{Cm}$ & ${ }^{245} \mathrm{Cm}$ & $246 \mathrm{Cm}$ & \\
\hline 1 & 10 & 0.00009 & 0.00267 & 0.865 & 0.0129 & 0.00154 & 0.0169 \\
\hline 1 & 100 & 0.00124 & 0.00792 & 0.574 & 0.267 & 0.0316 & 0.000813 \\
\hline 1 & 1,000 & 0.00007 & 0.0 & 0.0 & 0.794 & 0.0888 & 0.000254 \\
\hline 1 & 10,000 & 0.0 & 0.0 & 0.0 & 0.830 & 0.0525 & 0.000114 \\
\hline 2 & 10 & 0.00009 & 0.00267 & 0.865 & 0.0129 & 0.00154 & 0.0169 \\
\hline 2 & 1.00 & 0.001 .24 & 0.00792 & 0.574 & 0.267 & 0.0316 & ก. กกกร13 3 \\
\hline$?$ & 1,000 & 0.00007 & 0.0 & 0.0 & 0.794 & 0.0888 & 0.000254 \\
\hline 2 & 10,000 & 0.0 & 0.0 & 0.0 & 0.030 & 0.0525 & 0.000114 \\
\hline 3 & 10 & 0.00014 & 0.00075 & 0.728 & 0.138 & 0.0152 & 0.564 \\
\hline 3 & 100 & 0.00046 & 0.00053 & 0.116 & 0.690 & 0.0754 & 0.112 \\
\hline 3 & 1,000 & 0.00001 & 0.0 & 0.0 & 0.800 & 0.0826 & 0.0898 \\
\hline 3 & 10,000 & 0.0 & 0.0 & 0.0 & 0.834 & 0.0488 & 0.0405 \\
\hline 4 & 10 & 0.00010 & 0.00282 & 0.865 & 0.0126 & 0.00143 & 0.0144 \\
\hline 4 & 100 & 0.00142 & 0.00845 & 0.580 & 0.263 & 0.0297 & 0.000684 \\
\hline 4 & 1,000 & 0.00008 & 0.0 & 0.0 & 0.797 & 0.0848 & 0.000209 \\
\hline 4 & 10,000 & 0.0 & 0.0 & 0.0 & 0.832 & 0.0502 & 0.0000943 \\
\hline 5 & 10 & 0.00013 & 0.00086 & 0.736 & 0.131 & 0.0145 & 0.199 \\
\hline 5 & 100 & 0.00047 & 0.00064 & 0.123 & 0.684 & 0.0748 & 0.0380 \\
\hline 5 & 1,000 & 0.00001 & 0.0 & 0.0 & 0.800 & 0.0827 & 0.0301 \\
\hline 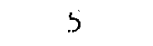 & 10,000 & 0.0 & 0.0 & 0.0 & 0.834 & 0.0488 & 0.0136 \\
\hline
\end{tabular}

Five actinides were considered in this study. These were uraniun, neptunium, plutonium, americium, and curium. Heavier actinides were not. considered as they were not discharged in enough abundance to cause a criticality problem. Of the five actinides considered, uranium had to be followed for a longer time than the others because of the long half-lives of the uranium isotopes and because the isotope ${ }^{235} \mathrm{U}$ continued to increase in relative abundance. Critical mass calculations for uranium were performed to a waste age of 100,000 years: the other actinides were only considered to a waste age of 10,000 years.

In Tables $2-6$, the heavy metal masses in the nuclear waste per metric ton of heavy metal charged to the reactor are presented in addition to the isotopic weight fractions. There arc two types of waste containers; the spent fuel element of waste type 1 and the HLW container of the other waste types. There are approximately 0.523 metric tons of heavy-metal oxide initially present in each spent fuel element and 2.38 metric tons of 
heavy-metal oxide reprocessed per HLW container. ${ }^{4}$ Using this information and the information in Tables $2-6$, the heavy-metal oxide masses per waste container can be calculated and are presented in Table 7 .

Table 7. Masses of various actinide oxides per nuclear waste container

\begin{tabular}{|c|c|c|c|c|c|c|c|}
\hline \multirow{2}{*}{$\begin{array}{c}\text { Nuclear } \\
\text { waste } \\
\text { type }\end{array}$} & \multirow{2}{*}{$\begin{array}{c}\text { Age } \\
\text { (years) }\end{array}$} & \multicolumn{5}{|c|}{ Mass of actinide oxide per waste container $(\mathrm{kg})$} & \multirow[b]{2}{*}{ Total } \\
\hline & & Uranium & Neptunium & Plutonium & Americium & Curium & \\
\hline 1 & 10 & 499.5 & 0.244 & 4.69 & 0.314 & 0.0089 & 504.8 \\
\hline 1 & 100 & 499.6 & 0.321 & 4.24 & 0.637 & 0.000425 & 504.8 \\
\hline 1 & 1,000 & 499.8 & 0.769 & 4.03 & 0.183 & 0.000133 & 504.8 \\
\hline 1 & 10,000 & 501.0 & 0.905 & 2.80 & 0.0189 & 0.000060 & 504.7 \\
\hline 1 & 100,000 & 503.4 & & 0.362 & & & \\
\hline 2 & 10 & 11.36 & 1.10 & 0.127 & 0.459 & 0.0403 & 13.09 \\
\hline 2 & 100 & 11.36 & 1.14 & 0.154 & 0.431 & 0.00193 & 13.08 \\
\hline 2 & 1,000 & 11.37 & 1.30 & 0.160 & 0.246 & 0.000603 & 13.08 \\
\hline 2 & 10,000 & 11.45 & 1.35 & 0.189 & 0.0859 & 0.000271 & 13.07 \\
\hline 2 & 100,000 & 11.69 & & 0.0262 & & & \\
\hline 3 & 10 & 11.07 & 0.419 & 0.854 & 5.22 & 1.34 & 18.91 \\
\hline 3 & 100 & 11.12 & 0.657 & 1.87 & 4.95 & 0.267 & 18.87 \\
\hline 3 & 1,000 & 11.36 & 1.84 & 1.98 & 3.45 & 0.214 & 18.84 \\
\hline 3 & 10,000 & 12.55 & 2.29 & 2.47 & 1.37 & 0.0965 & 18.78 \\
\hline 3 & 100,000 & 15.91 & & 0.370 & & & \\
\hline 4 & 10 & 11.42 & 2.30 & 21.89 & 1.38 & 0.0342 & 37.02 \\
\hline 4 & 100 & 11.82 & 2.64 & 19.71 & 2.81 & 0.00163 & 36.98 \\
\hline 4 & 1,000 & 12.92 & 4.62 & 18.57 & 0.799 & 0.000498 & 36.91 \\
\hline 4 & 10,000 & 18.64 & 5.24 & 12.86 & 0.0764 & 0.000224 & 36.81 \\
\hline 4 & 100,000 & 29.61 & & 1.60 & & & \\
\hline 5 & 10 & 11.26 & 0.876 & 0.369 & 2.05 & 0.474 . & 15.03 \\
\hline 5 & 100 & 11.28 & 0.977 & 0.726 & 1.94 & 0.0904 & 15.01 \\
\hline 5 & 1,000 & 11.37 & 1.48 & 0.766 & 1.31 & 0.0716 & 15.00 \\
\hline 5 & 10,000 & 11.81 & 1.66 & 0.948 & 0.513 & 0.0323 & 14.97 \\
\hline 5 & 100,000 & 13.09 & & 0.141 & & & \\
\hline
\end{tabular}

INFORMATION PERTAINING TO THE

CRITICAL MASS CALCULATIONS

Information pertinent to the critical mass calculations is presented in this section. In the discussion which follows, the moderator is defined to be the material with which the actinide compounds are mixed, whether it is water, brine, granite, or salt. The reflector is the outer shell or 
annulus of material which does not contain actinide compounds but may be the same material as the moderator.

All calculations in this study assumed a spherical geometry. For a given composition of actinide compounds in a moderator material, the critical mass is least for a sphere of the composition.

For a given moderator, reflector, and actinide compound, there exists a specific concentration of actinide compound in moderator at which the critical mass is minimum. Several interacting effecto, described in Ref. 5, result in a minimum in the curve of critical mass versus artinide concentration in moderator. This minimum for each moderator, reflector, and actinide compound will be referred to as the minimum rititiral mass throughout this paper.

The critical masses were calculated for homogeneous spherical mixtures of actinide compounds in moderator material. Heterogeneous mixtures were not studied. However, if high concentrations of resonance absorbers such as ${ }^{238} \mathrm{U}$ or ${ }^{240} \mathrm{Pu}$ are present, it is possible that a heterogeneous mixture of lower critical mass can be formed than that calculated for a homogeneous mixture of same actinide compounds in moderator.

Four geologic materials were considered; water, brine, granite or shale, and salt. The elemental compositions of granite and shalo arc similar but vary from one site to another. A reasonable overall composition was selected and this material will be referred to as granite throughout the remainder of the paper. Water may be present in a granite repository but water in a sal.t repository will result in brine. Some properties of each of these materials are presented in Table 8 .

The moderator-reflector material arrangements studied were waterwater, brine-brine, granite-granite, and salt-salt. Test cases were calculated for water-granite and brine-salt systems. The results of these test cases indicate that for low concentrations of actinide compound in moderator the reflector composition has only a small effect on the calculated critical mass. For high concentrations of actinide compounds, granite and salt reflected systems generally have lower critical masses. Mixtures of water and granite or brine and salt for moderator or reflector materials were not studied. 
Table 8.. Some properties of the moderator and reflector materials

\begin{tabular}{|c|c|c|}
\hline $\begin{array}{l}\text { Moderator or } \\
\text { reflector } \\
\text { material }\end{array}$ & Chemical composition (weight percent) & Density $\left(\mathrm{g} / \mathrm{cm}^{3}\right)$ \\
\hline Water & Hydrogen (11.11), oxygen (88.89) & 1.00 \\
\hline Brine & $\begin{array}{l}\text { Hydrogen }(8.17) \text {, oxygen }(65.36), \\
\text { sodium }(10.42) \text {, chlorine }(16.06)^{a}\end{array}$ & 1.18 \\
\hline $\begin{array}{l}\text { Granite and } \\
\text { shale }\end{array}$ & $\begin{array}{l}\text { Oxygen }(52.02), \text { aluminum }(10.58), \\
\text { silicon }(37.40)\end{array}$ & 2.91 \\
\hline Salt & Sodium (39.34), chlorine (60.66) & 2.165 \\
\hline
\end{tabular}

There are five actinides abundant enough in nuclear waste to consider either separately or in combination as forming critical masses in waste repositories. These five actinides are uranium, neptunium, plutonium, americium, and curium. Critical mass calculations were made for the oxide state of each of these actinides and for a mixture of the five actinide oxides.

The calculated critical mass is dependent on the isotopic composition of the actinide. Isotopic compositions vary from one waste type to another and also change with time due to decay of the waste. As a result, five waste types and five waste ages were considered in this study.

CRTTICAL MASS COMPUTATIONAL MODEL

A computational model was developed to perform the criticality calculations and to produce plots of critical mass versus actinide compound concentration in moderator. The discrete-ordinate code XSDRNPM 6 was used to check computational model development. Use of conventional 
computer codes to perform the survey calculations was abandoned early in the study because conventional computer codes are programmed to perform one criticality search (a search on the radius until the multiplication factor is unity) at a time. It was estimated that approximately 4000 search calculations would be required to complete the survey. The data manipulation for input and output of conventional computer codes would have been unwieldy.

The computational model was developed to perform progressive radial search calculations until a curve of critical mass versus actinide compound concentration in mixture was generated. The model was programmed to be fast and efficient. The computational model uses a discreteordinates approximation to neutron transport theory and treats six neutron groups and spherical geometry. Little input is required and output consists of tables and curves of actinide, compound concentration in moderator versus critical mass and critical radius. More details on the computational model are presented in Appendix 1.

Most of the neutron cross sections used by the computational model were taken from a 218-neutron-group cross-section library ${ }^{7}$ developed for use in criticality calculations from ENDF/B-IV ${ }^{8}$ cross section data. The cross sections for $242 \mathrm{~m} \mathrm{Am},{ }^{242} \mathrm{Cm}, 244 \mathrm{Cm},{ }^{245} \mathrm{Cm}$, and ${ }^{246} \mathrm{Cm}$ were processed trom a preliminary ENDF/B-V Library because cross section data for these nuclides were not in ENDF/B-IV. The 218-group cross sections were collapsed to six-group sets using weighting spectra for water and brine mixtures.

Critical masses calculated with the computational model using the six-group $E N D F / b$ bàsed cross sections were checked àgainst experimental values and against more detailed calculated values. Critical radius and critical maes curves for eqveral of the test cases are given in Figs. 1-12. These test cases are: ${ }^{235} \mathrm{U},{ }^{239} \mathrm{Pu},{ }^{239} \mathrm{Pu}(0.90)+240 \mathrm{Pu}(0.10)$, $239 \mathrm{Pu}(0.80)+240 \mathrm{Pu}(0.20)$ in water, and ${ }^{239} \mathrm{Pu}$ and $\mathrm{PuO}_{2}\left[{ }^{238} \mathrm{Pu}(0.0195)+\right.$ $2{ }^{39} \mathrm{Pu}(0.4979)+240 \mathrm{Pu}(0.2138)+241 \mathrm{Pu}(0.1086)+242 \mathrm{Pu}(0.0420)+0$ $(0.118)]$ in brine. The calculated critical masses in these test cases were from $30 \%$ less to $10 \%$ greater than experimental values or more detailed calculated values. 


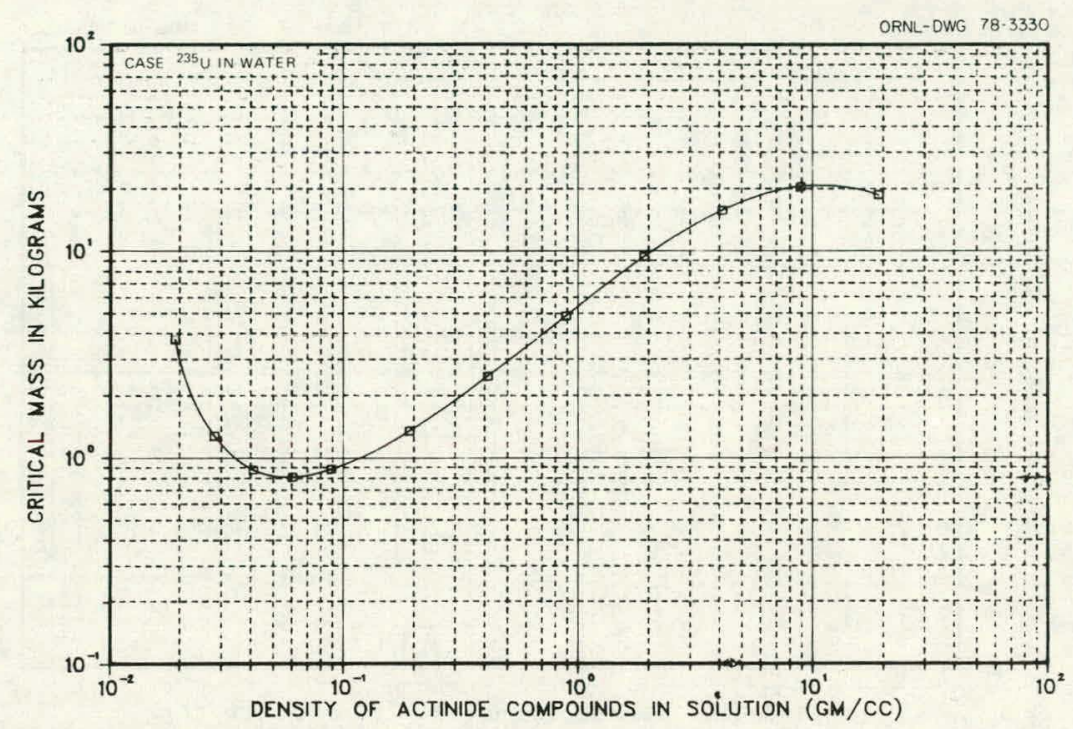

Fig. 1. Calculated critical mass plot of ${ }^{235} \mathrm{U}$ in water.

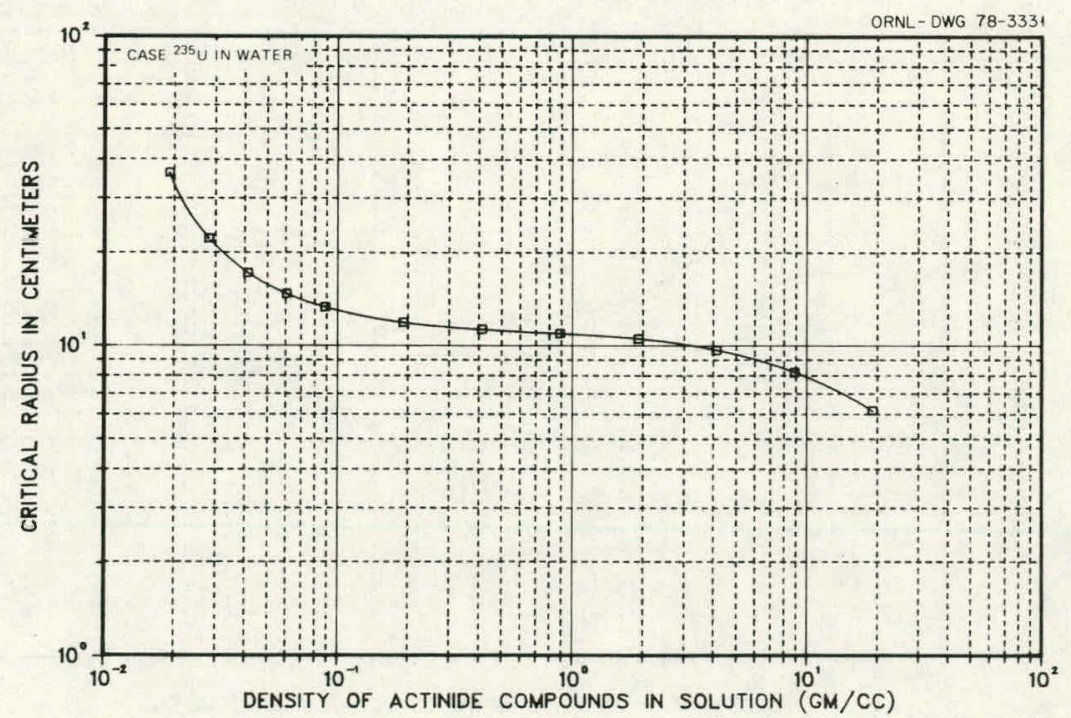

Fig. 2. Calculated critical radius plot of ${ }^{235} \mathrm{U}$ in water. 


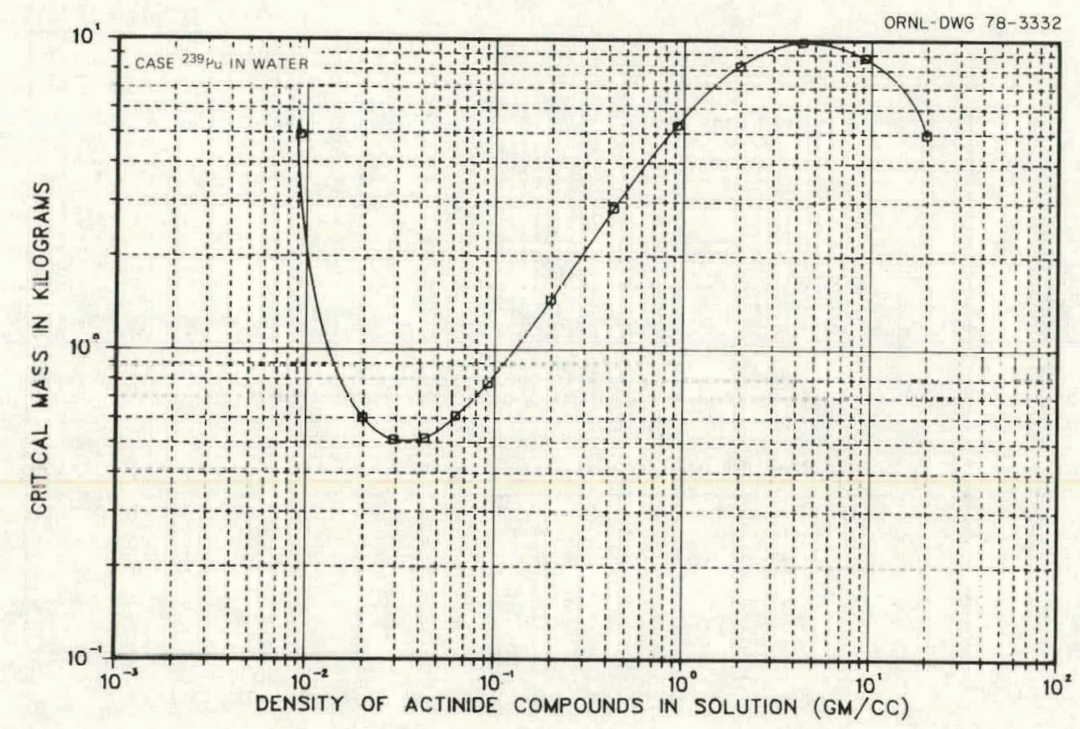

Fig. 3. Calculated critical mass plot of ${ }^{239} \mathrm{Pu}$ in water.

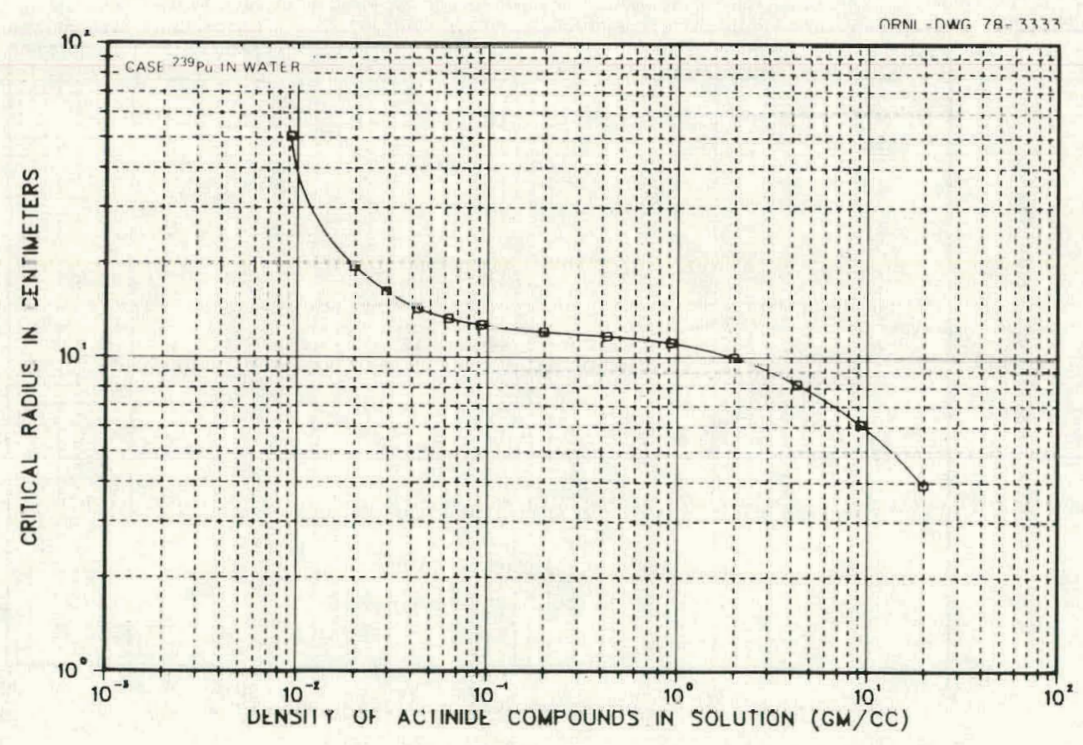

Fig. 4. Calculated critical radius plot of ${ }^{239} \mathrm{Pu}$ in water. 


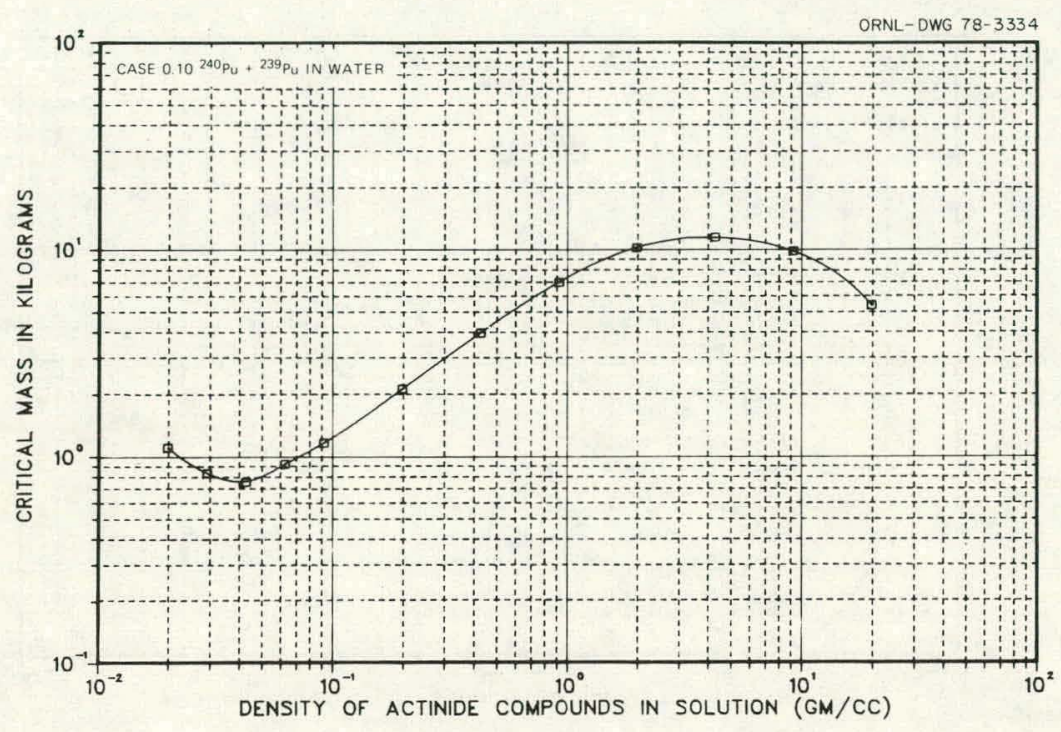

Fig. 5. Calculated critical mass plot of ${ }^{240} \mathrm{Pu}+{ }^{239} \mathrm{Pu}$ in water.

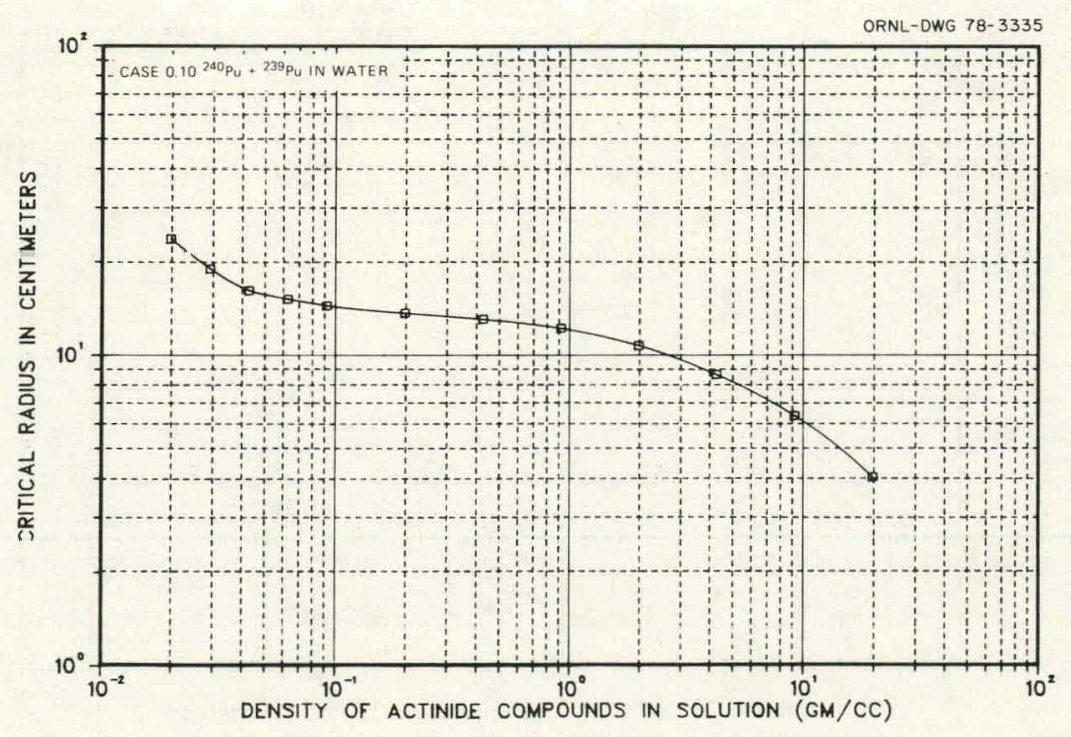

Fig. 6. Calculated critical radius plot of ${ }^{240} \mathrm{Pu}+{ }^{239} \mathrm{Pu}$ in water. 


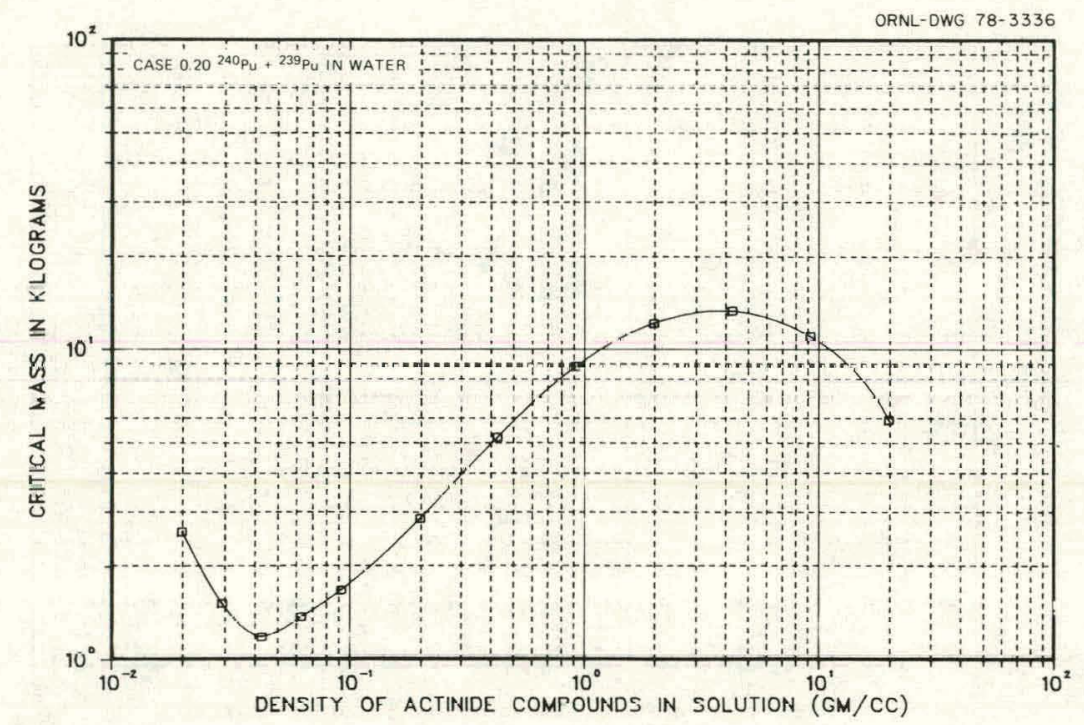

Fig. 7. Calculated critical mass plot of ${ }^{240} \mathrm{Pu}+{ }^{239} \mathrm{Pu}$ in water.

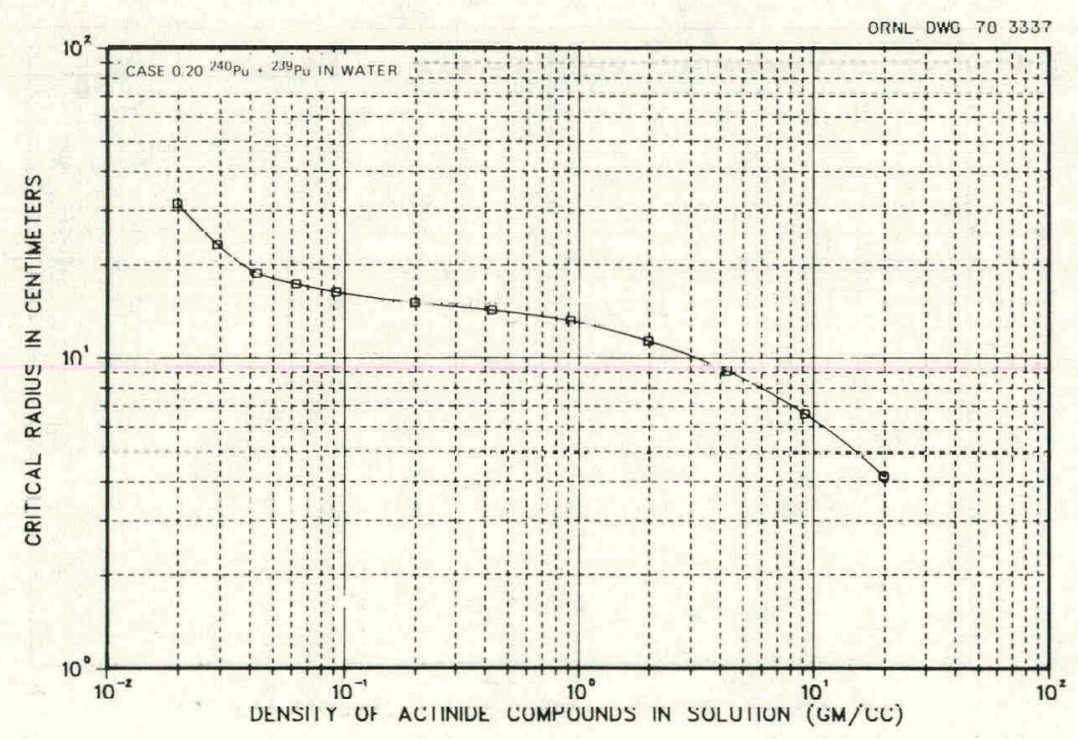

Fig. 8. Calculated critical radius plot of ${ }^{240} \mathrm{Pu}+{ }^{239} \mathrm{Pu}$ in water. 


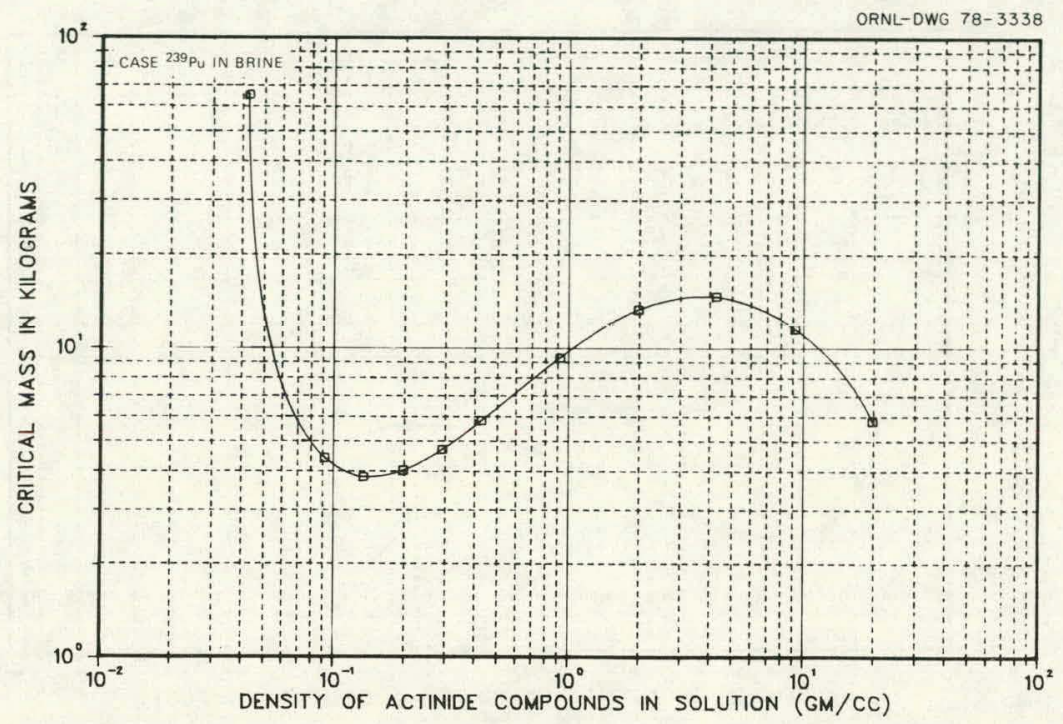

Fig. 9. Calculated critical mass plot of ${ }^{239} \mathrm{Pu}$ in brine.

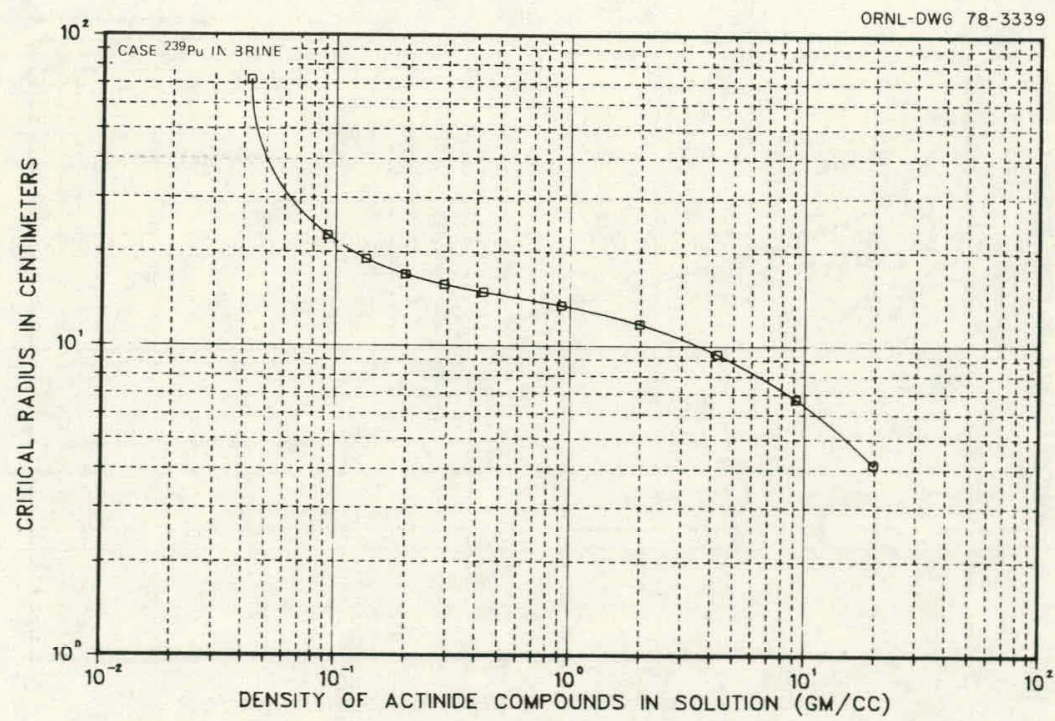

Fig. 10. Calculated critical radius plot of ${ }^{239} \mathrm{Pu}$ in brine. 


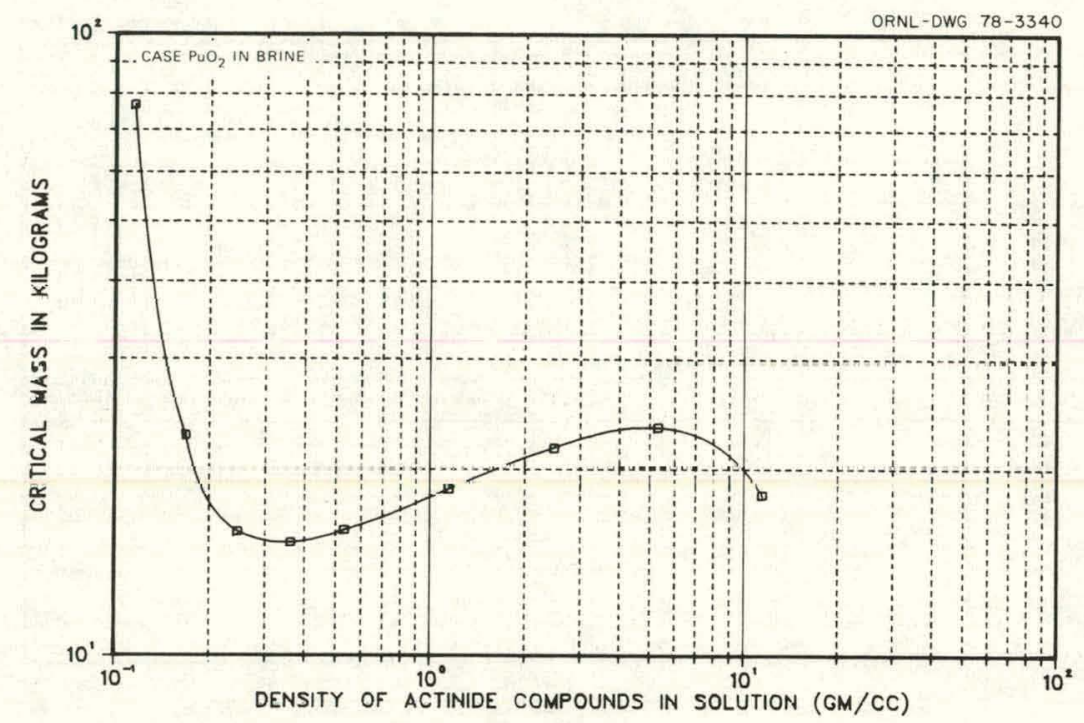

Fig. 11. Calculated critical mass plot of $\mathrm{PuO}_{2}$ in brine.

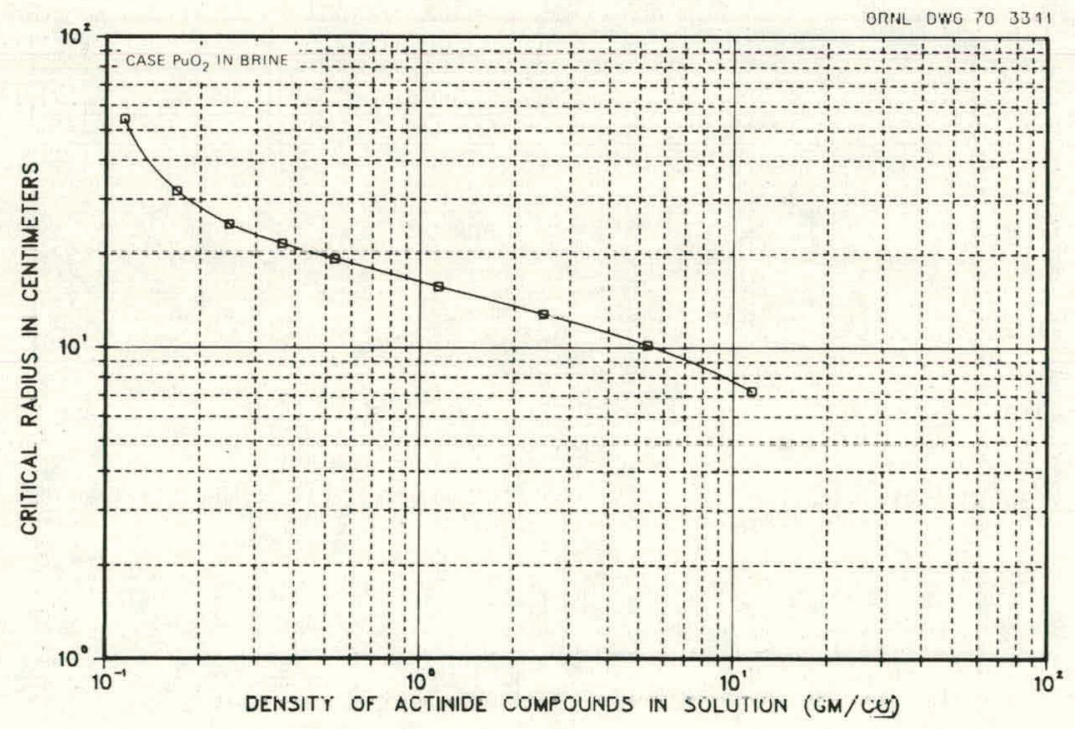

Fig. 12. Calculated critical radius plot of $\mathrm{PuO}_{2}$ in brine. 
The primary accuracy limitation of the critical mass calculational model is the lack of detail in the six-group cross-section structure. The six-group energy boundaries are given in Table 9. To obtain better accuracy a finer group structure is necessary but computational time increases rapidly with number of groups.

Table 9. Six-group neutron energy group structure

\begin{tabular}{ccc}
\hline Group number & Upper energy (ev) & Lower energy (ev) \\
\hline 1 & $2.00 \times 10^{7}$ & $1.85 \times 10^{6}$ \\
2 & $1.85 \times 10^{6}$ & $1.00 \times 10^{5}$ \\
3 & $1.00 \times 10^{5}$ & $5.5 \times 10^{2}$ \\
4 & $5.5 \times 10^{2}$ & 3.05 \\
5 & $3.05 \times 10^{-1}$ \\
6 & $1.25 \times 10^{-1}$ & $1.25 \times 1.00 \times 10^{-5}$ \\
\hline
\end{tabular}

Critical masses calculated with these ENDF/B-IV and ENDF/B-V cross sections may differ from critical masses calculated using other cross section sets or previous ENDF/B cross section libraries. This is due to basic differences in the cross section data. Several metal-water mixture calculations were made to compare with critical mass calculational results given in Ref. 9. The results of the calculations are given in Table 10. Critical mass plots for several of the calculations are given in Figs. 13-19. Generally, the agreement between minimum critical masses is within $10 \%$ except for ${ }^{244} \mathrm{Cm},{ }^{241} \mathrm{Am},{ }^{237} \mathrm{~Np}$, and ${ }^{240} \mathrm{Pu}$. For these nuclides, the calculated minimum critical masses differ by a factor of $1.5,1.6,2.2$, and 7.0 , respectively. These results indicate basic differences between the cross section sets used. In all cases, the minimum critical masses calculated with the six-group computational model were less than those of Ref. 9 .

\section{CALCULATIONAL RESULTS}

Over 400 different cases were calculated in the survey study, Each actinide compound of a specific isotopic composition mixed with a 
Table 10. Metal-water critical mass calculational results and comparison with values given in reference 9

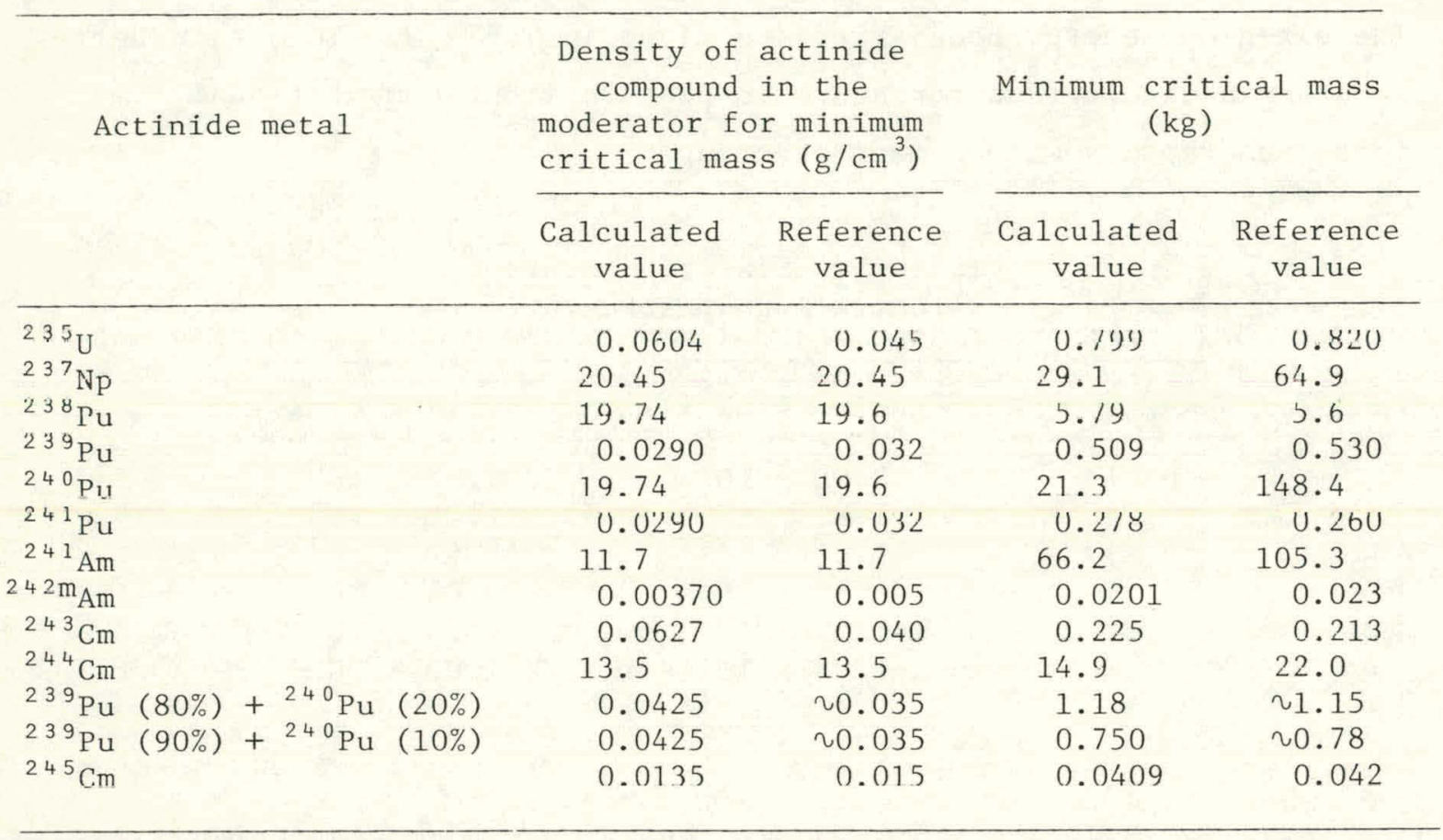

Note: Reflector and moderator materials were both watcr. Thickness of the reflector was $20 \mathrm{~cm}$.

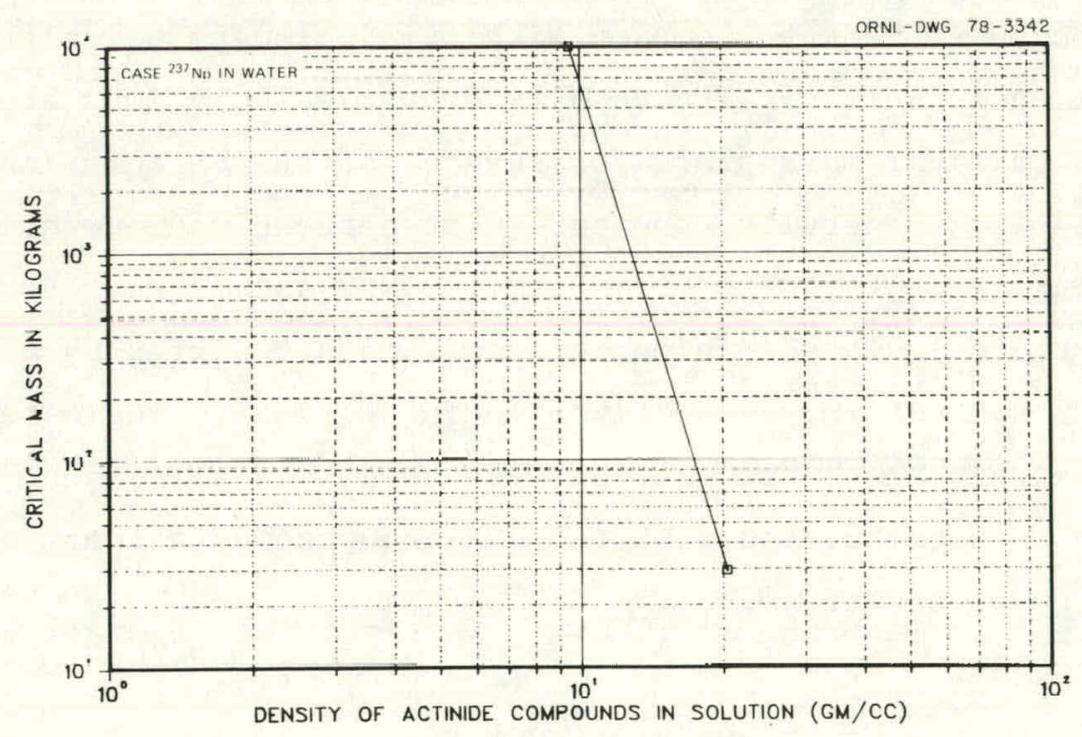

Fig. 13. Calculated critical mass plot of ${ }^{237} \mathrm{~Np}$ in water. 


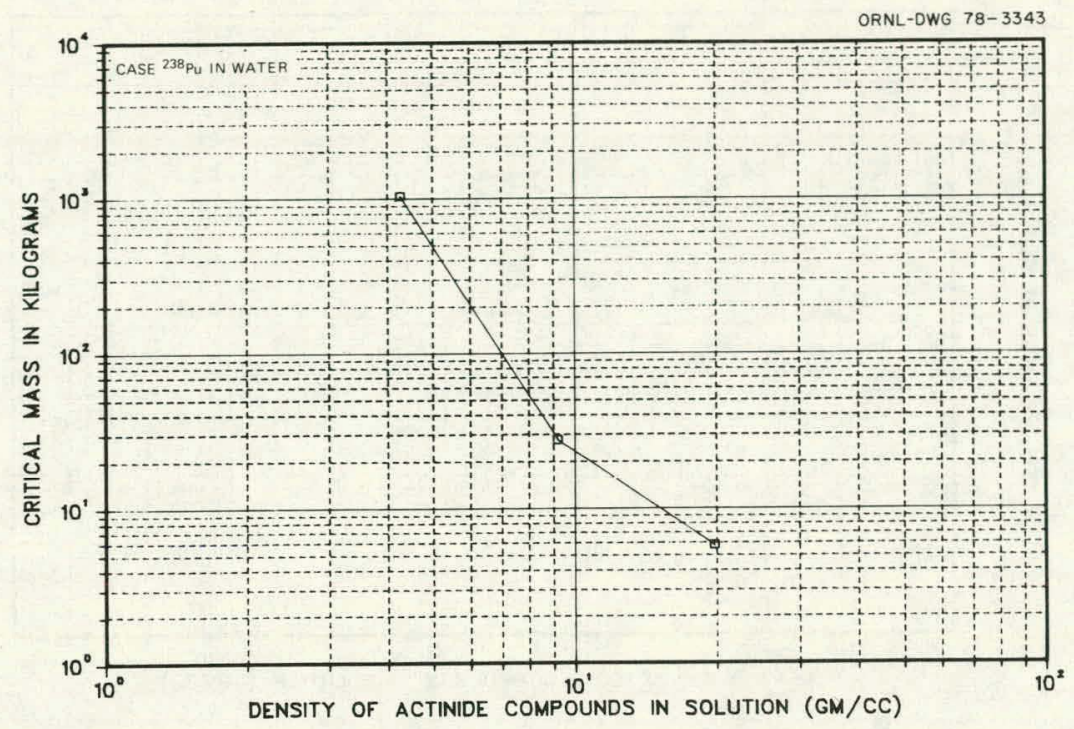

Fig. 14. Calculated critical mass plot of ${ }^{238} \mathrm{Pu}$ in water.

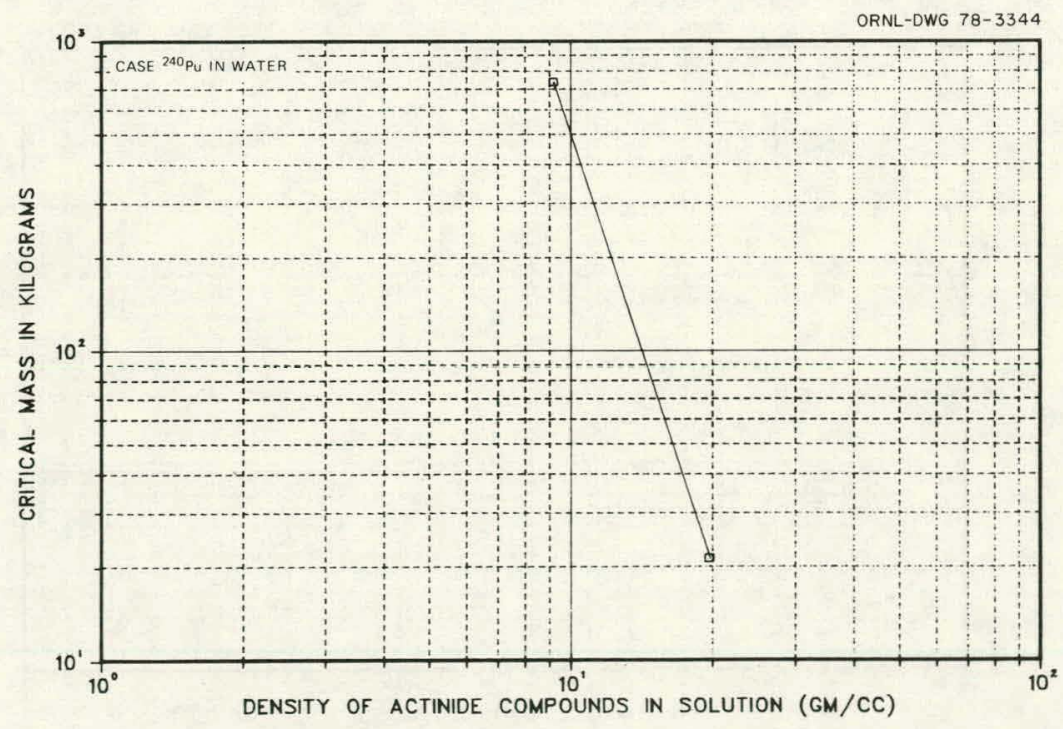

Fig. 15. Calculated critical mass plot of ${ }^{240} \mathrm{Pu}$ in water. 


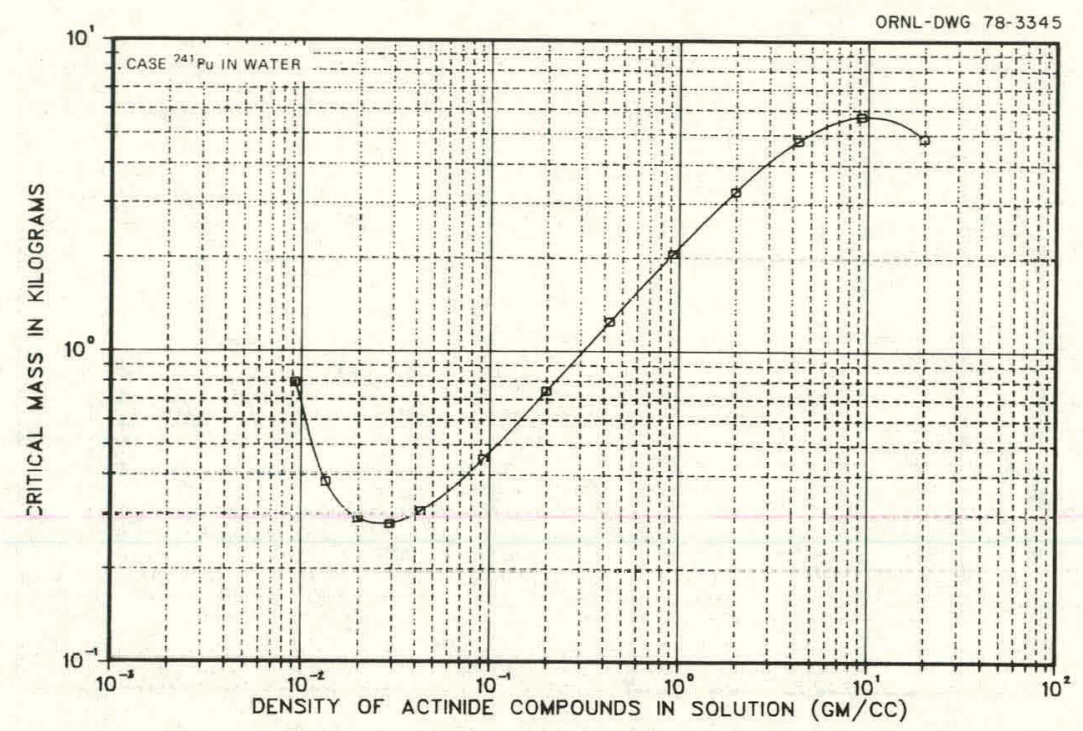

Fig. 16. Calculated critical mass plot of ${ }^{241} \mathrm{Pu}$ in water.

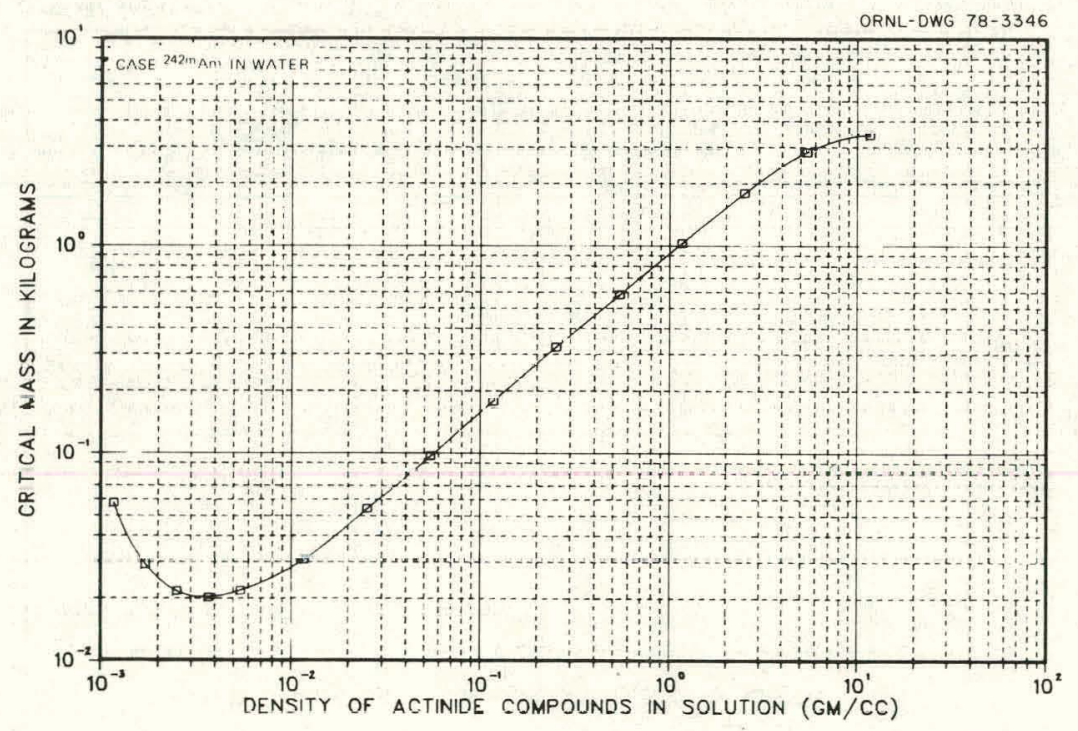

Fig. 17. Calculated critical mass plot of $242 \mathrm{~m} A m$ in water. 


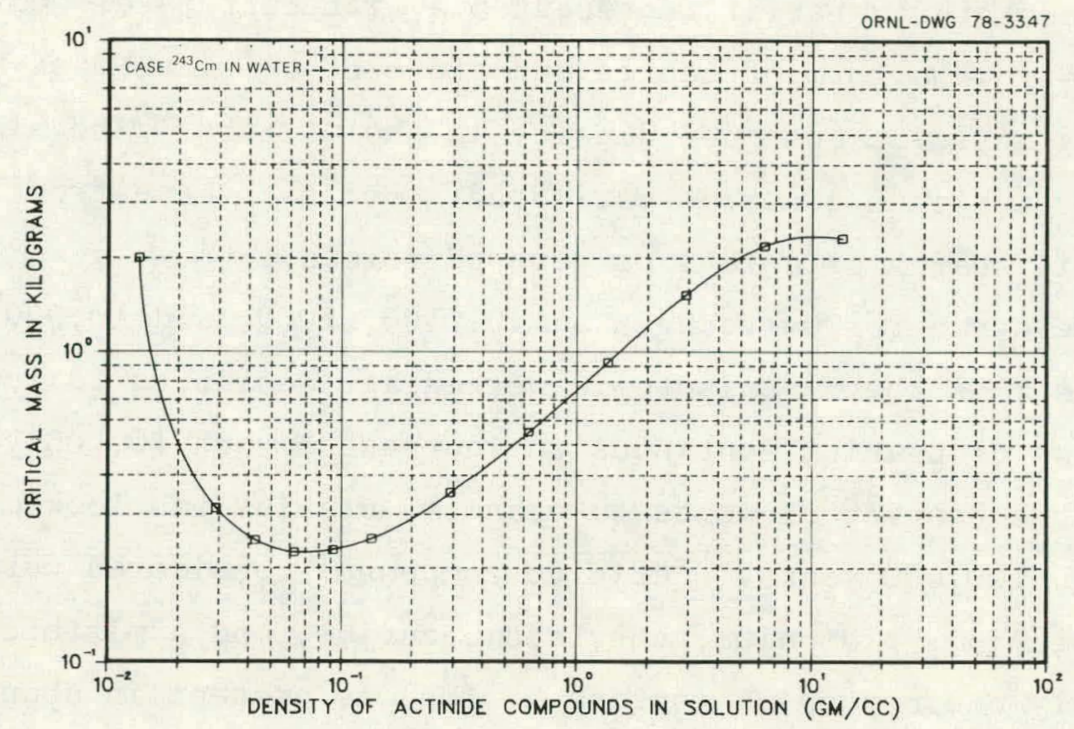

Fig. 18. Calculated critical mass plot of $2{ }^{24} \mathrm{Cm}$ in water.

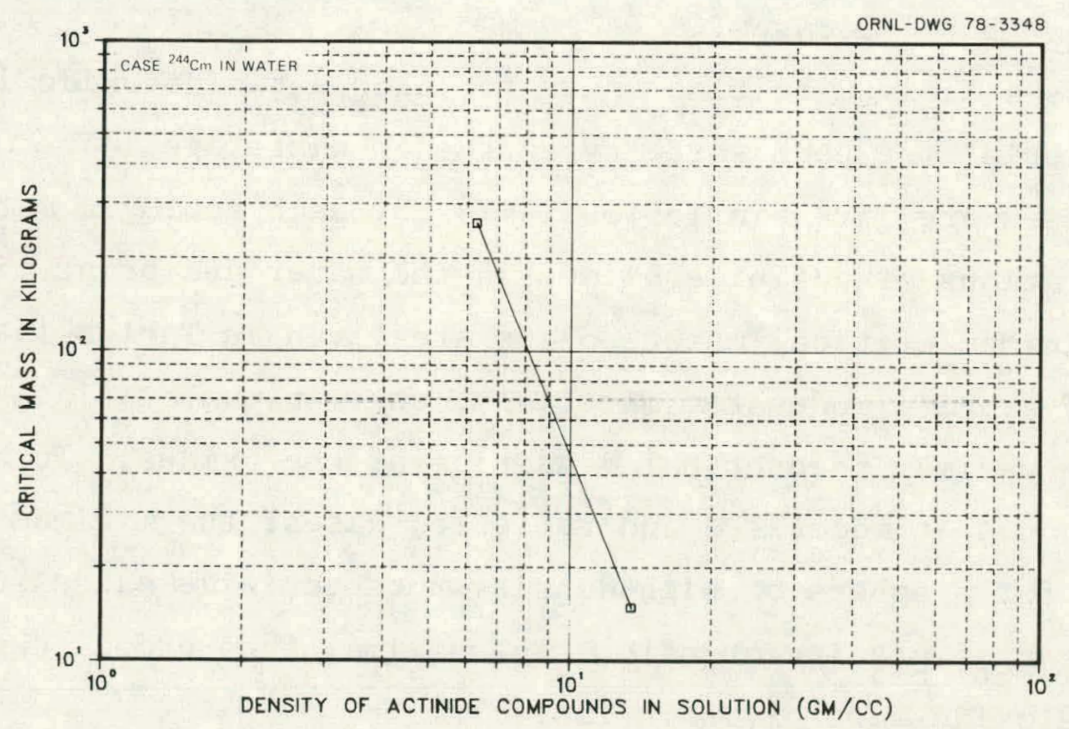

Fig. 19. Calculated critical mass plot of ${ }^{244} \mathrm{Cm}$ in water. 
particular moderator material represented a different case. Output from each case was in the form of tables and plots of critical mass and critical radius versus actinide compound density in the mixture. The minimum critical mass for each case was estimated. For each case from 1 to 15 critical radii search calculations were performed.

Cases were run for waste ages of 10,100, 1000, and 10,000 years for a11 actinides. As the ${ }^{235} \mathrm{U}$ isotopic percentage continues to increase and the total mass of uranium continues to increase beyond 10,000 years due to decay of the heavier elements to uranium, uranium was looked at also for an age of 100,000 years. Actinide compounds considered were oxides of uranium, neptunium, plutonium, americium, curium, and a mixture of these five. As only one neptunium isotope, ${ }^{237} \mathrm{~Np}$, is present in abundance, only four neptunium oxide calculations were required; one for each moderator material. (The neptunium isotopic composition does not change with waste type or waste age.) The reflector material was chosen to be identical to the moderator material and four materials were considered: water, brine, granite, and salt. Combinations of these variables result in $4 \times 5 \times 4 \times 5=400$ cases.

There is a minimum critical mass for each actinide oxide in each geologic material for each waste type of each waste age. The minimum critical masses are given in Tables 11-14 for each geologic material. The concentrations of actinide oxides in the water and brine mixtures at which the minimum critical masses occur are given in Tables 15 and 16 . For salt and granite moderator materials, the minimum critical masses occur at the maximum theoretical densities of the uxiles. In other words, for granite or salt moderated and rellected cases, the minimum critical mass occurs for a sphere of high-density pure actinide oxide surrounded by a reflector of graule or sa1t. The massimum theoretical iensities of the actinide oxides are given in Table 17.

In Tables 18-21, the maximum number of critical masses per waste container for each of the four moderator materials are presented for each waste type and waste age. These tabulated values were obtained by dividing the masses of actinide oxide per waste container given in Table 7 by the minimum critical masses given in Tables $11-14$. 
Table 11. Calculated minimum critical masses of actinide oxides moderated and reflected by water

\begin{tabular}{|c|c|c|c|c|c|c|}
\hline \multirow{3}{*}{ Actinide } & \multirow{3}{*}{$\begin{array}{c}\text { Age } \\
\text { (years) }\end{array}$} & \multicolumn{5}{|c|}{ Minimum rritical mass of oxide (kg) } \\
\hline & & \multicolumn{5}{|c|}{ Nuclear waste type } \\
\hline & & 1 & 2 & 3 & 4 & 5 \\
\hline Uranium & $\begin{array}{r}10 \\
100 \\
1,000 \\
10,000 \\
100,000\end{array}$ & $\begin{array}{l}\mathrm{N}^{a} \\
\mathrm{~N} \\
\mathrm{~N} \\
\mathrm{~N} \\
\mathrm{~N}\end{array}$ & $\begin{array}{l}\mathrm{N} \\
\mathrm{N} \\
\mathrm{N} \\
\mathrm{N} \\
\mathrm{N}\end{array}$ & $\begin{array}{c}\mathrm{N} \\
\mathrm{N} \\
\mathrm{N} \\
307.2 \\
67.5\end{array}$ & $\begin{array}{c}N \\
N \\
523.3 \\
9.02 \\
2.62\end{array}$ & $\begin{array}{c}N \\
N \\
N \\
N \\
17.9\end{array}$ \\
\hline Neptunium & Any age & 90.7 & 90.7 & 90.7 & 90.7 & 90.7 \\
\hline Plutonium & $\begin{array}{r}10 \\
100 \\
1,000 \\
10,000\end{array}$ & $\begin{array}{l}1.84 \\
2.37 \\
2.12 \\
1.27\end{array}$ & $\begin{array}{l}4.13 \\
21.3 \\
11.3 \\
1.12\end{array}$ & $\begin{array}{c}28.4 \\
41.5 \\
32.0 \\
1.11\end{array}$ & $\begin{array}{l}1.88 \\
2.39 \\
2.08 \\
1.20\end{array}$ & $\begin{array}{c}24.5 \\
36.7 \\
29.5 \\
1.61\end{array}$ \\
\hline Americium & $\begin{array}{r}10 \\
100 \\
1,000 \\
10,000\end{array}$ & $\begin{array}{r}69.0 \\
65.9 \\
74.4 \\
150.3\end{array}$ & $\begin{array}{r}85.5 \\
88.4 \\
119.9 \\
150.3\end{array}$ & $\begin{array}{r}84.4 \\
91.7 \\
132.5 \\
245.5\end{array}$ & $\begin{array}{r}68.5 \\
65: 6 \\
73.5 \\
150.3\end{array}$ & $\begin{array}{r}84.7 \\
91.2 \\
130.8 \\
149.8\end{array}$ \\
\hline Curium & $\begin{array}{r}10 \\
100 \\
1,000 \\
10,000\end{array}$ & $\begin{array}{l}6.84 \\
0.160 \\
0.0515 \\
0.0495\end{array}$ & $\begin{array}{l}6.83 \\
0.160 \\
0.0515 \\
0.0495\end{array}$ & $\begin{array}{l}0.325 \\
0.0588 \\
0.0512 \\
0.0493\end{array}$ & $\begin{array}{l}7.09 \\
0.163 \\
0.0513 \\
0.0495\end{array}$ & $\begin{array}{l}0.347 \\
0.0593 \\
0.0512 \\
0.0492\end{array}$ \\
\hline $\begin{array}{l}\text { Mixture of five } \\
\text { actinides }\end{array}$ & $\begin{array}{r}10 \\
100 \\
1,000 \\
10,000\end{array}$ & $\begin{array}{l}N \\
N \\
N \\
N\end{array}$ & $\begin{array}{l}3931.2 \\
4256.1 \\
4242.7 \\
3390.5\end{array}$ & $\begin{array}{l}267.6 \\
340.8 \\
361.2 \\
237.4\end{array}$ & $\begin{array}{c}5.41 \\
16.2 \\
8.52 \\
4.56\end{array}$ & $\begin{array}{l}784.6 \\
950.7 \\
990.3 \\
680.8\end{array}$ \\
\hline
\end{tabular}

$a_{\mathrm{N}}$ means that criticalicy cannot be achieved for a one-meter radius spherical mass of maximum denisity material.

Table 12. Calculated minimum critical masses of actinide oxides moderated and reflected by brine

\begin{tabular}{|c|c|c|c|c|c|c|}
\hline \multirow{3}{*}{ Actinide } & \multirow{3}{*}{$\begin{array}{c}\text { Age } \\
\text { (years) }\end{array}$} & \multicolumn{5}{|c|}{ Minimum critical mass of oxide (kg) } \\
\hline & & \multicolumn{5}{|c|}{ Nuclear waste type } \\
\hline & & 1 & 2 & 3 & 4 & 5 \\
\hline Uranium & $\begin{array}{r}10 \\
100 \\
1,00 n \\
10,000 \\
100,000\end{array}$ & $\begin{array}{l}\mathrm{N}^{a} \\
\mathrm{~N} \\
\mathrm{~N} \\
\mathrm{~N} \\
\mathrm{~N}\end{array}$ & $\begin{array}{l}\mathrm{N} \\
\mathrm{N} \\
\mathrm{M} \\
\mathrm{N} \\
\mathrm{N}\end{array}$ & $\begin{array}{c}\mathrm{N} \\
\mathrm{N} \\
\mathrm{N} \\
\mathrm{N} \\
112.5\end{array}$ & $\begin{array}{r}N \\
N \\
10323.0 \\
180.1 \\
34.4\end{array}$ & $\begin{array}{r}\mathrm{N} \\
\mathrm{N} \\
\mathrm{N} \\
\mathrm{N} \\
403.1\end{array}$ \\
\hline Neptunium & Any age & 89.8 & 89.8 & 89.8 & 89.8 & 89.8 \\
\hline Plutonium & $\begin{array}{r}10 \\
100 \\
1,000 \\
10,000\end{array}$ & $\begin{array}{l}16.4 \\
19.3 \\
19.1 \\
12.3\end{array}$ & $\begin{array}{l}20.0 \\
24.9 \\
23.1 \\
10.8\end{array}$ & $\begin{array}{l}31.6 \\
43.6 \\
35.6 \\
17.4\end{array}$ & $\begin{array}{l}16.6 \\
19.1 \\
18.9 \\
12.0\end{array}$ & $\begin{array}{l}27.9 \\
39.6 \\
33.1 \\
15.9\end{array}$ \\
\hline Americium & $\begin{array}{r}10 \\
100 \\
1,000 \\
10,000\end{array}$ & $\begin{array}{r}71.7 \\
68.3 \\
77.2 \\
158.2\end{array}$ & $\begin{array}{r}89.7 \\
92.7 \\
125.7 \\
158.1\end{array}$ & $\begin{array}{r}92.0 \\
98.9 \\
139.4 \\
256.1\end{array}$ & $\begin{array}{r}71.2 \\
68.0 \\
76.3 \\
158.1\end{array}$ & $\begin{array}{r}91.7 \\
98.0 \\
137.3 \\
157.6\end{array}$ \\
\hline Curium & $\begin{array}{r}10 \\
100 \\
1,000 \\
10,000\end{array}$ & $\begin{array}{l}15.0 \\
1.58 \\
0.471 \\
0.451\end{array}$ & $\begin{array}{l}15.0 \\
1.50 \\
0.471 \\
0.451\end{array}$ & $\begin{array}{l}3.35 \\
0.351 \\
0.461 \\
0.451\end{array}$ & $\begin{array}{l}15.0 \\
1.01 \\
0.469 \\
0.450\end{array}$ & $\begin{array}{l}3.56 \\
0.336 \\
0.467 \\
0.450\end{array}$ \\
\hline Mixture of five & $\begin{array}{r}10 \\
100 \\
1,000 \\
10,000\end{array}$ & $\begin{array}{l}N \\
N \\
N \\
N\end{array}$ & $\begin{array}{l}4760.3 \\
5181.1 \\
5232.9 \\
4216.9\end{array}$ & $\begin{array}{l}304.8 \\
381.9 \\
407.7 \\
286.7\end{array}$ & $\begin{array}{l}43.3 \\
50.9 \\
53.6 \\
70.5\end{array}$ & $\begin{array}{r}901.1 \\
1084.0 \\
1139.6 \\
818.6\end{array}$ \\
\hline
\end{tabular}

$a_{N}$ means that criticality cannot be achieved for a one-meter radius spherical mass of maximum denșiţ material. 
Table 13. Calculated minimum critical masses of actinide oxides moderated and reflected by granite

\begin{tabular}{|c|c|c|c|c|c|c|}
\hline \multirow{3}{*}{ Actinide } & \multirow{3}{*}{$\begin{array}{c}\text { Age } \\
\text { (years) }\end{array}$} & \multicolumn{5}{|c|}{ Minimum critical mass of oxide $(\mathrm{kg})$} \\
\hline & & \multicolumn{5}{|c|}{ Nuclear waste type } \\
\hline & & 1 & 2 & 3 & 4 & 5 \\
\hline \multirow[t]{5}{*}{ Uranium } & 10 & $N^{a}$ & $\mathbf{N}$ & N & $\mathrm{N}$ & $\mathrm{N}$ \\
\hline & 100 & $\mathbf{N}$ & $\mathrm{N}$ & $\mathrm{N}$ & $\mathrm{N}$ & $\mathrm{N}$ \\
\hline & 1,000 & $\mathbf{N}$ & $\mathrm{N}$ & $\mathrm{N}$ & 5353.4 & $\mathrm{~N}$ \\
\hline & 10,000 & $\mathrm{~N}$ & $\mathrm{~N}$ & 23609.0 & 344.5 & $\mathrm{~N}$ \\
\hline & 100,000 & $\mathrm{~N}$ & N & 281.1 & 111.1 & 787.9 \\
\hline Neptunium & Any age & 45.0 & 45.0 & 45.0 & 45.0 & 45.0 \\
\hline \multirow[t]{4}{*}{ Plutnnium } & 10 & 12.2 & 13,0 & 18.6 & 12.1 & 17.0 \\
\hline & 100 & 12.5 & 15.4 & 23.4 & 13.4 & ji. 8 \\
\hline & 1,000 & 12.4 & 14.5 & 20.3 & 12.3 & 19.3 \\
\hline & 10,000 & 11.6 & 11.1 & 14.5 & 11.5 & 11.8 \\
\hline \multirow[t]{4}{*}{ Americium } & 10 & 30.1 & 44.0 & 40.6 & 35.0 & 46.3 \\
\hline & 100 & 34.5 & 45.9 & 49.7 & 34.3 & 49.1 \\
\hline & 1,000 & 38.7 & 61.8 & 68.8 & 38.2 & 67.9 \\
\hline & in. nnก & 78.9 & 79.0 & 40.2. & 18,9 & 78.6 \\
\hline \multirow[t]{4}{*}{ Curium } & 10 & 10.3 & 10.3 & 7.81 & 10.3 & 7.91 \\
\hline & 100 & 6.19 & 6.19 & 3.53 & 6.22 & 3.58 \\
\hline & 1,000 & 3.17 & $3.1 \%$ & 3.15 & 3.16 & 3.15 \\
\hline & 10,000 & 3.03 & 3.03 & 3.61 & 3.03 & 3.02 \\
\hline Mixture o[ & 10 & $\mathbf{N}$ & 2444.4 & 151.9 & 26.2 & 457.4 \\
\hline \multirow[t]{3}{*}{ five actinides } & 100 & $\mathrm{~N}$ & 2648.4 & 185.6 & 29.4 & 549.9 \\
\hline & 1,000 & $\mathrm{~N}$ & 2669.9 & 197.4 & 31.4 & 580.1 \\
\hline & 10,000 & $\mathrm{~N}$ & 2204.4 & 151.4 & 41.2 & 432.4 \\
\hline
\end{tabular}

$\dot{u}_{\mathrm{N}}$ means that cricicality cannot be achieved for a one-meter radius spherical mass of maximum denisty material.

Table 14. Calculated minimum critical masses of actinide oxides moderated and reflected by salc

\begin{tabular}{|c|c|c|c|c|c|c|}
\hline \multirow{3}{*}{ Actinide } & \multirow{3}{*}{$\begin{array}{c}\mathrm{Age} \\
\text { (years) }\end{array}$} & \multicolumn{5}{|c|}{ Minimum oribical mase of nxidp (kg) } \\
\hline & & \multicolumn{5}{|c|}{ Nuclear waste type } \\
\hline & & 1 & 2 & 3 & 4 & $b$ \\
\hline \multirow[t]{5}{*}{ Uranium } & 10 & $\mathrm{~N}^{\mathrm{a}}$ & $\mathrm{N}$ & $\mathrm{N}$ & $\mathrm{N}$ & $\mathrm{N}$ \\
\hline & 100 & $\mathrm{~N}$ & $\mathrm{~N}$ & $N$ & $\mathrm{~N}$ & $\mathrm{~N}$ \\
\hline & 1, UOU & $\mathrm{N}$ & $\mathrm{N}$ & is & 9145.0 & $\mathrm{n}$ \\
\hline & 10,000 & $\mathrm{~N}$ & $\mathrm{~N}$ & $\mathrm{~N}$ & 649.2 & $\mathrm{~N}$ \\
\hline & 100,000 & $\mathrm{~N}$ & $\mathrm{~N}$ & 657.2 & 192.8 & 2225.7 \\
\hline Neprunium & Any age & 73.9 & 73.9 & 73.9 & 73.9 & 73.9 \\
\hline \multirow[t]{4}{*}{ Pluconium } & 10 & 21.1 & 22.6 & 32.1 & 20.9 & 29.4 \\
\hline & 100 & 21.7 & 26.7 & 40.4 & 21.5 & 37.7 \\
\hline & 1.000 & 21.5 & 25.3 & 35.2 & 21.3 & 33.4 \\
\hline & 10,000 & 20.1 & 19.1 & 29.4 & 19.9 & 20.3 \\
\hline \multirow[t]{4}{*}{ Americium } & 10 & bU.y & $\gamma_{0.1}$ & 80.0 & 60.4 & 79.4 \\
\hline & 100 & 57.9 & 78.3 & 85.1 & 57.7 & 84.1 \\
\hline & 1,000 & 65.0 & 105.0 & 116.8 & 64.2 & 115.2 \\
\hline & 10,000 & 133.1 & 133.1 & 172.3 & 133.1 & 132.6 \\
\hline \multirow[t]{4}{*}{ Curium } & 10 & 17.0 & 17.0 & 13.1 & 17.0 & 13.2 \\
\hline & 100 & 10.2 & 10.2 & 5.60 & 10.3 & 5.64 \\
\hline & 1,000 & 4.95 & 4.95 & 4.90 & 4.92 & 4.91 \\
\hline & 10,000 & 4.72 & 4.72 & $4 . \%$ & 4.11 & 4.70 \\
\hline Mixture of & 10 & $\mathrm{~N}$ & 4066.2 & 264.3 & 45.9 & 769.1 \\
\hline \multirow[t]{3}{*}{ five actinides } & 100 & $\mathrm{~N}$ & 4427.8 & 326.1 & 51.3 & 919.8 \\
\hline & 1,000 & $\mathrm{~N}$ & 4481.1 & 348.8 & 55.1 & 970.4 \\
\hline & 10,000 & $\mathrm{~N}$ & 3657.4 & 264.4 & 72.9 & 730.0 \\
\hline
\end{tabular}

$a_{N}$ means that criticality cannot be achieved for a one-meter radius spherical mass of maximum density material. 
Table 15. Concentrations of actinide oxides in water for minimur critical mass

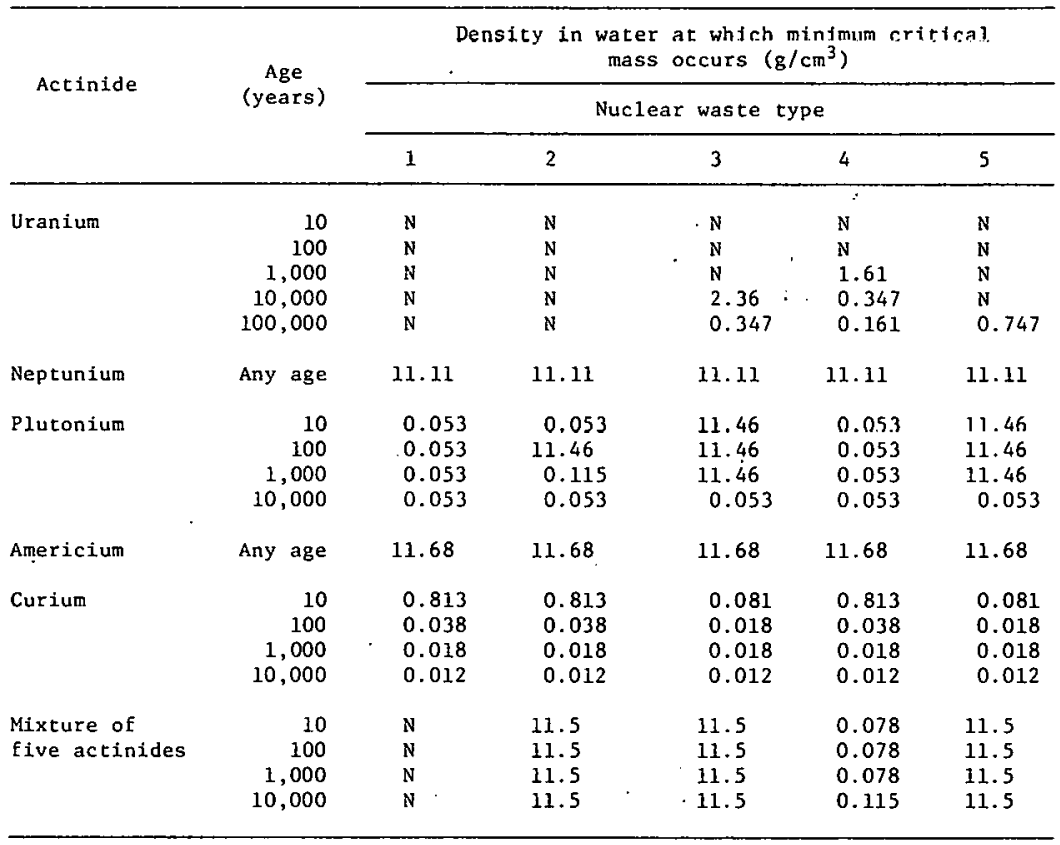

Table 16. Concentrations of actinide oxides in brine for minimum critical mass

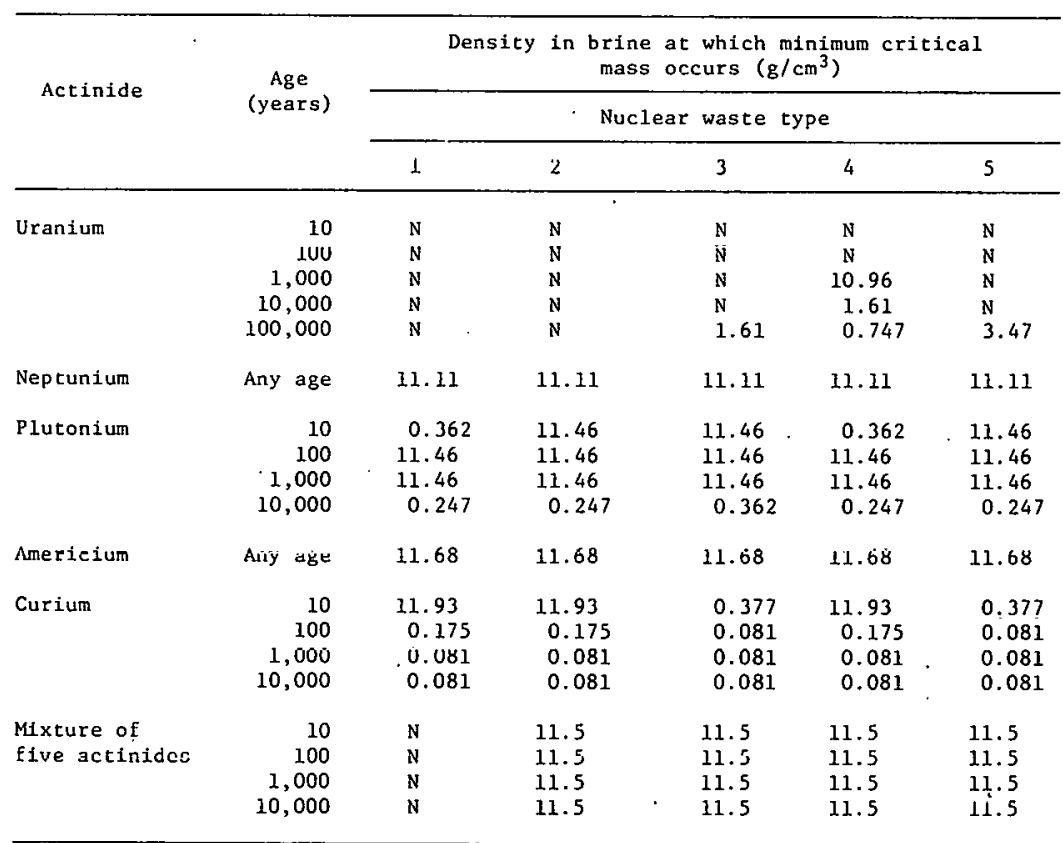


Table 17. Maximum densities of actinide oxides

\begin{tabular}{lc}
\hline $\begin{array}{c}\text { Actinide } \\
\text { oxide }\end{array}$ & $\begin{array}{c}\text { Maximum theoretical } \\
\text { density }\left(\mathrm{g} / \mathrm{cm}^{3}\right)\end{array}$ \\
\hline Uranium oxide & $10.96^{\mathrm{a}}$ \\
Neptunium oxide & $11.11^{\mathrm{a}}$ \\
Plutonium oxide & $11.46^{\mathrm{a}}$ \\
Americium oxide & $11.68^{\mathrm{a}}$ \\
Curium oxide & $11.93^{\mathrm{b}}$ \\
Mixture of five & $11.5^{\mathrm{c}}$ \\
actinide oxides & \\
\hline
\end{tabular}

a From CRC Handbook of Chemistri, and Phusicis, 58 th edition.

${ }^{b}$ Estimated based on extrapolation of densitics of uranium oxide, neptunium oxide, plutonium uxide, and americium oxide.

${ }^{c}$ Approximate average density.

Table 18. Maximum number of critical masses per waste container for water moderator and reflector

\begin{tabular}{|c|c|c|c|c|c|c|c|}
\hline \multirow{2}{*}{$\begin{array}{l}\text { Nuclear } \\
\text { waste } \\
\text { type }\end{array}$} & \multirow{2}{*}{$\begin{array}{c}\text { Age } \\
\text { (years) }\end{array}$} & \multicolumn{6}{|c|}{$\begin{array}{l}\text { Maximum number of critical masses per } \\
\text { container for each actinide oxide }\end{array}$} \\
\hline & & Utall iuIt & NeرLun i uII! & Plulultiuil & Aüitéiciun & Currium & $\begin{array}{l}\text { Mixture } \\
\text { of five } \\
\text { actinides }\end{array}$ \\
\hline 1 & in & ก & $0.0 \cap 27$ & 2.55 & 0.00146 & 0.0013 & 0 \\
\hline 1 & 100 & 0 & 0.0035 & 1.79 & 0.0097 & 0.0027 & 0 \\
\hline 1 & 1,000 & 0 & 0.0085 & 1.90 & 0.0025 & 0.0026 & 0 \\
\hline 1 & 10,000 & 0 & 0.0100 & 2.20 & 0.0001 & 0.0012 & 0 \\
\hline 1 & 100,000 & 0 & & & & & \\
\hline 2 & 10 & 0 & 0.0121 & 0.0306 & 0.0054 & 0.0059 & 0.0033 \\
\hline 2 & 100 & 0 & 0.0126 & $0.00 \% 2$ & 0.0044 & 0.0121 & 0.0031 \\
\hline 2 & 1,000 & 0 & 0.0143 & 0.0141 & 0.0021 & 0.0117 & 0.0031 \\
\hline 2 & 10,000 & $u$ & U. U14У & 0.1690 & 0.0006 & 0.0053 & 0.0039 \\
\hline 2 & 100,000 & 0 & & & & & \\
\hline 3 & 10 & 0 & 0.0046 & 0.0301 & 0.0019 & 4.13 & 0.0707 \\
\hline 3 & inn & $n$ & 0.0072 & 0.0451 & 0.0540 & 4.55 & 0.0554 \\
\hline 3 & 1,000 & 0 & 0.0203 & 0.0618 & 0.0260 & 4.17 & 0.0522 \\
\hline 3 & 10,000 & $U$ & $\dot{0} . \dot{0} 252$ & 1.393 & 0.0056 & 1.96 & 0.0791 \\
\hline 3 & 100,000 & 0.236 . & & & & & \\
\hline 4 & 10 & 0 & 0.0254 & 11.64 & 0.0201 & 0.0048 & 6.84 \\
\hline 4 & . 100 & . $\quad 0$ & 0.0291 & 8.25 & 0.0428 & 0.0100 & 2.28 \\
\hline 4 & 1,000 & 0.0247 & 0.0509 & 8.93 & 0.0109 & 0.0971 & 4.33 \\
\hline 4 & 10,000 & 2.07 & 0.0578 & 10.72 & 0.0005 & 0.0045 & 8.07 \\
\hline 4 & 100,000 & 11.30 & & & & & \\
\hline 5 & 10 & 0 & 0.0097 & 0.0151 & 0.0242 & 1.37 & 0.0192 \\
\hline 5 & 100 & 0 & 0.0108 & 0.0198 & 0.0213 & 1.52 & 0.0158 \\
\hline 5 & 1,000 & 0 & 0.0163 & 0.0260 & 0.0100 & 1.40 & 0.0151 \\
\hline 5 & 10,000 & 0 & 0.0183 & 0.5891 & 0.0034 & 0.657 & 0.0220 \\
\hline 5 & 100,000 & 0.731 & & & & & \\
\hline
\end{tabular}


Table 19. Maximum number of critical masses per waste container for brine moderator and reflector

\begin{tabular}{|c|c|c|c|c|c|c|c|}
\hline \multirow{2}{*}{$\begin{array}{l}\text { Nuclear } \\
\text { waste } \\
\text { type }\end{array}$} & \multirow{2}{*}{$\begin{array}{c}\text { Age } \\
\text { (years) }\end{array}$} & \multicolumn{6}{|c|}{$\begin{array}{c}\text { Maximum number of critical masses per } \\
\text { conldiner [or each actinide oxide }\end{array}$} \\
\hline & & Uranium & Neptunium & Plutonium & Americium & Curium & $\begin{array}{l}\text { Mixture } \\
\text { of five } \\
\text { actinides }\end{array}$ \\
\hline 1 & 10 & 0 & 0.0027 & 0.286 & 0.0044 & 0.0006 & 0 \\
\hline l & 100 & 0 & 0.0036 & 0.220 & 0.0093 & 0.0003 & 0 \\
\hline 1 & 1,000 & 0 & 0.0086 & 0.211. & 0.0024 & 0.0003 & 0 \\
\hline 1 & 10.000 & 0 & 0.01 .01 & 0.227 & 0.0001 & 0.0001 & 0 \\
\hline 1. & 100,000 & 0 & & & & & \\
\hline 2 & 10 & 0 & 0.0122 & 0.0063 & 0.0051 & 0.0027 & 0.0027 \\
\hline 2 & 100 & 0 & 0.0127 & 0.0062 & 0.0047 & 0.0012 & 0.0025 \\
\hline 2 & 1,000 & 0 & 0.0145 & 0.0069 & 0.0020 & 0.0013 & 0.0025 \\
\hline 2 & 10,000 & 0 & 0.0150 & 0.0175 & 0.0005 & 0.0006 & 0.0031 \\
\hline 2 & 100,000 & 0 & & & & & \\
\hline 3 & 10 & 0 & 0.0047 & 0.0270 & 0.0568 & 0.401 & 0.0620 \\
\hline 3 & 100 & 0 & 0.0073 & 0.0429 & 0.0501 & 0.485 & 0.0494 \\
\hline 3 & 1,000 & 0 & 0.0205 & 0.0515 & 0.0247 & 0.464 & 0.0462 \\
\hline 3 & 10,000 & 0 & 0.0255 & 0.1417 & 0.0053. & 0.214 & 0.0655 \\
\hline 3 & 100,000 & 0.141 & & & & & \\
\hline 4 & 10 & 0 & 0.0256 & 1.32 & 0.0194 & 0.0023 & 0.855 \\
\hline 4 & 100 & . 0 & 0.0294 & 1.03 & 0.0413 & 0.0010 & 0.727 \\
\hline 4 & 1,000 & 0.00 .13 & 0.0514 & 0.983 & 0.0105 & $0: 0011$ & 0.689 \\
\hline 4 & 10,000 & 0.1 .04 & 0.0584 & 1.07 & 0.0005 & 0.0005 & 0.522 \\
\hline 4 & 100,000 & 0.861 & & & & & \\
\hline 5 & 10 & 0 & 0.0098 & 0.0132 & 0.0223 & 0.1332 & 0.0167 \\
\hline 5 & 100 & 0 & 0.0109 & 0.0183 & 0.0198 & 0.1626 & 0.0138 \\
\hline 5 & ]., 000 & 0 & 0.0165 & 0.0231 & 0.0096 & 0.1523 & 0.0132 \\
\hline 5 & 10,000 & 0 & 0.0185 & 0.0596 & 0.0033 & 0.0718 & 0.0183 \\
\hline 5 & 100.000 & 0.0 .32 & & & & & \\
\hline
\end{tabular}


Table 20. Maximum number of critical masses per waste container for granite moderator and reflector

\begin{tabular}{|c|c|c|c|c|c|c|c|}
\hline \multirow{2}{*}{$\begin{array}{l}\text { Nuclear } \\
\text { waste } \\
\text { type }\end{array}$} & \multirow{2}{*}{$\begin{array}{c}\text { Agc } \\
(y \operatorname{tgls})\end{array}$} & \multicolumn{6}{|c|}{$\begin{array}{l}\text { Maximum number of criclcal masses per } \\
\text { rontainer for each actinide oxide }\end{array}$} \\
\hline & & Uranium & Neptuni um & Plutonium & Americium & Curium & $\begin{array}{l}\text { Misture } \\
\text { of Five } \\
\text { Actinidea }\end{array}$ \\
\hline 1 & 1.0 & $n$ & 0.0054 & 0.384 & 0.0087 & 0.0009 & 0 \\
\hline 1 & 100 & 0 & 0.0071 & 0.339 & 0.0185 & 0.0001 & 0 \\
\hline 1 & 1.,000 & 0 & 0.0171 & 0.325 & 0.0047 & 0.00004 & 0 \\
\hline 1 & 10,000 & 0 & 0.0201 & 0.241 & 0.0002 & 0.00002 & 0 \\
\hline 1 & 100,000 & 0 & & & & & \\
\hline 2 & 10 & 0 & 0.02 .44 & 0.0098 & 0.0103 & 0.0039 & 0.0054 \\
\hline 2 & 100 & 0 & 0.0253 & 0.0100 & 0.0094 & 0.0003 & 0.0049 \\
\hline 2. & 1,000 & 0 & 0.0289 & 0.0110 & 0.0040 & 0.0002 & 0.0049 \\
\hline 2 & 10,000 & 0 & 0.0300 & 0.0170 & 0.001 .1 & 0.0001 & 0.0059 \\
\hline 2 & 100,000 & 0 & & & & & \\
\hline 3 & 10 & 0 & 0.0093 & 0.0459 & 0.112 & 0.1716 & 0.1245 \\
\hline 3 & 100 & 0 & 0.0146 & 0.0799 & 0.0996 & 0.0752 & 0.1017 \\
\hline 3 & 1,000 & 0 & $0.0<09$ & 11.0975 & 0.0501 & 0.0679 & 0.0954 \\
\hline 3 & 10,000 & 0.0005 & 0.0509 & 0.170 & 0.0152 & 0.0318 & 0.1240 \\
\hline 3 & 100,000 & 0.0566 & & & . & & \\
\hline 4 & 10 & 0 & 0.0511 & 1.81 & 0.0385 & 0.0033 & 1.41 \\
\hline 4 & 100 & 0 & 0.0587 & 1.59 & 0.0819 & 0.0003 & 1.26 \\
\hline 4 & 1,000 & 0.0024 & 0.1 .0 .3 & 1.51 & 0.0209 & 0.0002 & $1.18 \cdot$ \\
\hline 1 & 10,000 & 0.0541 & $0.11 \mathrm{~h}$ & $1.1 \%$ & 0.001 .0 & 0.0001 & 0.893 \\
\hline 4 & 100,000 & 0.267 & & & & & \\
\hline 5 & 10 & 0 & 0.0195 & 0.0217 & 0.0443 & 0.0599 & 0.0329 \\
\hline 5 & 100 & 0 & 0.0217 & 0.0333 & 0.0395 & 0.0253 & 0.0273 \\
\hline 3 & 1, UUU & $u$ & U. ن329 & 0.0397 & 0.0193 & 0.0227 & 0.0259 \\
\hline 5 & 10.000 & 0 & 0.0369 & 0.0803 & ๑. Пחк5 & $\cap . \cap 1 \cap 7$ & 0.0346 \\
\hline 5 & 100,000 & 0.0166 & & & & & \\
\hline
\end{tabular}


Table 21. Maximum number of critical masses per waste container for salt moderator and reflector

\begin{tabular}{|c|c|c|c|c|c|c|c|}
\hline \multirow{2}{*}{$\begin{array}{l}\text { Nuclear } \\
\text { waste } \\
\text { type }\end{array}$} & \multirow{2}{*}{$\begin{array}{c}\text { Age } \\
\text { (years) }\end{array}$} & \multicolumn{6}{|c|}{$\begin{array}{l}\text { Maximum number of critical masses per } \\
\text { container for each actinide oxide }\end{array}$} \\
\hline & & Uranium & Neptunium & Plutonium & Americium & Curium & $\begin{array}{l}\text { Mixture } \\
\text { of five } \\
\text { actinides }\end{array}$ \\
\hline 1 & 10 & 0 & 0.0033 & 0.222 & 0.0052 & 0.0005 & 0 \\
\hline 1 & 100 & 0 & 0.0043 & 0.195 & 0.0110 & 0.00004 & 0 \\
\hline 1. & 1,000 & 0 & 0.0104 & 0.187 & 0.0028 & 0.00003 & 0 \\
\hline 1 & 10,000 & 0 & 0.0122 & 0.139 & 0.0001 & 0.00001 & 0 \\
\hline 1 & 100,000 & 0 & & & & & \\
\hline 2 & 10 & 0 & 0.0149 & 0.0056 & 0.0060 & 0.0024 & 0.0032 \\
\hline 2 & 100 & 0 & 0.0154 & 0.0058 & 0.0081 & 0.0002 & 0.0030 \\
\hline 2 & 1,000 & 0 & 0.0176 & 0.0063 & 0.0023 & 0.0001 & 0.0029 \\
\hline 2 & 10,000 & 0 & 0.0183 & 0.0099 & 0.0006 & 0.0001 & 0.0036 \\
\hline 2 & 100,000 & 0 & & & & & \\
\hline 3 & 10 & 0 & 0.0057 & 0.0266 & 0.0653 & 0.102 & 0.0715 \\
\hline 3 & 100 & 0 & 0.0089 & 0.0463 & 0.0582 & 0.0477 & 0.0579 \\
\hline 3 & 1,000 & 0 & 0.0249 & 0.0563 & 0.0295 & 0.0437 & 0.0540 \\
\hline 3 & 10,000 & 0 & 0.0310 & 0.0840 & 0.0080 & 0.0205 & 0.0710 \\
\hline 3 & 100,000 & 0.0242 & & & & & \\
\hline 4 & 10 & 0 & 0.0311 & 1.05 & 0.0228 & 0.0020 & 0.807 \\
\hline 4 & 100 & 0 & 0.0357 & 0.917 & 0.0487 & 0.0002 & 0.721 \\
\hline 4 & 1,000 & 0.0014 & 0.0625 & 0.872 & 0.0124 & 0.0001 & 0.670 \\
\hline 4 & 10,000 & 0.0287 & 0.0709 & $0.6 \bigwedge 6$ & 0.0006 & 0.00005 & 0.505 \\
\hline 4 & 100,000 & 0.1536 & & & & & \\
\hline 5 & 10 & 0 & 0.0119 & 0.0126 & 0.0258 & 0.0359 & 0.0195 \\
\hline 5 & 100 & 0 & 0.0132 & 0.0193 & 0.0231 & 0.0160 & 0.0163 \\
\hline 5 & 1,000 & 0 & 0.0200 & 0.0229 & 0.0114 & 0.0146 & 0.0155 \\
\hline 5 & 10,000 & 0 & 0.0225 & 0.0452 & 0.0039 & 0.0069 & 0.0205 \\
\hline 5 & 100,000 & 0.0059 & & & & & \\
\hline
\end{tabular}


For nuclear waste type 3, plutonium-recycled high level waste, minimum critical masses were calculated for water-water, water-granite, granite-granite, brine-brine, brine-salt, and salt-salt moderatorreflector arrangements. The minimum critical masses for these calculations are given in Table 22. The reflector material has the greatest effect on the calculated critical masses for high concentrations of actinide compounds in moderator. For high concentrations of actinide compounds in moderator, granite or salt reflected spheres generally have lower critical masses than water or brine reflected spheres.

\section{ESTIMATED ACCURACY OF THE CALCULATIONAL RESULTS}

The primary limitation on the accuracy of the calculated critical radii and critical masses, neglecting inherent errors that may have existed in the ENDF/B cross section data, was use of six-group cross sections in the computations. Several test cases were run using cross section sets of 42 groups and 218 groups to check the accuracy of the sixgroup calculations.

In all test cases the minimum critical masses for water, brine, granite, and salt mixtures calculated with the fine-group cross-section sets were trom $10 \%$ less to $30 \%$ greater than the values calculated using the six-group computational model. Based on these results, the minimum critical masses given in this paper are estimated to be not less than $30 \%$ smaller and not greater than $10 \%$ higher than critical masses obtained using more detailed calculations.

'the tabulated critical masses given in Appendix 2 are estimated to be from $30 \%$ less to $10 \%$ greater than critical mass values obtained using fine-group calculations for water and brine mixtures at all concentrations of actinide compound in moderator. However, for granite and salt mixtures, as cross section sets were not specifically made for these materials, the calculated critical radii given in the appendix for dilute concentrations of actinide compound in moderator may be a factor of two less than those calculated using fine-group cross sections. For high concentrations of actinide compounds in granite or salt, the calculated critical masses are estimated to be from $30 \%$ less to $10 \%$ greater than those obtained by more detailed calculations. 
Table 22. Calculated critical masses of nuclear waste type 3 for various moderator-reflector compositions

\begin{tabular}{|c|c|c|c|c|c|c|c|}
\hline \multirow{2}{*}{$\begin{array}{l}\text { Actinide } \\
\text { oxide }\end{array}$} & \multirow{2}{*}{$\begin{array}{l}\text { Waste age } \\
\text { (years) }\end{array}$} & \multicolumn{6}{|c|}{ Minimum critical mass $(\mathrm{kg})$} \\
\hline & & Water/water & Water/granite & Granite/granite & Brine/brine & Brine/salt & Salt/salt \\
\hline \multirow[t]{4}{*}{ Urazium } & 10 & $\mathrm{~N}$ & $\mathrm{~N}$ & $\mathrm{~N}$ & $\mathrm{~N}$. & $\mathrm{N}$ & $\mathrm{N}$ \\
\hline & 100 & $\mathrm{~N}$ & $\mathrm{~N}$ & $\mathrm{~N}$ & $\mathrm{~N}$ & $\mathrm{~N}$ & $\mathrm{~N}$ \\
\hline & 1,300 & $\mathrm{~N}$ & $\mathrm{~N}$ & $\mathrm{~N}$ & $\mathrm{~N}$ & $\mathrm{~N}$ & $\mathrm{~N}$ \\
\hline & 10,000 & 307.2 & 282.5 & 23609.0 & $\mathrm{~N}$ & $\mathrm{~N}$ & $\mathrm{~N}$ \\
\hline \multirow[t]{4}{*}{ Plutonium } & 10 & 28.4 & 18.6 & 18.6 & 31.6 & 32.1 & 32.1 \\
\hline & 100 & 41.5 & 23.4 & 23.4 & 43.6 & 40.4 & 40.4 \\
\hline & 1.,000 & 32.0 & 20.3 & 20.3 & 35.6 & 35.2 & 35.2 \\
\hline & 10,000 & 1.77 & 1.49 & 14.5 & 17.4 & 15.6 & 29.4 \\
\hline \multirow[t]{4}{*}{ Americium } & 10 & 84.4 & 46.6 & 46.6 & 92.0 & 80.0 & 80.0 \\
\hline & 100 & 91.7 & 49.7 & 49.7 & 98.9 & 85.1 & 85.1 \\
\hline & 1,000 & 132.5 & 68.8 & 68.8 & 139.4 & 116.8 & 116.8 \\
\hline & 10,000 & 245.5 & 90.2 & 90.2 & 256.1 & 172.3 & 172.3 \\
\hline \multirow[t]{4}{*}{ Curiùm } & 10 & 0.325 & 0.456 & 7.81 & 3.35 & 3.61 & 13.1 \\
\hline & 100 & 0.0588 & 0.0843 & 3.55 & 0.551 & 0.604 & 5.60 \\
\hline & 1,000 & 0.0512 & 0.0724 & 3.15 & 0.461 & 0.510 & 4.90 \\
\hline & 10,000 & 0.0493 & 0.0697 & 3.61 & 0.451 & 0.488 & 6.23 \\
\hline Mixture of & 10 & 267.6 & 151.9 & 151.9 & 304.8 & 264.3 & 264.3 \\
\hline \multirow[t]{3}{*}{ five actinides } & 100 & 340.8 & 185.6 & 185.6 & 381.9 & 326.1 & 326.1 \\
\hline & 1,000 & 361.2 & 197.4 & 197.4 & 407.7 & 348.8 & 348.8 \\
\hline & 10,000 & 237.4 & 151.4 & 151.4 & 286.7 & 264.4 & 264.4 \\
\hline
\end{tabular}




\section{DISCUSSION OF THE CALCULATIONAL RESULTS AND CONCIUSIONS}

Several general observations on the calculational results are presented in this section.

1. Neptunium oxide and americium oxide have such large minimum critical masses $(\sim 60-90 \mathrm{~kg}$ ) that they probably do not present a potential criticality problem.

2. The only actinide, disregarding neptunfum, in luclear waste that can form morc critigal massps at $10 n, 0 n n$ years than at 10,000 years is uranium.

3. The only waste type which does not have at least one critical mass per waste container at any waste age in any geologic material is waste type 2, high level waste from fresh uranium fuel.

The following conclusions are related to whether ground water has intruded into the waste repository or whether water already-present in the repository has collected in some manner.

1. If water is not present in the repository, the only waste type which has at least one crltled mass per waste containcr for any geologic material is high level waste plus $100 \%$ of the plutonium in discharged fue1, type 4 waste.

2. Even if water is present in a salt repository (in the form of brine), again there is only one waste type which has at least one critiral mass per container, high level waste plus $100 \%$ of the plutonium.

3. If water is present in a granite or shale repository, several waste types have enough heavy-metal oxides to form at least one critical mass per waste container.

\section{ACKNOWLEDGMENTS}

The author wishee to express his gratitude to the following people for their assistance with this work: G. H. Jenks of OWI for conceiving the study and supervising the work, E. D. Blakeman and W. E. Thomas for many helpful conversations on neutron cross section processing and computational model development, R. A. Kisner for supplying the nuclear waste 
decay calculational results, W. E. Ford, III, C. C. Webster, and R. M. Westfall for help with the cross section processing; D. R. Vondy for help with the multiplication factor extrapolation procedure; S. R. McNeany and J. D. Jenkins for reviewing the draft report; and Donna Conger and the Reports office for preparing the final report.

\section{REFERENCES}

1. G. H. Jenks, Oak Ridge National Laboratory, personal communication to E. J. Allen, Oak Ridge National Laboratory, April 6, 1978.

2. Waste Isolation Facility Description Bedded Salt, prepared by Parsons Brinckerhoff Quade and Douglas, Inc., New York, Y/OWI/SUB-76/16506 (September 1976).

3. M. J. Bell, ORIGEN - The ORNL Isotope Generation and Depletion Code, ORNL-4628 (May 1973).

4. G. H. Jenks, Oak Ridge National Laboratory, personal communication to E. J. Allen, Oak Ridge National Laboratory, Nov. 23, 1977.

5. R. Douglas O'Dell (Ed.), Nuclear Criticality Safety, TID-26286 (1974).

6. N. M. Greene et al., AMPX: A Modular Code System for Generating Coupled Multigroup Neutron-Gamma Libraries from ENDF/B, ORNL/TM-3706 (March 1976).

7. W. E. Ford, III, C. C. Webster, and R. M. Westfall, A218-Group Neutron Cross-Section Library in the AMPX Master Interface Format for Criticality Safety Studies, ORNL/CSD/TM-4 (July 1976).

8. ENDF is the Evaluated Nuclear Data File and is the national reference set of evaluated cross section data.

9. E. D. Clayton and S. R. Bierman, "Criticality Problems of Actinide Elements," Actinides Reviews 1, 409-432 (1971). 


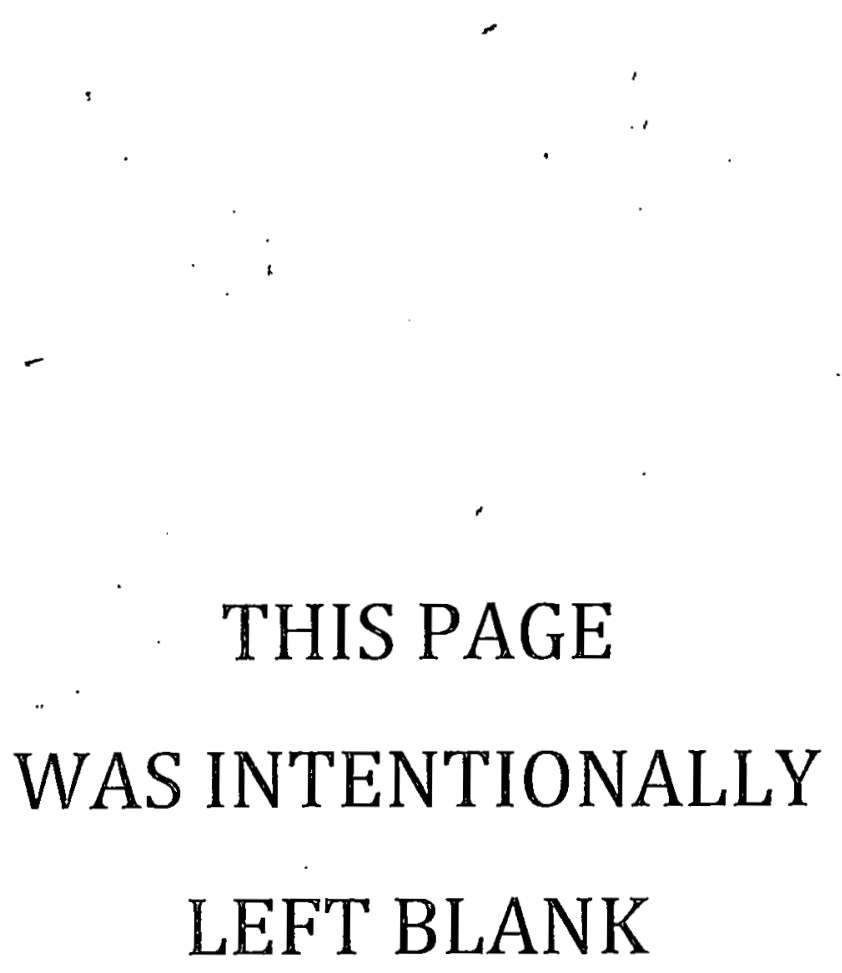


Appendix 1

CRITICAL MASS COMPUTATIONAL MODEL

The function of the computational model was to calculate and prepare tables and plots of critical mass and critical radius versus actinide compound concentration in moderator material. Several unique approaches and methods were used in the computational model to reduce computer time and data manipulation.

The computational model performs progressive radial search calculations until a curve of critical mass versus actinide compound concentration in mixture is generated. The calculations start at the maximum theoretical density of actinide compound. A search for the critical radius is made. Then the concentration of actinide compound is reduced by a factor of $(0.1)^{1 / 3}$ and the remaining volume is replaced by the moderator material. The critical radius for the new composition is calculated. These steps continue until criticality is not achieved or the critical radius exceeds one meter. Then, the smallest critical mass is determined and about this point two more concentrations are selected and critical radii are calculated. The results are then output in the form of tables and plots. In all critical mass calculations the mixture of actinide compound and moderator material are surrounded by a reflector of 0.20 meters thickness.

The computational model had to be accurate from very high actinide compound concentrations to very low concentrations $\left(20.01 \mathrm{~g} / \mathrm{cm}^{3}\right)$. To satisfy this requirement, a discrete-ordinates neutron-transport method was selected to compute the multiplication factors for each spherical radius. The discrete-ordinates method selected uses a diamond-difference* scheme and treats four angles (S4) and second-order scattering (P2). Critical radii searches for each concentration are made in the following manner. A starting radius to begin calculations is estimated. This starting radius is selected to be the critical radius of the previous concentration of actinide compound in moderator or $7.5 \mathrm{~cm}$ for the first

*George I. Bell and Samuel Glasstone, Nuctear Reactor Theory, VanNostrand Reinhold, New York, 1970. 
concentration (maximum theoretical density). Multiplication factors are calculated for radii of 0.67 and 1.5 times the starting radius. These multiplication factors and radii are then used in the equation

$$
1 / k=a+b / R^{2}
$$

to estimate $a$ and $b$. In this equation, $k$ is the multiplication factor and $R$ is the spherical radius. This equation fairly accurately describes the curve of multiplication factor versus spherical radius. The third radius is calculated using this equation by setting $k=1.0$. A multiplication factor for this third radius is next calculated and the parameters $a$ and $b$ are again calculated using the additional information from the third radius. A fourth radius and multiplication factor are then calculated. At this point the search is normally completed. However, if for some reason the multiplication factor differs from unity by more than $2 \%$, the search calculations continue. Usually, the multiplication factor for the fourth radius is within $0.5 \%$ of unity. If during the search the radius exceeds one meter, the multiplication factor for a sphere of one meter radius is calculated. If this multiplication factor is less than unity, the search calculations are terminated.

lihe multiplication factors for each radius are calculated using the following procedure. The angular neutron flux calculations are allowed to proceed without interruption for 25 outer iterations. For each outer iteration, two inner iterations are made for groups $1-4$ and four inner 1terations are made for the two lower energy groups. After the 23 outer iterations are performed, if the current multiplication factor differs by less than $0.01 \%$ from the proceeding multiplication factor, convergence is assumed and the current multiplication factor is taken as the true multiplication factor. If convergence is not satisfied, single-mode extrapolation on the multiplication factor is performed if the requirements for extrapolation are satisfied. If extrapolation criteria are not satisfied, outer iterations continue until convergence, extrapolation, or the maximum number (65) of outer iterations is reached. In all test cases the maximum number of outer iterations was never reached. Extrapolation or convergence generally occurred between 25 and 35 outer iterations. 
Single-mode extrapolation on the multiplication factor is carried out using the following procedure. Consider the equation:

$$
k_{n}-k_{n-1}=c\left(k_{t}-k_{n}\right)
$$

where

$$
\begin{aligned}
& k_{n}=\text { multiplication factor for nth outer iterations, } \\
& k_{t}=\text { the multiplication factor at the infinite outer iteration, }
\end{aligned}
$$
and

$$
c=a \text { constant }
$$

This equation assumes that the difference between successive multiplication factors decreases as the calculated multiplication factor approaches the true multiplication factor. From this equation the true multiplication factor can be estimated:

$$
k_{e}=k_{t}=k_{n}+\mu\left(k_{n}-k_{n-1}\right) /(1-\mu)
$$

where

$$
k_{e}=\text { extrapolated multiplication factor, }
$$

and

$$
\mu=\left(k_{n}-k_{n-1}\right) /\left(k_{n-1}-k_{n-2}\right)=1 /(1+c)
$$

The value of $\mu$ must be constant, less than unity, and greater than zern. Extrapolation is allowed (after a minimum of 25 outer iterations) if $\mu$ is less than 0.99 but greater than zero and successive $\mu$ 's differ by less than $2 \%$.

The cross section handling by the computational model is straightforward. rinss section resonances were tiedled for various metal-tohydrogen ratios for each actinide and tables of absorption and fission cross sections were prepared. For each concentration of actinide compound in moderator, the tabulated cross sections are interpolated depending on the ratio of actinide to hydrogen concentration. Therefore, a unique cross section set is used for each concentration of actinide compound in the moderator. 
Input other than cross section information which is the same for every case consists of the following seven cards:

CARD 1 Title card of all calculations Format(20A4)

CARD 2 NCALC, NPLOT, NRADP Format(24I3)

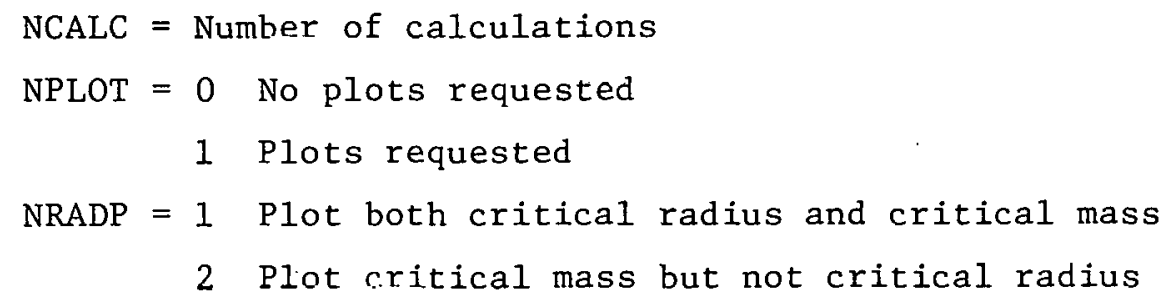

The following cards are input NCALC times in the order shown lut each of the NCALC calculations.

CARD 3 Title card of current calculation Format(8A4)

CARD 4 Number of nuclides in the reflector, density of the reflector in grams per cubic centimeter, number of nuclides in the moderator, density of the moderator, number of nuclides in the actinide compounds, maximum density of the actinide compounds Format(6(I3,E9.3))

CARD 5 Cross section identifier for first nuclide in the reflector, mass fraction of first nuclide in the reflector, cross section identifier for sernnd nuclide in the reflector, . . continue until all nuclides in the reflectur are described Format $(6($ I3, E9.3))

CARD 6 Same as Card 5 but for the moderator

$C \Lambda R D 7$ Same as Card $b$ but for the aclinide compound 3

Output for each calculation consists of several tables and plots if requested. The first table summarizes input information, such as moderator, and actinide compound compositiong. Tho next tahle gives concentrations of actinide compound in the moderator, critical radli at these concentrations, critical masses, and calculated multiplication factors. The table continues until the actinide compound concentration is so low that criticalfty cannot be achieved for a radius of one meter. If plots are requested, critical radius and critical mass are plotted against actinide compound concentration in the moderator. 
Running time and storage requirements on the IBM 360-91 computer are low. To do a calculation of 15 critical radii searches and plotting these points requires approximately two minutes computer time and less than 270,000 bytes of computer memory. 
THIS PAGE

WAS INTENTIONALLY

LEFT BLANK 
Appendix 2

PLOTS AND TABLES OF CALCULATED CRITICAL MASSES

Many plots and tables of critical mass versus concentration of actinide oxide in moderator were generated. In this appendix, the calculated critical masses are tabulated for nearly all the water, brine, granite, and salt mixtures studied. Critical mass plots are given for nearly all the water and brine mixtures studied. Each plot or table has a unique identification which is explained below.

Identification for each case is:

CASE HLW,PWR-WW, XXXXXX,Y,Y,Z-O

where

$$
\begin{aligned}
\mathrm{WW} & =\mathrm{SF}=\text { Type } 1 \text { waste (spent fuel) } \\
& =\mathrm{UR}=\text { Type } 2 \text { waste (fresh uranium) } \\
& =\mathrm{PU}=\text { Type } 3 \text { waste (recycled plutonium) } \\
& =\mathrm{PP}=\text { Type } 4 \text { waste (plus plutonium) } \\
& =\mathrm{UP}=\text { Type } 5 \text { waste (Mixture of Type } 2 \text { and Type } 3 \text { waste) } \\
\mathrm{XXXXXX} & =\text { waste age } \text { in years } \\
\mathrm{Y}, \mathrm{Y} & =\mathrm{W}, \mathrm{W}=\text { water moderated and reflected } \\
& =\mathrm{B}, \mathrm{B}=\text { brine moderated and reflected } \\
& =\mathrm{G}, \mathrm{G}=\text { granite moderated and reflected } \\
& =\mathrm{S}, \mathrm{S}=\text { salt moderated and reflected } \\
\mathrm{Z}-\mathrm{O} & =\mathrm{U}, \mathrm{N}, \mathrm{P}, \Lambda, \mathrm{C}=\text { oxide of uranium, neptunium, plutonium, } \\
& =\mathrm{UNPAC}-\mathrm{O}=\text { mixture of all five actinide oxides }
\end{aligned}
$$



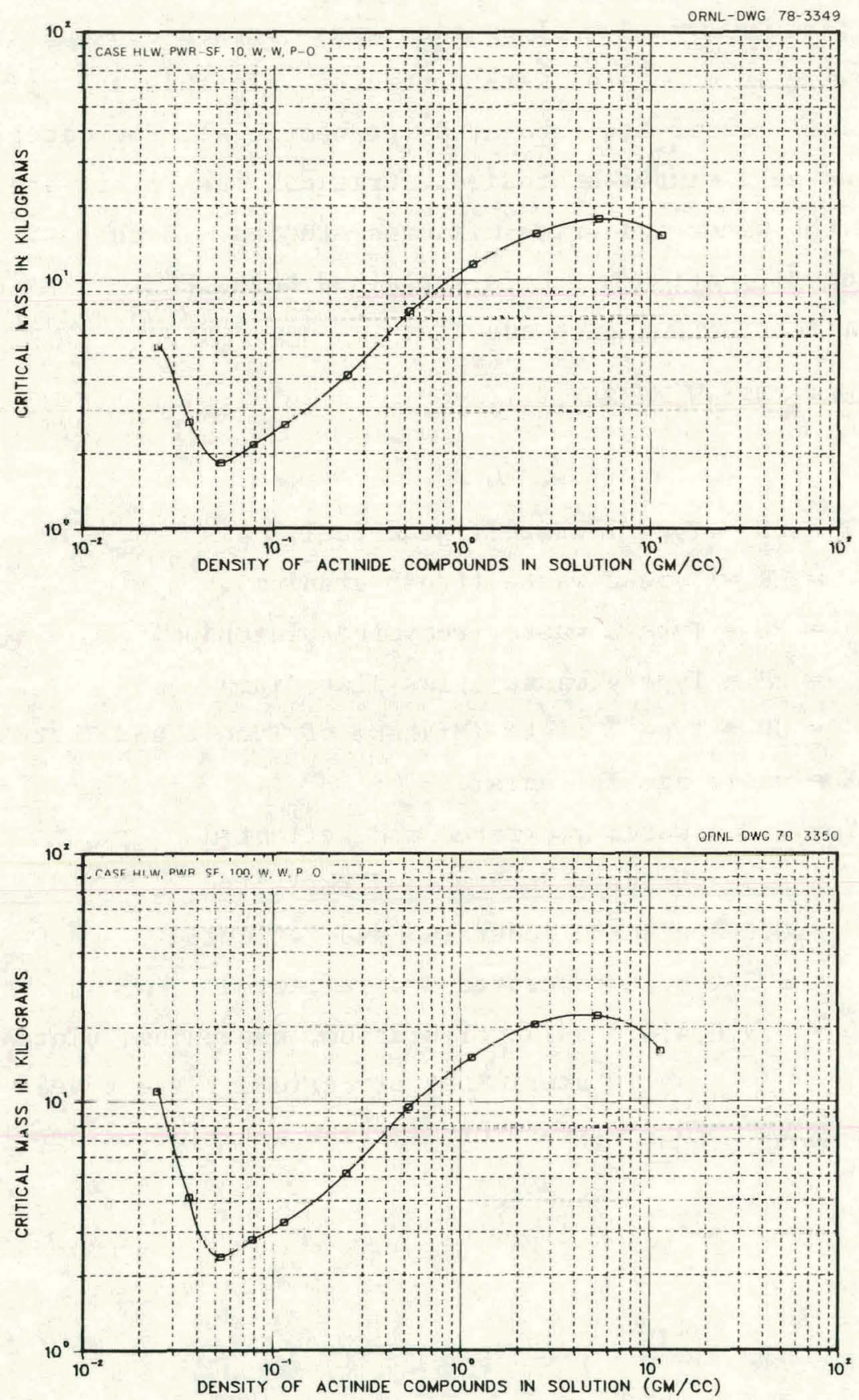

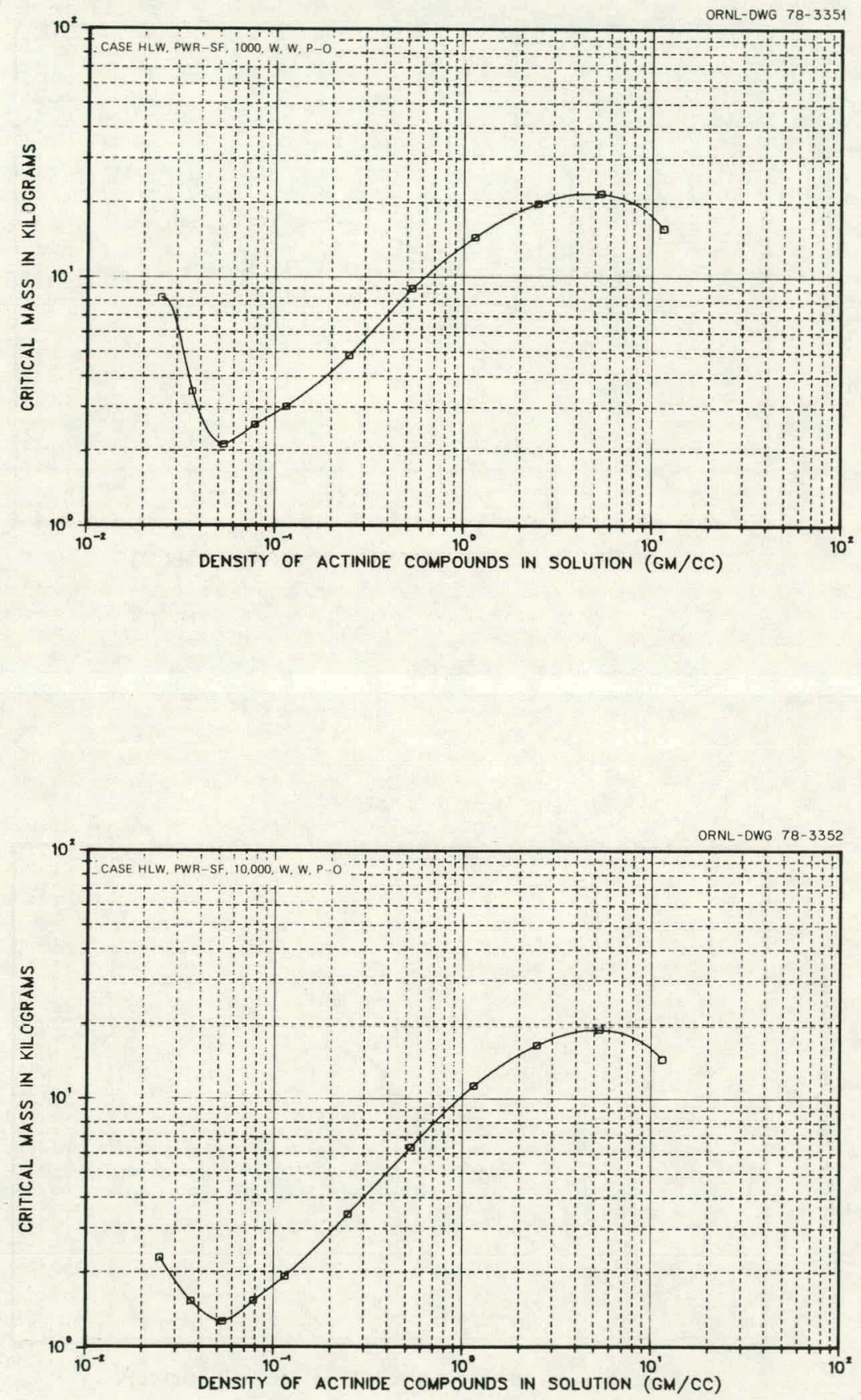

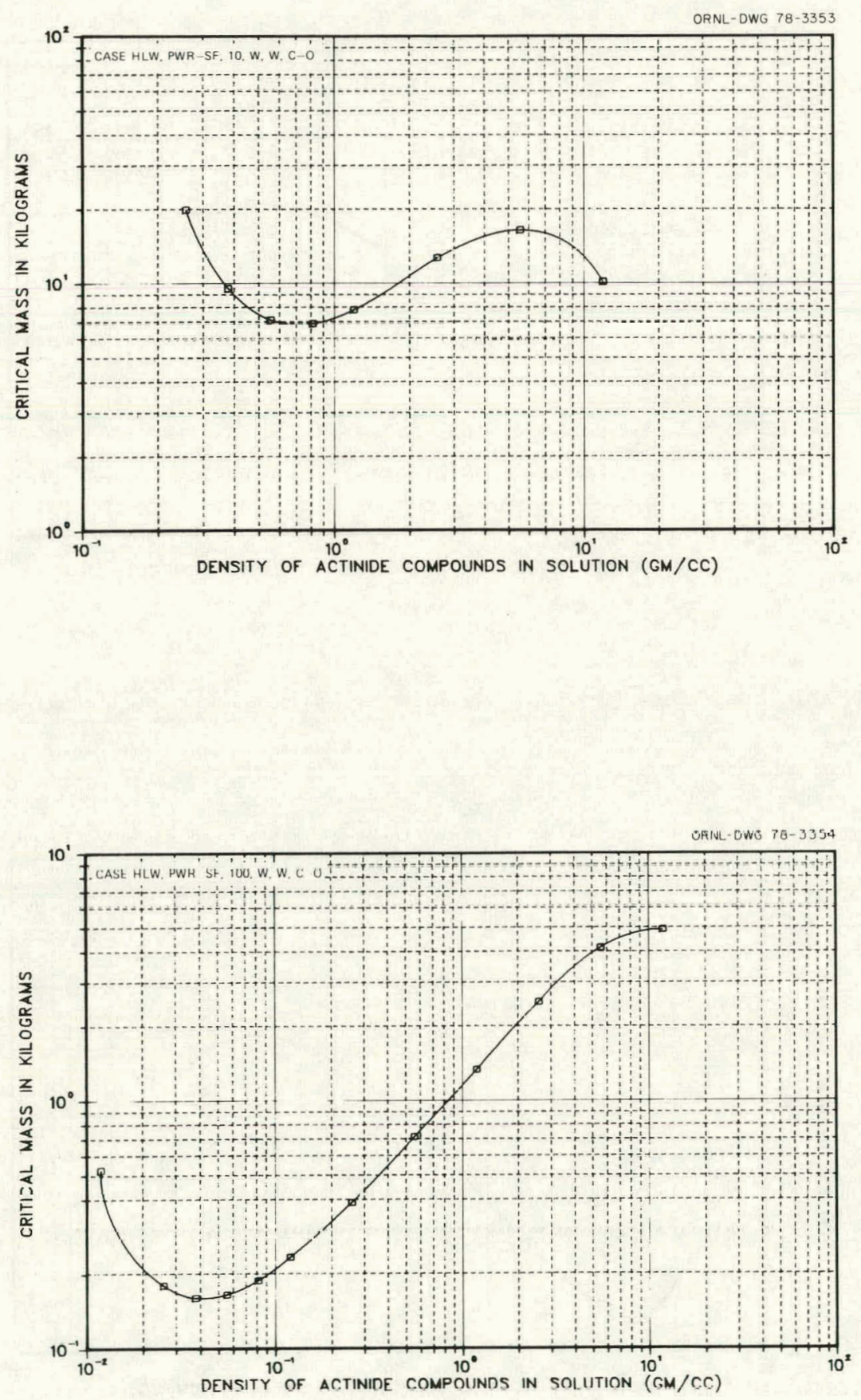

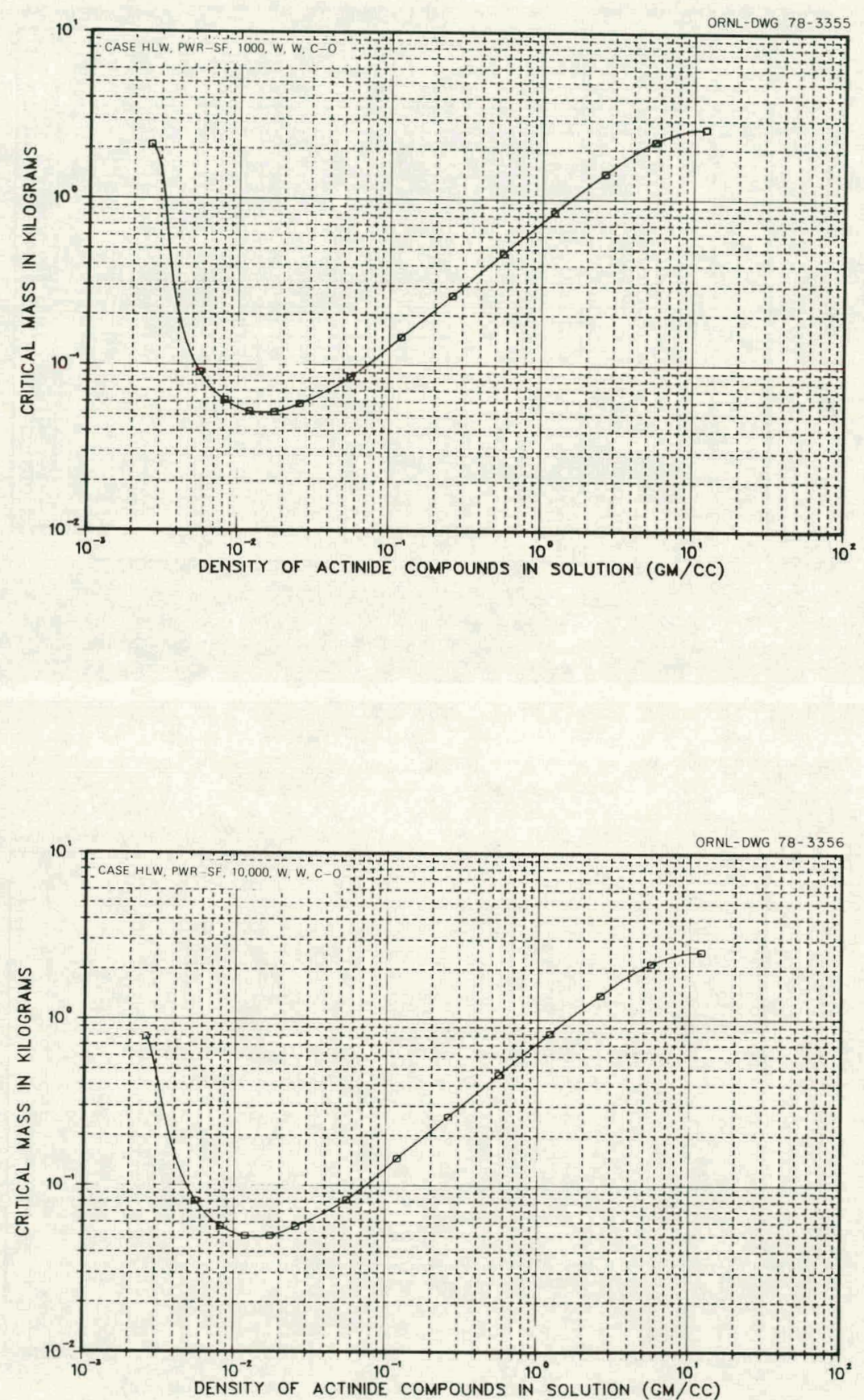

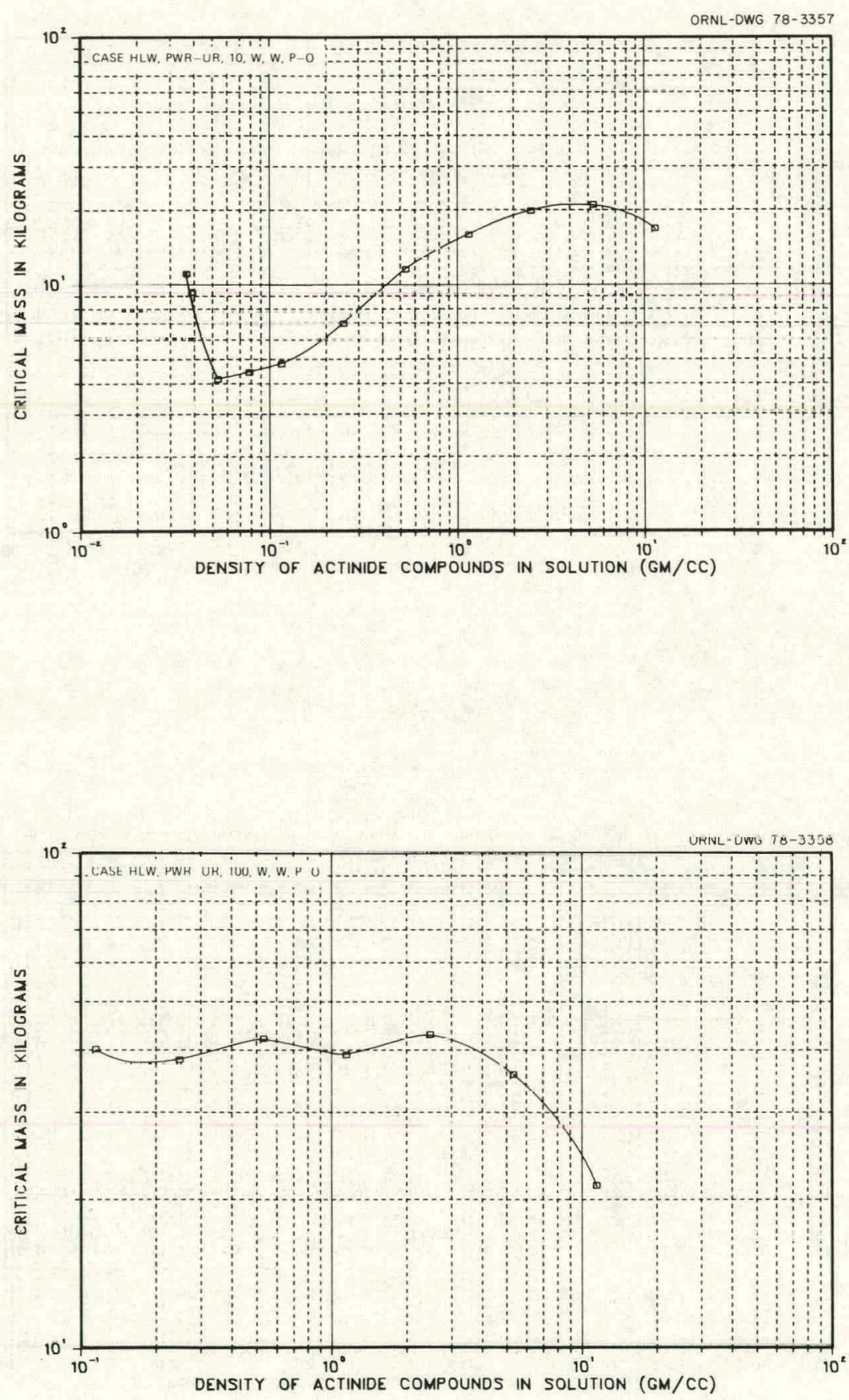

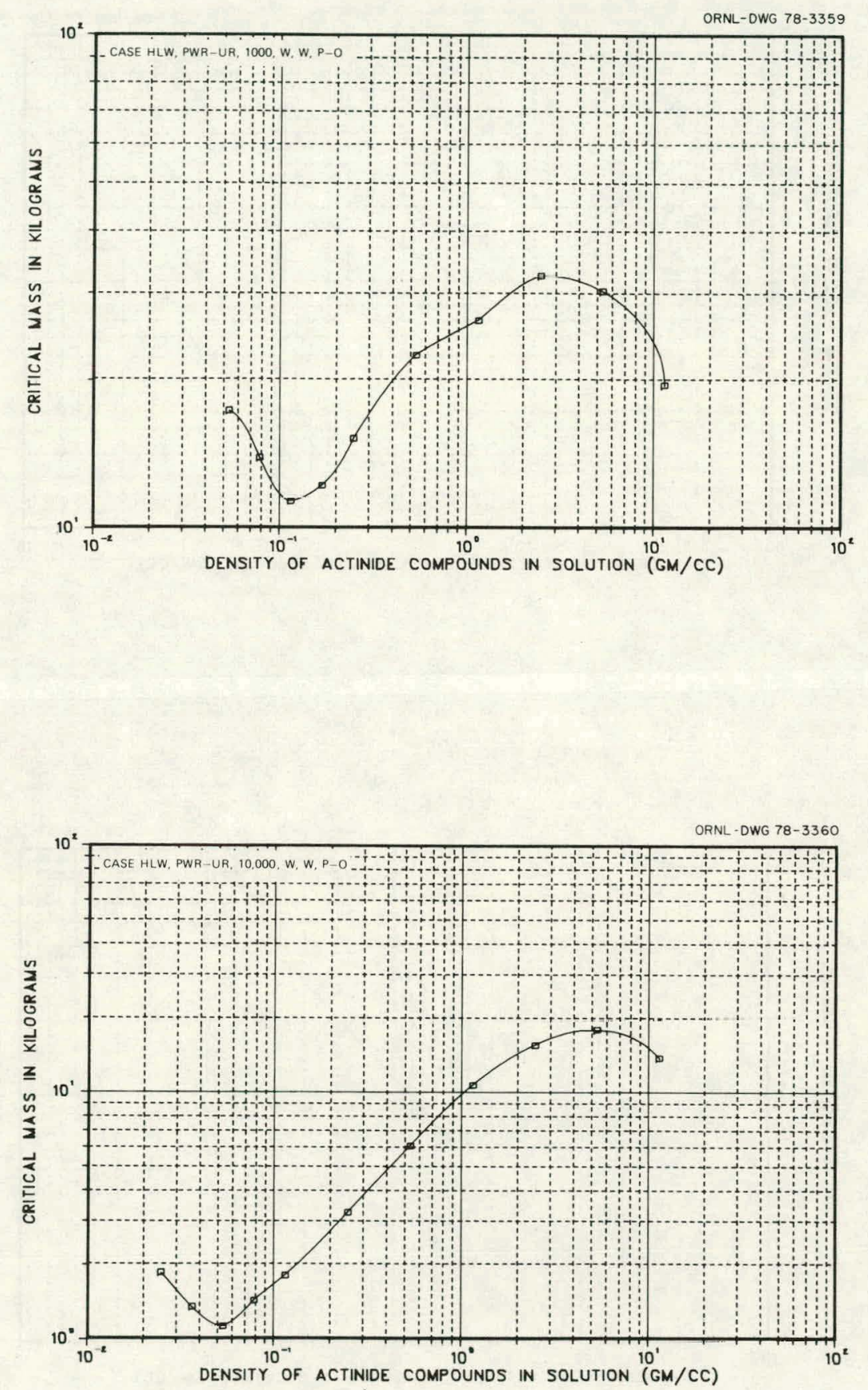

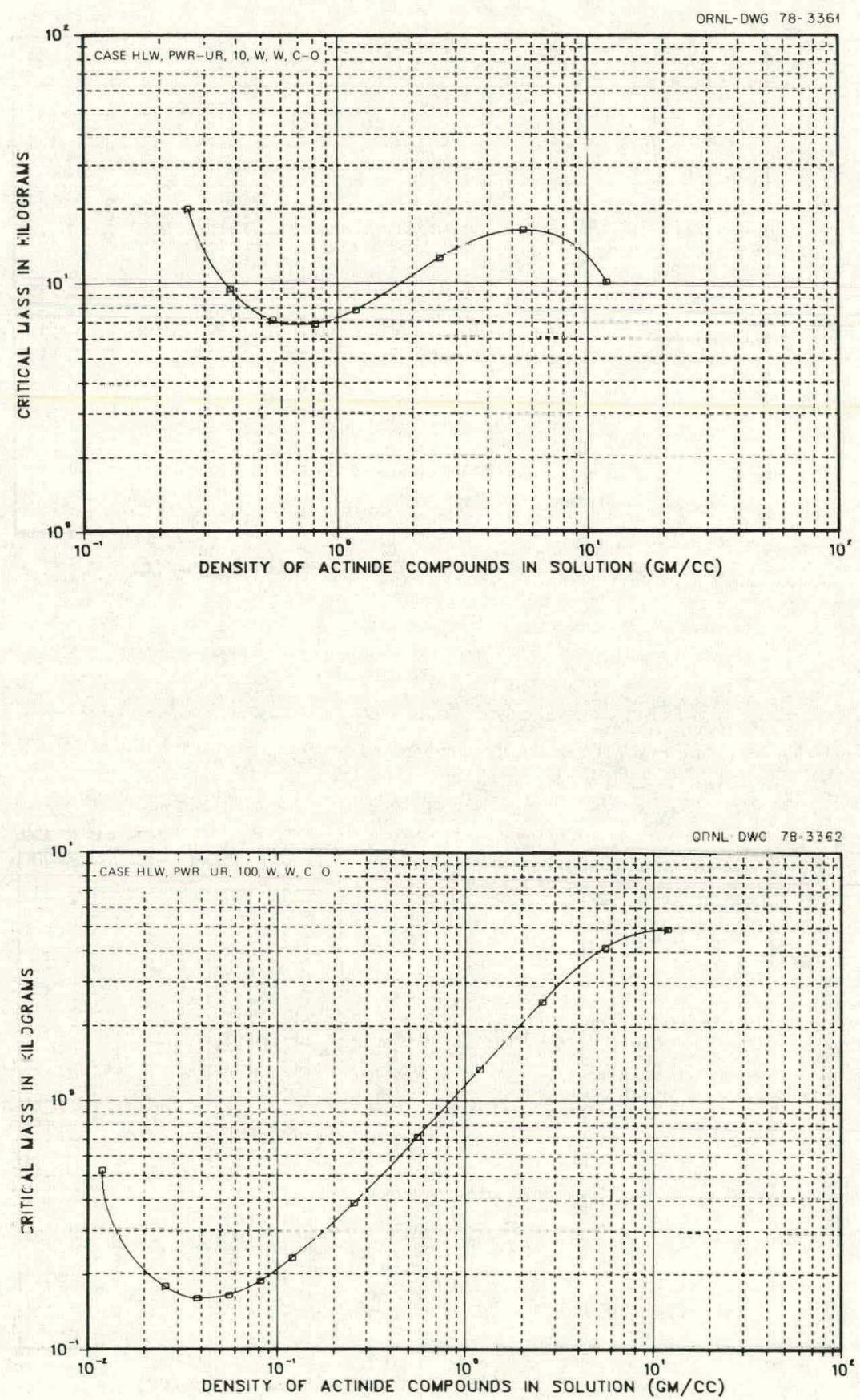

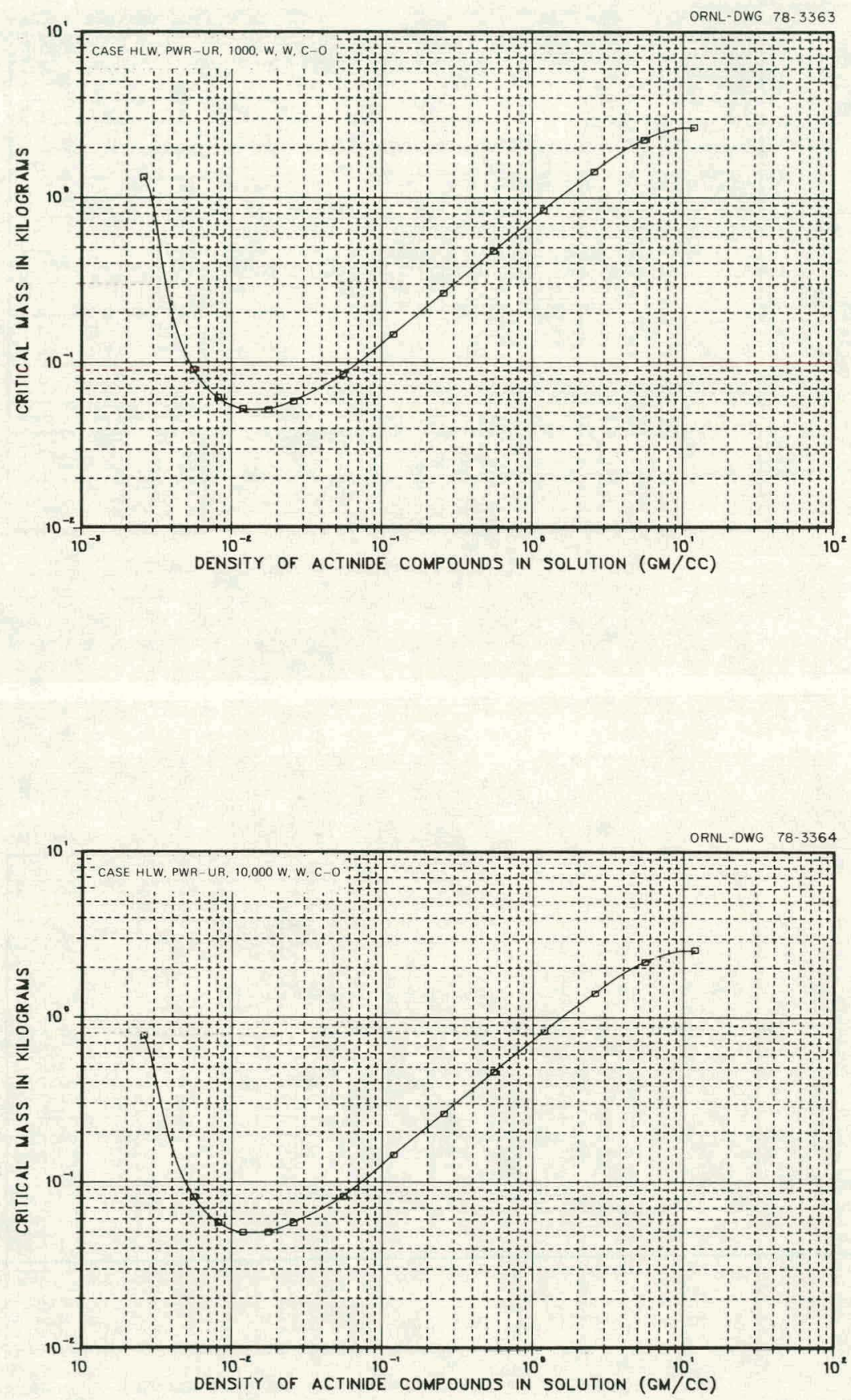

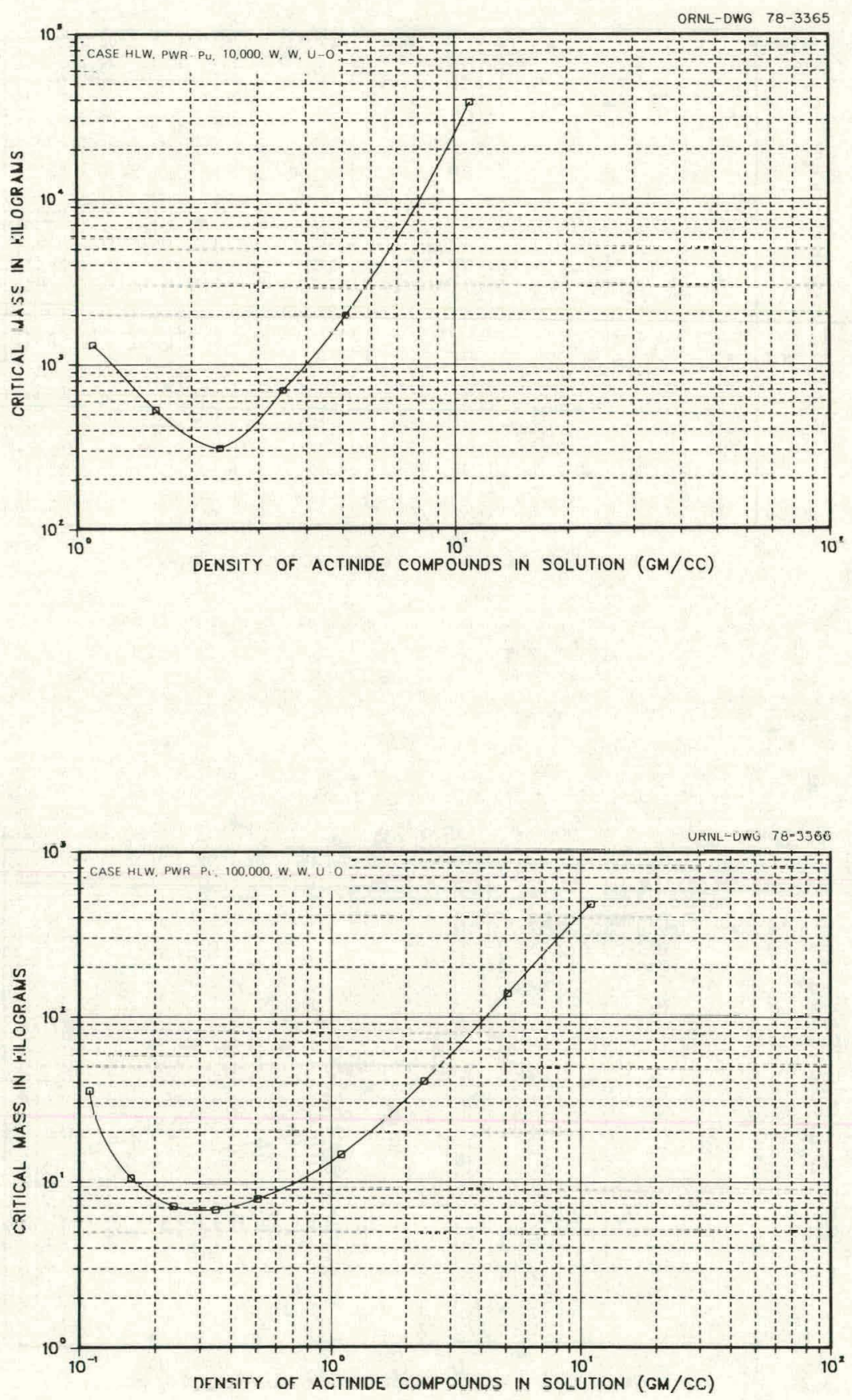

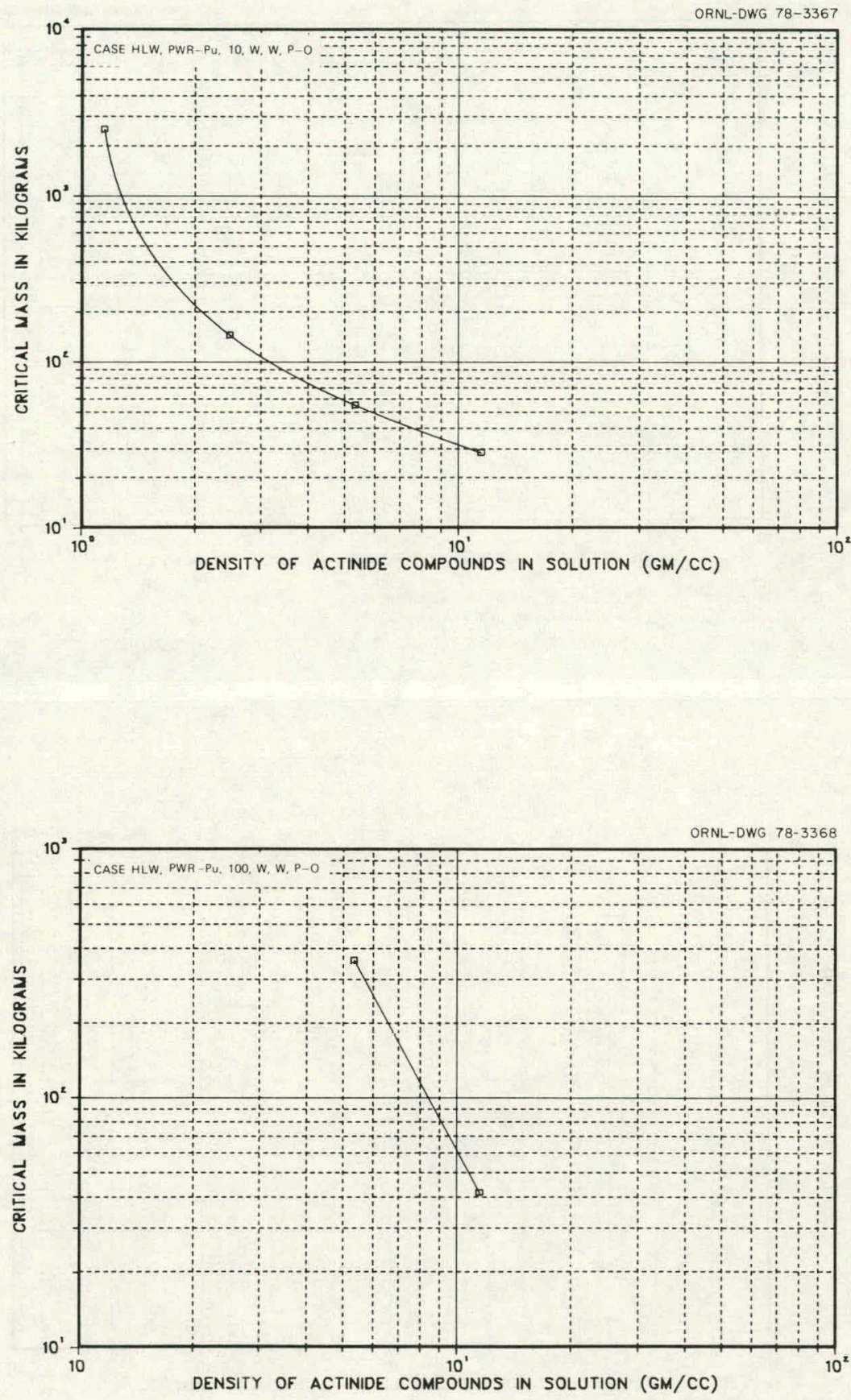

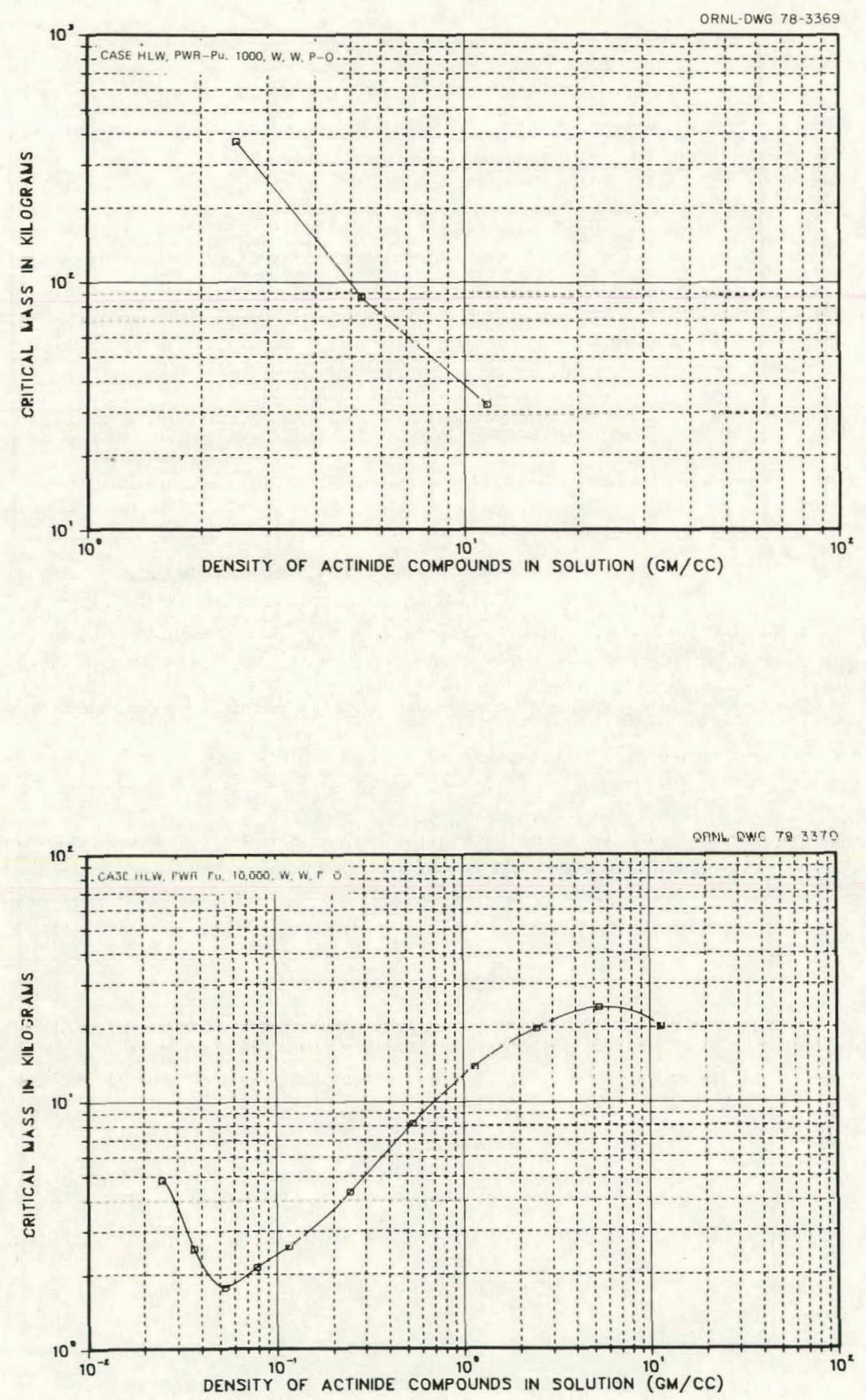

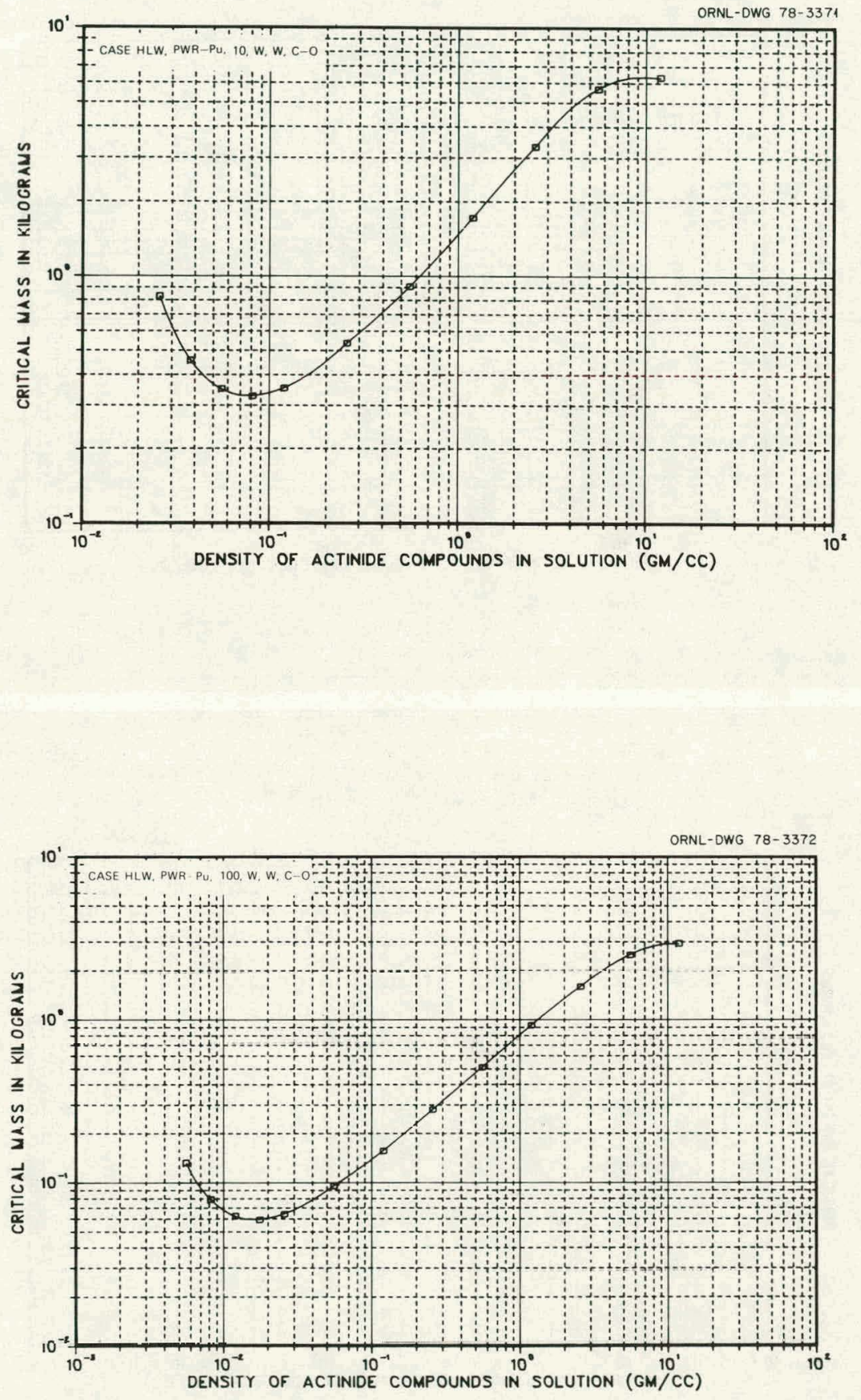

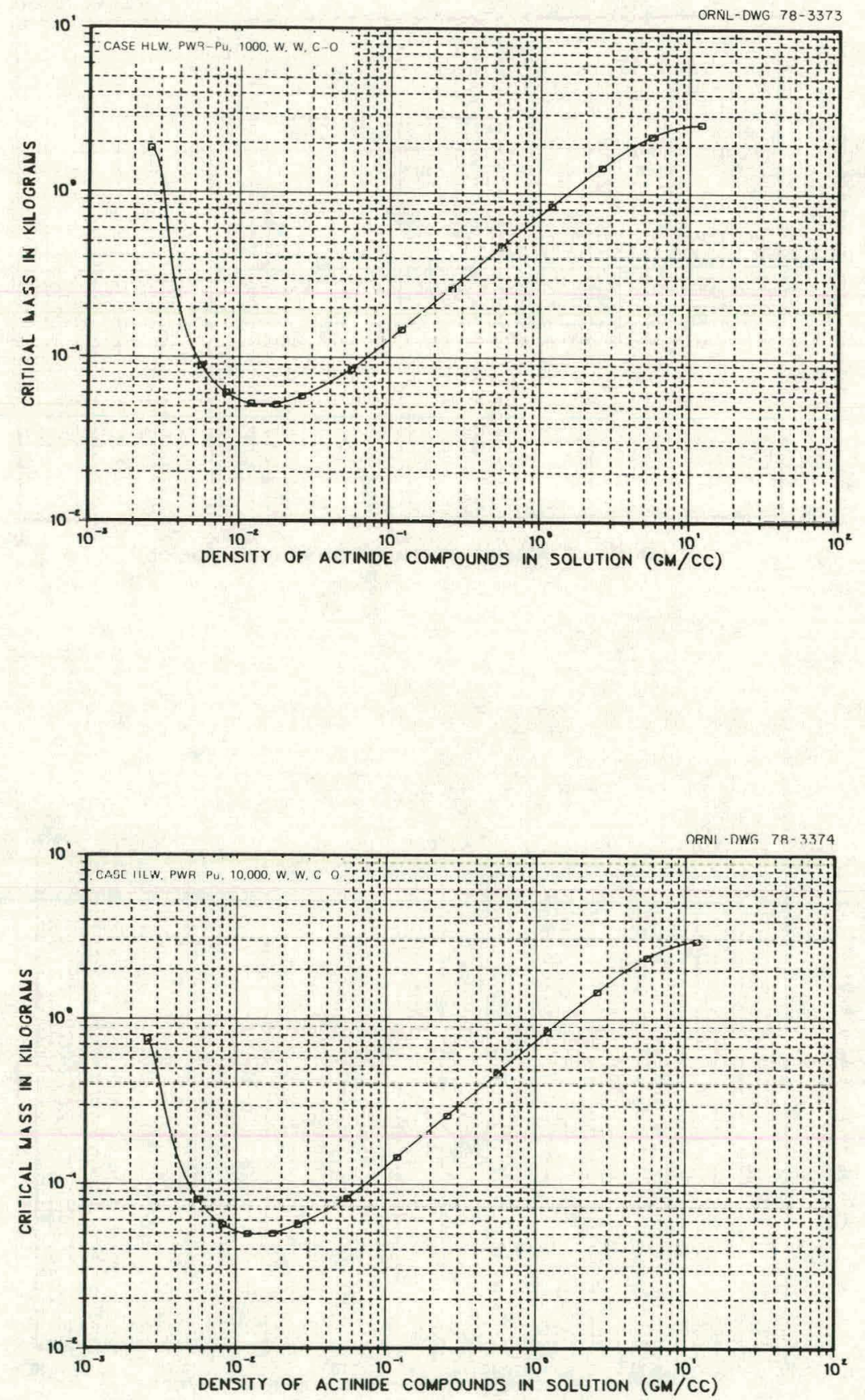

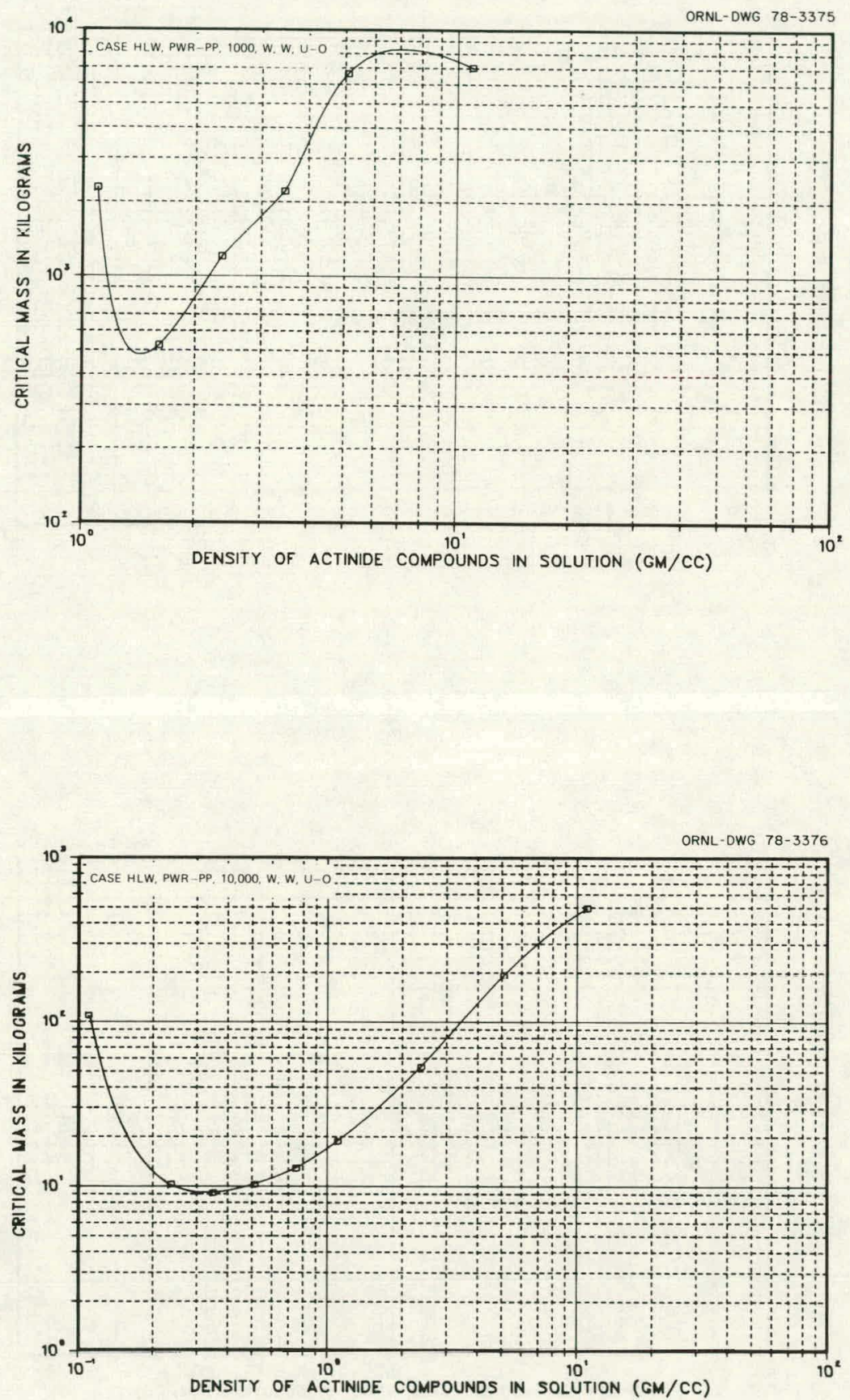

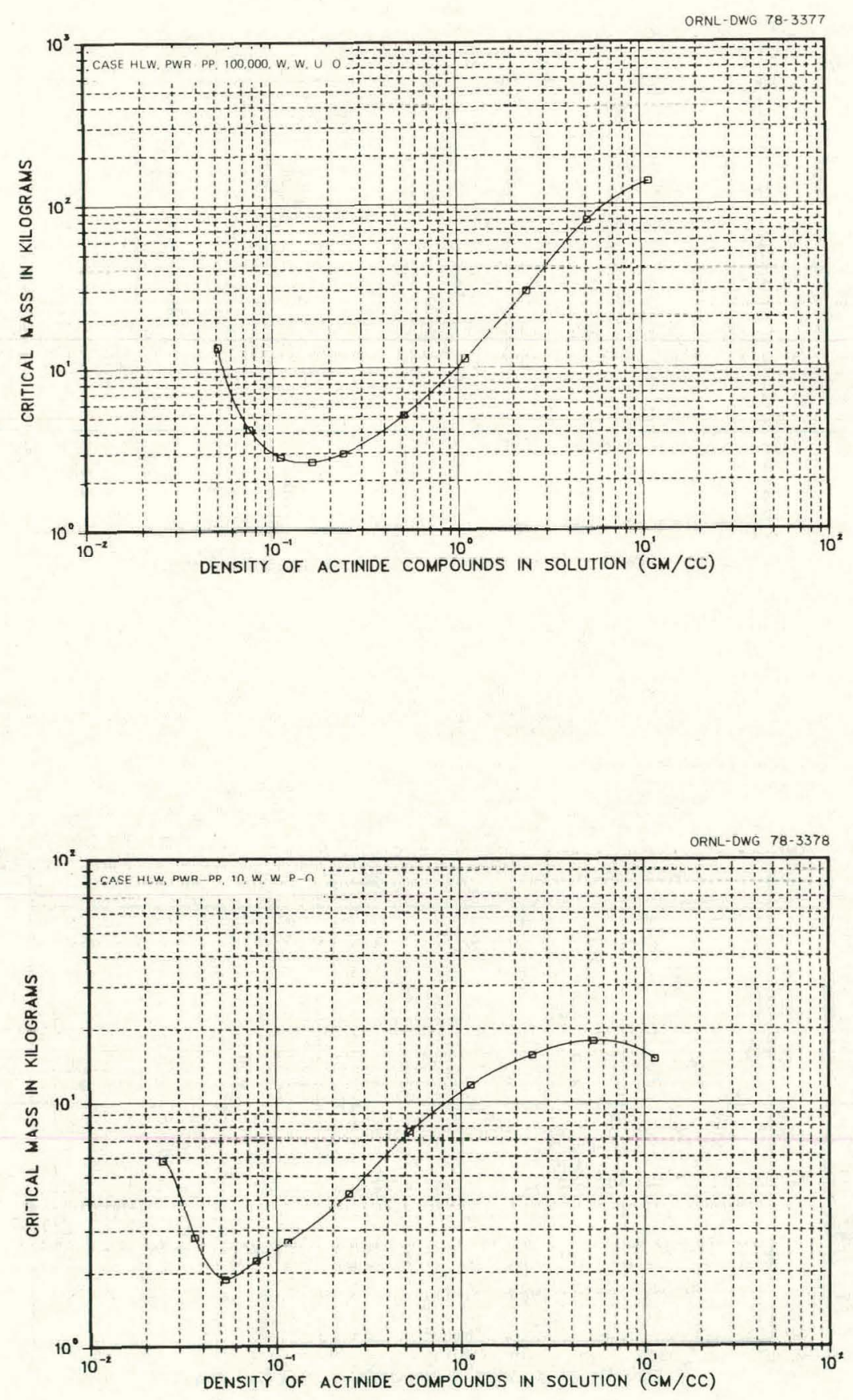

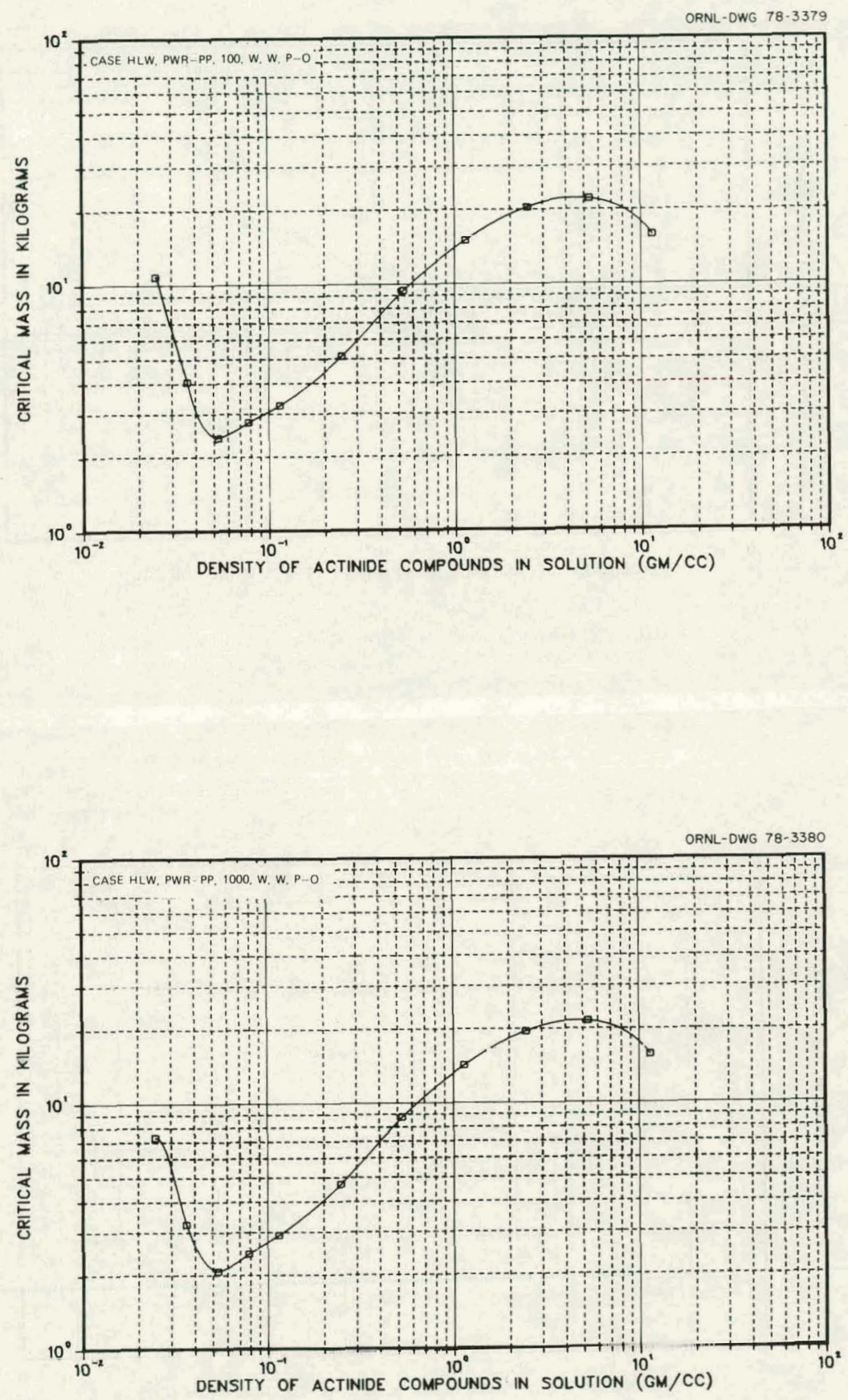

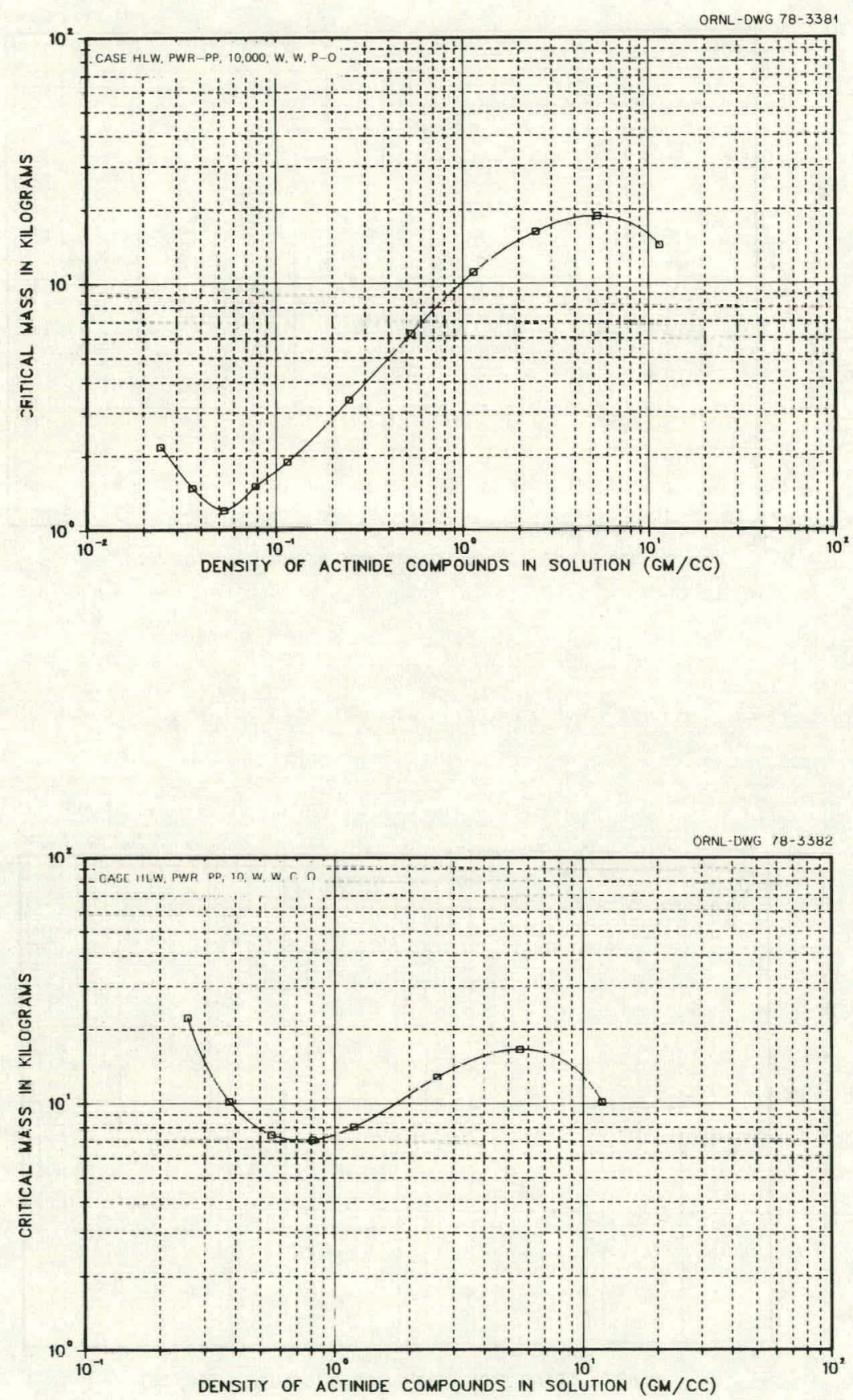

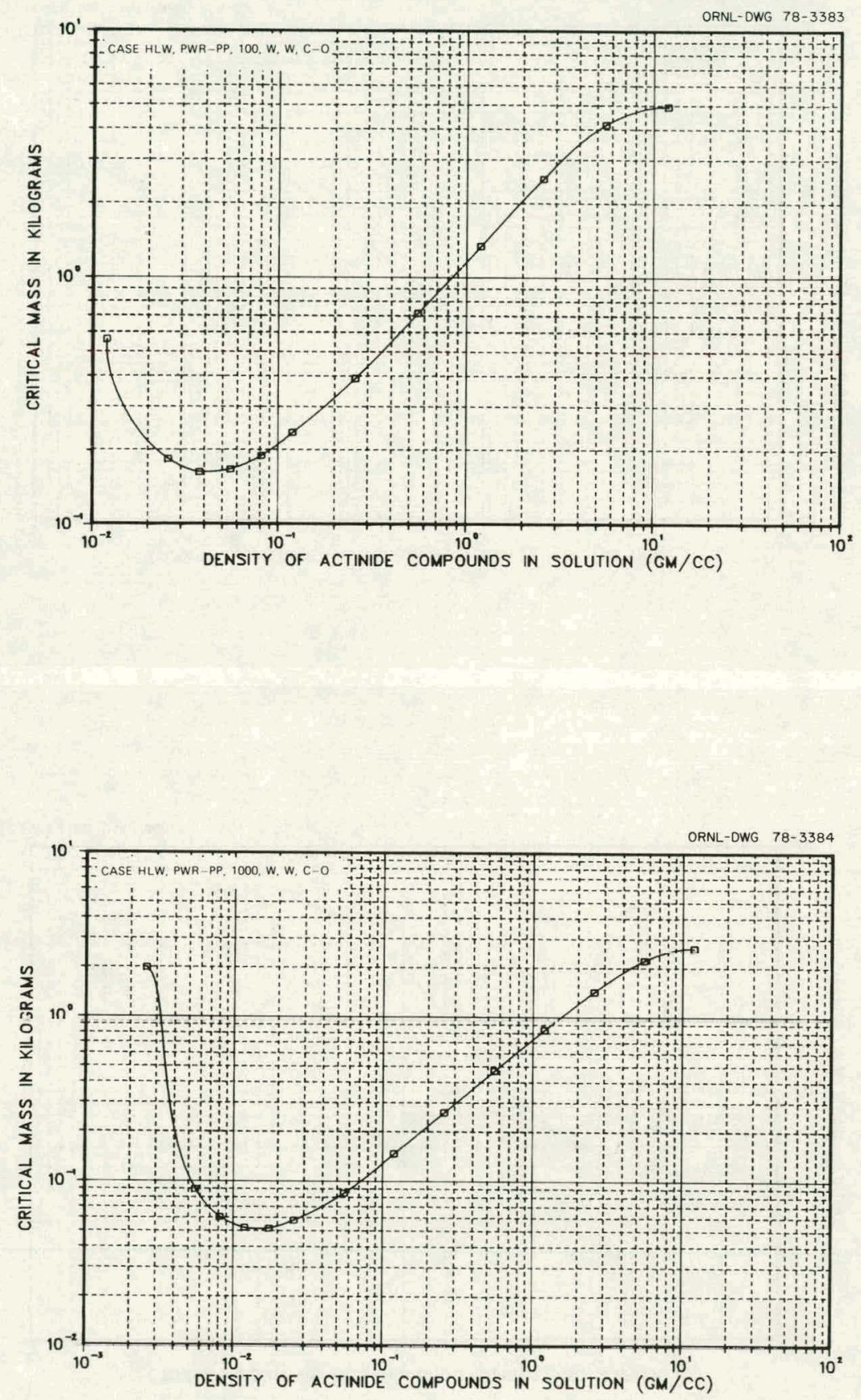

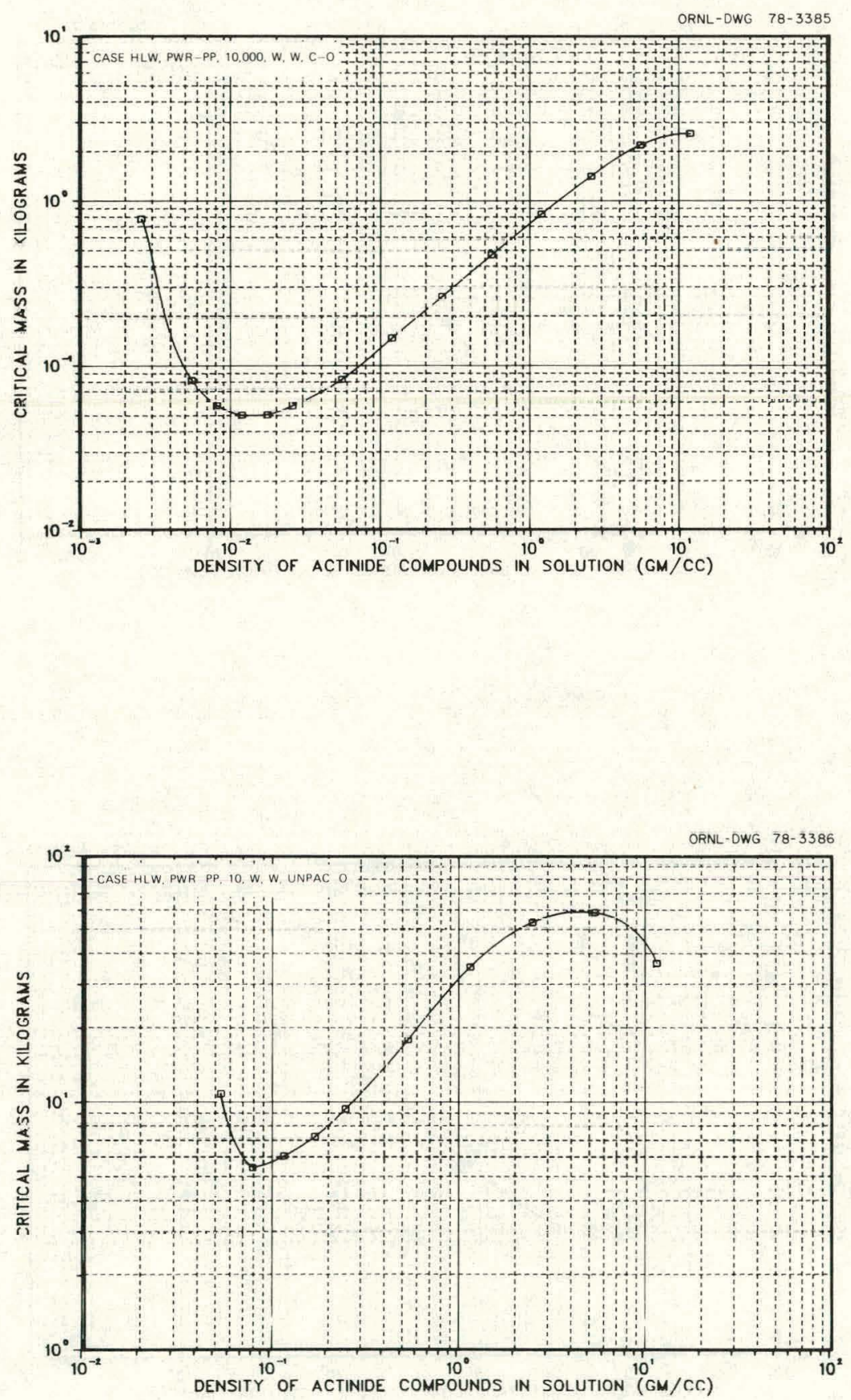

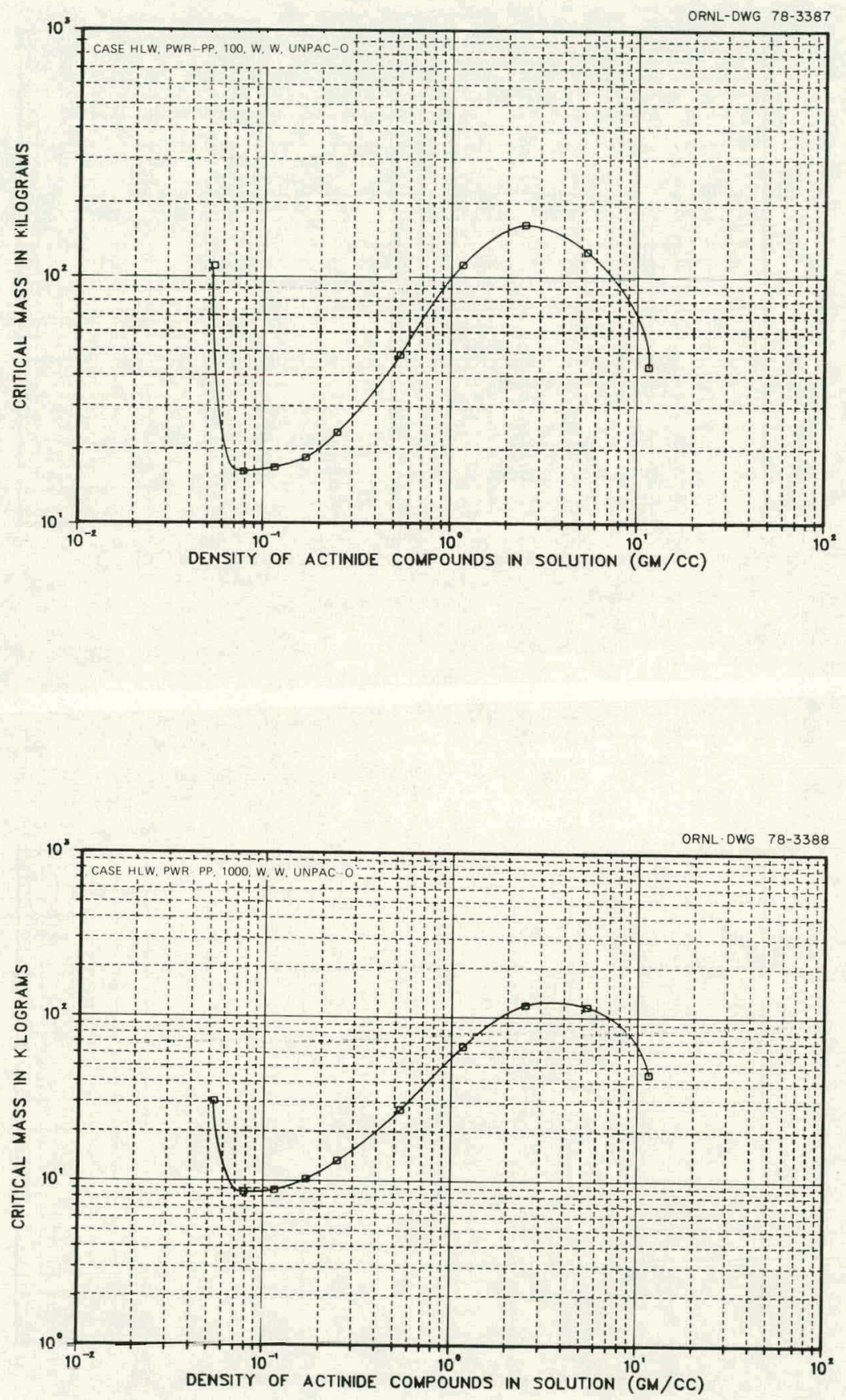

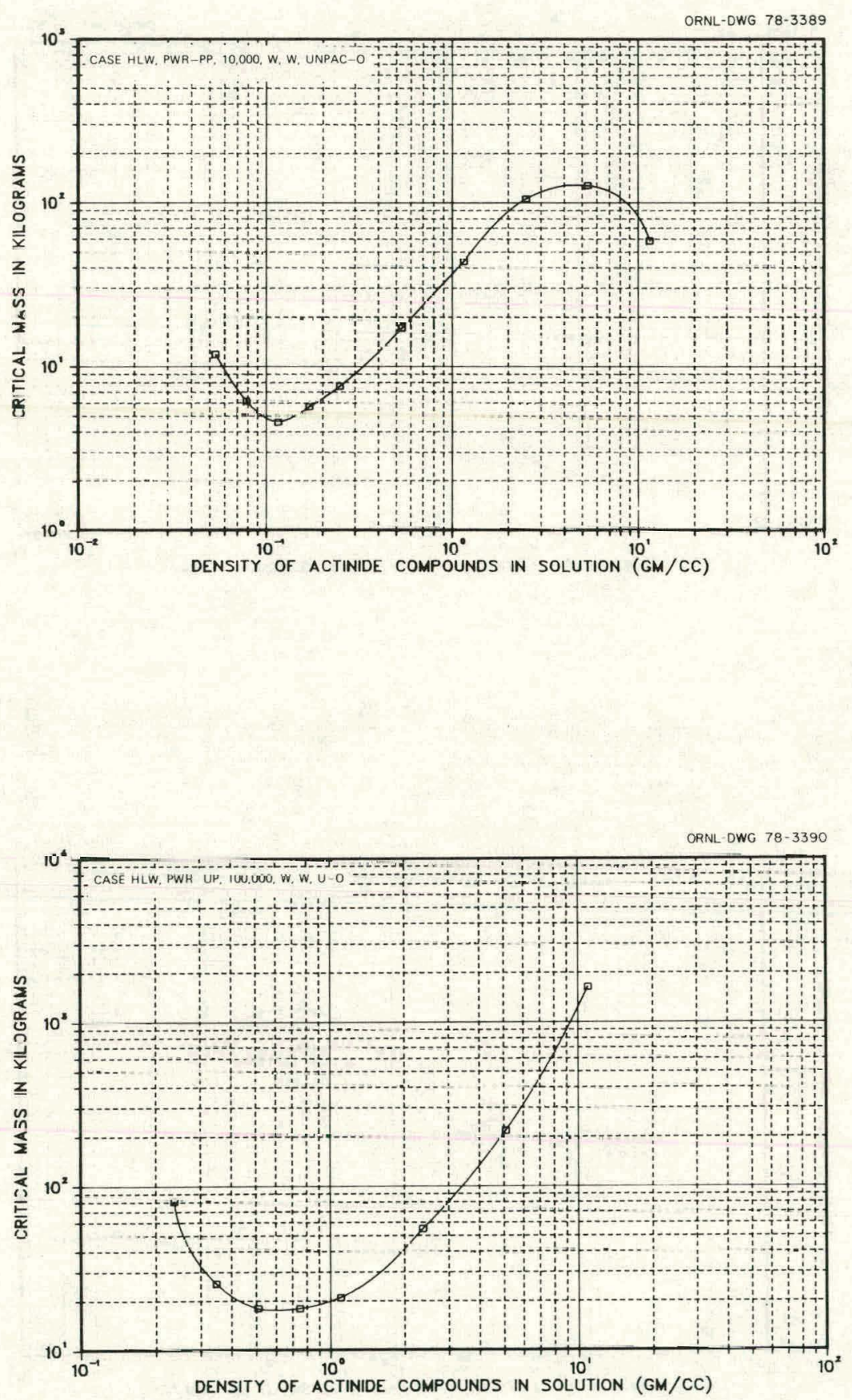

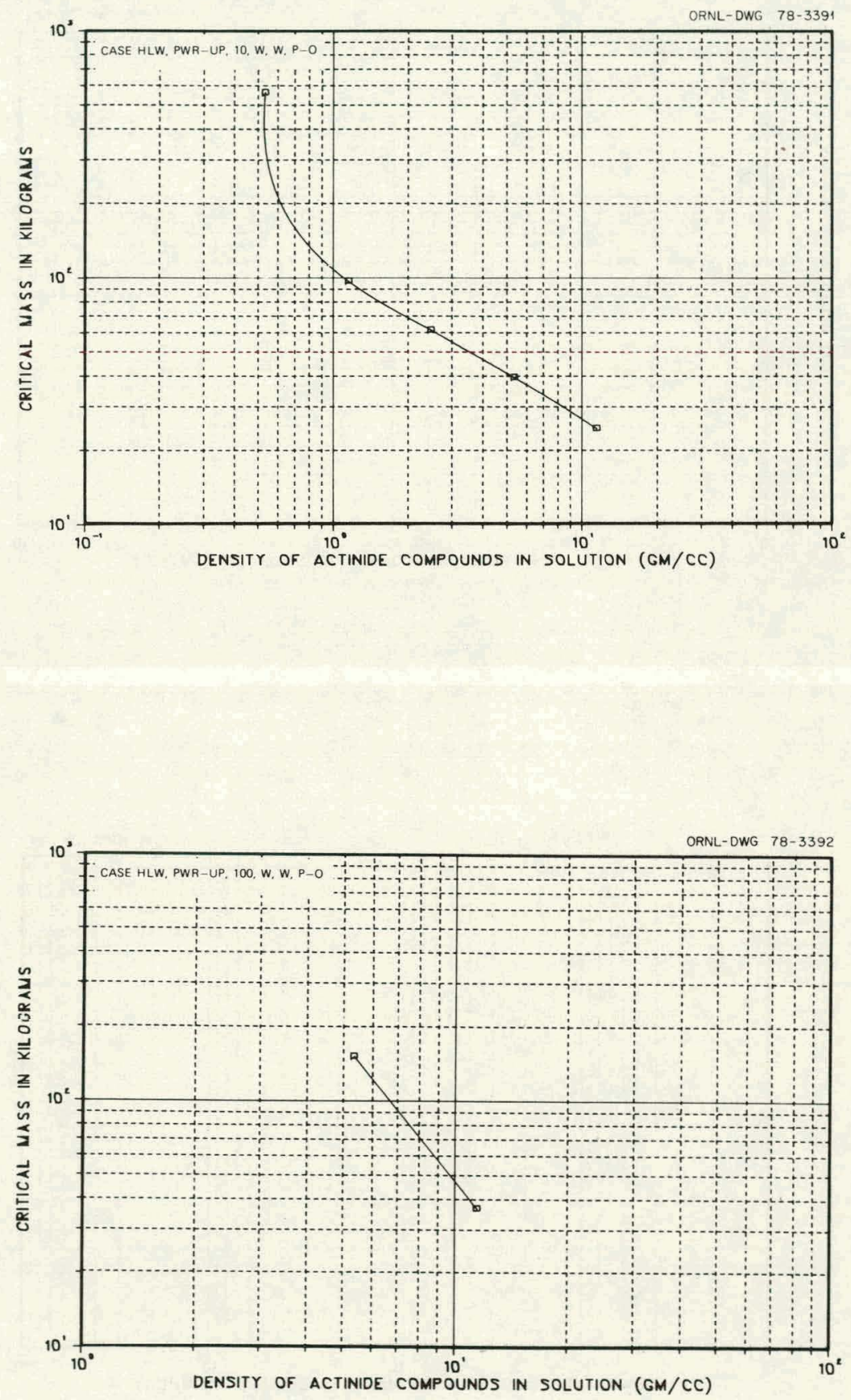

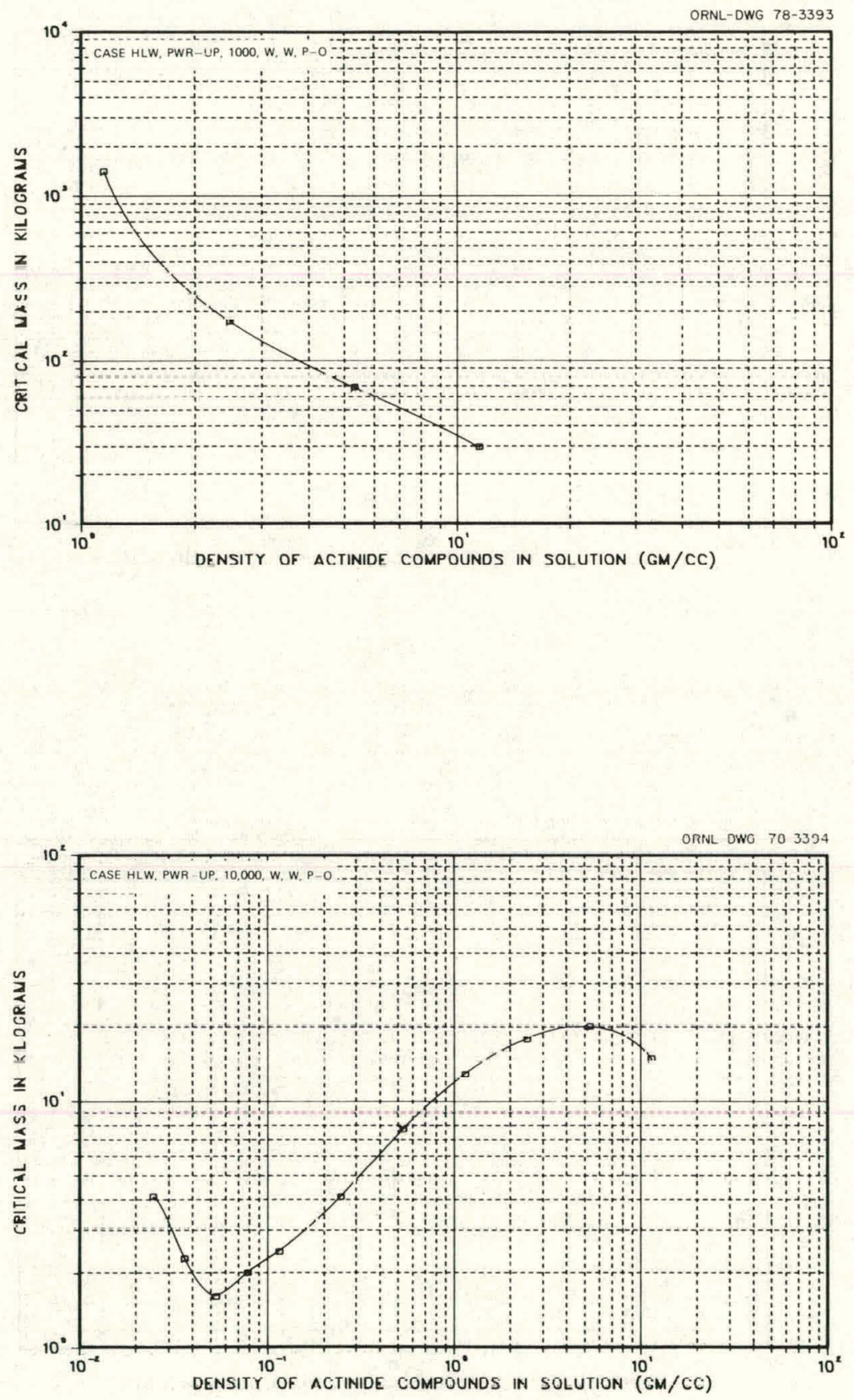

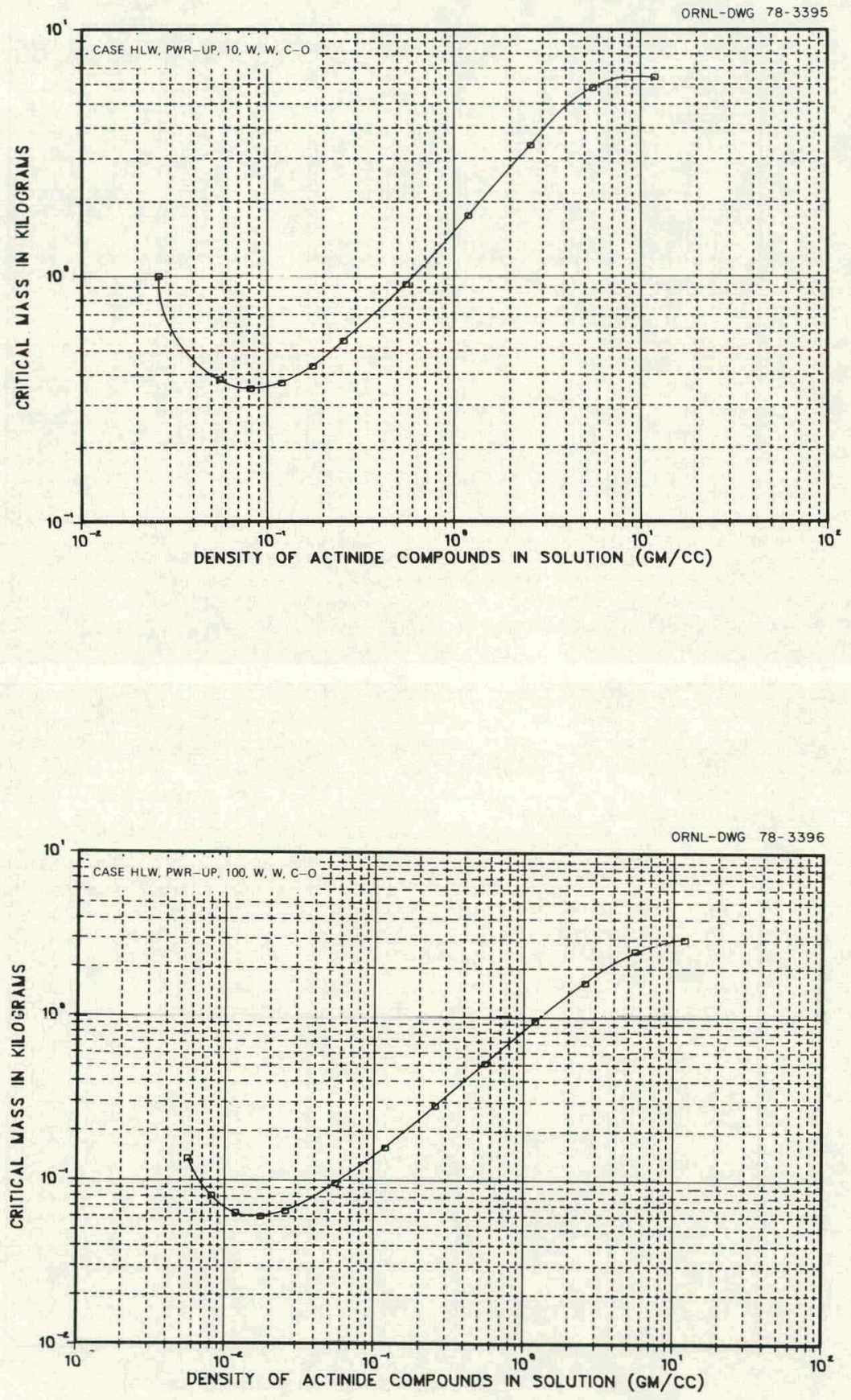

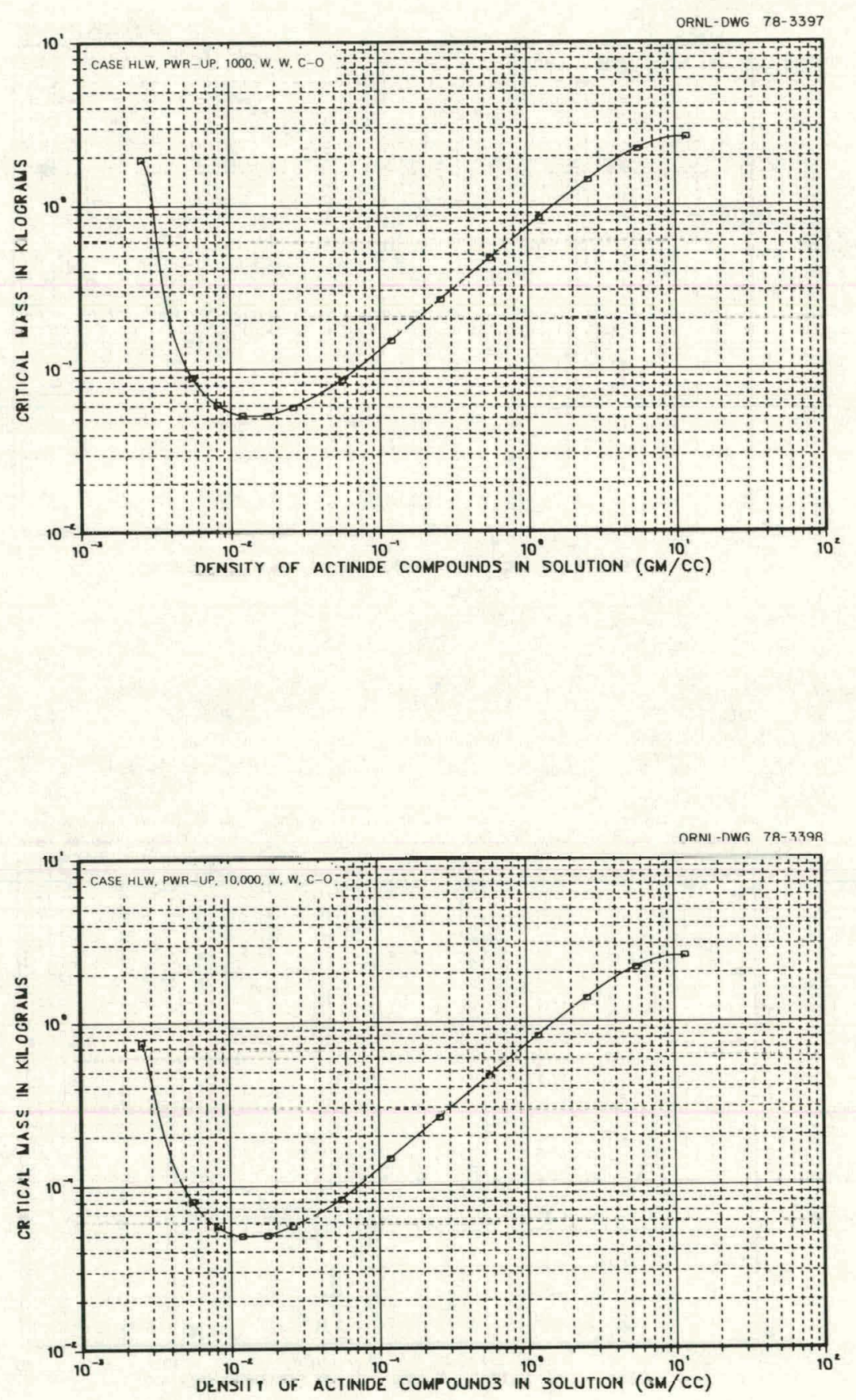

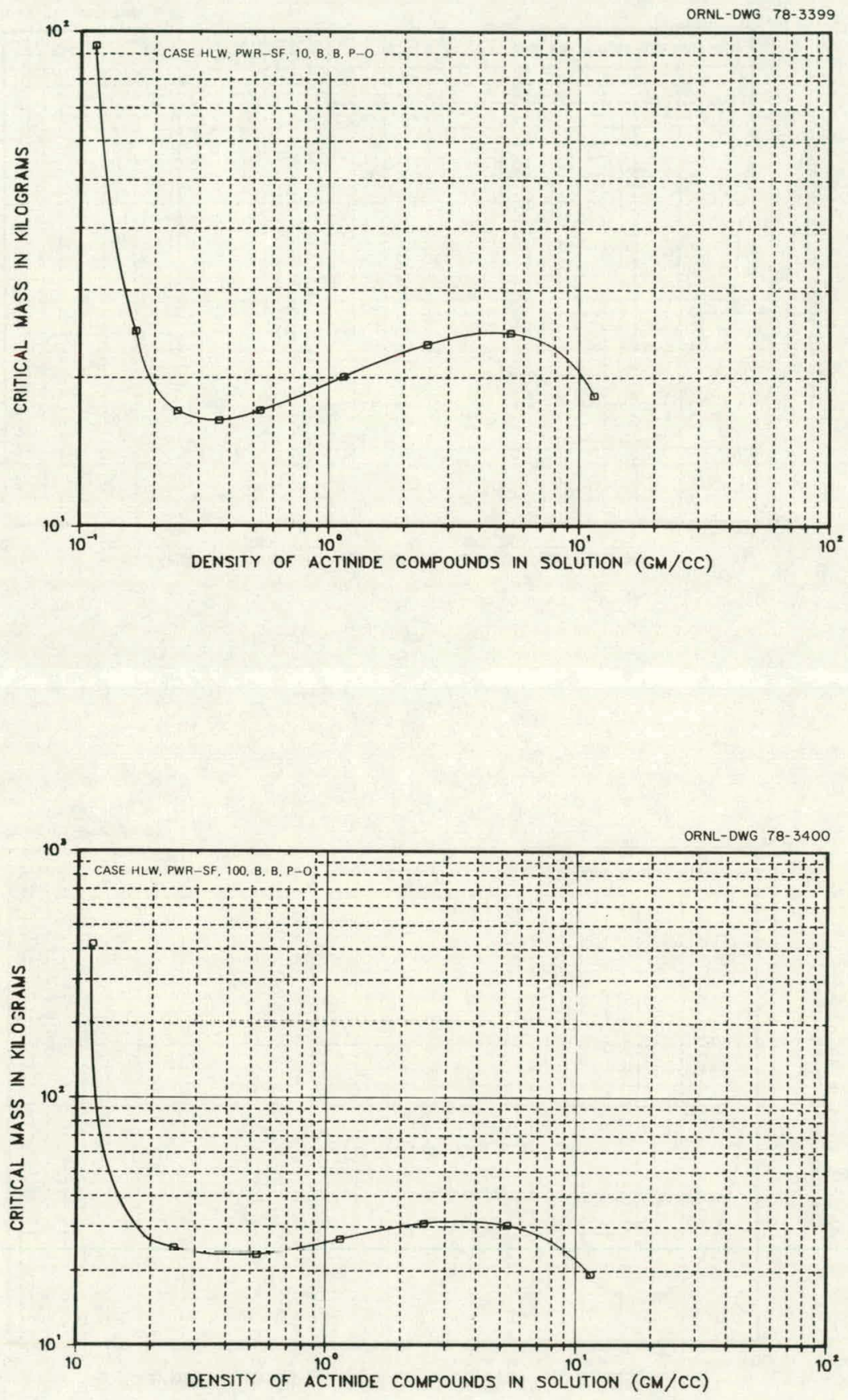

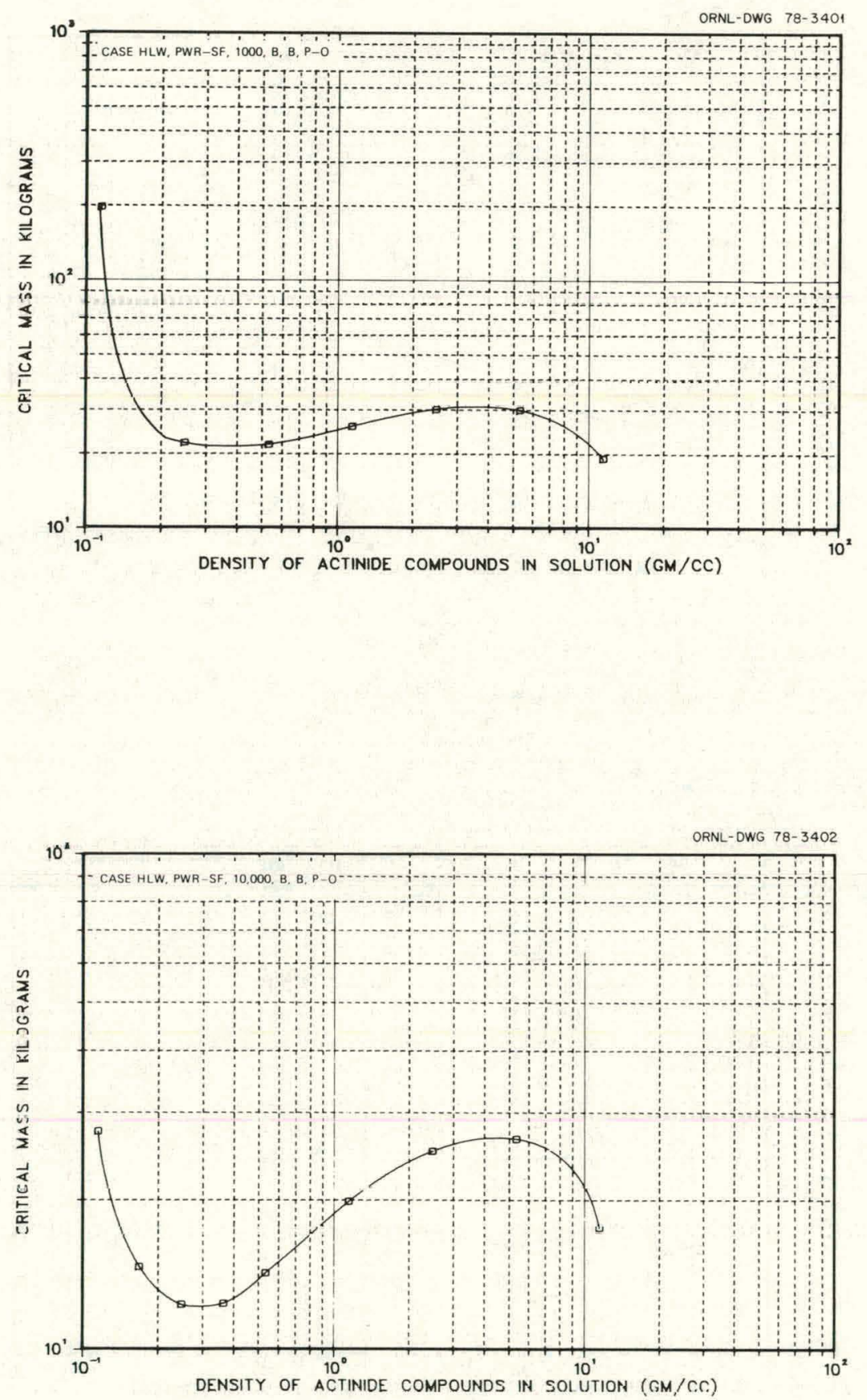

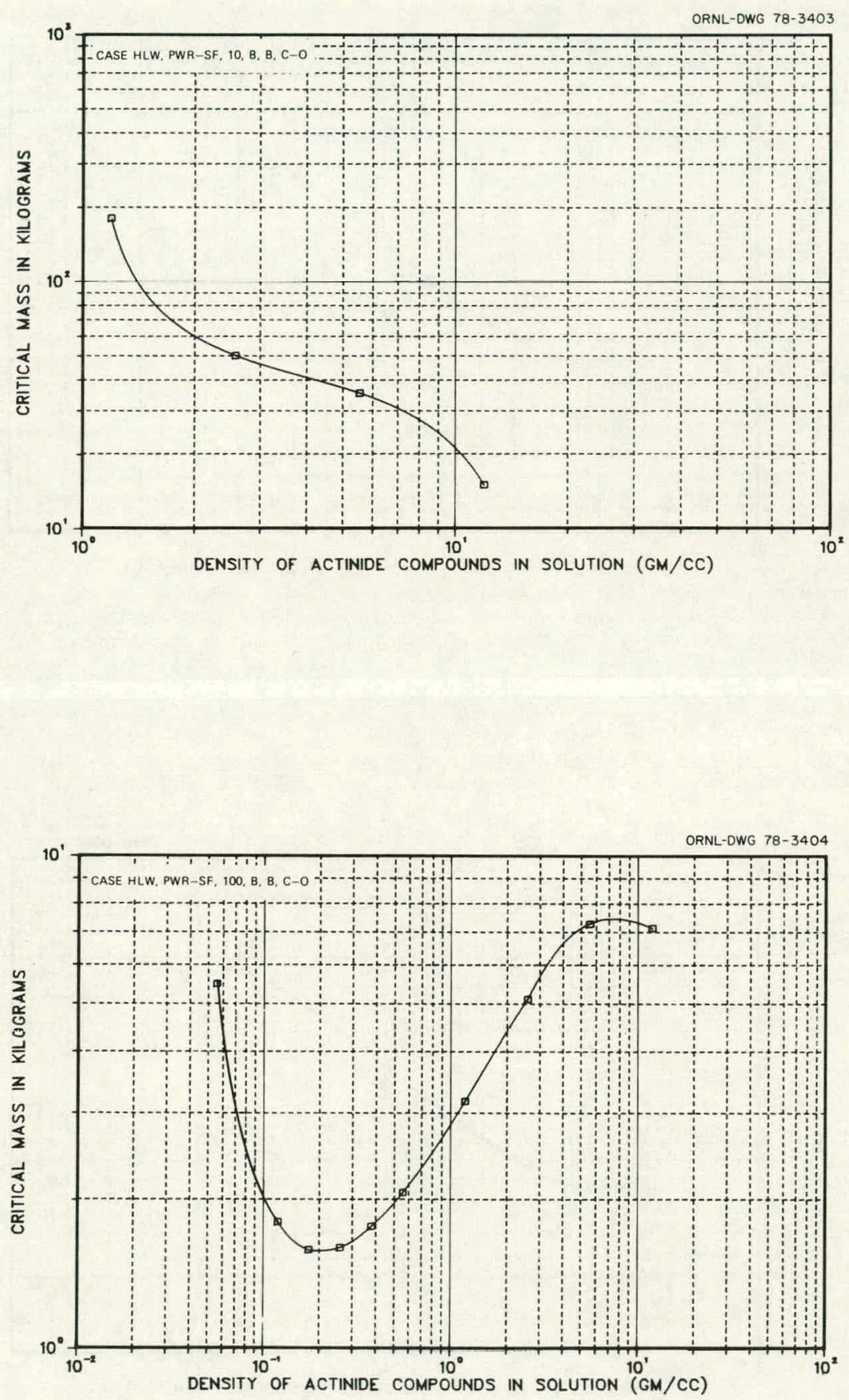

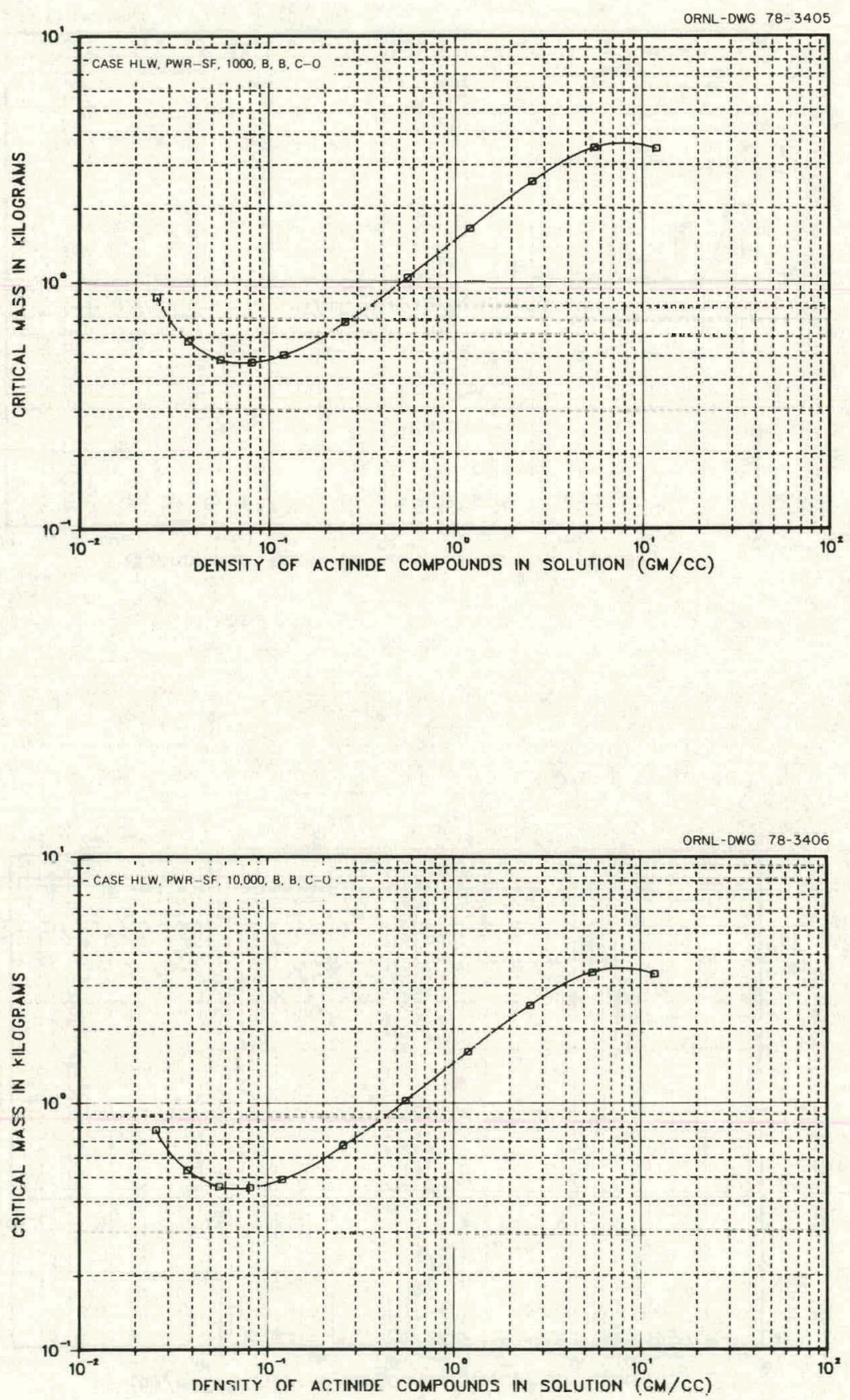

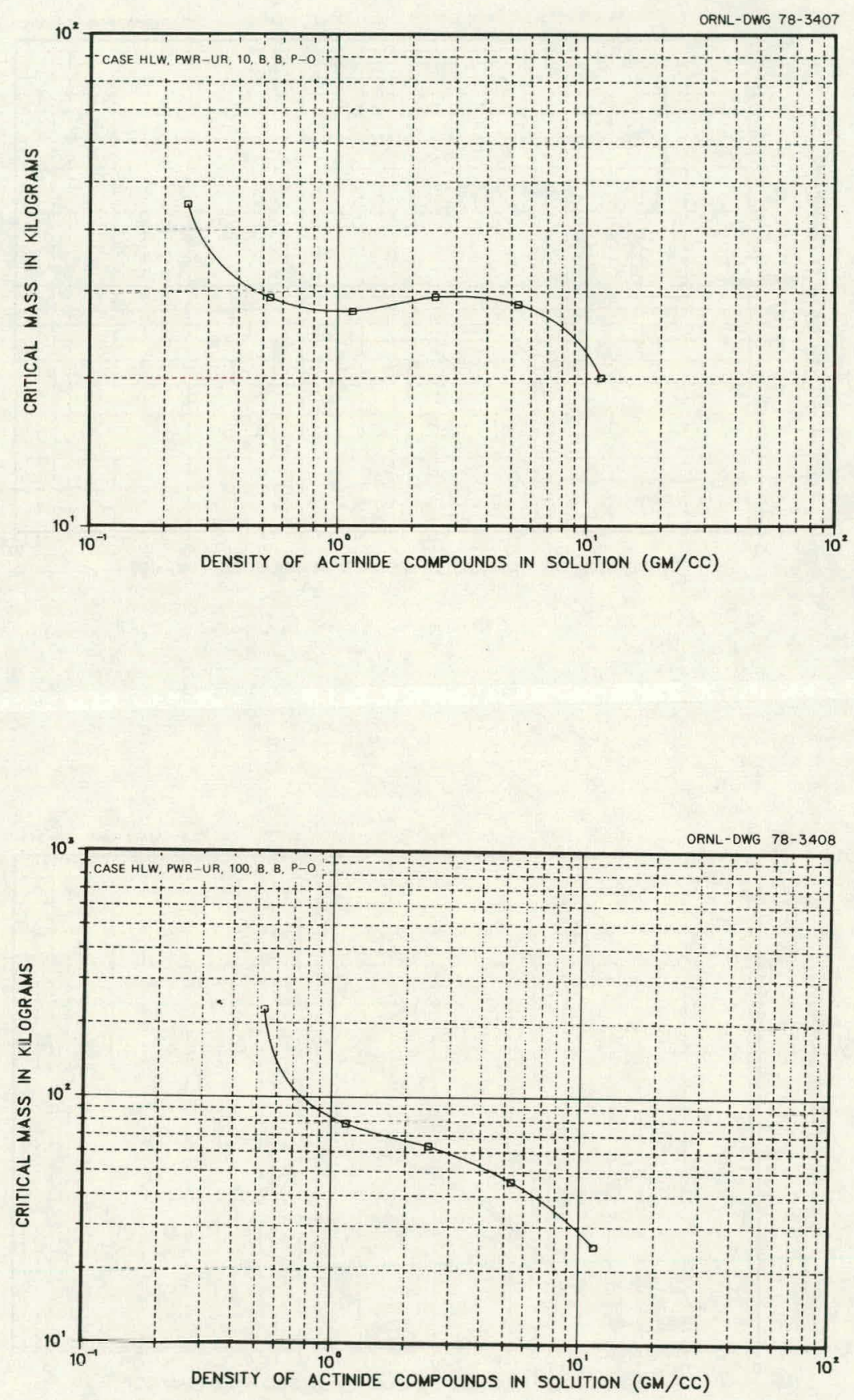

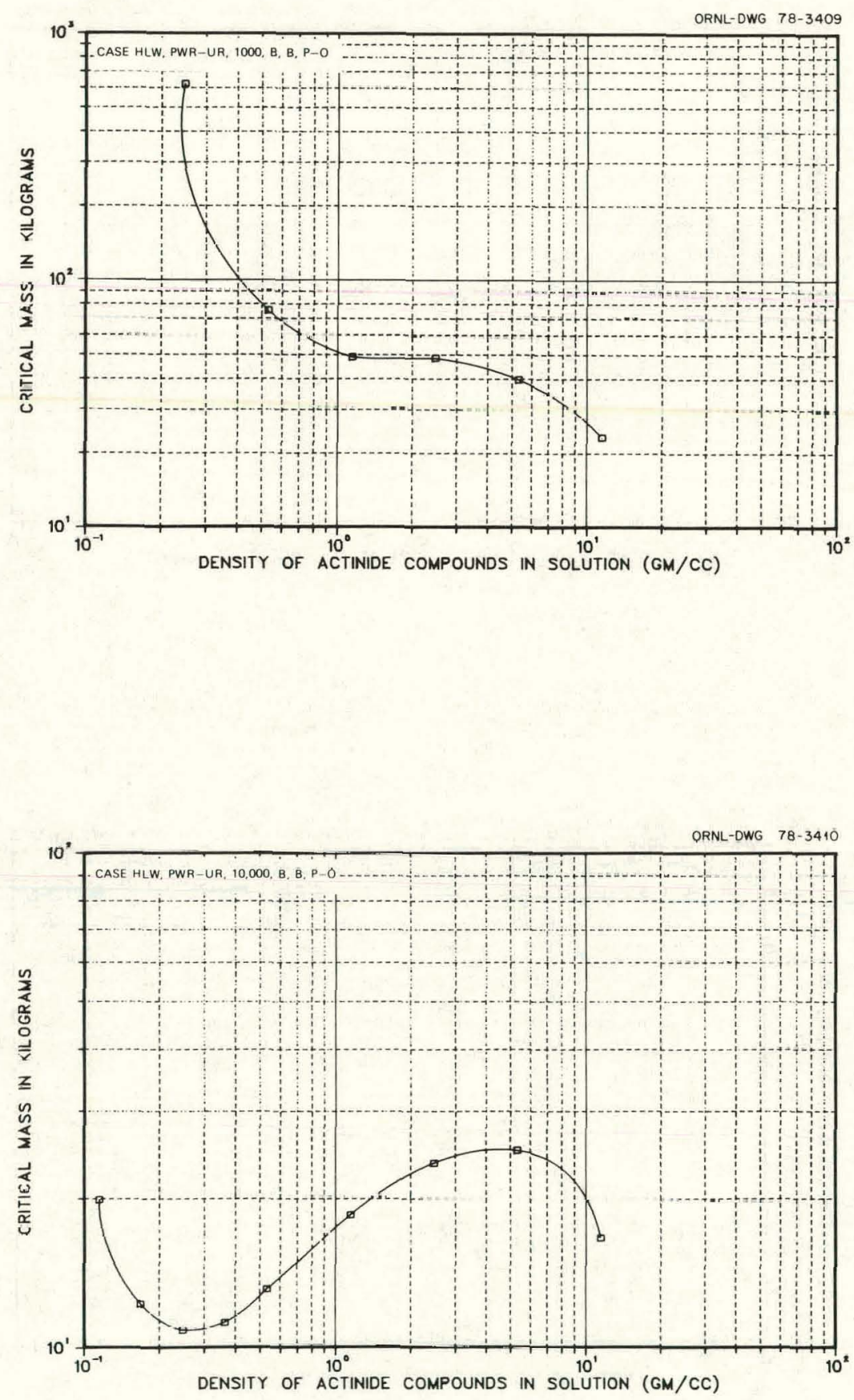

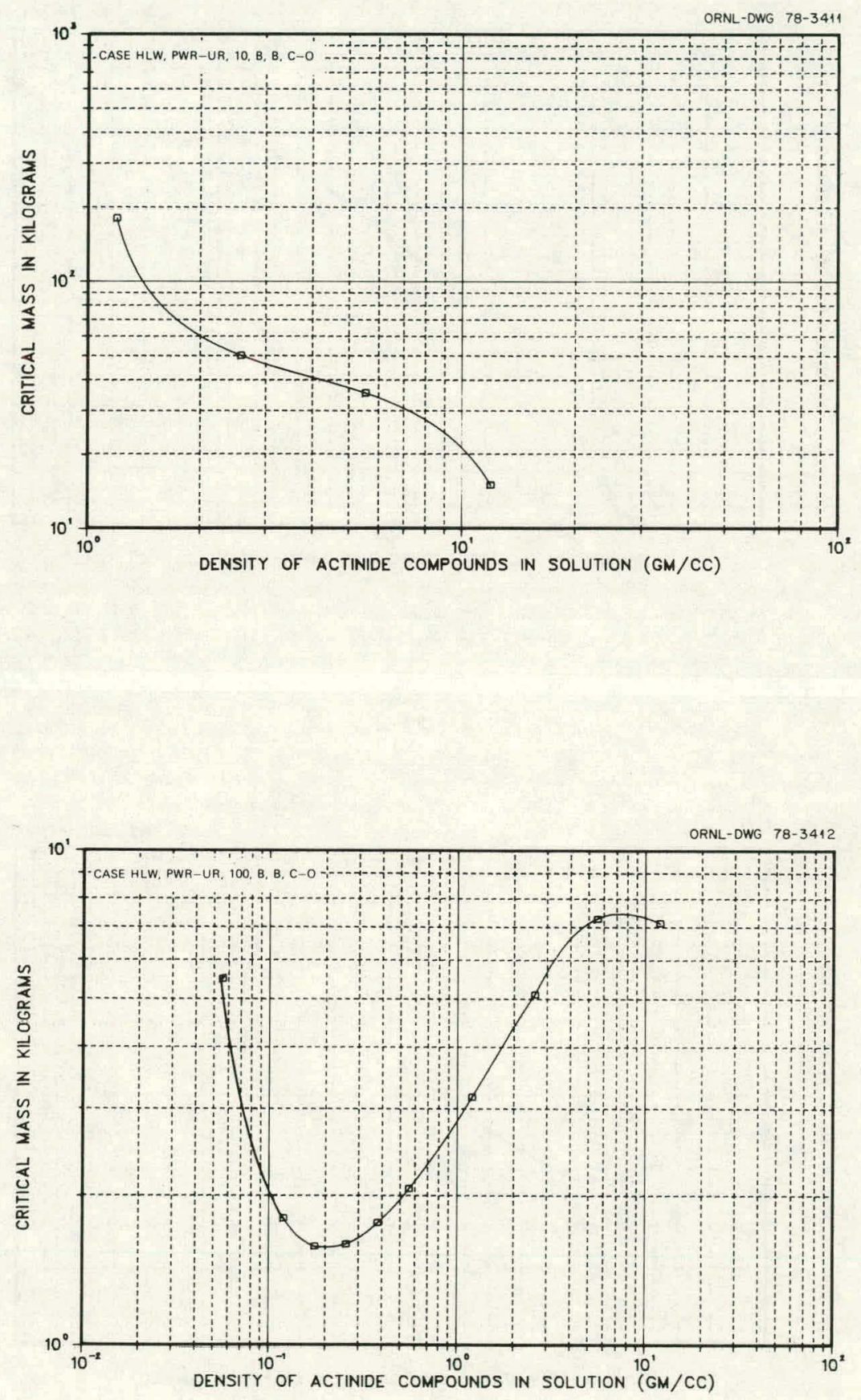

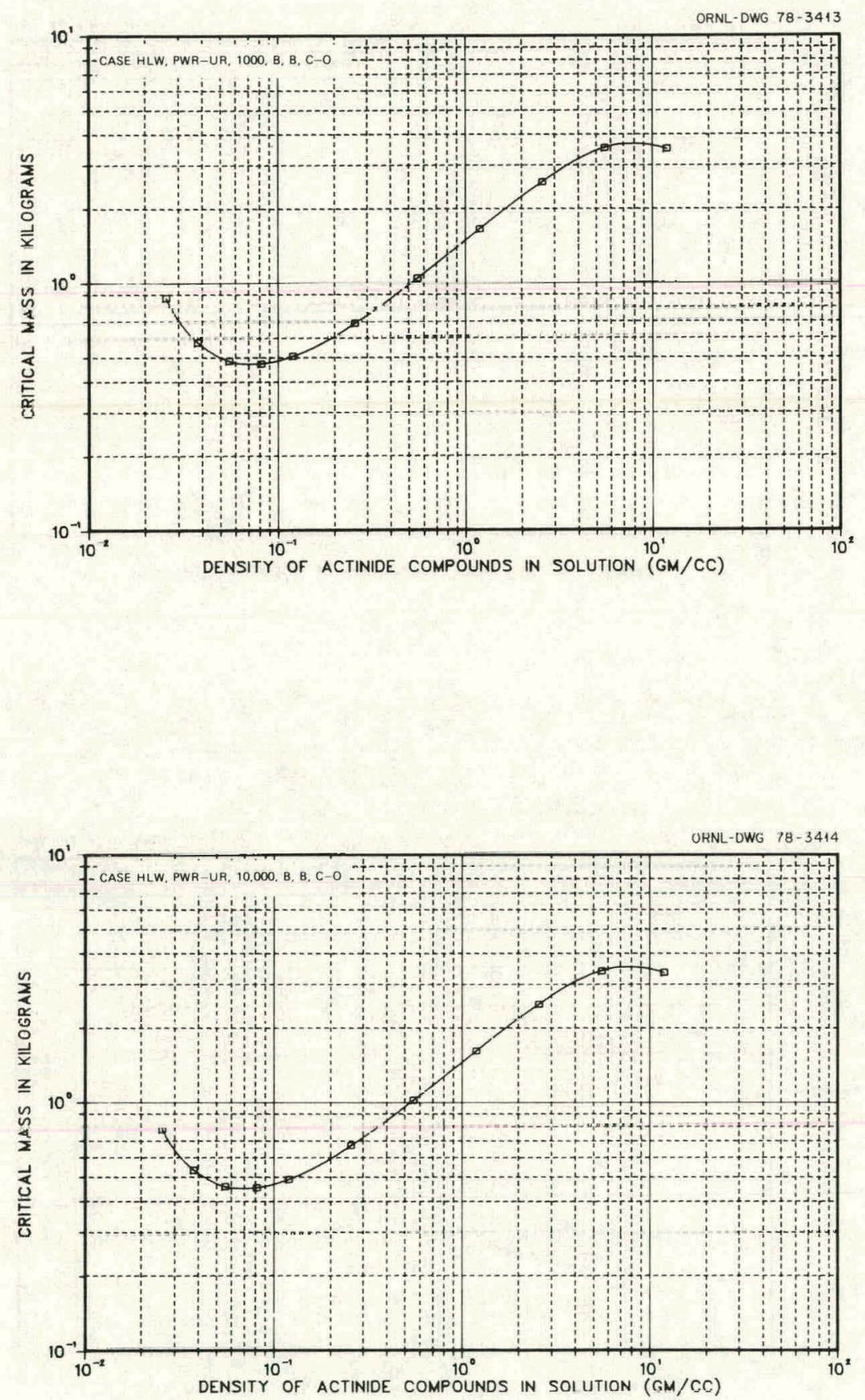

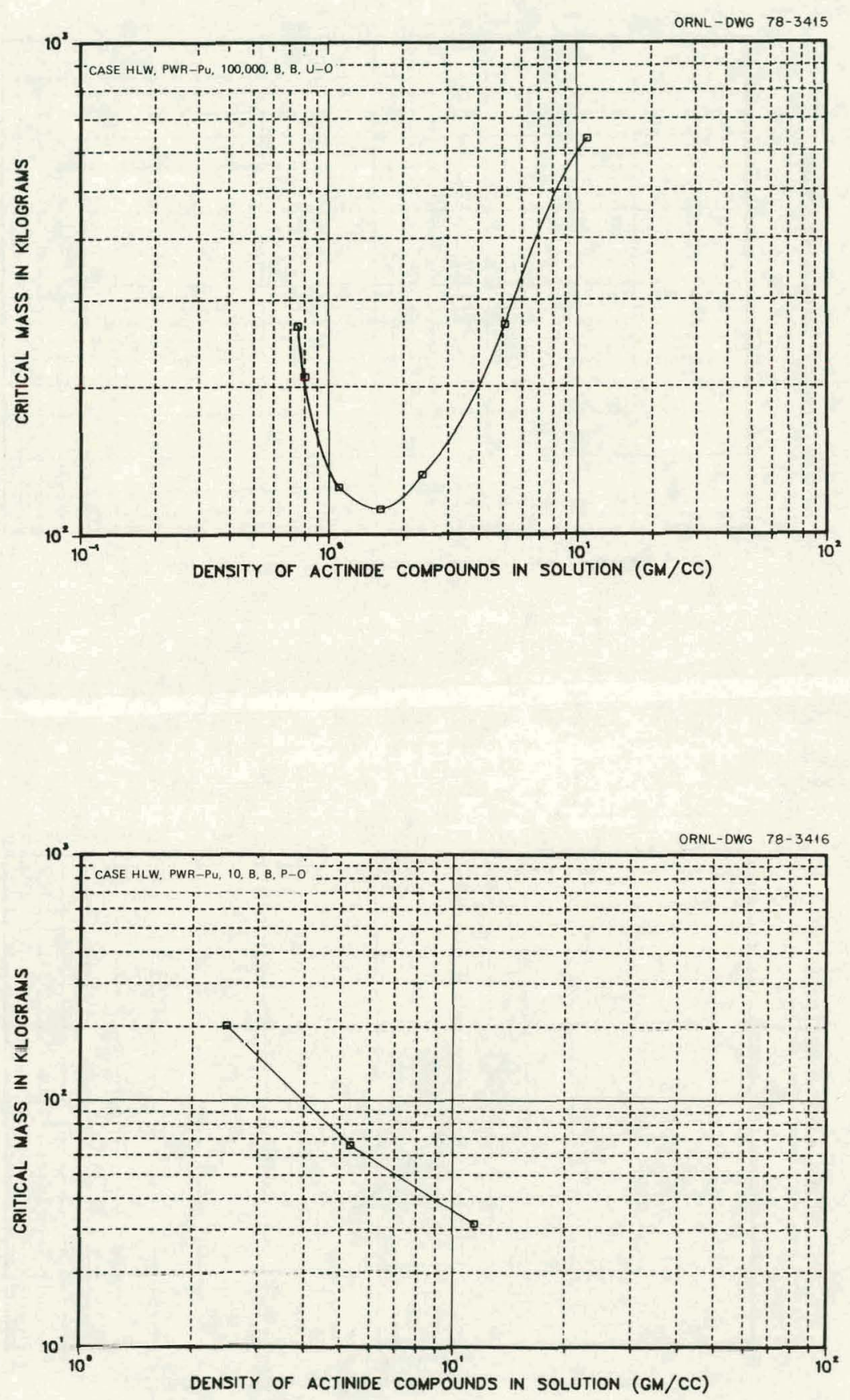

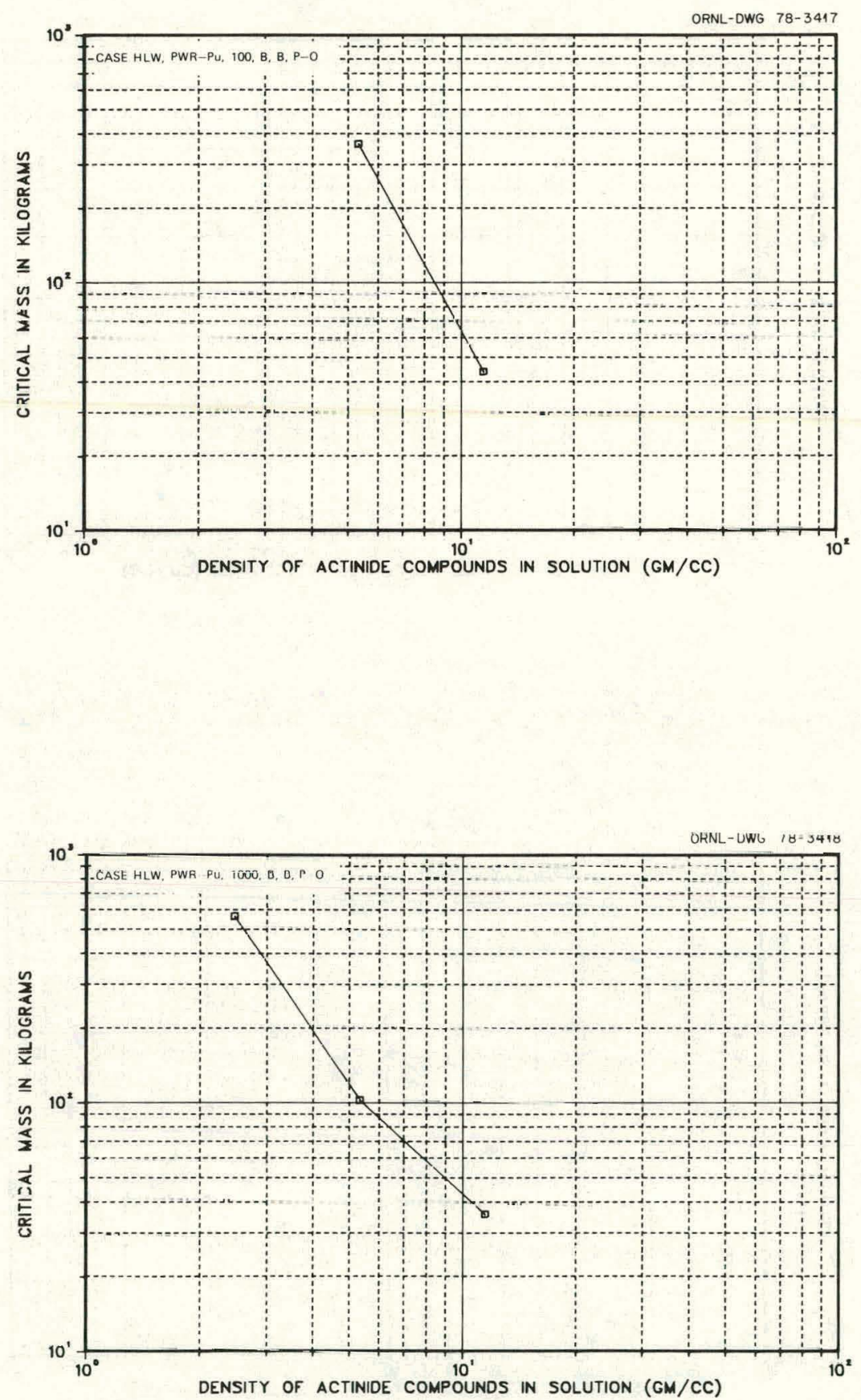

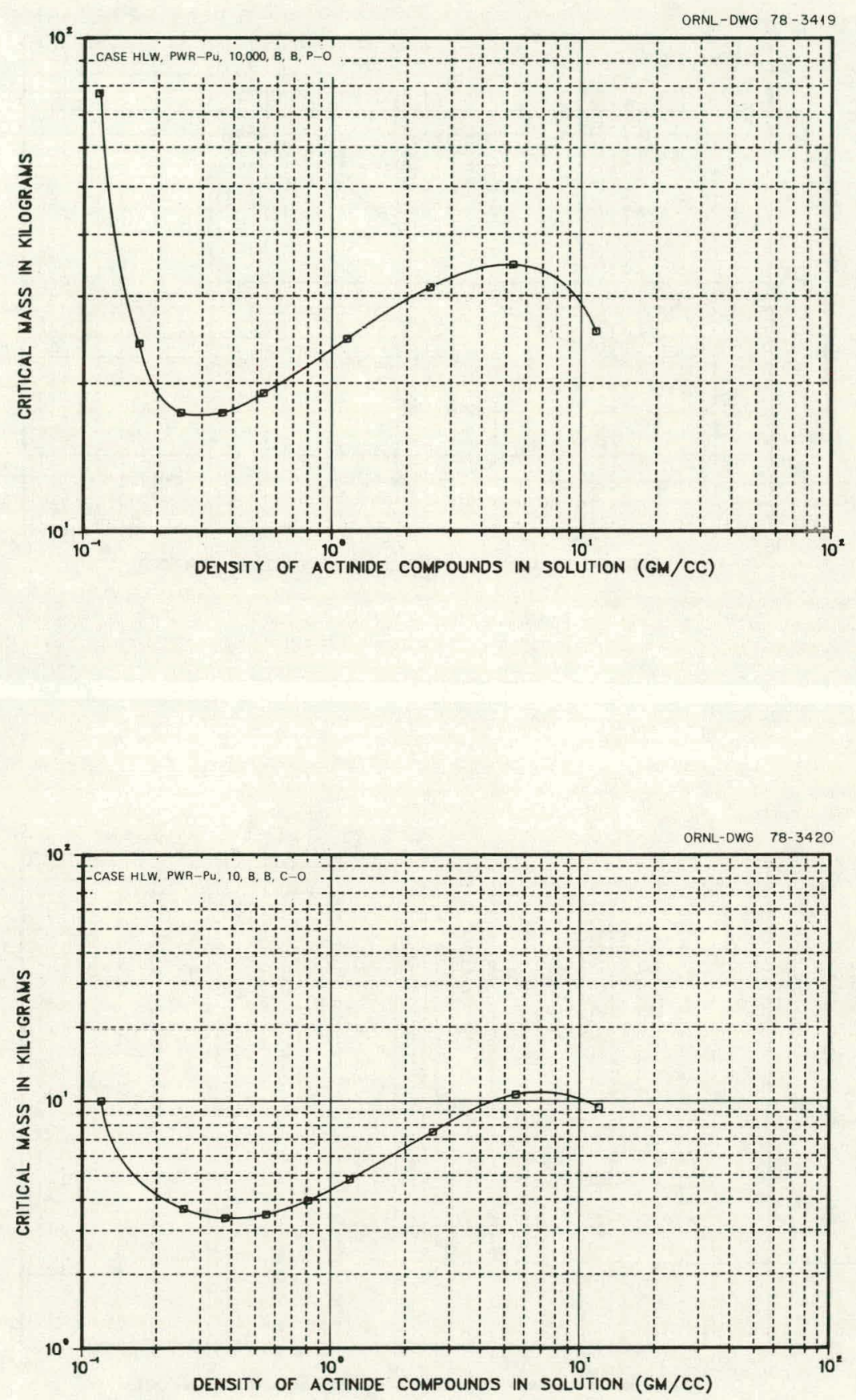

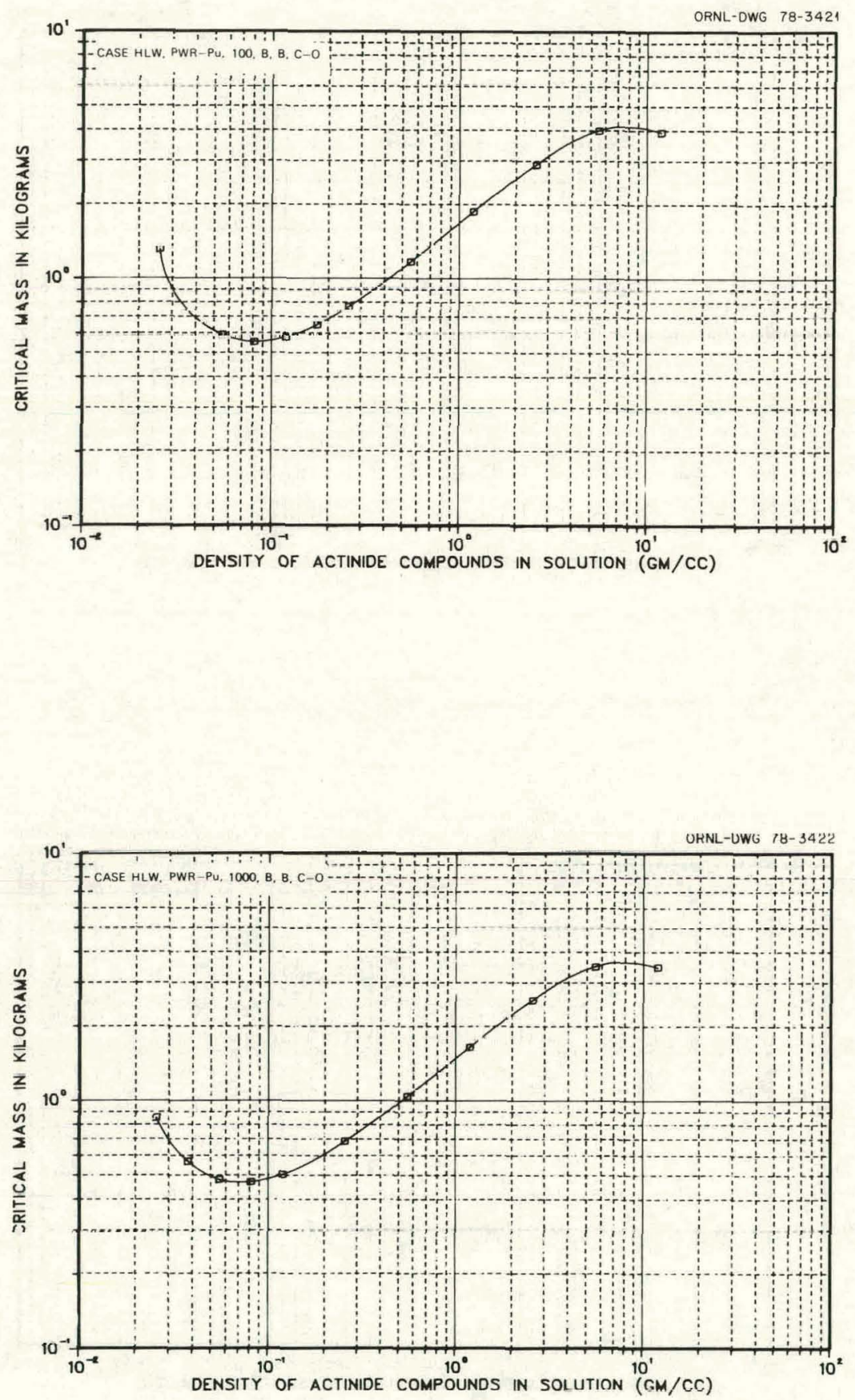

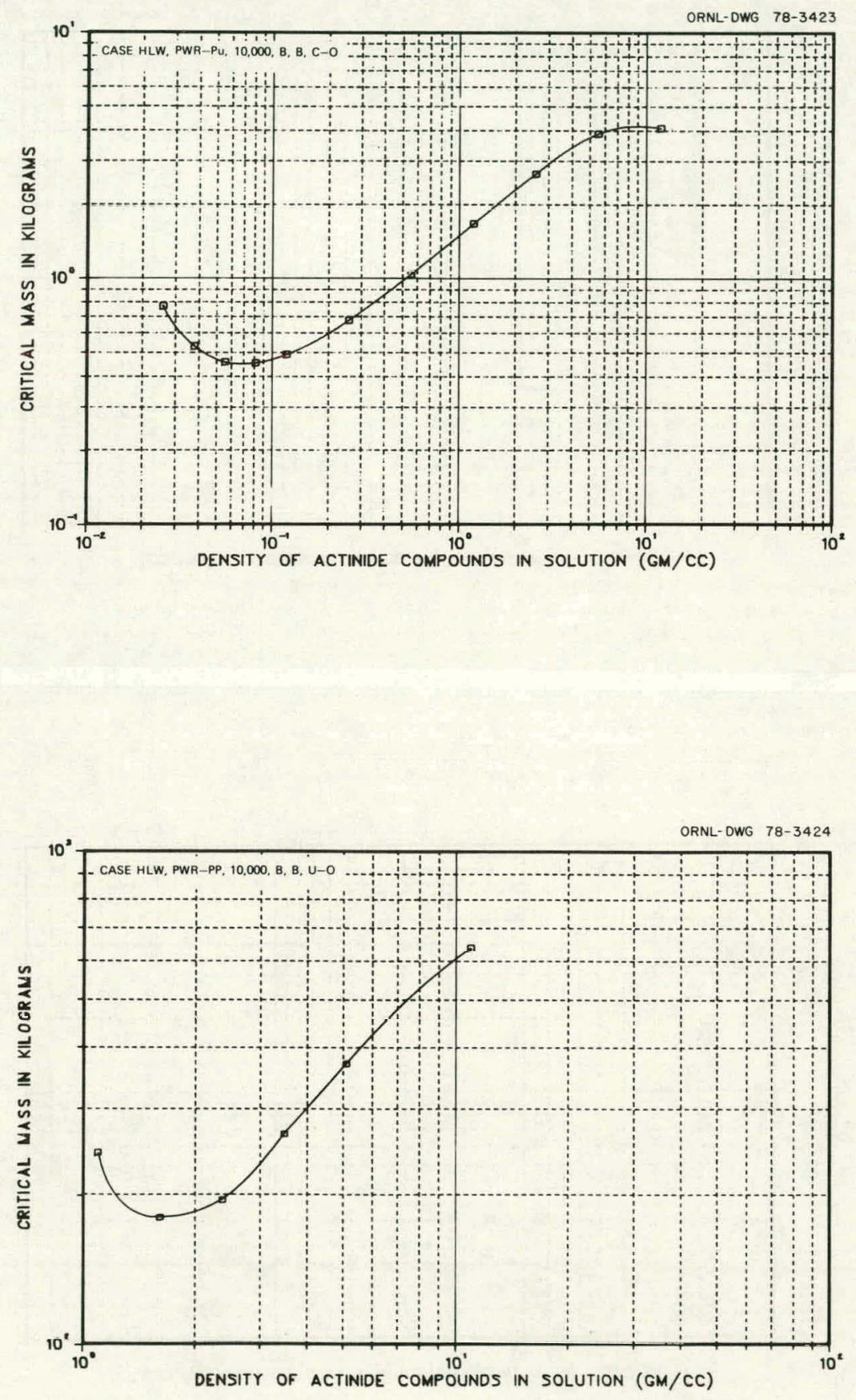

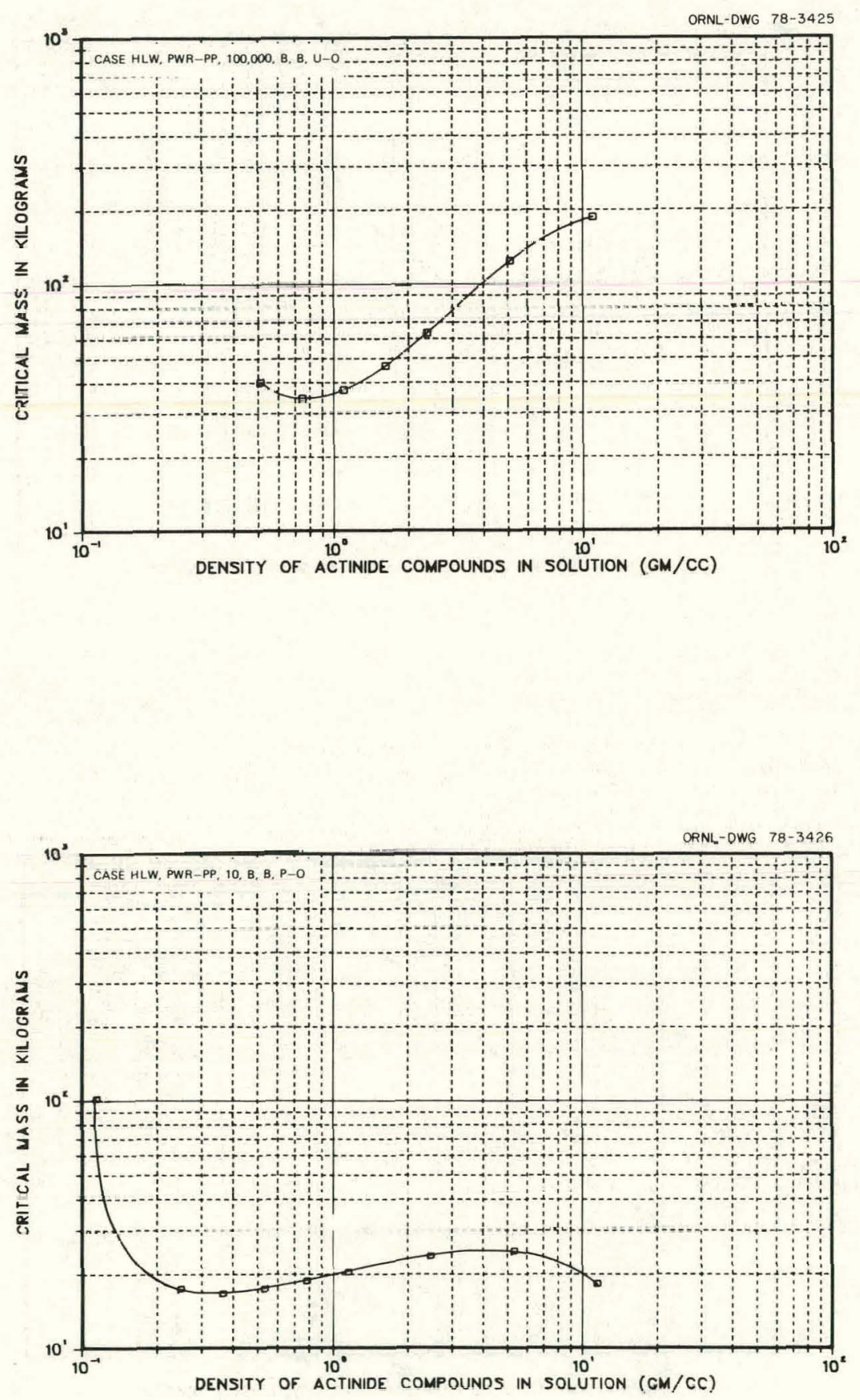

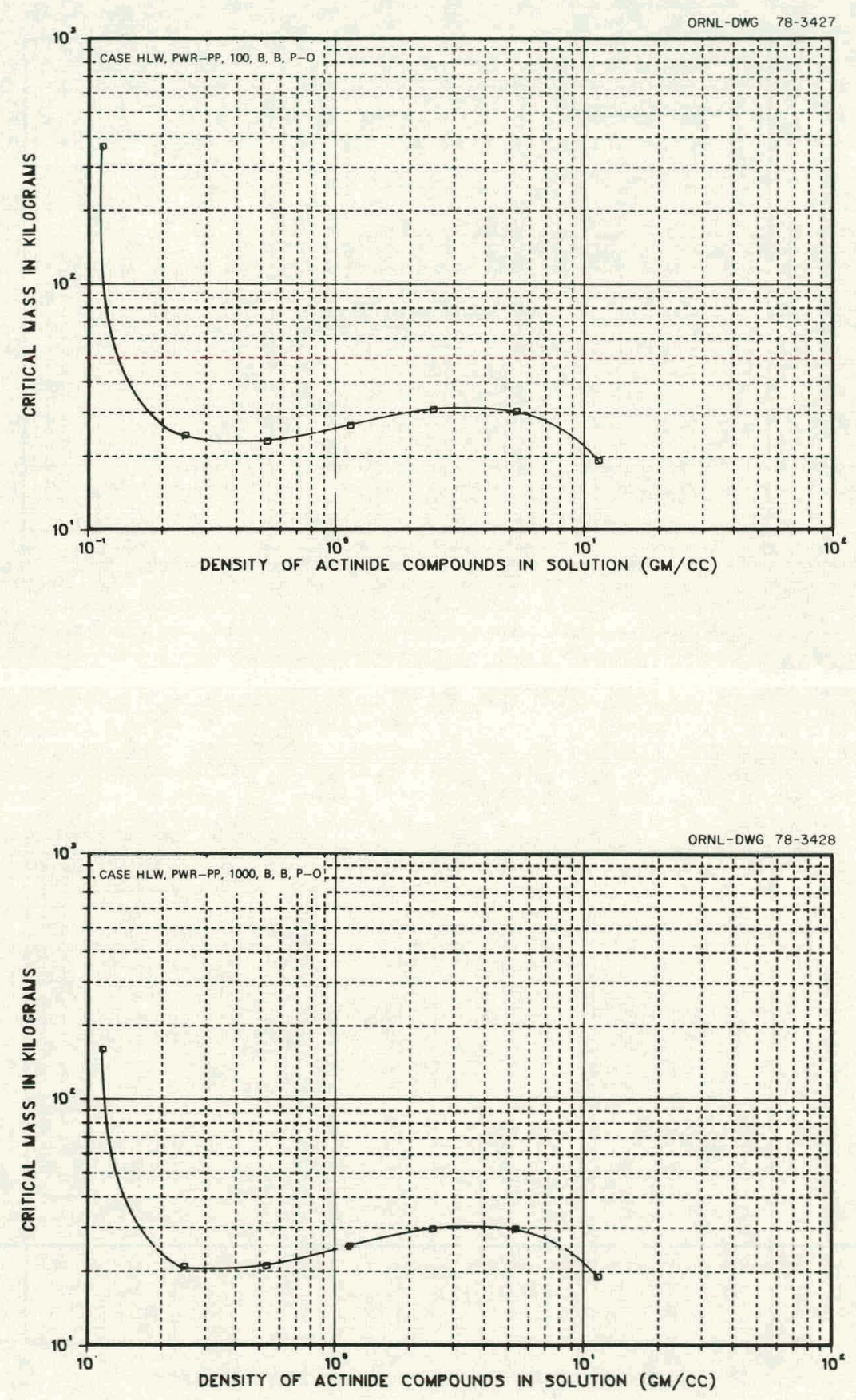

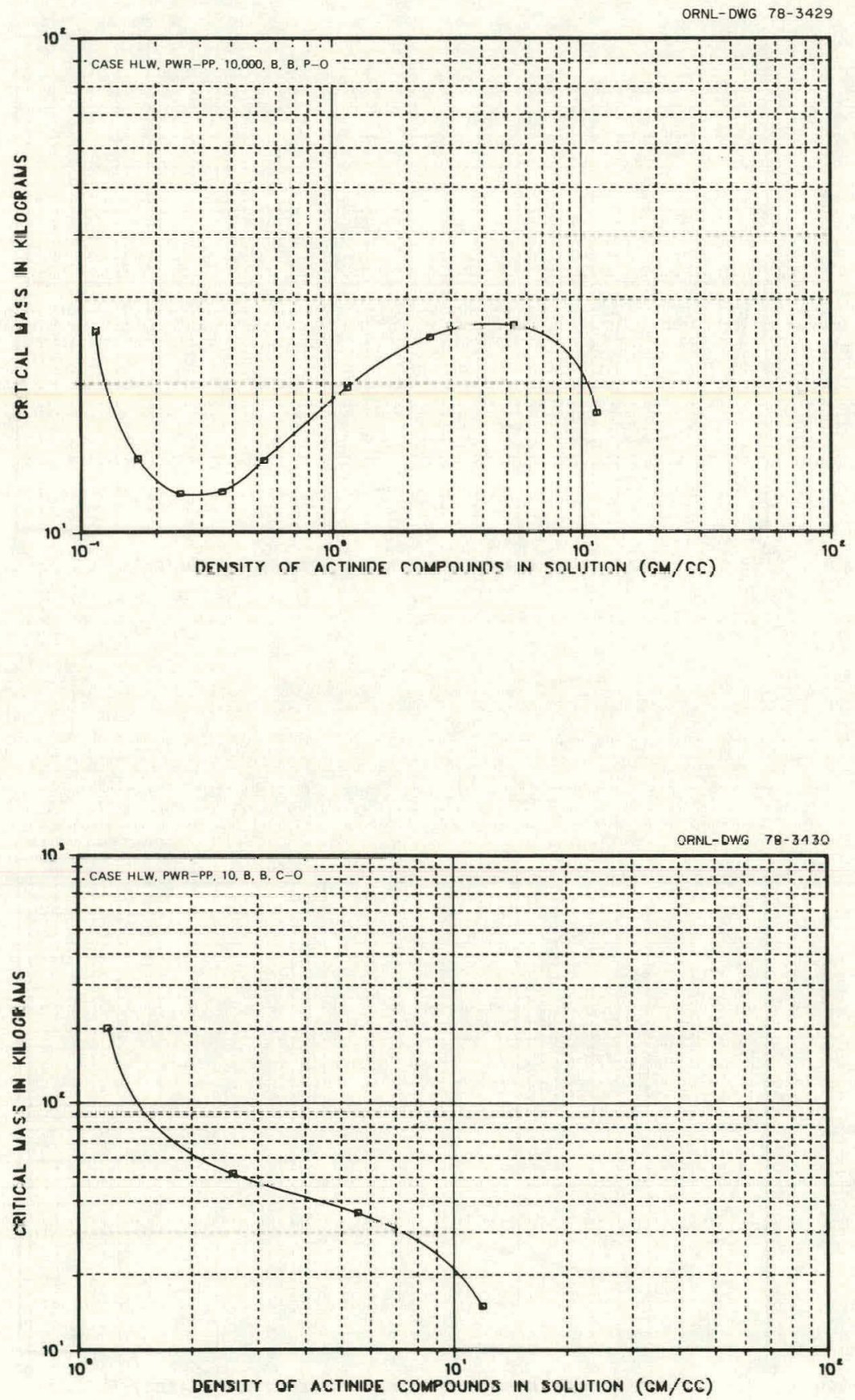

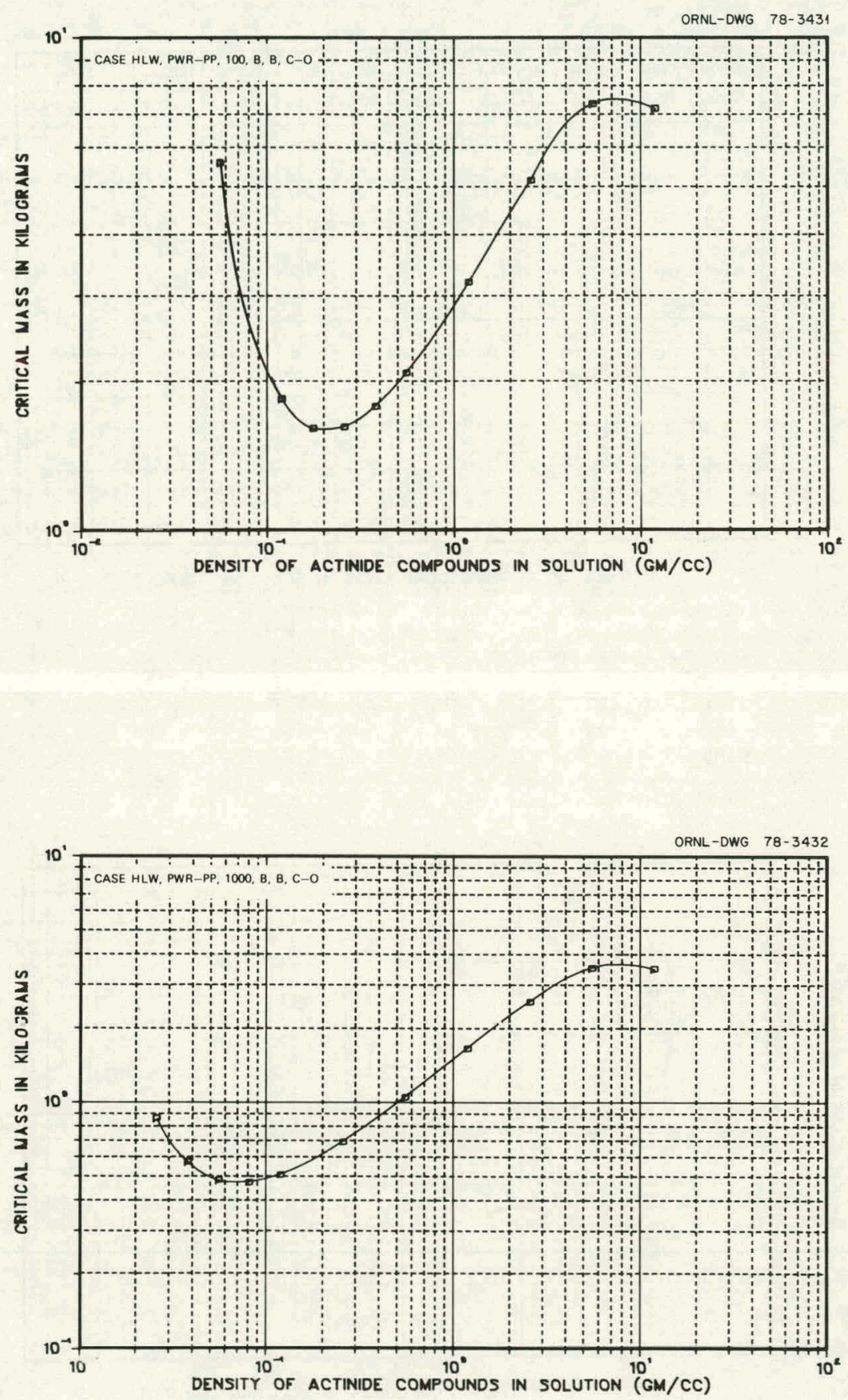

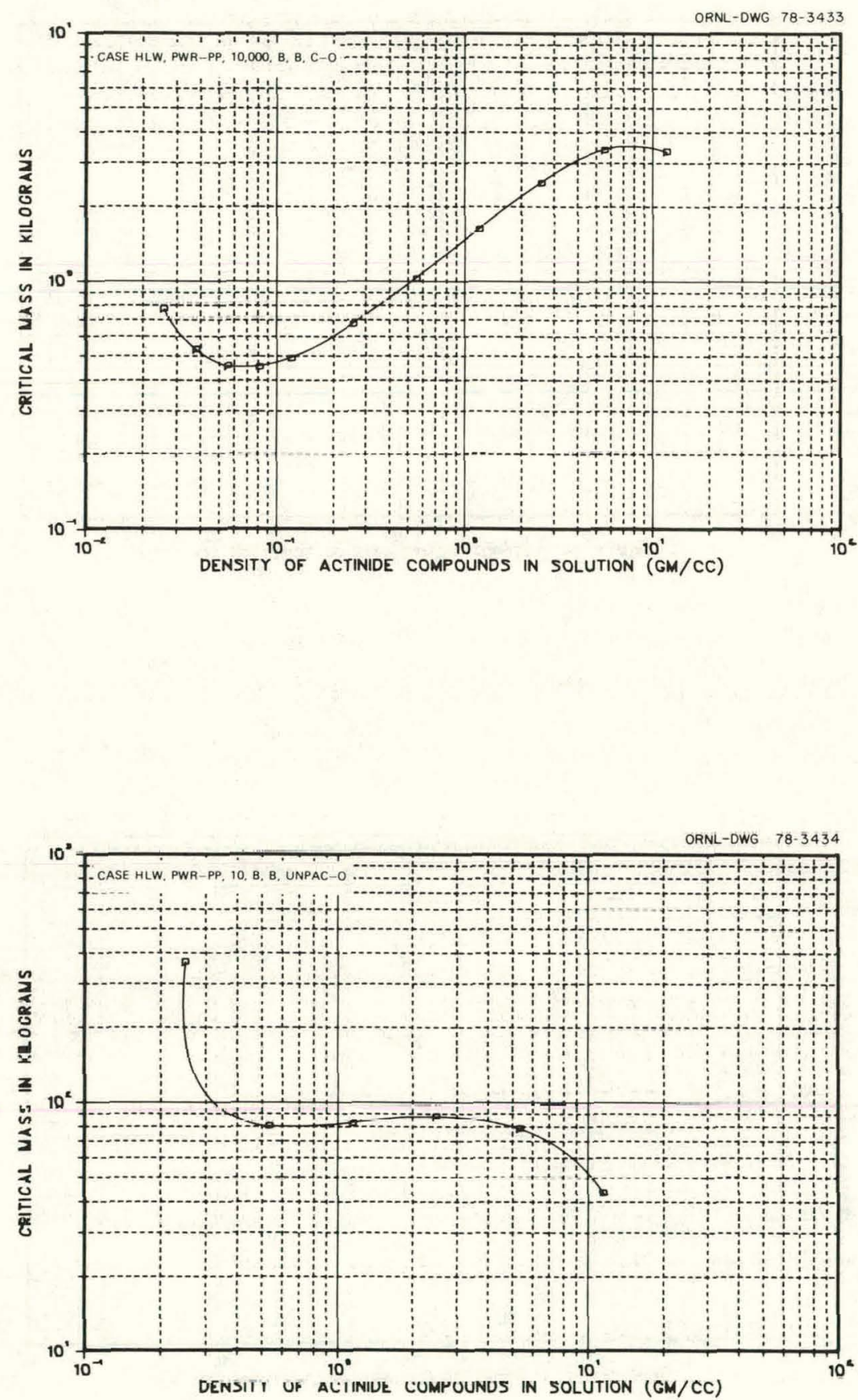

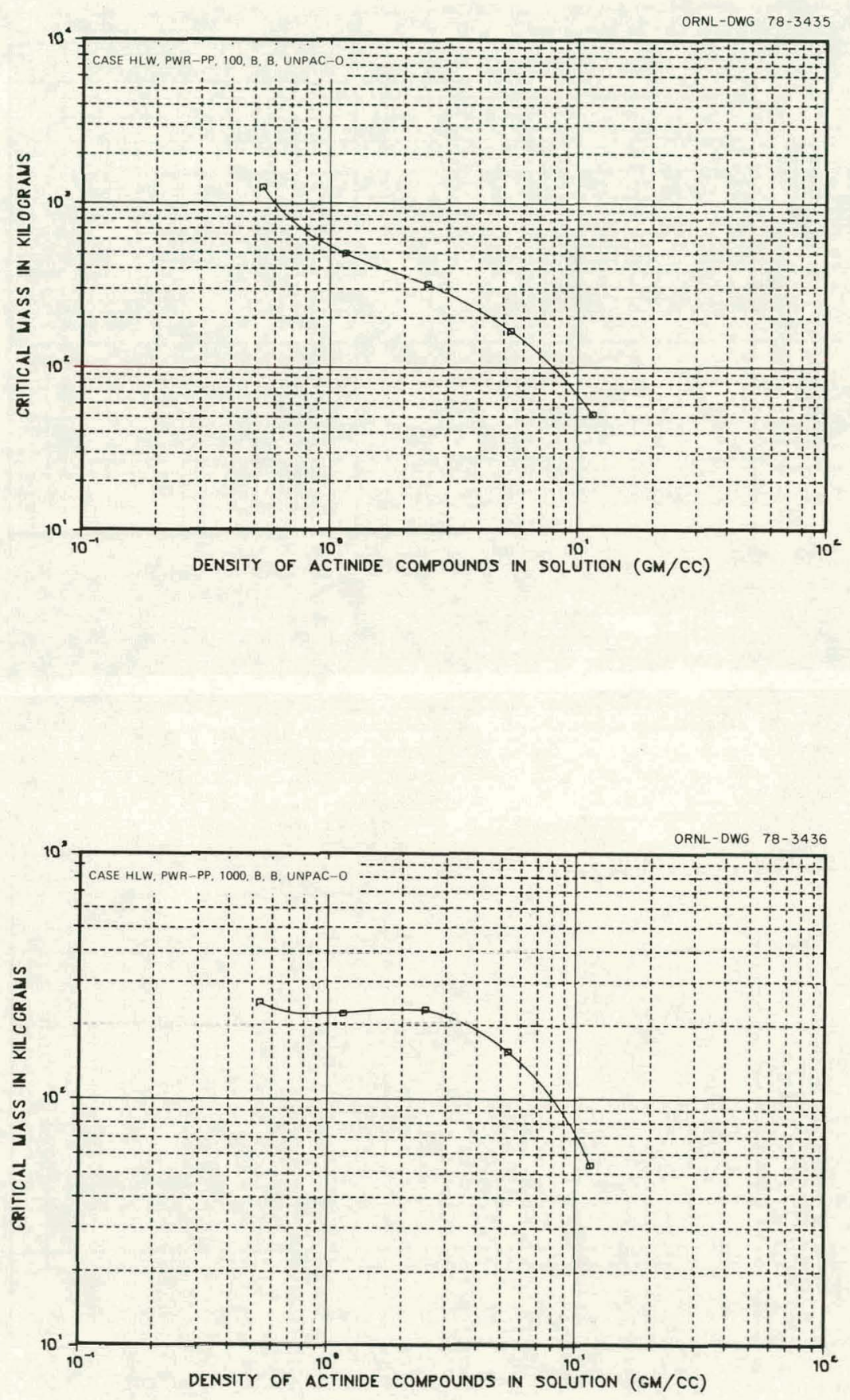

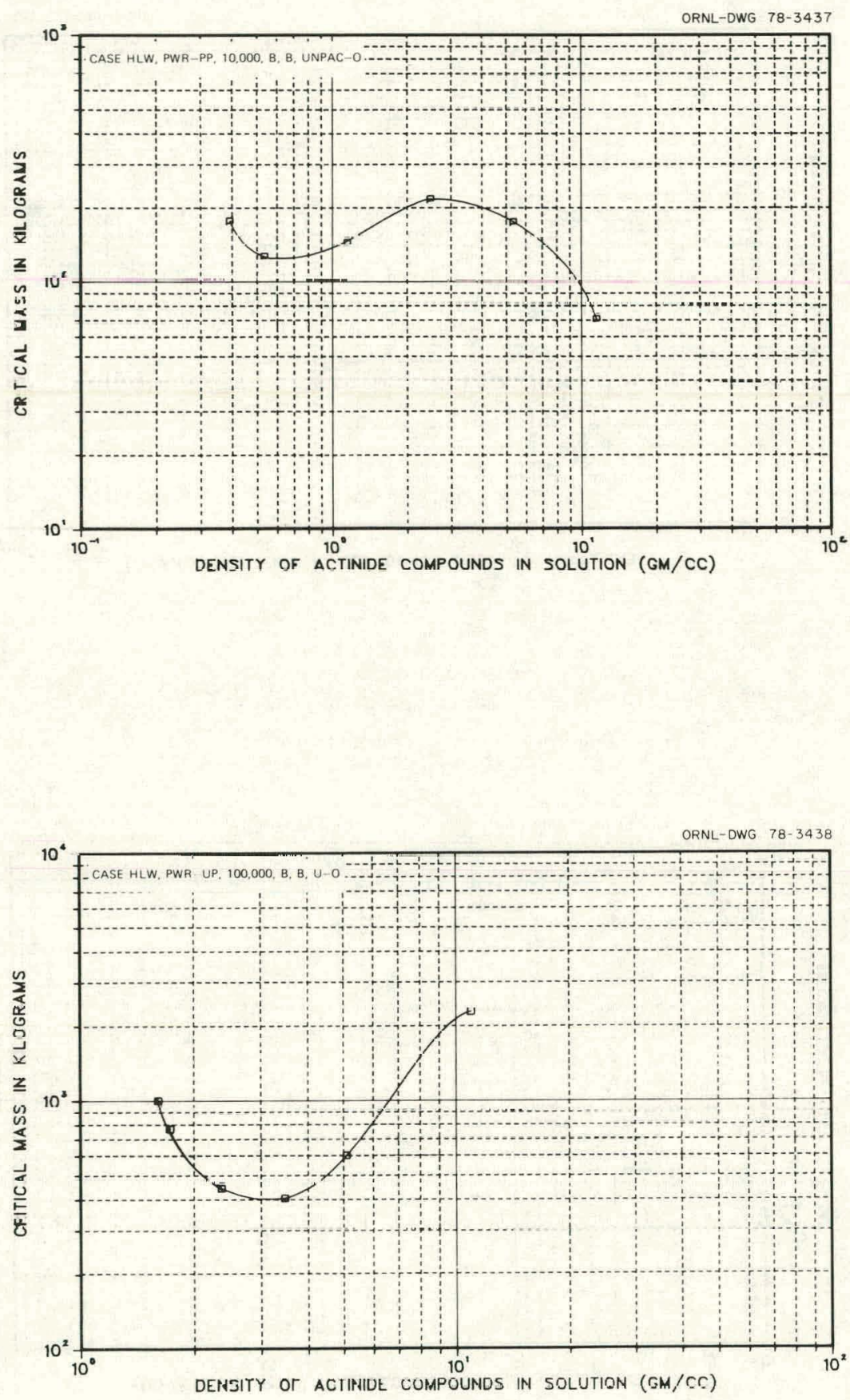

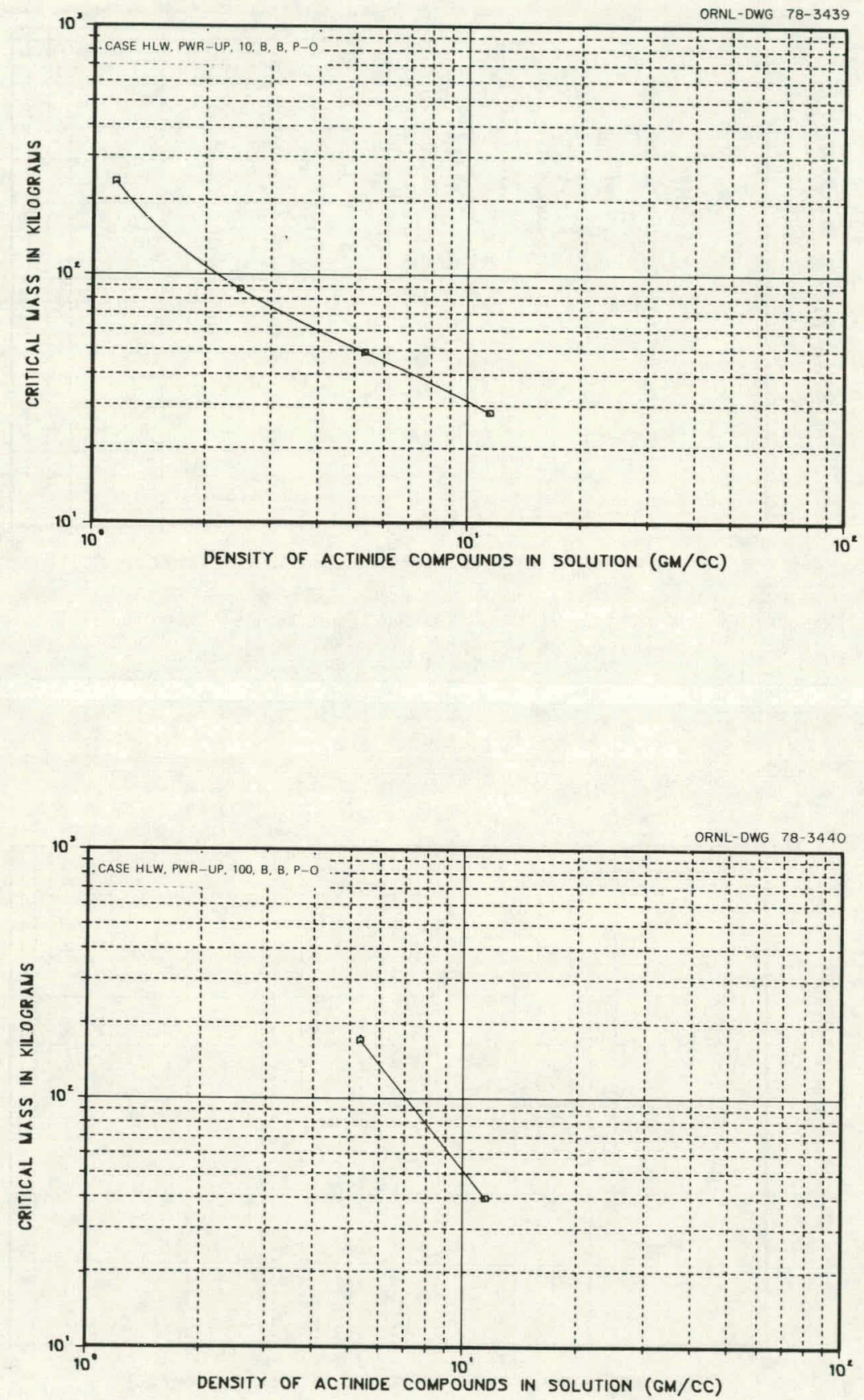

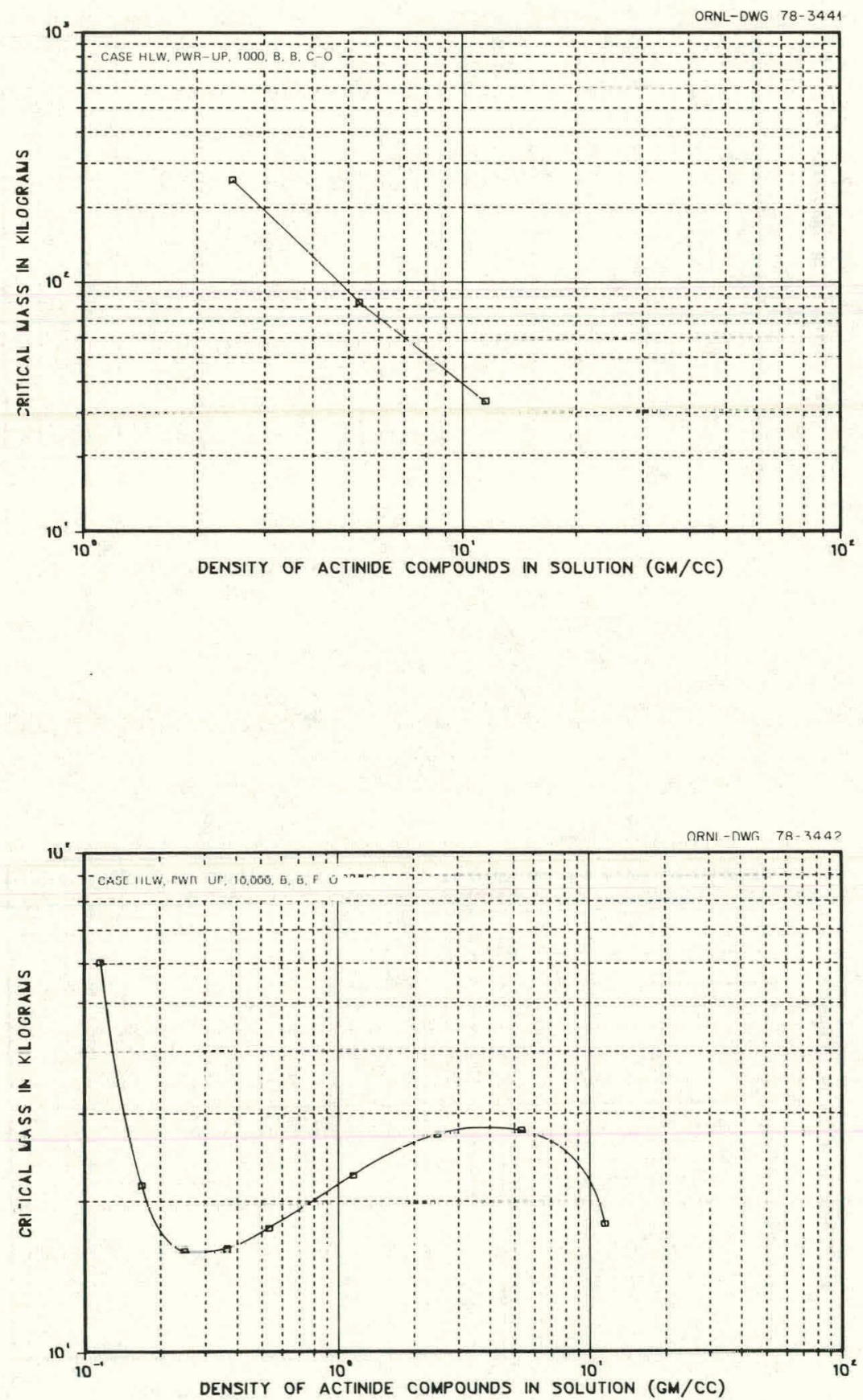

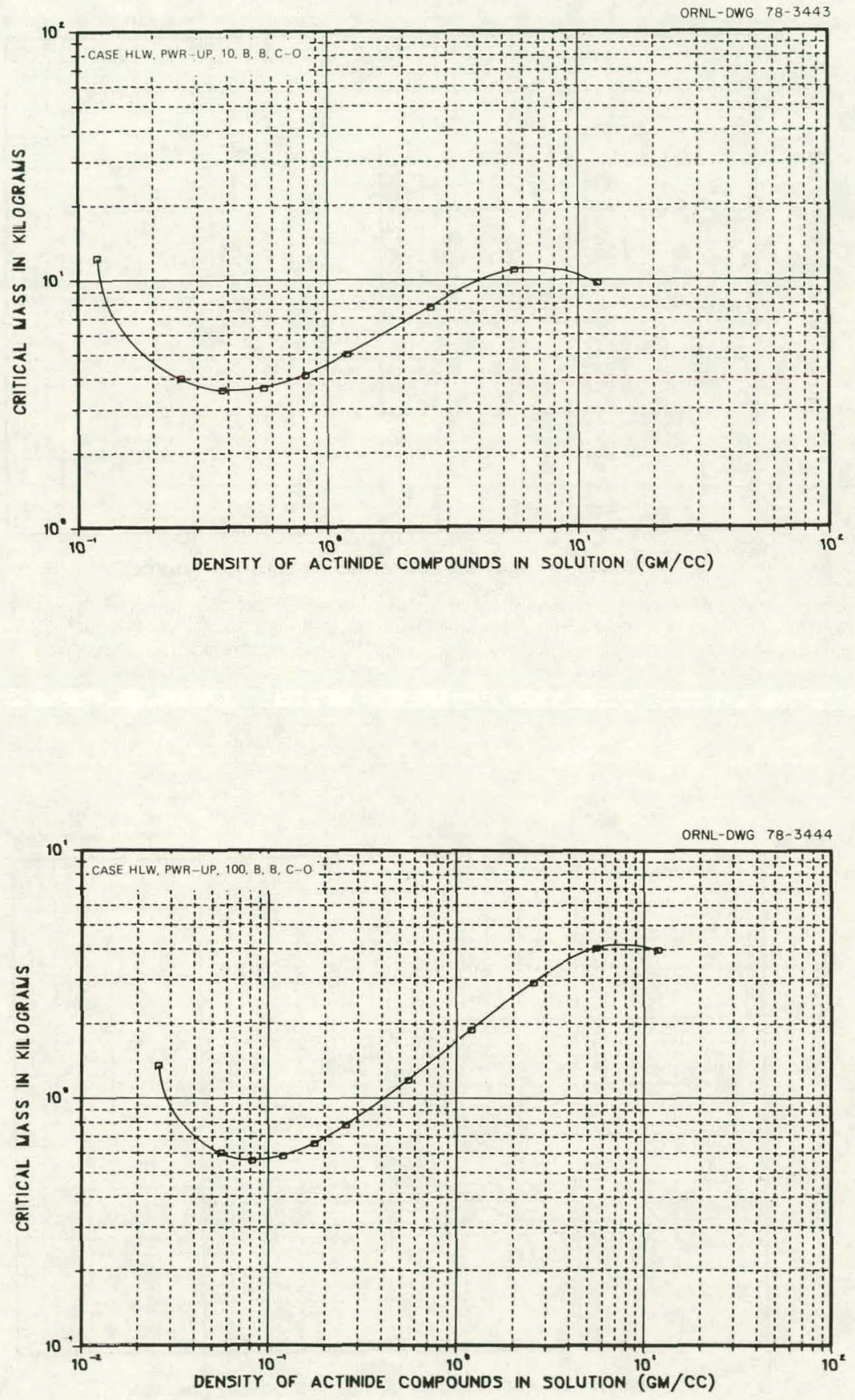

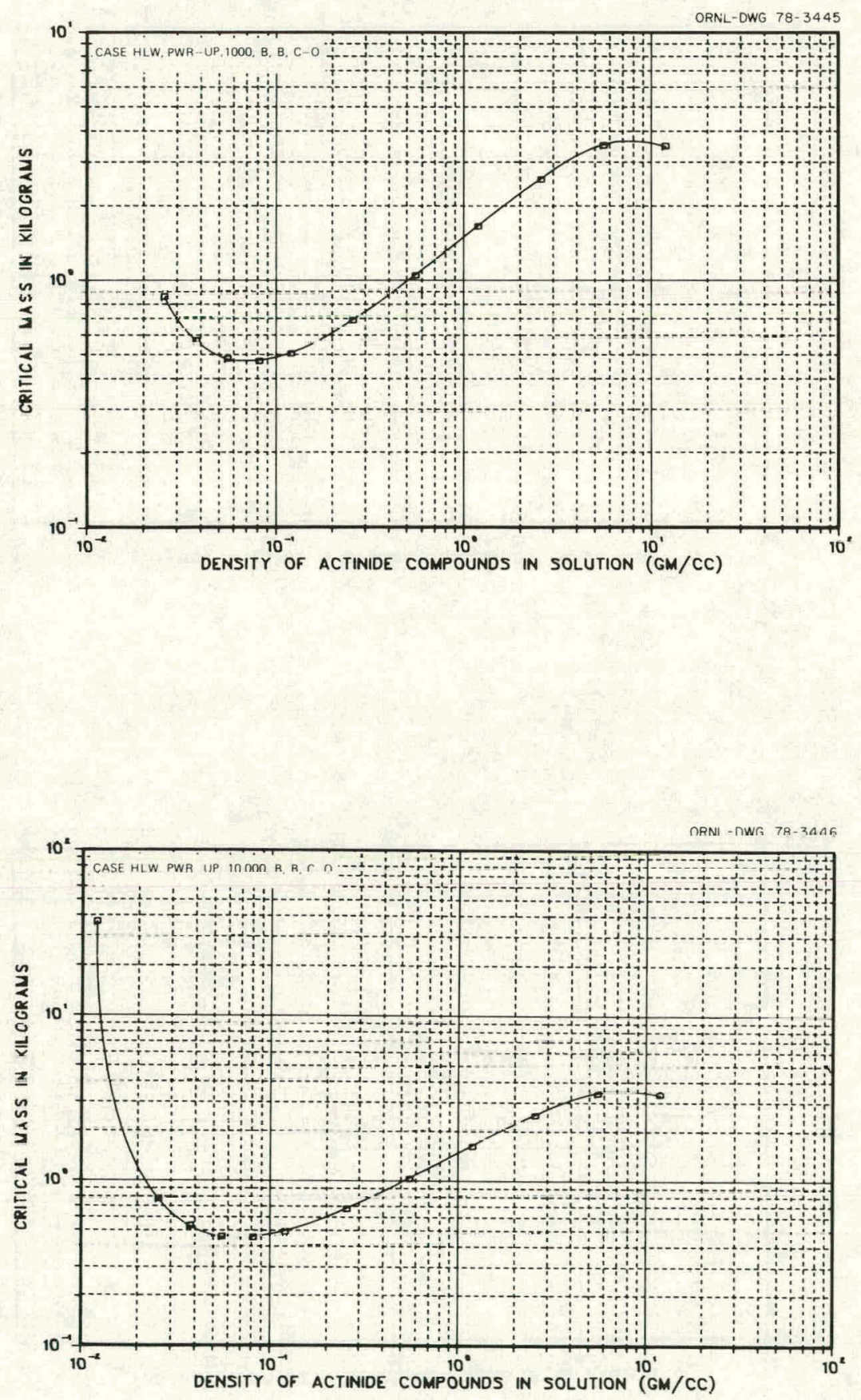


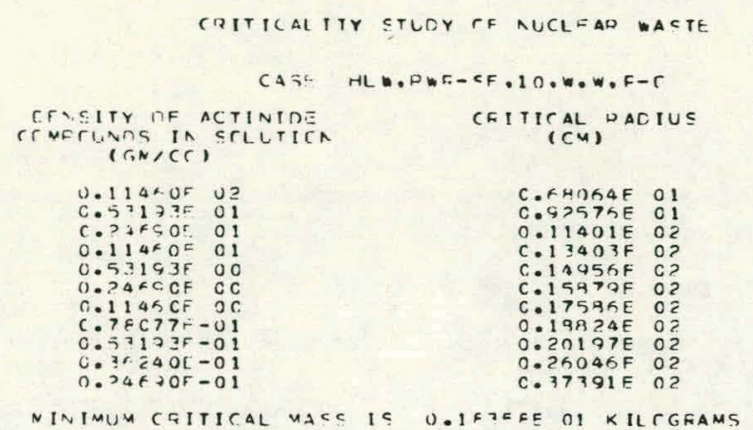

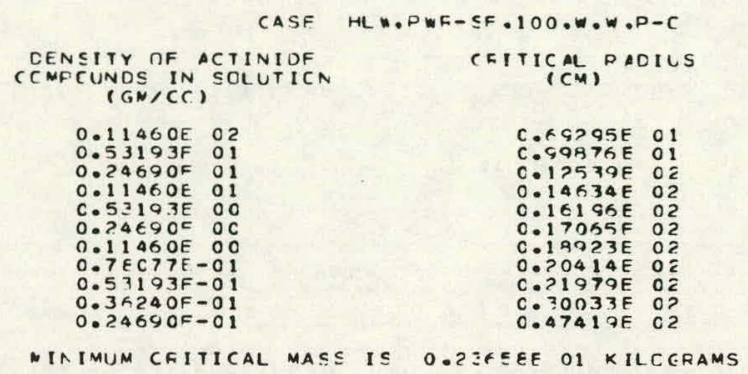

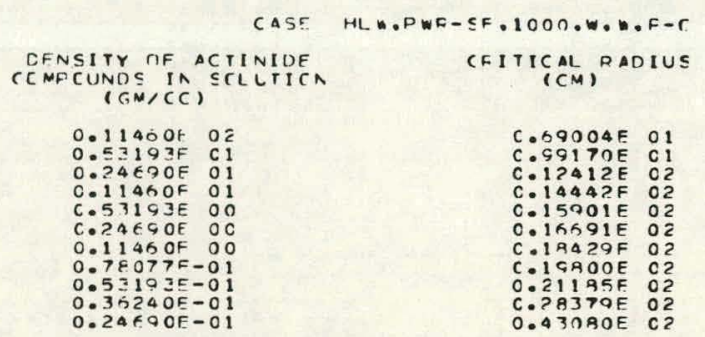

NINIMUN C.RITICAL MASS IS O.F11R7E OI KILCGFAMS
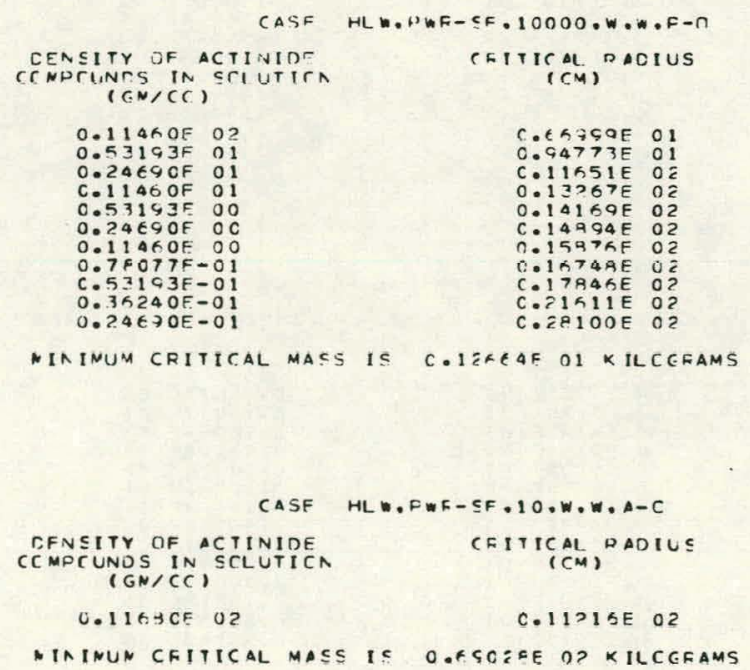

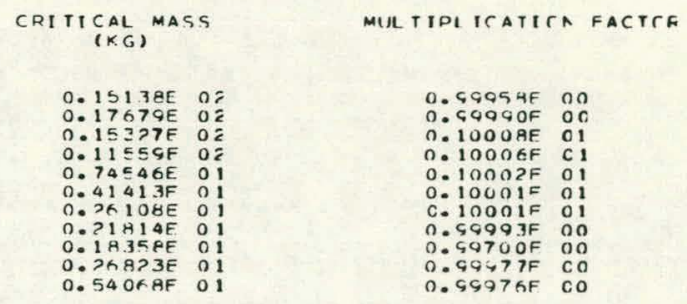

CRITICAL MASS
(KG)

$0.15974 F$ O

$0.23200 \mathrm{OF}$ Oद

$0.20391 \mathrm{E}$ O2

$0.946 \in E E$ OI

C. $27823 \mathrm{BE}$ O

. $41126 E$

$0.41126 E$ OI

MULTIPLICATICA FACTCF

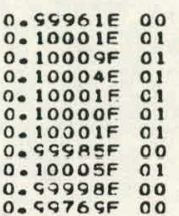

CRITICAL MASS

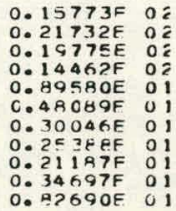

$0.99940 F$ OO
$0.99979 F$ OO
$0.1000 \mathrm{PF}$

O.100U AF CI

$0.10002 \mathrm{~F}$

$0.10000=01$

O. SY9 TE ON

0.09000 OF 00

O. SSARAF CO
MULTIPI ICATICA FACTCA
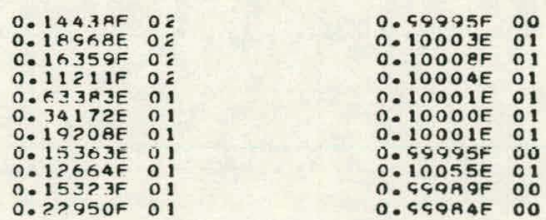

0. ?? $950 \mathrm{~F}$.

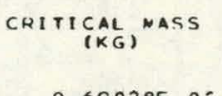

$0.6902 \mathrm{PE} \quad 02$
MULTIPLICATIOA FACTRR

$0.10000 \mathrm{~F} 01$ 


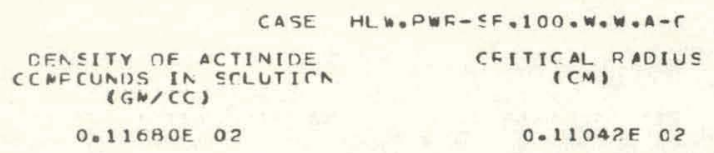

NININUN CFITICAL MASS IS O.FIEZZZF-OI KILCGFAMS
CRITICAL MASS

$0.65 E 67 F$ O =

CRITICAL NASS

$0.74384 E$ OE

CRI TI CAL MASS

(KG)

$0.15033 E \quad 03$
MULTIPLICATICA FACTCR

$0 . ९ ९ ९ ५ 8 \mathrm{~F} \mathrm{CO}$
MUL TIPI. ICATICA FACTIF

$0.59947 F$ on
CRITICAL MASS

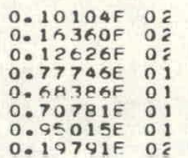

$0.95015 E$ OI

CHITICAL MASS

$0.48974 E$ O $0.412 .37 F$ O

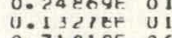
0.23720150 $0.18768 \mathrm{~F} \mathrm{OC}$ $0.13476 E$ OO $0.11002 F$
$0.17 \%$ OC 0.17 GAER OO CRI TICAL MASS

$0.25380 E$ O 1
$0.231 .36 F$
$0.1+1035$

$0.0>10 A F$ OC

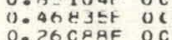

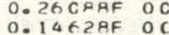

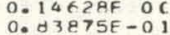

$0.83375 E-01$
$0.578175-01$
$0.57817 F F$

$0.51 \leq 23 \mathrm{~F}-01$

$0.52353 \mathrm{~F}-01$

$0.50 \$ 07 F-O$

$0.20910 \mathrm{~F}$ O 1
MULT TPL ICATICA FACTCF

C. SदR FIF OO

MILTIPLICATICA FACTCF

$0.10023 \mathrm{~F} \mathrm{C1}$

$0.99998 E$ On

$0.10125 E$ O1
$0.10004 F$ O1

O- COGAKE OO

O.10005F OI

0. COAGOE DO

MULTIPLICATICA FACTRE

$0.10003 E$ O 1

0.1001 F $O$

$0.10007 F$ O

11. innnyt Ut

$0.10002 E$ O 1

O. 1OGUAE OOI

$0.100 \mathrm{AF}$ ol

D. $10006 \mathrm{GE} 01$

0.5991 of
$0.55821 \mathrm{~F}$ 


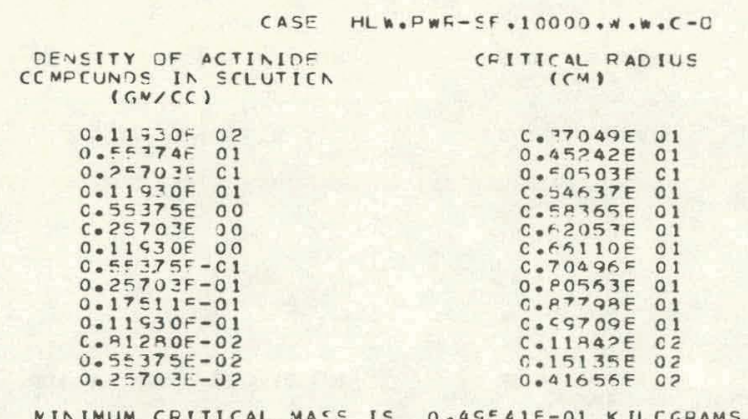

CASE HLW,PWR-UR, $10, W, W, P-0$

\begin{tabular}{|c|c|}
\hline $\begin{array}{l}\text { DENSITY OF ACTINIDE } \\
\text { COMPOUNOS IN SOLUTION } \\
\text { (GM/CC) }\end{array}$ & $\begin{array}{c}\text { CRI TI CAL RADIUS } \\
(C M)\end{array}$ \\
\hline 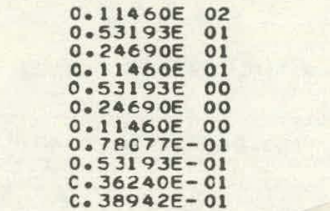 & 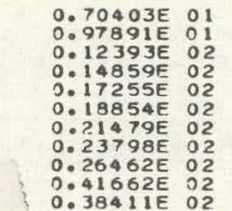 \\
\hline
\end{tabular}

MINIMUM CRITICAL MASS IS 0.4129IE OI KILOGRAMS
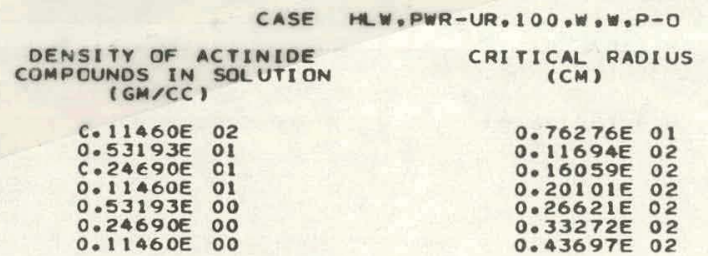

MINIMUM CRITICAL MASS IS $0.21304 E 02$ KILOGRAMS

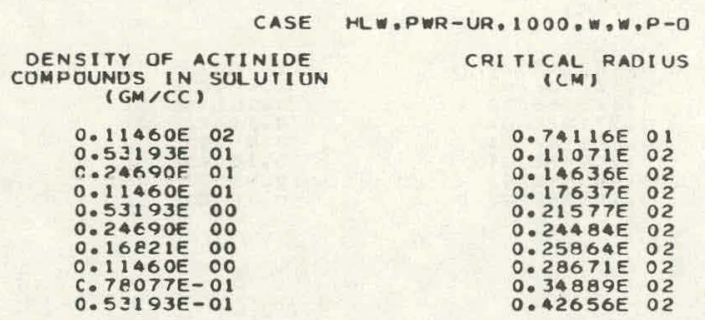

MINIMUM CRITICAL MASS IS $0.11314 E 02$ KILOGRAMS

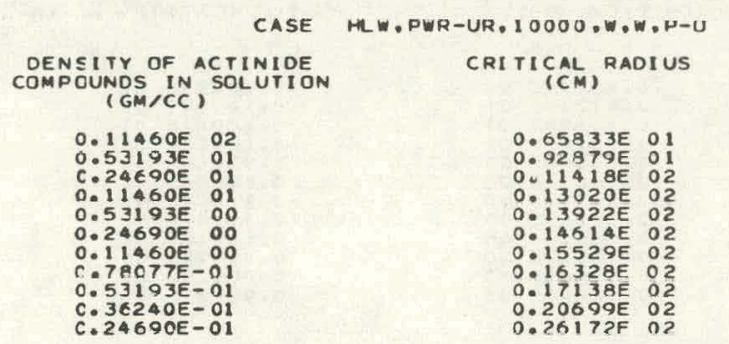

MINIMUM CRITICAL MASS IS 0.11217E O1 KILOGRAMS

\begin{tabular}{|c|c|}
\hline $\begin{array}{l}\text { CASE } \\
\text { DENSITY OF ACTINIOE } \\
\text { COMPOUNDS IN SOLUTION } \\
\text { (GM/CC) }\end{array}$ & $\begin{array}{l}M L, P W R-U R, I 0000 \cdot W \cdot W \cdot H-U \\
\text { CRITICCAL RADIUS }\end{array}$ \\
\hline 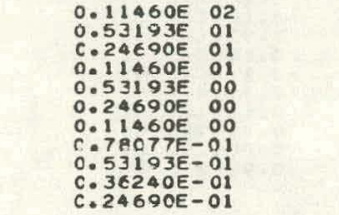 & 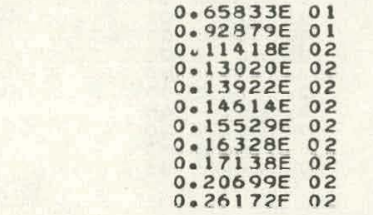 \\
\hline
\end{tabular}

CRITICAL MASS

0. TS4ISF 01

$0.13 \varepsilon G E F$ O 1

$0.81511 E$ OC

$0.46120 E$ OC

$0.25726 \mathrm{~F} 00$

$4.1340 E$ OC

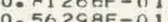

$0.49 E \triangle A F=01$

$0.49541 \mathrm{~F}-01$

$0.56545 \mathrm{~F}-01$

$0.80427 E-01$
$0.77824 E-O C$

CRITICAL, MASS

$0.16752 E 02$

.20902 OS

0.196A7E 02

$0.11448 F$ F

$0.69322 E$ OI

$0.47574 E$ OI

$0.44079 E$ OI

$0.41291 E$ OI

$0.10978 E$ O2

CRITICAL MASS

$0.21304 E_{02}$

$0.35634 E \quad 02$

0.42835 E 02

$0.42039 \mathrm{E} 02$

$0.38094 E$ O2

CRITICAL MASS

U. $19545 E$ O2

J. $30237 \mathrm{E}$ O2

$0.32423 E$ O2

$0.26336 E$ O2

$0.15180 E$ O2

$0.12191 \mathrm{E}$ O?

$0.11314 E$ O2

O.1389OE O? 


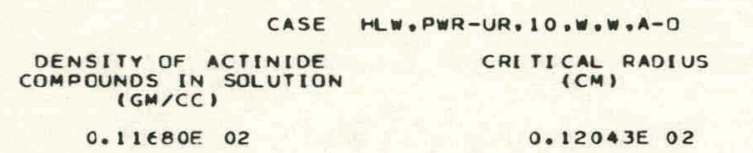

MINIMUM CRITICAL MASS IS $0.85460 E$ O2 KILOGRAMS

$$
\begin{aligned}
& \text { CRITICAL MASS } \\
& \text { (KG) } \\
& 0.85460 E 02
\end{aligned}
$$

CRITICAL MASS

$0.88385 E 02$

$0.12179 E \quad 02$

CASE HLW.PWR-UR,100,W.W०A-O

DENSITY OF ACTINIDE
COMPOUNOS IN SOLUTION

0.11680 E 02

MINIMUM CRITICAL MAES IS $0.88385 E$ O2 KILOGRAMS

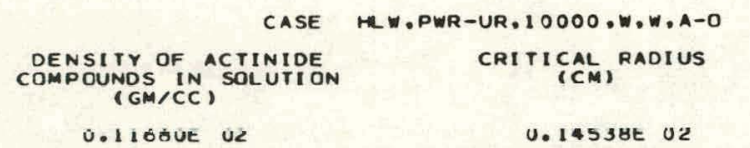

MINIMUM CRITICAL MASS IS 0.15034 OS KILOGRAMS

DENSITY OF ACTINIDE
COMPOUNDS IN SOLUTION
(GM/CC)
C.11680E O2
MINIMUM CRITICAL MASS IS

MINIMUM CRITICAL MASS IS 0.11991E 03 KILOGRAMS

\author{
CRITICAL, MASS \\ $0.11991 E 0_{3}$ \\ MULTIPL ICATION FACTCR \\ $0.99640 E 00$
}

CRIT ICAL MASS

$0.15034 E \quad 03$

$0.99170 E \quad 00$

MULTIPLICATION FACTOR
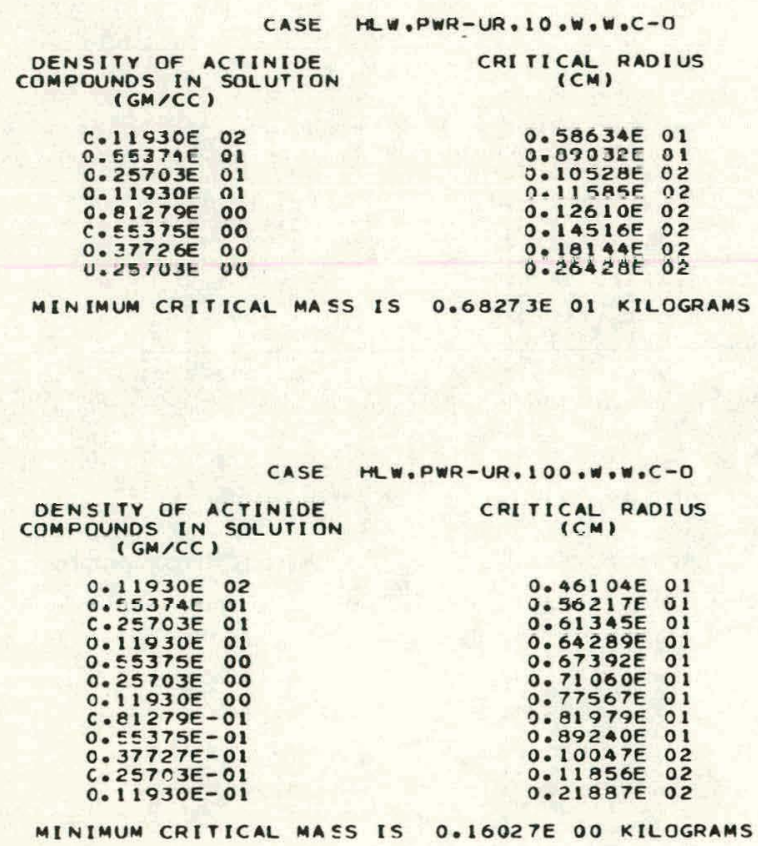

CRITICAL MASS

$0.10074 E 02$

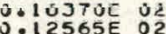
0.77700 OI $0.68273 F$ ol $0.7094 \mathrm{BE}$ OI $0: 94398 E$
$0.19875 F$

MINIMUM CRITICAL MASS IS $0.68273 E$ OI KILOGRAMS

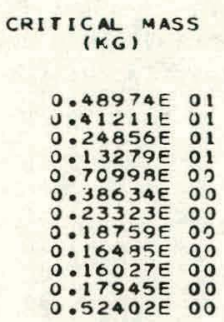

MULTIPL ICATION FACTCR

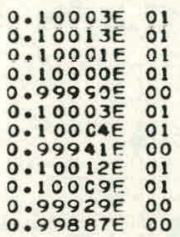

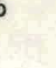



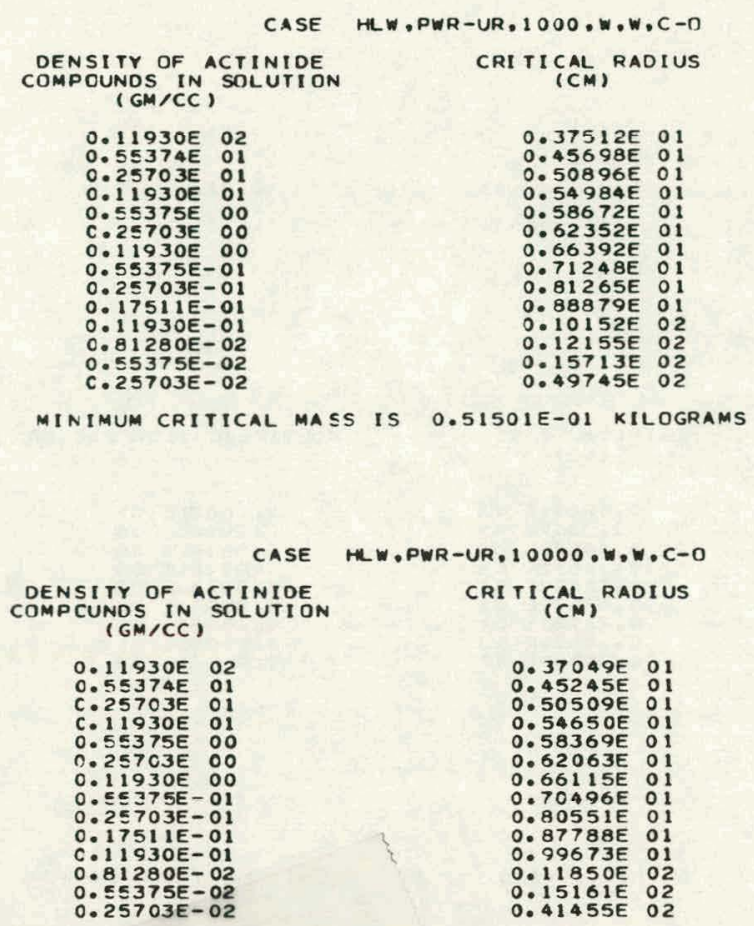

MIA IMUM CRITICAL MASS IS O.49487E-01 KILOGRAMS

\begin{tabular}{|c|c|}
\hline CASE & $H L W, P W R-U R, 10, W \cdot W \cdot U N P A C-0$ \\
\hline $\begin{array}{c}\text { DENSITY OF ACTINIDE } \\
\text { COMPOUNDS IN SOLUTION } \\
\text { (GM,CC) }\end{array}$ & $\begin{array}{c}\text { CRITICAL RADIUS } \\
(C M)\end{array}$ \\
\hline C.115COE C2 & $0.43375 E \quad 02$ \\
\hline
\end{tabular}

\begin{tabular}{|c|c|}
\hline $\begin{array}{l}\text { DENSITY OF ACTINIDE } \\
\text { COMPOUNOS IN, SOLUTION } \\
\text { ( GM /SC, }\end{array}$ & CRI TI ${ }_{(C A M)}^{C A L}$ RADIUS \\
\hline $0.11500 E \quad 02$ & $0.44538 E \quad 02$ \\
\hline
\end{tabular}

CASE HLW.PWR-UR,1000,W,W.UNPAC-O DENSITY OF ACTINIDE
COMPOUNDS IN SOLUTION CRITICAL RADIUS
(GM/CC) $0.11500 E \quad 02$

$0.44492 E 02$ MIMIMUM CRITICAL MASS IS R.APAPTF O4 KILOGRAMS
CRITICAL, MASS

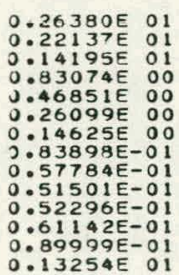

CRITICAL MASS

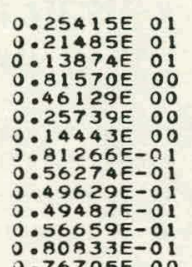

$0.76705 \mathrm{E}$.

CRIT ICAL MASS

J.39312E 04

CRITICAL MASS

$0.42561 E$ O4

CRITICAL MASS

$0.42427 E 04$
MUL TIPL ICATION FACTCR

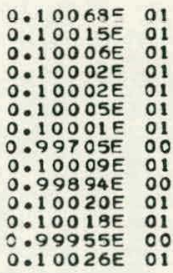

MULTIPL ICATION FACTCR

$0.100800^{0}$

$0.10020 E$ O

$0.10001 E$ OI

$0.10002 E$ O

0.10003 E

D.10035E O

$0.10011 E$ OI

$0.99915 E$ OO

$0.10015 E$ O

O.10O1JE OI

$0.99689 E^{00}$

MULTIPLICATION FACTOR

$0.10000 E^{01}$

MULTIPL ICATION FACTCR

0.10000 OI

MULTIPLICATION FACTCR

$0.10000 E 01$

MULIIPLICATION FACTCR

J.1 ŨÕÕE OI
$0.11500 E$ O2

$0.41287 E 02$

MINIMUM CRITICAL MASS IS $0.33905 E$ OA KILOGRAMS 


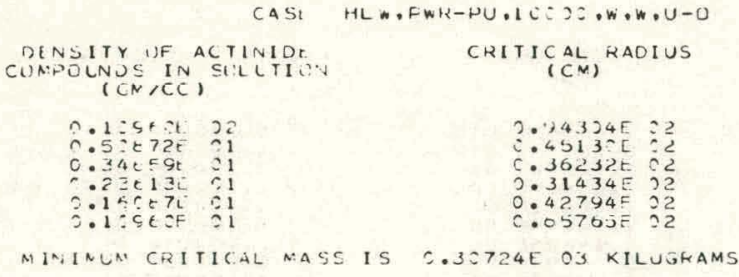

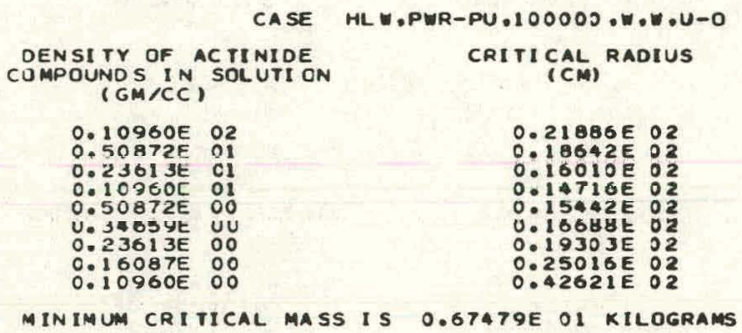

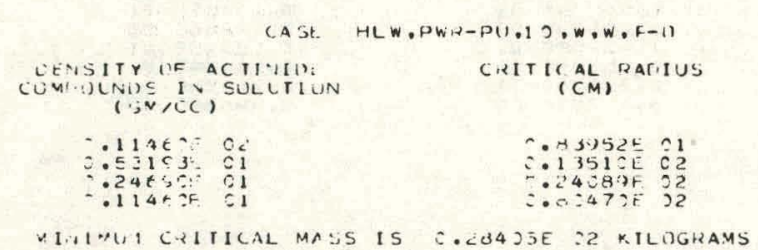

\begin{tabular}{|c|c|}
\hline CASE. & $H L W, P W R-P U, 100, W \cdot W \cdot P-O$ \\
\hline $\begin{array}{l}\text { OENSITY OF ACTINIDE } \\
\text { COMROUPIOE IN, SOLLTICA } \\
\text { (GN, CC ) }\end{array}$ & 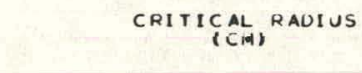 \\
\hline $\begin{array}{l}0114 E S E \text { O? } \\
0.53193 F \text { O1 }\end{array}$ & $\begin{array}{l}c .95233 \mathrm{c} \\
c .25216 \mathrm{E} \\
\mathrm{C}\end{array}$ \\
\hline
\end{tabular}

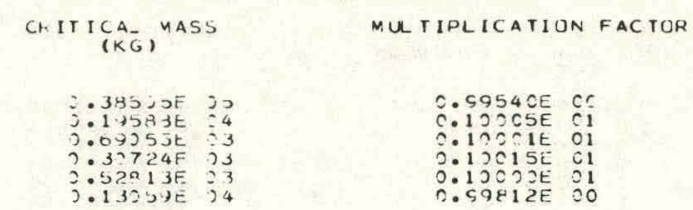

CRITICAL MASS

MULTIPLICATION FACTOR
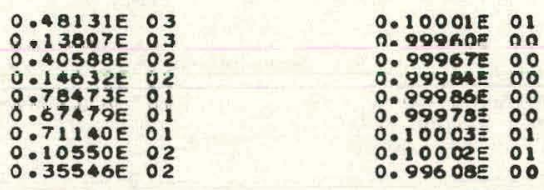

CHITICA (KG) $^{\text {MASS }}$

$3.23405 t^{2} 32$ $3.54344 E$ E

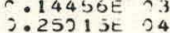

CRITICA-, MASS

$0.41463 E_{0} \quad 02$

MUTIPLICATION FACTOR

$0.10015 E$ OI

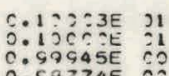

CHITICAL MASS

$3.32012 \mathrm{E} 22$

3.373
$0.3250 E$

MI.I MUIN CKITICAL MASS IS O.J2012E DL KILIJGRAMS

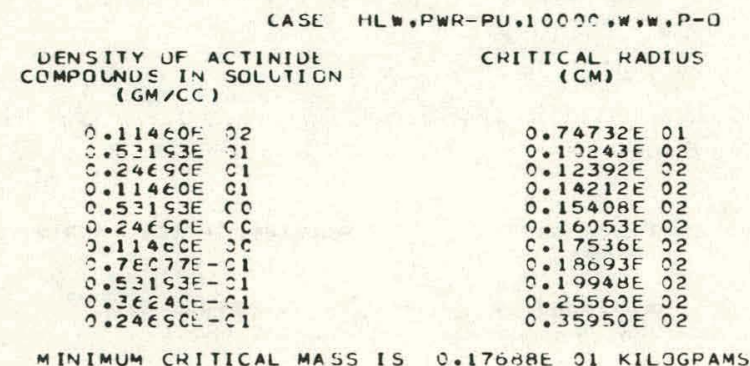

CHIT ICAL MASS

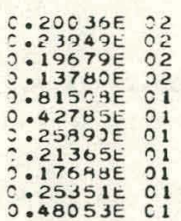

MU TIPLICATION FACTOR

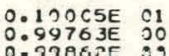

MUL TIPLICATION FAC TOR

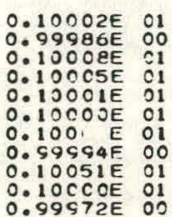



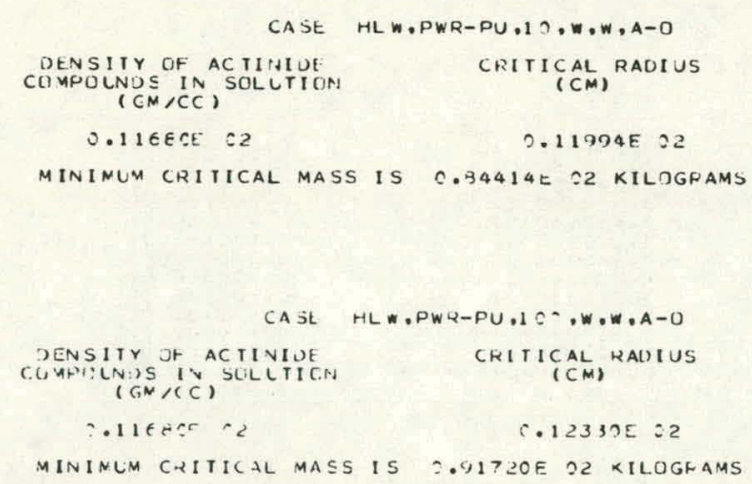
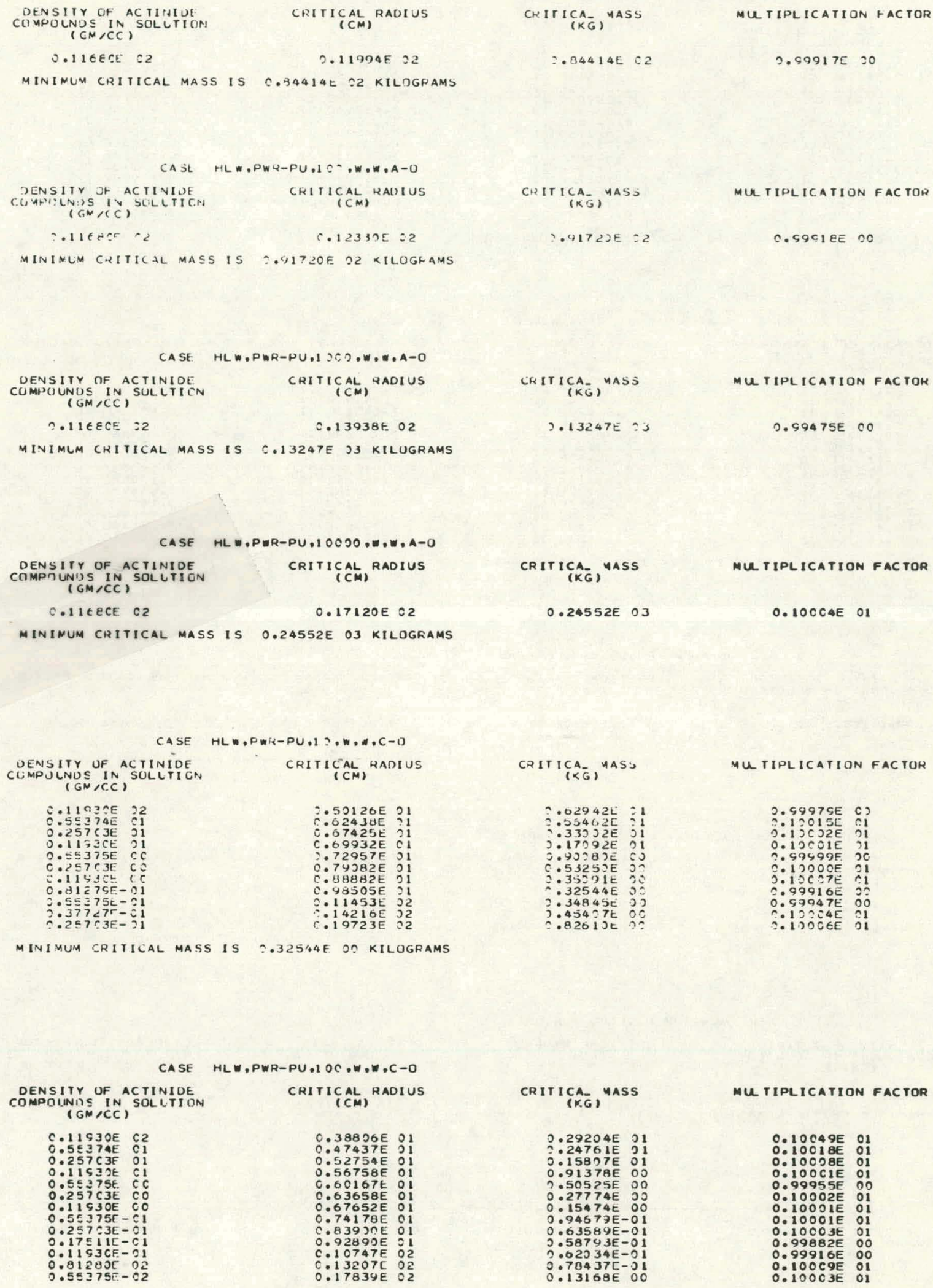

MINIMUM CRITICAL MASE IS 0.58793E-OI KILOGRAMS
MUL TIPLICATION FACTOR

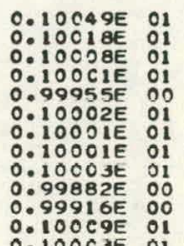

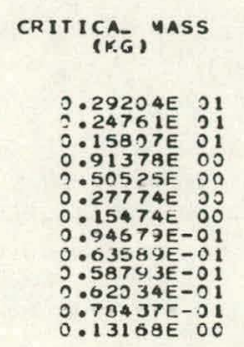




\begin{tabular}{|c|c|}
\hline $\begin{array}{l}\text { DENSITY LF ACTINIDE } \\
\text { COMPIJUNOS IN SOLUTION } \\
\text { (GN,CC) }\end{array}$ & $\underset{\text { CRITICAL, RADIUS }}{\text { (CM) }}$ \\
\hline 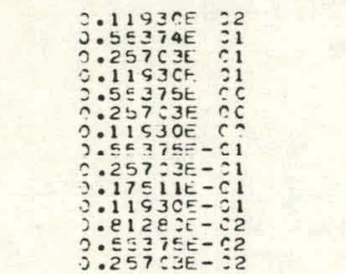 & 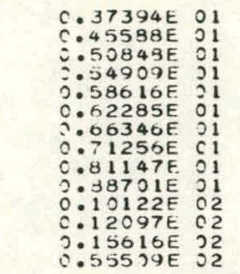 \\
\hline
\end{tabular}

\begin{tabular}{|c|c|}
\hline $1 \mathrm{ASE}$ & ה \\
\hline 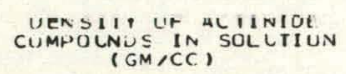 & $\begin{array}{c}\text { CRITICAL RALIUS } \\
\text { (CM) }\end{array}$ \\
\hline 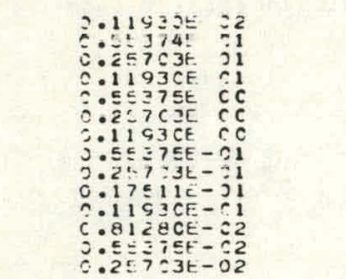 & 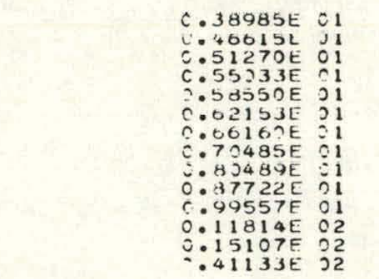 \\
\hline
\end{tabular}

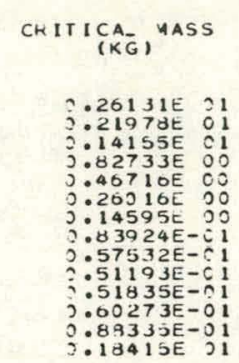

CIITICA (KG) $^{\text {MASS }}$

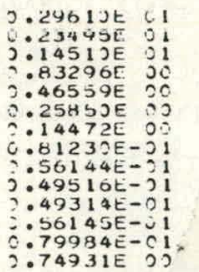

MINIMUM CRITICAL MASS IS $0.49314 t-31$ KILOGRAMS

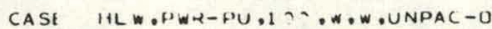
DENSITY UIF ACIINIDE
SIMPJUNIIS IN SULLTION CRITICAL RADIUS

CASE HLW,PWH-FU,1 $300, W, W, U N A A C-U$

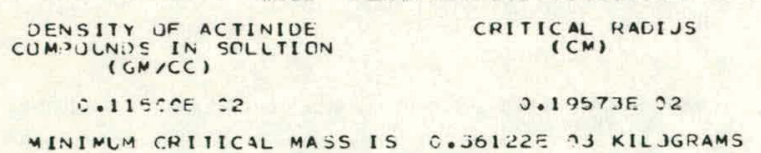

CASE HLW, PWR-PU, $)=x$, , W W UNPAC-0

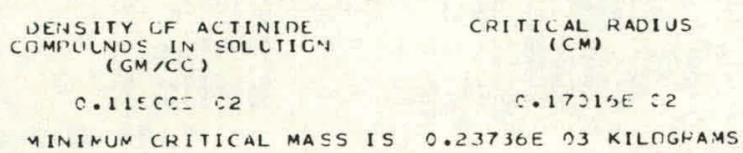

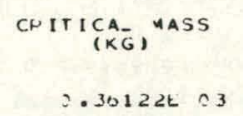

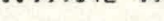

$0.13063 E$ 21 $0.12010 E$ OI 0.99986 E C.13JC 3E C1 $\begin{array}{ll}0.10034 E & C 1 \\ 0.10 C 12 E & O 1\end{array}$ C:99910E CC $0.100242 E$ O1 C. $99576 \mathrm{E}$ OO
$\mathrm{C} .98 \mathrm{SC} \mathrm{BE}$ OC

MU TIMLICATION FACTOR

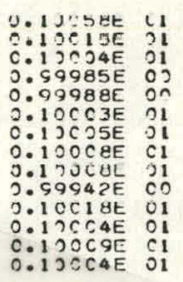




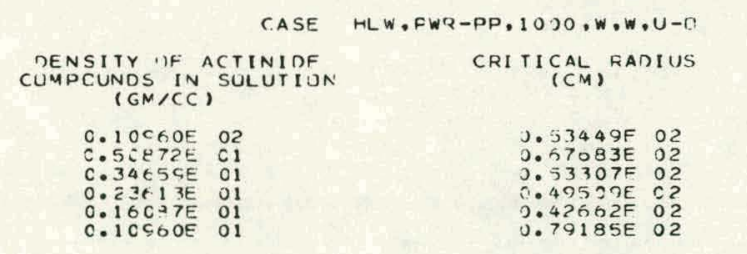

MINIMLM CHITICAL. MASS IS 0.52327 O3 KILOGPAMS

$$
\begin{aligned}
& \text { CHITICAL MASS }
\end{aligned}
$$

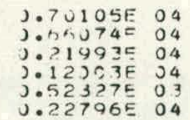

CRITICAL, MASS

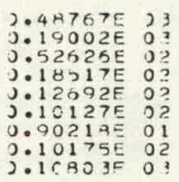

MIVIMUM CRITICAL MASS IS 0.9021 BE O1 KILOGHAMS

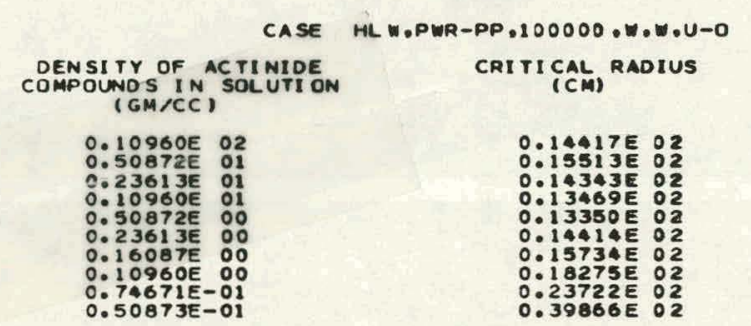

MINIMUM CRITICAL MASS IS 0.26246E OI KILOGRAMS

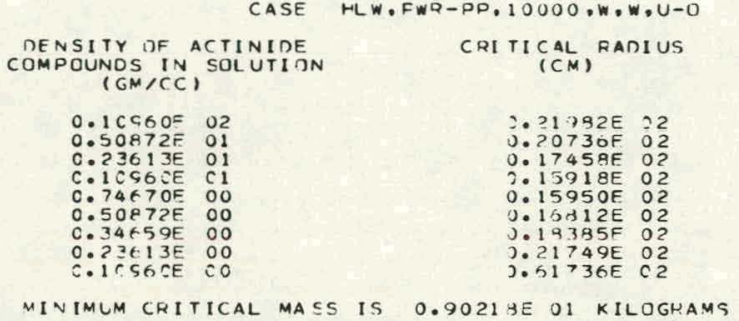
DENSITY UF ACTINIDE
COMPCUNTS IN SOLUTION
(GM,CC)
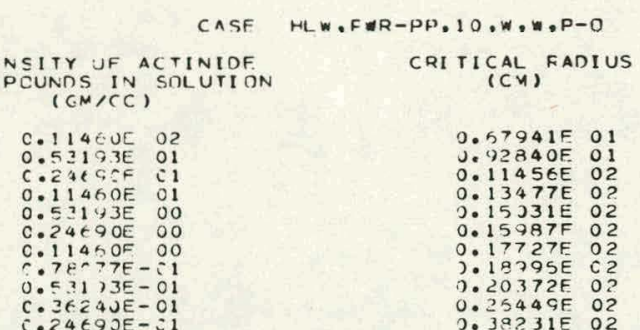

CRI TICAL, FADIUS

$0.57941 E 01$

$0.92840 E$ OI

0.13477 E 02

O.15 $1531 \mathrm{E}$ O2

$0.15987 F$ O

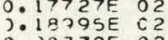

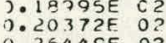

$0.25449 \mathrm{GE}$ O2

MINIMUM CRITICAL MASS IS O.18839E OI KILOGRAMS

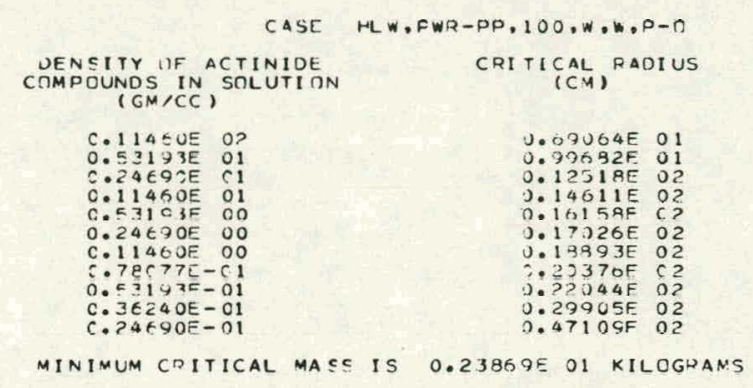

CRITICM ${ }_{(K G)}^{\text {MASS }}$

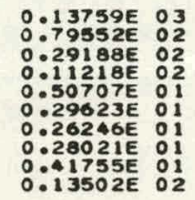

$0.13502 E \quad 02$ $\begin{array}{ll}0.799565 & 00 \\ 0.100095 & 01\end{array}$

$3: 10055 \mathrm{C}$ c

0.9

: $100 C E E$ C1

$0.39925 E$ CO

$0.99955 E$ वO

$0.1000 J E$ O

$0.299 \varepsilon 5 E$
$3.72523 E$

MULTIPLICATION FACTOR

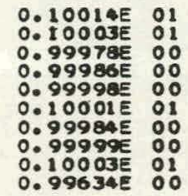

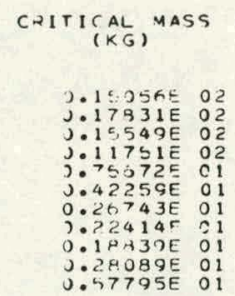

MULTIDLICATIITA FACTCH

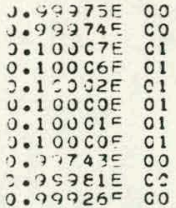
CRITICAL ${ }_{(K G)}^{\text {MASS }}$

MULTIPLICATIOA FACITR

J.15315E O? . $22071 \mathrm{E} 02$ 3.149736 02 $303907 E$ ग1 $0.51044 \mathrm{E}$ O1 $0.32374 \mathrm{E}$ O1 $?: 37570$ OI ,:23769E 01 ?.40599E 01
$0.10313 E$ O2

J.393795 00 J.1 U J C2E C1 J. $100 \mathrm{CAF}$ CI O. ICJC1E CI $0.100 \mathrm{COE} \mathrm{CI}$ 0. $10 J 415$ C1 10OCSF 01 J. 1OSC1E CI 


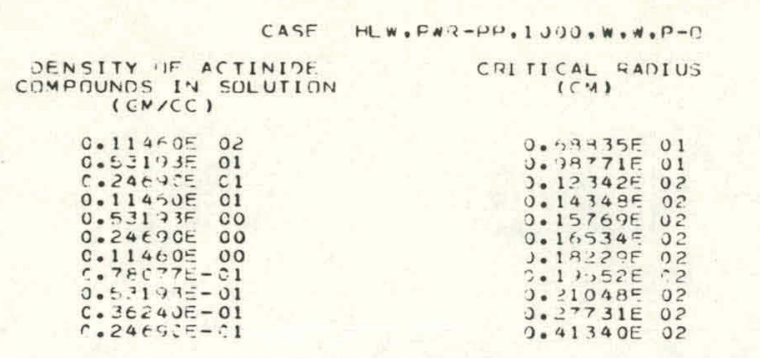

MINIMUM CRITICAL MASS IS 0.207775 OI KILOGPAMS

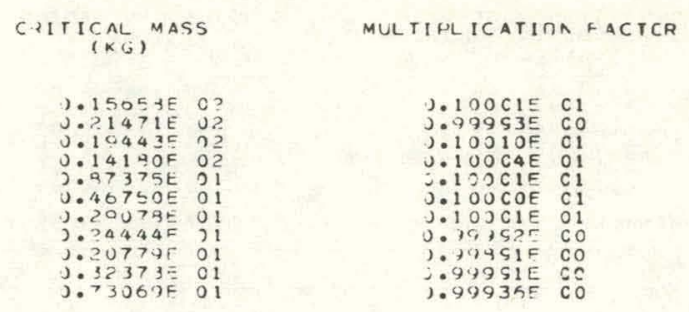

CRITICAL MASS

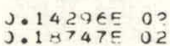

Jilu174E OD

Jilugat u

362501 E

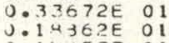

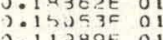

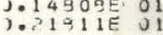

$.100 \mathrm{C} 1 E$

).10010F C

joOcie

$.100 \mathrm{CIE}$

南

ग.99935E CO

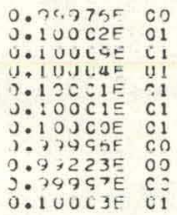

0.73735569

u.iuUcae

9:10,164 पy

JiOJCOE

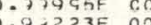

$0.100 \mathrm{CB}$ Ci

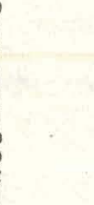

MINIMUM CRITICAL MASS IS O.119ATE OI KILOGRAMS

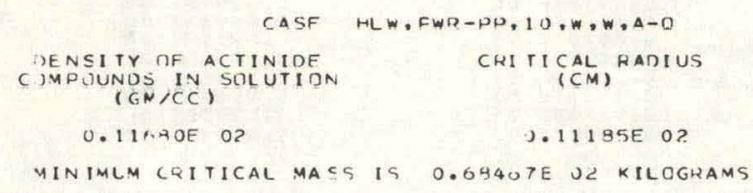

MINIMLM CRITICAL MASS IS $0.69407 E$ UL KILOGRAMS

\section{CRITICAL MAS'}

X., $\$ 4457 E$ U?
CRITICAL MASS
$2,4=01522$

CASF HLW,FW2-PP,100,W,W,A-0 DENSITY IF ACTINIDE
CUMPOUNDS IV SOLUTION
(CN,CE)

n $11+\sin =0$

3. 11,027F 0?

MINIMUM CRITICAL MASS IS $0.65601 E$ OL KILCGPAMS 

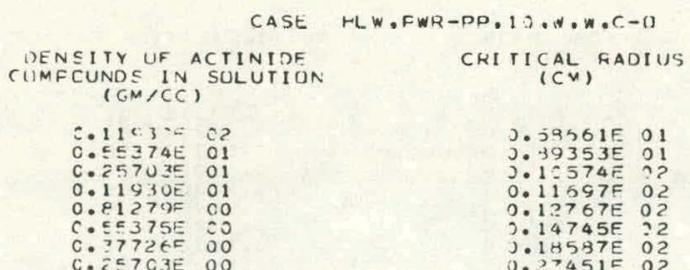

$0.5361 \mathrm{E} 01$

ग. $39353 \mathrm{E}$ O 1

$3.11574 \mathrm{E}$ ?
$0.11597 \mathrm{~F}$ ? $11597 F$ O2
$0.12767 E$ O2 $14745 E$
$18587 E$ MINIMLM CHITICAL MASS IS 0.708OIE JI KILCGRAMS
CASF HLW.FWR-PP.1UU,NOW.C-C

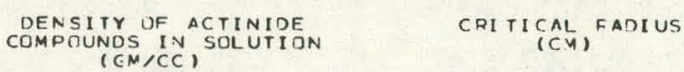

c. $11930 E$ O2 0.553745 01 C. $25703 E$ : 11 $11930 E$
0.1
$05375 E$ OO $\begin{array}{ll}0.05 \\ 0.5303 \mathrm{E} & 00\end{array}$ $0.11930 \mathrm{OF}$ 00 $0.0 \leq 375 E-01$ C. $37727 \mathrm{E}-01$ $\mathrm{C} .11930 \mathrm{E}-01$

MINIMUM CRITICAL MASS IS 0.16263 J DO KILOGRAMS

$0.45203 F \quad 01$

. 53360 O1

$64375 E$ O $67490 E$ O 077788 O 28222 JE CI $.11947 F$ O2
CHITICAL MASS

J.1OJRSE O? JU 1038 B O J.1 $373=E$ O? $3.79995 F$ OI $3.70951 \mathrm{~F}$ O ). $10149 \mathrm{9E}$ D2
MULTISI ICATIOA -ACICR

J.1 गOCEF C1 J.1 0069e OI O. 1 OOCJF O j.1 Juc7e c1
CHITICAL MASS

$0.49299 E 01$ J.41495E OI $0.24979 F$ OI $9.13372 \mathrm{E}$ O1 $38343 E$ OO $0.23471 E$ OO $.18324 E$ ? $116263 \mathrm{O}$ O J.18361E O.J 


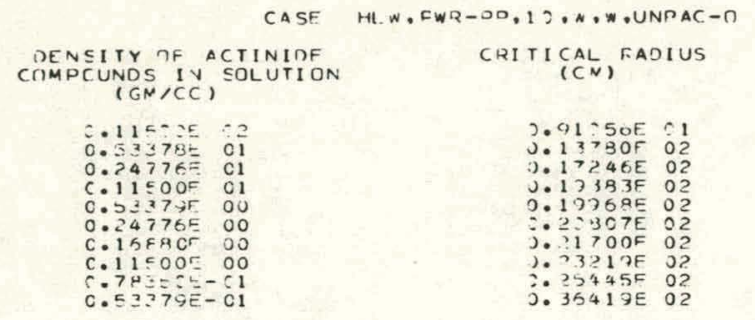

MINIMLN CFITICAL MASS TS $0.540 ? 1$ OI KILOGRANS

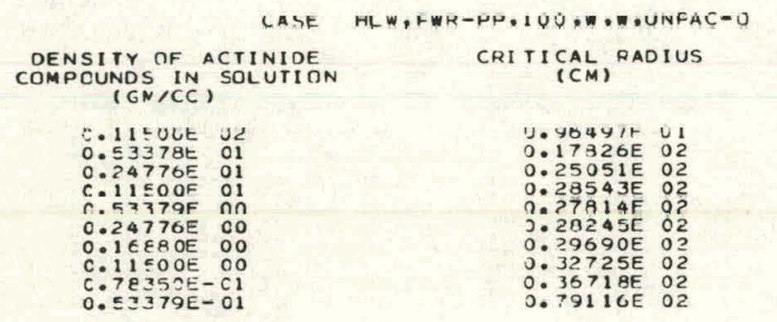

MINIMUM CPITICAL MASS IS $0.16247 E$ O2 KILOGRAMS
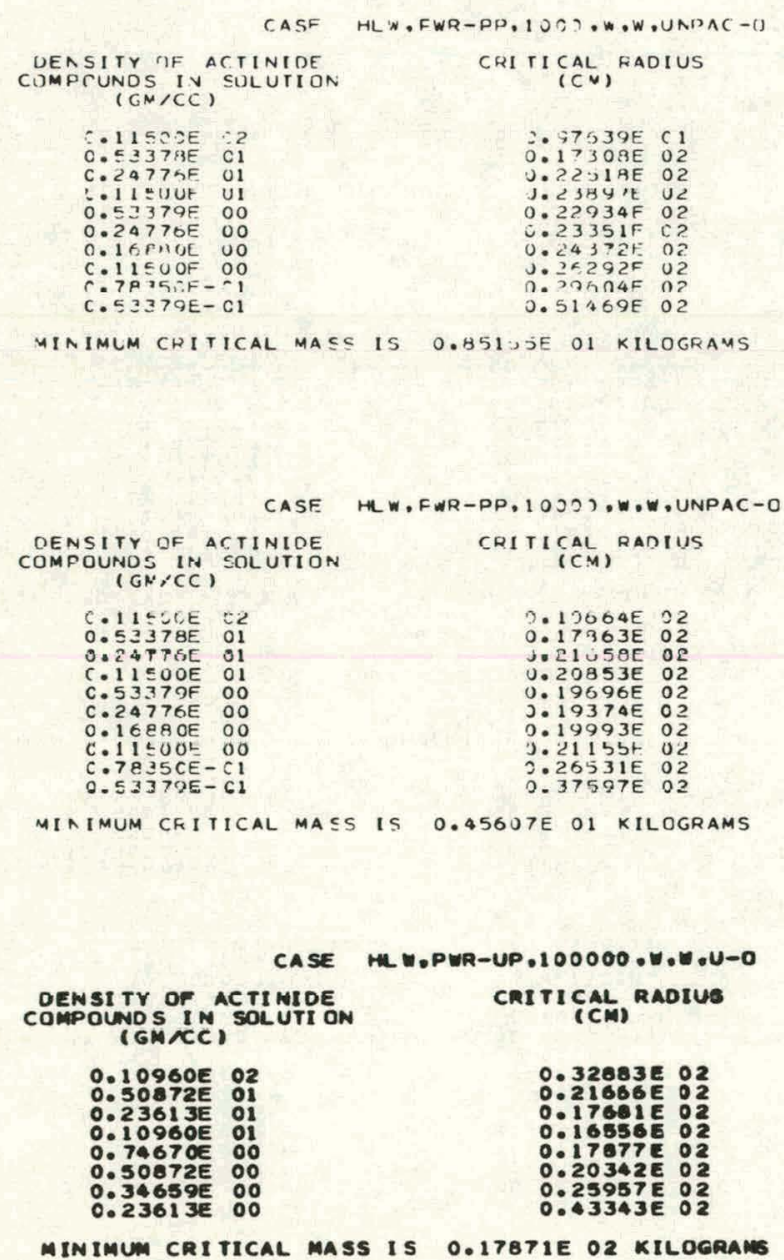

MINIMUM CFITICAL MASS IS $0.45607 E$ O1 KILOGRAMS
$3.10 J 1 \in F \quad 01$

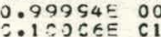
010 . 0.10000 C $3: 097 \mathrm{SQE}$ 00 J. $39797 F$ CO J. 1 OJ COE 01 $0.100 E A E$ O 1
J. 999 SOE OO

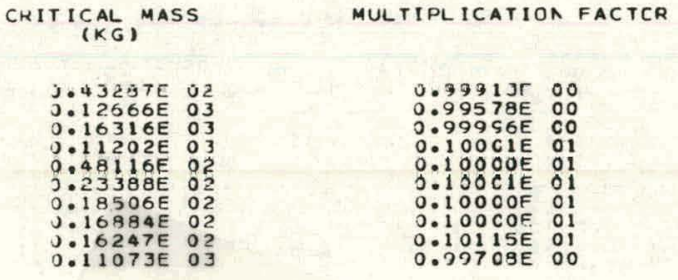

CRITICAL MASS

043425
0110935 03

11 BS1E OS

,.65144t U

$30.971 \mathrm{E}$ O2

, 102170 02

$\begin{array}{rl}0.102375 & 02 \\ 0.47596 & 01\end{array}$

0.30447502

CRITICAL MASS

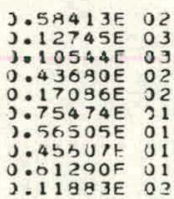

$0.01290 \%$ OI

MUL TIPL ICATIOA FACTER

บ. $79731 F 00$

3.39739500

,.997EGE CO

J.1 vucut

0.9?

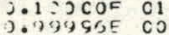

0.10067 C1

$J .399 C 4 E$ CO

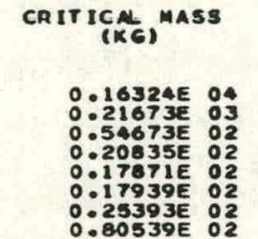

MULTIPLICATION FACTOA

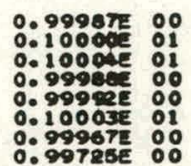



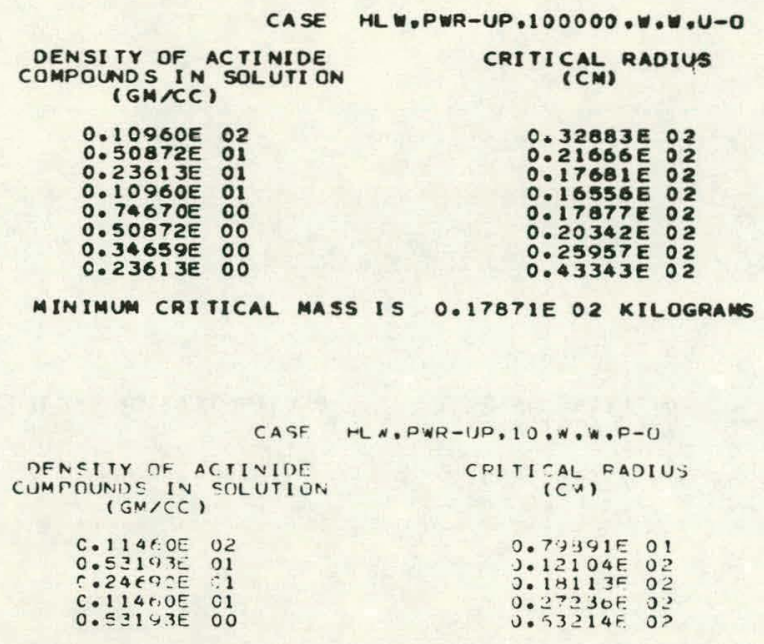

MINIMUM CKITICAI. MASS IS 0.24473 O O2 KILOG'AMS

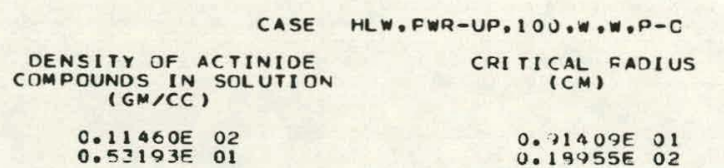

MINIMUM CRITICAL MASS IS $0.36666 E$ O2 KILOGRAMS

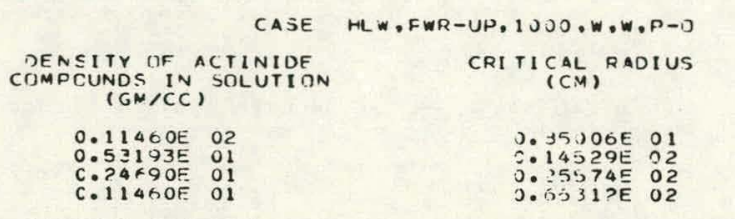

MINIMUM CRITICAL MASS IS 0.294MTE OL KILOGRAMS
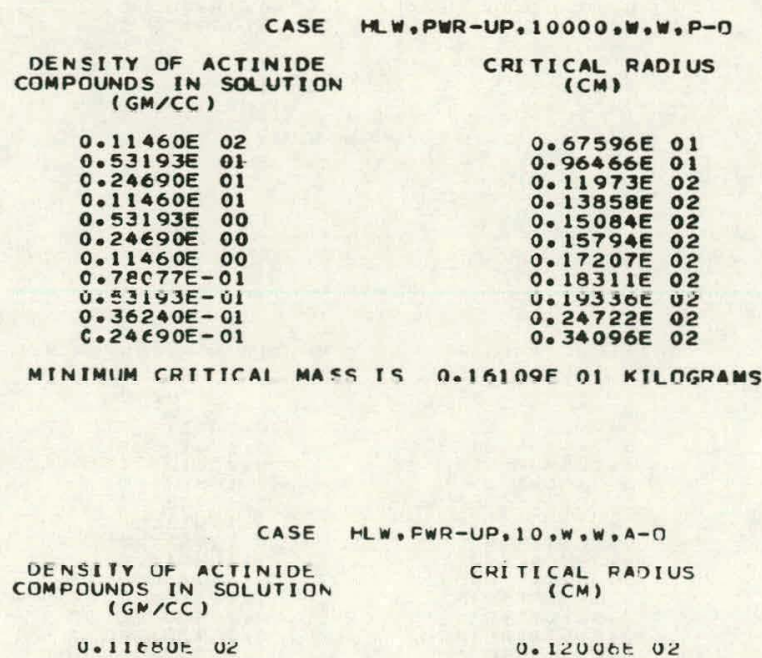

MINIMUM CRITICAL MASS IS $0.84692 E 02$ KILCGRAMS

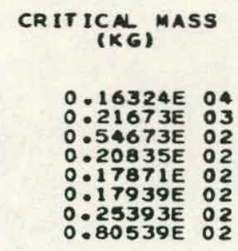

MULTIPLICATION FACTOR

CPITICAL MASS

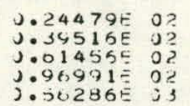

CRITICAL MASS

U. 366E5E 02

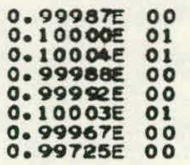

MULTIPLICATIUAN TACTCR

ग. उदूव

3.1 JUCOE C1

j.99959F 00
CRITICAL MASS
$\begin{array}{rl}J .294975 & 02 \\ \text { J.08332E } & 02\end{array}$
U. $17299 E$ OJ

3.0.30750 $C$

0.99959E CO

3.100145 C1
$0.99167 E$ OO

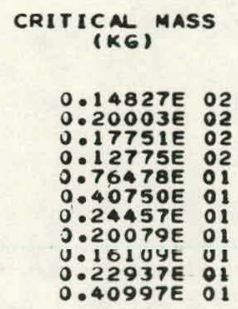

MULTIPL ICATION FACTCR

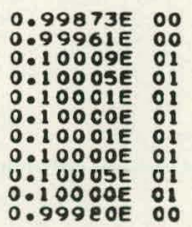

CKITICAL MASS

J.84642E 02

MULTIPLICATIOA FACTCR

0.09945500 


\begin{tabular}{|c|c|}
\hline CASE & $H L W, P W R-U P, 100, W, W, A-C$ \\
\hline $\begin{array}{c}\text { DENSITY OF ACTINIDE } \\
\text { COMPOUNDS IN SOLUTIINN } \\
\text { (GM/CC) }\end{array}$ & $\begin{array}{l}\text { CRITICAL, FADIUS } \\
(C M)\end{array}$ \\
\hline $0.11080 E$ O2 & $0.12308 E$ O2 \\
\hline
\end{tabular}

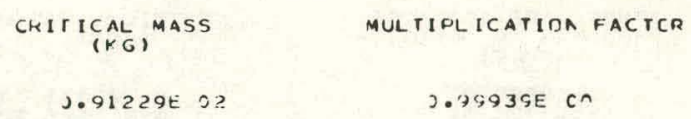

MULTIPLICATIDA FACTCR

J.3993GE CA

\begin{tabular}{|c|c|}
\hline \\
\hline $\begin{array}{c}\text { DENSITY OF ACTINIDE } \\
\text { COMPOUNDS IN SULUTION } \\
\text { (GM, CC S }\end{array}$ & CRITICAL RAUIUS \\
\hline 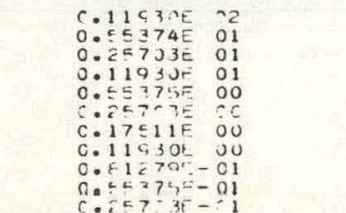 & 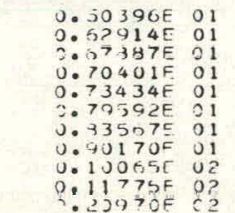 \\
\hline
\end{tabular}

MINIMUN SPITICAL MASC IS O.34715E JO KILTGPAMS

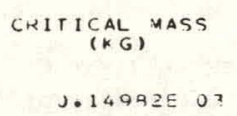

$0.92563 F$ on
MULTIPLICATIOA FACTCR

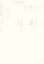




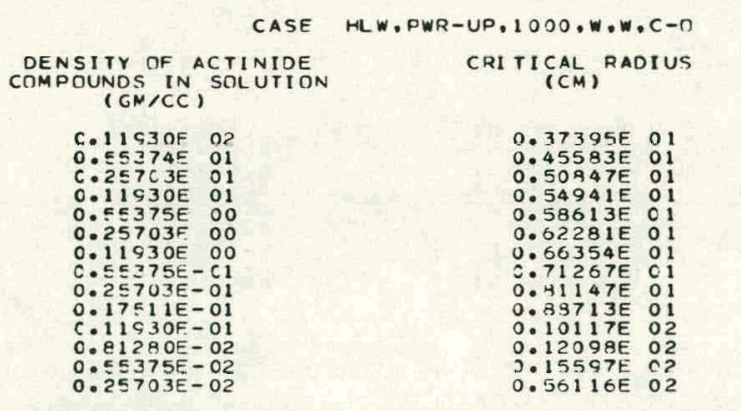

MINIMUM CPITICAL MASS IS 2.51214 E- 1 KILOGRAMS

\begin{tabular}{|c|c|}
\hline $\begin{array}{l}\text { DER SITY IF ACTINIDF } \\
\text { COMPOUNDS IN SOLUTIJN } \\
\text { (GN,CC) }\end{array}$ & $\underset{(C Y)}{C Q I T I C A L} \underset{(C A D I U S}{ }$ \\
\hline 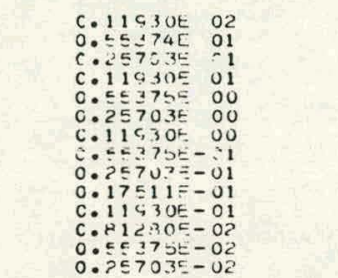 & 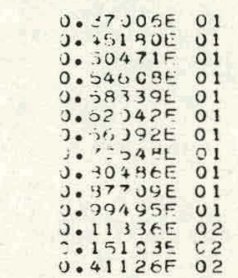 \\
\hline
\end{tabular}

MININUM CFITICAL MASS IS . 4 GLSF-"I KILIJGIAMS
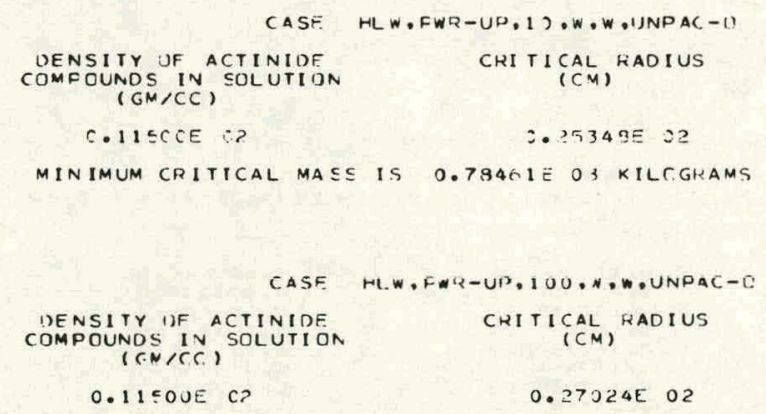

MINIMUM CRITICAL MASS IS $0.95073 E 03$ KILCCRAMS

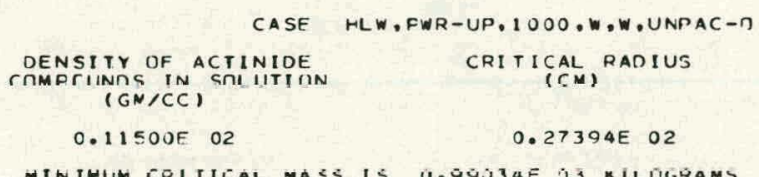

CASE HLW,FWR-UP, 10000 ,W,W, UNPAC-O

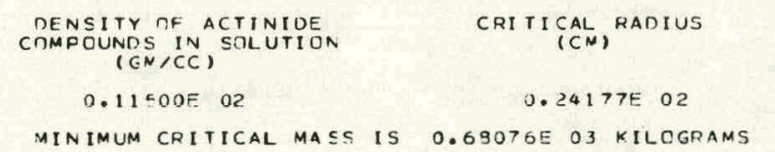

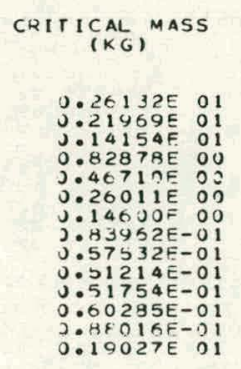

MULTIPLICATIOA FACTCR

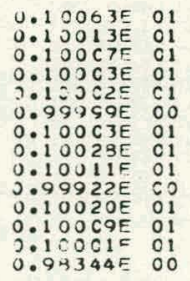

CKITICAL MASS

J.2: 325E 01

$\mathcal{J}, 21322 \mathrm{C}$ O

J.

J.4 THSOE C-

J. 257125 OO

$J .1<42$ 继 $J$

J. 314 I $35-J 1$

$0.561375-0$
$j .494955-0$

J.44223E-0

J.5 $31.461 \mathrm{E}-0$

ग.74

MULTIDLICATIOA F: ACTEW

3.1307550

J.1 UOITF= 01

j. 099 ç $3=0$ on

$01: 0: 1=01$

$0.100 C 2 E$ UI

J.1 00 J4F

$0.10011=01$

209543

$0.19324 E$ OI

j. 1.JCLE OI

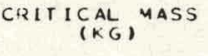

$3.784 \% 1=03$

CRITICAL MASS

$0.95073 E$ O3
MULTIPLICATIOA FACTCR

0.10003501
CRITIC (KG) $^{\text {MASS }}$

$0.99034 E 03$
MULTIPLICATION FACTCR

$0.100 C 2 E$ OI
CHITICAL MASS

$0.68076 E^{0.3}$
MULTIPLICATIOA FACTCR 


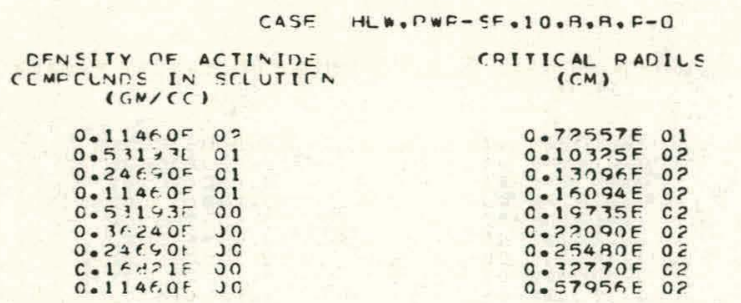

NIAIVIUU CFITICAL MACC IS O.1SZF ZE D? KILCGRAMS

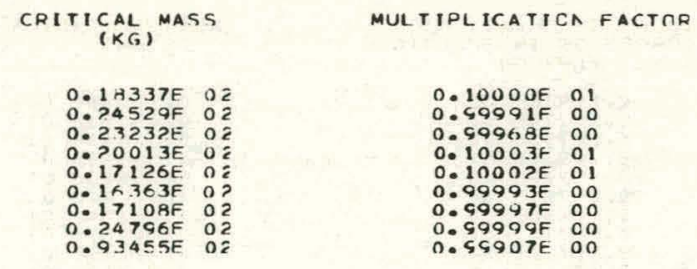

\begin{tabular}{|c|c|c|c|c|c|}
\hline 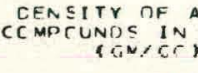 & $\begin{array}{l}\text { ACIINIDF } \\
\text { SCLUTICA }\end{array}$ & $\begin{array}{c}\text { CEITICAL } \\
(C M)^{R A C I U S}\end{array}$ & $\begin{array}{c}\text { CRITICAL MASS } \\
(K G)\end{array}$ & MULTIPLICATION & FACTחR \\
\hline $\begin{array}{l}0.11440 F \\
0.52142 F \\
0.24690 F \\
0.11460 E \\
0.53193 F \\
0.24190 F\end{array}$ & $\begin{array}{ll}0 & ? \\
0 & 1 \\
0 & 1 \\
0 & 1 \\
0 & 0 \\
0 & 0\end{array}$ & $\begin{array}{ll}0.72755 F & 01 \\
0.11092 F & 0 ? \\
0.14404 E & 02 \\
0.17712 F & 02 \\
C .01915 F & 02 \\
C .09420 T & 0 ?\end{array}$ & 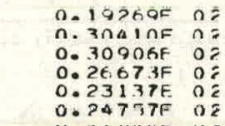 & 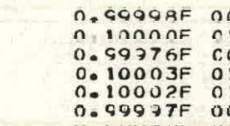 & $\begin{array}{l}1 \\
1 \\
0 \\
1 \\
1 \\
0\end{array}$ \\
\hline U. $1148 \mathrm{UP}$ & Ju & U. प्रक्रत्य U, & U. 41 HUSF & H. QUU उut at & ii \\
\hline
\end{tabular}

\begin{tabular}{|c|c|c|c|c|}
\hline $\begin{array}{r}\text { CEASITY } \\
\text { CCNECUNDS INA } \\
\text { CGNICC) }\end{array}$ & $\begin{array}{l}\text { ACTIVIDE } \\
\text { STIUTICA }\end{array}$ & $\begin{array}{c}\text { CRITICAL, PAOIUS } \\
(C M)\end{array}$ & $\begin{array}{c}\text { CRITICAL MASS } \\
\text { (KG) }^{\text {M }}\end{array}$ & MUL TIPLICATICA \\
\hline 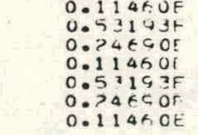 & $\begin{array}{ll}0 & ? \\
0 & 1 \\
0 & 1 \\
0 & 1 \\
0 & 0 \\
1 & 0 \\
0 & 0\end{array}$ & 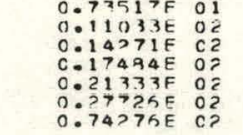 & $\begin{array}{ll}0.19075 E & 02 \\
0.24929 E & 02 \\
0.30061 F & 02 \\
0.256 .57 E & 02 \\
0.216 .34 E & 0= \\
0.220 \\
0.2043 E & 0 E \\
0.19472 F & 02\end{array}$ & $\begin{array}{l}0.95966 F \\
0.100006 \\
0.56975 F \\
0.10005 F \\
0.10002 F \\
0.59997 F \\
0.99607 F\end{array}$ \\
\hline
\end{tabular}

NINIMUM CRITICAL MASS IS O.1COTFF O? KILTGFAMS

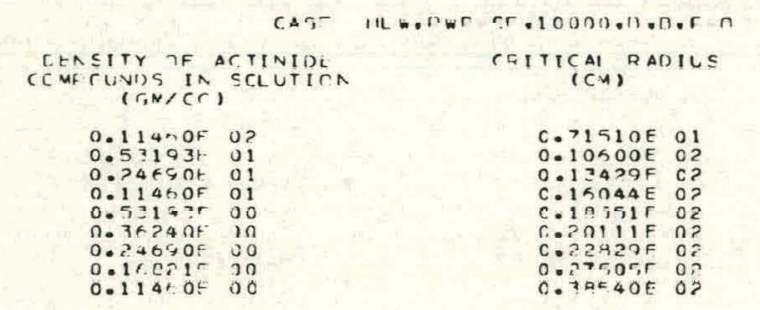

NINIMUM CRITICAL MACS IS 0.1\%20SF O? KILCGRAMS

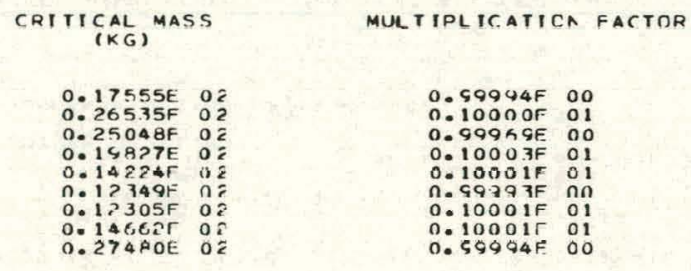

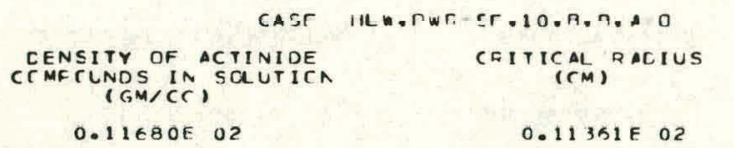

mia tMum cFitical mass is o.717ase o? Kiltgrams

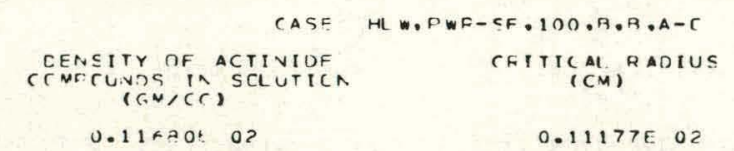

NINIMUM CRITICAL MASC IS D.EFICFE OD KILTEFAMS

\section{CRITICAL MASS}

$0.71745 E$ oz

CRITICAL MASS
(KG)

0. SB.30RE OE
MULTIPLICATIOA FACTOR

$0 . \$ 9999 F \quad 00$ 


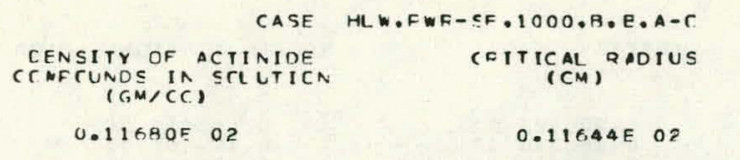

NIR IMUM CFITICAL MASS IS 0.772 $3 F$ O2 KILCGRAMS

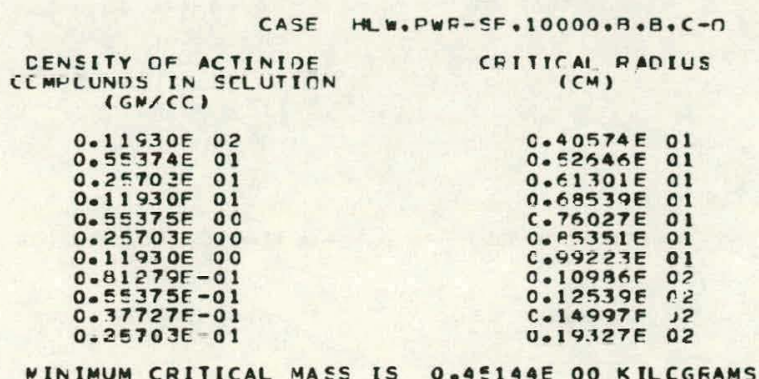

CRITICAL MASS

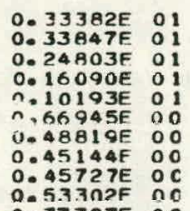

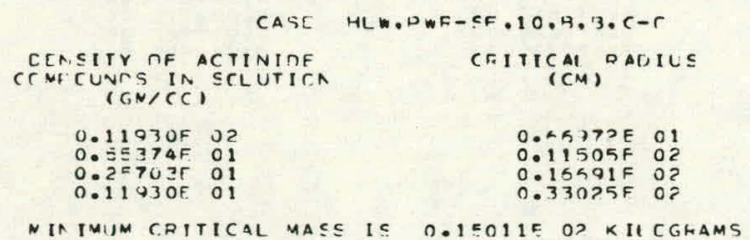

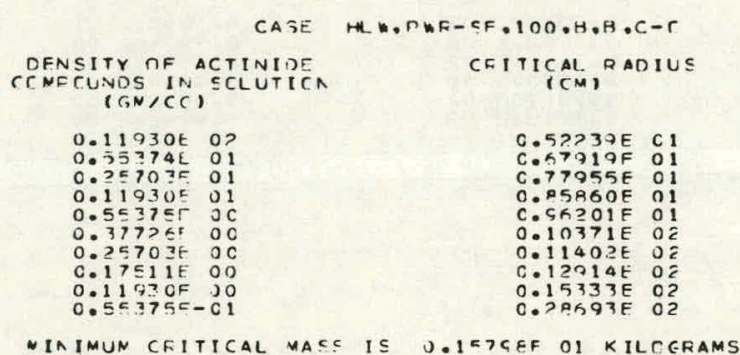

CRITICAL MASS

$0.15815 E \quad 02$

CRITICAL NASS

$0.15011 \mathrm{~F}$ 02

$\begin{array}{ll}0.50061 F & 0 \text { ? } \\ 0.18000 F & 03\end{array}$

CRITICAL MASS

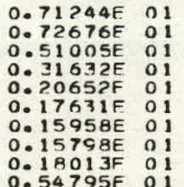

CRITICAL MASS

0.310565 o1

$0.35049 F$ ol

$0.25499 \mathrm{~F}$ ol

$0.16484 \mathrm{E}$ :

$0 . \in P E S K F$ OC

$0.47076 E$ DC

$0.4 P 313 F$ OC

$0.8,145 E$ CO

NINIMUM CFITICAL MasS IS 0.47C.7EF DO K IL CGFAMS

WINIMUM CRITICAL MASS IS O.ASIA4E OO KILCGFAMS 


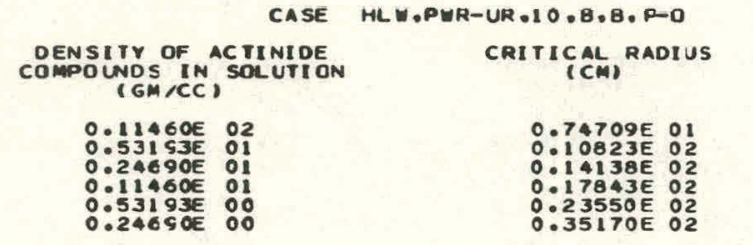

MINIMUM CRITICAL MASS IS 0.20018E O2 KILOGRAMS

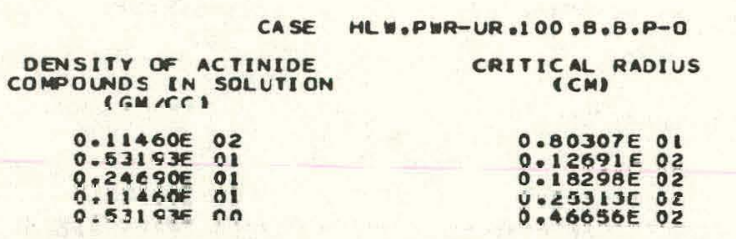

MINIMUMA CRITICAL MASS IS 0.24863E O2 KILOGRAMS

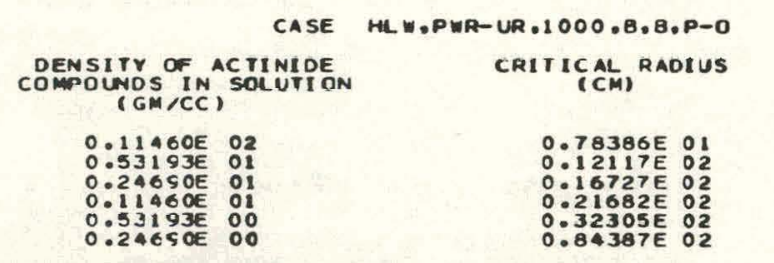

MINIMUM CRITICAL MASS IS 0.23121E 02 KILOGRAMS

\begin{tabular}{|c|c|c|}
\hline $\begin{array}{r}\text { RFNSITY RF } \\
\text { COMONINRS IN } \\
\text { ( GM } C C \text { ) }\end{array}$ & $\begin{array}{l}\text { ar TININF } \\
\text { SOI TITION }\end{array}$ & CRITICCAL RADIUS \\
\hline $\begin{array}{l}0.11460 E \\
0.53193 E \\
0.24 E 90 E \\
0.11140 E \\
0.53193 E \\
0.36240 E \\
0.24690 E \\
0.16821 E \\
0.11460 E\end{array}$ & $\begin{array}{ll}02 & 2 \\
0 & 1 \\
01 & 1 \\
01 & 1 \\
0 & 0 \\
0 & 0 \\
0 & 0 \\
0 & 0 \\
0 & 0\end{array}$ & 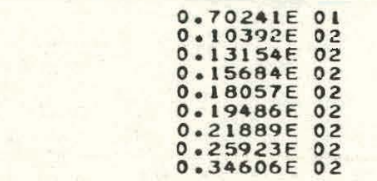 \\
\hline
\end{tabular}

MINTHIIM CRITICAL MASS IS O.10847E O2 KILOGRAMS

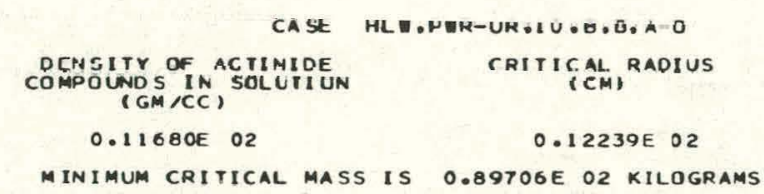

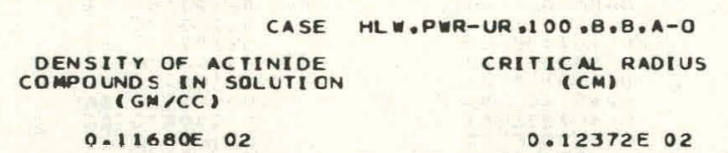

MINIMUM CRITICAL MASS IS 0.92656 E O2 KILOGRAMS

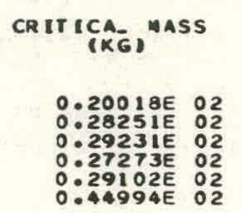

MULTIPLICATION FACTOR

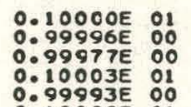

$0.100993 E$ OD

O. 10000 OL

CR IT ICAL, MASS

$0.24863 E$ O2

$0.03361 E$ UL

$0.77663 E^{03}$

CAIT ICAL MASS

$0.23121 E \quad 02$

$0.39639 E$ E2

$0.48406 E$ O2

$\begin{array}{ll}0.75123 E & 02 \\ 0.752151 E & 03\end{array}$
MU TIPLICATION FACTOR

$0.10002 E$ OI

0.909070

ก. $0999 K F$ O०
MUR TIPLICATION FACTOR

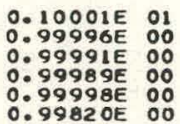

$0.10001 E$ O1 $0.99991 E$ OO $0.99820 E$ OO

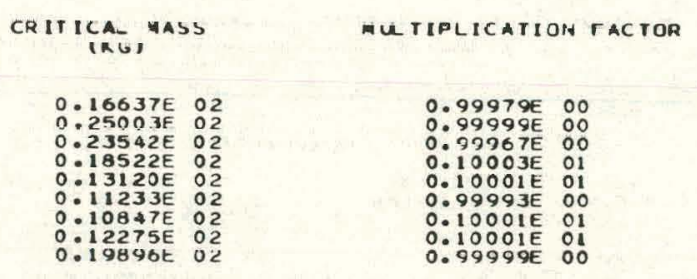

CRITICAL, MASS

$0.89706 E \quad 02$

MUE TIPLICATION FACTOR

$0.99947 E 00$
MULTIPLICATION FACTOR

0.99930 OO 


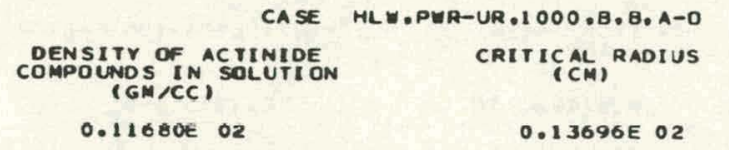

MINIMUM CRITICAL MASS IS 0.12569E O3 KILOGRAMS

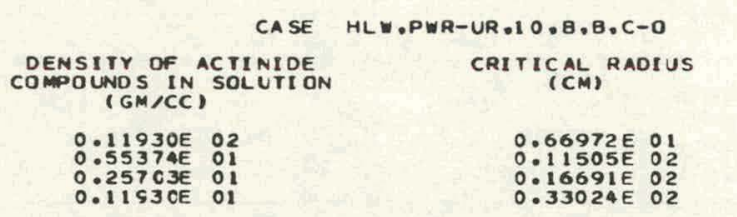

MINIMUM CRITICAL MASS IS 0.15011E O2 KILOGRAMS

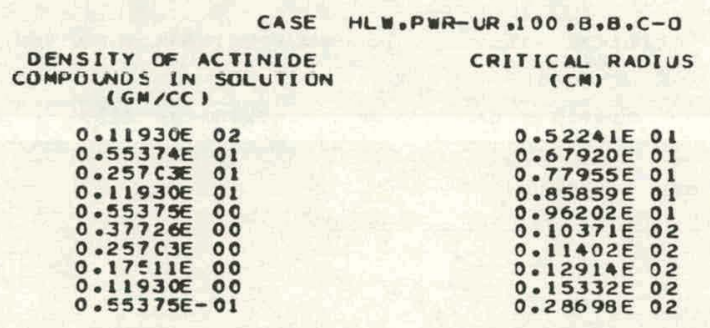

MINIMUM CRITICAL MASS IS 0.15799E OI KILOGRAMS

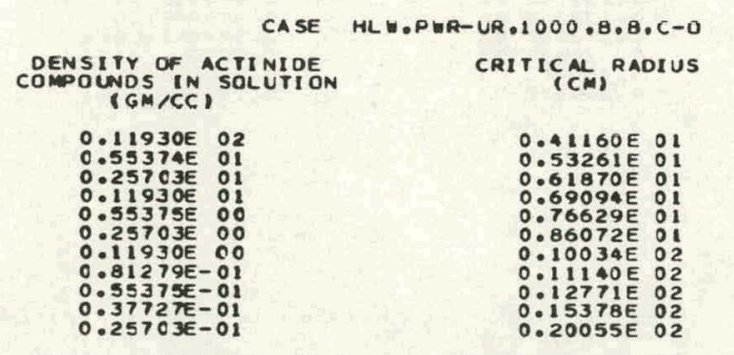

MINIMUM CRITICAL MASS IS 0.47OT5E OO KILOGRAMS

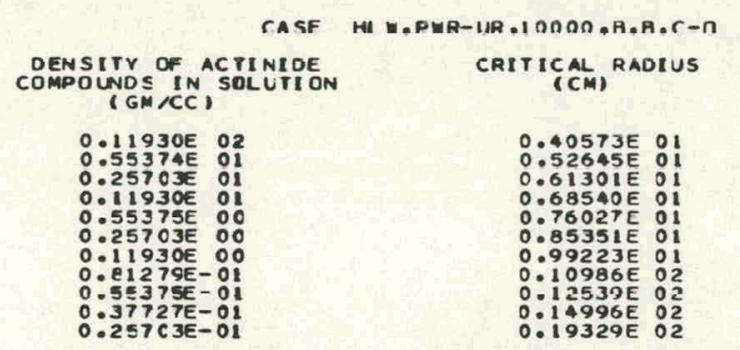

MINIMUM CRITICAL MASS IS 0.45145E OO KILOGRAMS

$$
\begin{gathered}
\text { CRITICAL MASS } \\
0.12569 E \text { O3 }
\end{gathered}
$$

MU TIPLICATION FACTOR

$0.99565 E 00$
CR IT ICAL UASS

$0.15813 E \quad 03$

CRITICAL ${ }_{(K G)}^{\text {MASS }}$

$0.15011 \mathrm{E} \quad 02$ $\begin{array}{lll}0.17999 E & 03\end{array}$

CRITICA: MASS

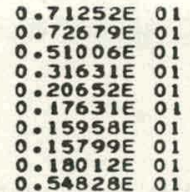
CRITICALL, WASS

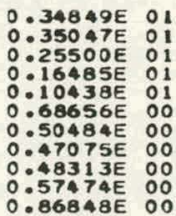

$0.86848 E$ OO

CRIT ICAL, NASS

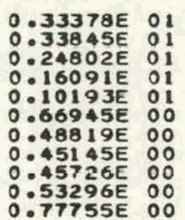

MU TIPLICATION FAC TOR

$0.99016 E 00$

MULTIPLICATION FAC TOR

$0.99941 E 00$ $0.99999 \mathrm{O}^{0}$
MU TIPLICATION FACTOR

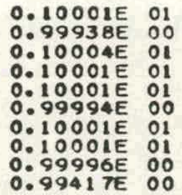

MU TIPLICATION FACTOR

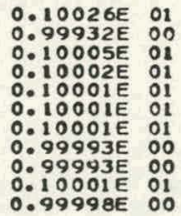

MUTIPLICATION FACTOR

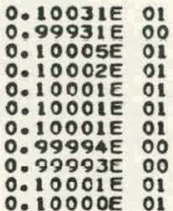




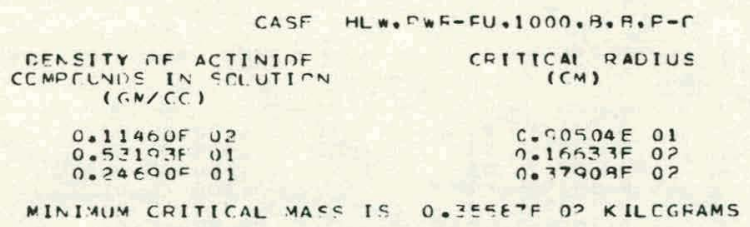

\begin{tabular}{|c|c|}
\hline CASE & HLW, PWE-DU, $10000, B, B, F-D$ \\
\hline $\begin{array}{l}\text { DENSITY OF ACTINIDE } \\
\text { CEMPCUNDS IN SOL UTICN } \\
\text { (GN, CC) }\end{array}$ & $\begin{array}{l}\text { CEITICAL RADIUS } \\
\text { (CM) }\end{array}$ \\
\hline 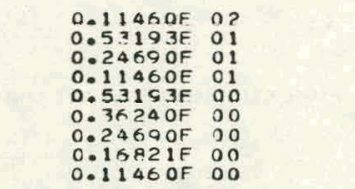 & 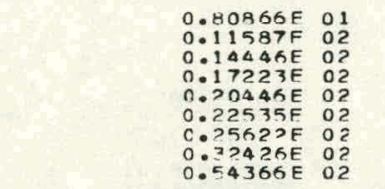 \\
\hline
\end{tabular}

NINTMUM CFITICAL MASS IS 0.1777AE O? KILCGRAMS

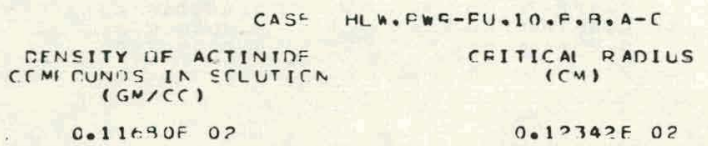

$$
\text { CRITICAL MASS }
$$

$0.355 R 7 L$ o? $0.56342 \mathrm{~F}$ 0.

$\underset{\text { CRITICAL MASS }}{\text { (KG) }}$

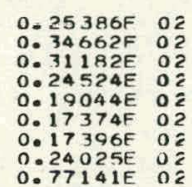

$0.24025 E$
$0.77141 \mathrm{O}$

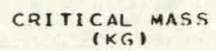

$0.91583 E$ 02

$\underset{\text { CRITICAL MASS }}{\text { (KG) }}$

$0.98508 E$ O.

CRITICAL MASS

$0.13936 \mathrm{EE} \quad 0.3$

CRITICAL MASS

$0.25506 \mathrm{~F} \quad 03$
MULTIPLICATIOA FACTRR

$0.10011 \mathrm{~F}$ U1 D. G९R1 4 F

MUL TIPLICATIOA FACTOR

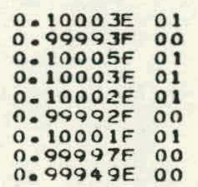

MULTIPLICATIOA FACTOK

$0.90932 F 00$

MULTIPLICATIOA FACTOR

$0.99884 E 00$

MULTIPLICATIOA FACTCR

$0.99375 E$ O0

MULTIPLICATIOA FACTCF

$0.10003 E 01$

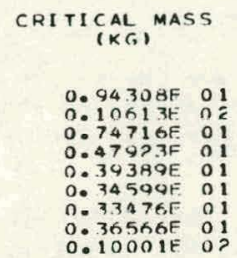

MIU TIPLICATION FACTOR

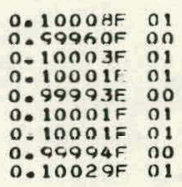




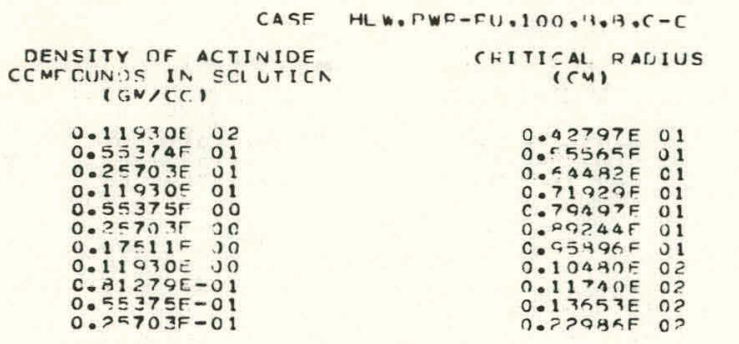

NIAIMUM CRITICAL MASS IS O.ESCEEF ON KILCERAMS

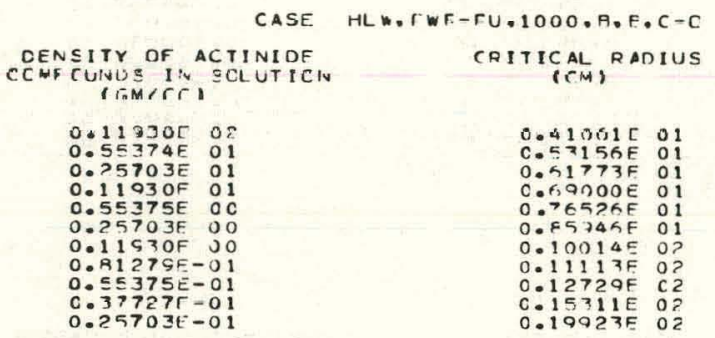

MINIMUM CRITICAL MASS IS O.4ETZOF DO KILLEFAMS

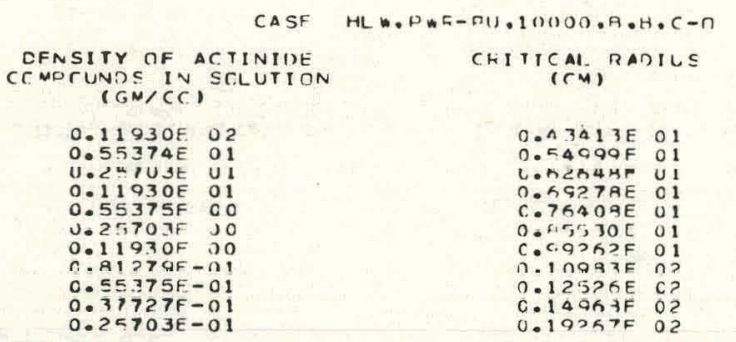

MINIMUM CRITICAL MASS IS O.AFICEF OC KILCEFAMS $\underset{\text { CRITICAL MASS }}{(K G)}$

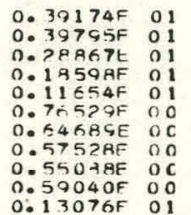

$\begin{array}{lll}0.59040 F & 0 \\ 0.13076 F & 01\end{array}$
MIR TIPL ICATIOA FACTRR

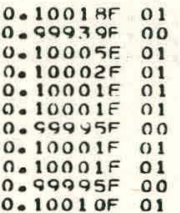

0.9093 GF 00

- io

10001F

. c99y5F Do

$0.10001 \mathrm{~F} 01$

0.1001 of 01

CRITICAL MASS

(Ria)

ô. $34=975$ Ò 1

$0.34939 E$ O

0.253 AOF 01

$0.10396 F$ O 1

. $58355 E$ OC

0.501 TRF OC

$0.46730 E$ OO

0.478?or

$0.85146 \mathrm{~F} 00$
MULTIPLICATIOA FACTOR

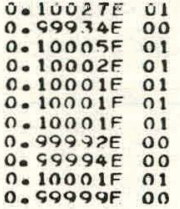

$0.99934 E$ OO

O.10005F 0

$0.10001 E$ O

$0.10001 F$ IF

. $99994 \mathrm{E} O$

0. 99999F on

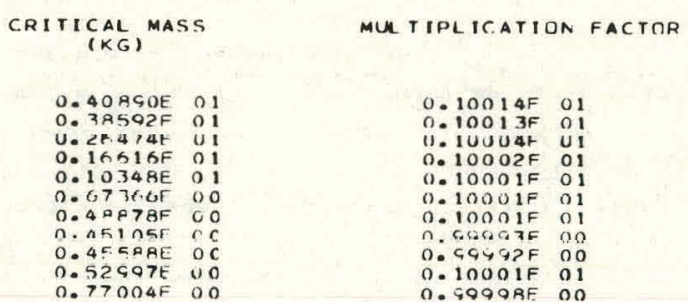

CRITICAL MASS

$0.30480 F$ O

C.19496F 0

MINIVUN CRITICAL MASS IS O.JCAFOF O3 KILCGFAMS

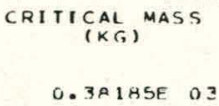

$0.3 \times 185 E$ O3

C. $15232 \mathrm{~F} 02$

UINIMUM CFITICAL MASS IS O. 3EIEEF O3 KILCGFAMS

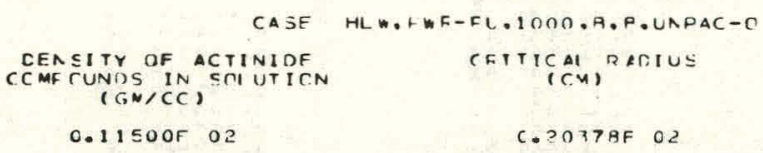

INIMUM CRITICAL MASS IS O.ACTETF O3 KILCGEAMS $\underset{\text { CRITICAL MASS }}{\text { (KG) }}$

$0.90767 E \quad 03$
MILLTIPLICATIOA FACTCR

$0.10000 \mathrm{~F}$

MILTIPLICATIOA FACTCR

$0.10005 F$ O1

MUR TIPI ICATIOA FACTCF

$0.10003 E$ Q 1 


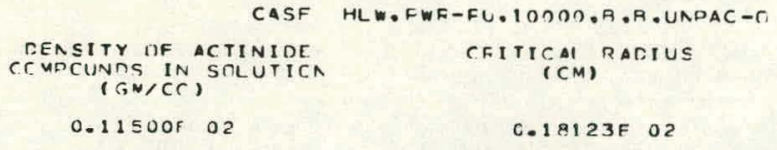

NINIMUM CRITICAL MASS IS O.EEG73F 03 KILCGFAMS

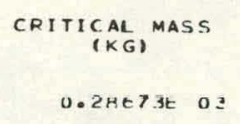

MULTIPLICATIOA FACTRE

0.10000 O 1

MUL TIPI ICATICA FACTCF

$0.10002 \mathrm{~F} 01$
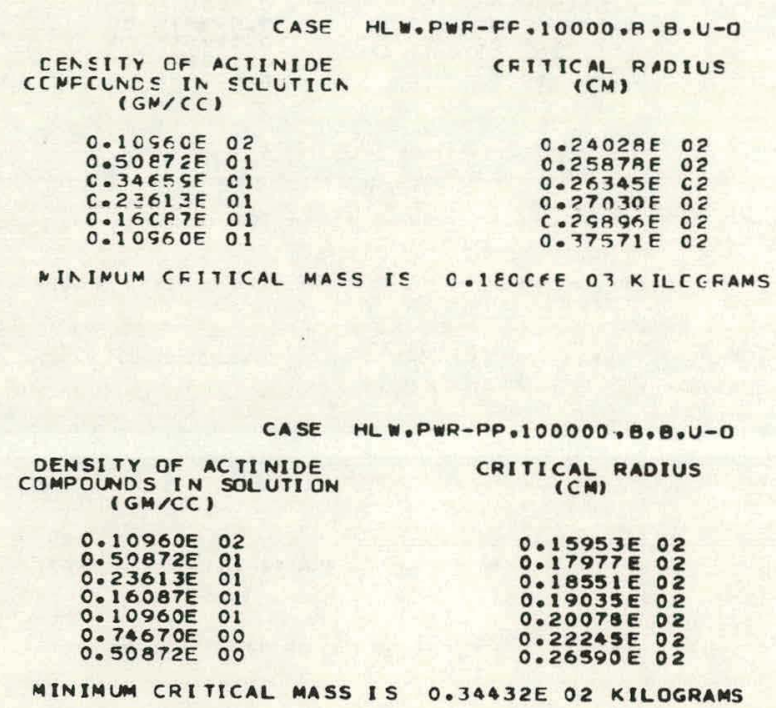

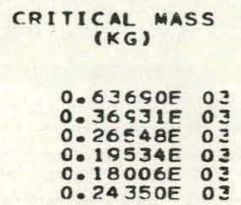

MULTIPL ICATIOA FACTOR

$$
\begin{aligned}
& 0.99973 F \text { OO } \\
& 0.10000 E \text { OI } \\
& 0.10000 E \text { OI } \\
& 0.10000 E \text { OI } \\
& 0.14996 E \text { OO } \\
& 0.1000 \text { O O1 }
\end{aligned}
$$

\section{CRITICAL MASS

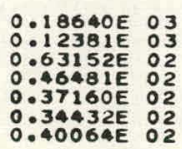

CRITICAL MASS
(KG)

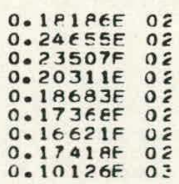

$0.24 E 55 E$ O $0.23507 F$ O2 $0.18683 \mathrm{E}$ O? $1736 \mathrm{EF}$ O $0.17418 F$ OE

-iataun cFitical mass is o.jefele o? kilcgrams

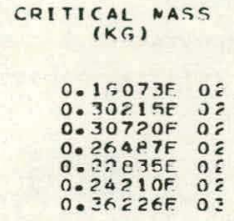

MULTIPLICATION FACTOR

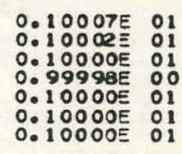

MULTIPLICATIOA FACTHR

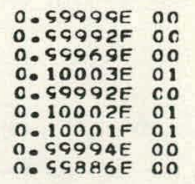

MULTIPLICATICA FACTRP

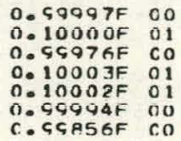




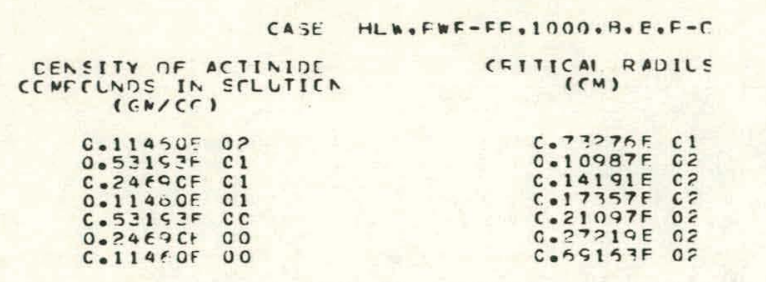

NINIMUN CFITICAL UASS IS O. IFfEEF OO KILCGEAMS

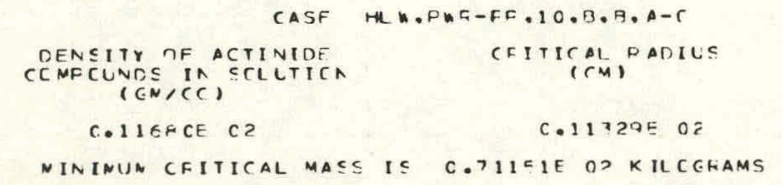

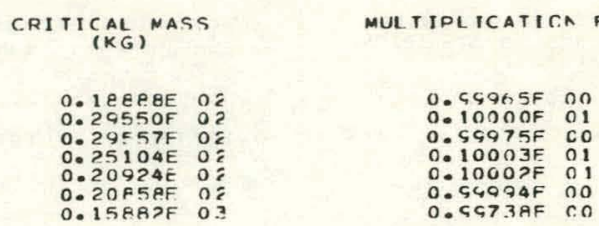

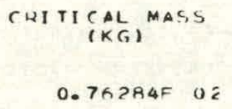

MILTIPI ICATISA FACTCF

$0.9 S 44$ IF 00 Ö.çOSFF OC $\begin{array}{ll}0.4994 P F & 0 \% \\ 0.99931 F \text { on }\end{array}$ 


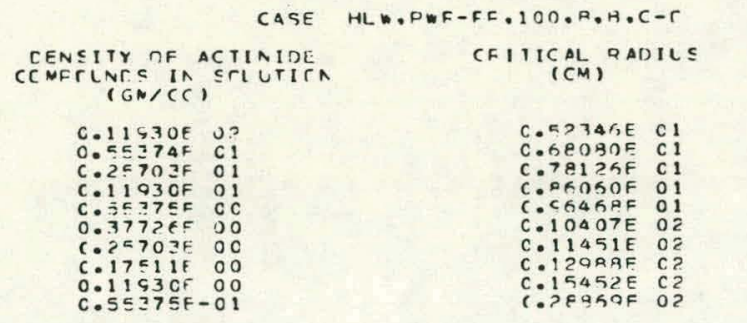

NIAINUN CFITICAL MASS IS O.1FOTOF O1 KILCGFAMS

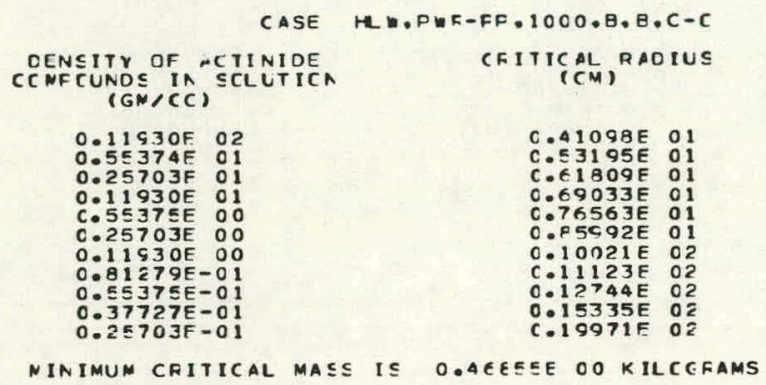

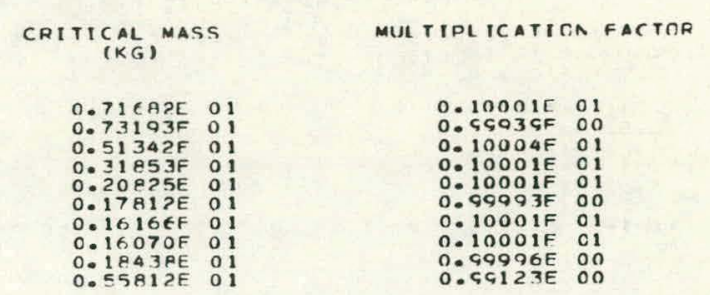

CRITICAL, MASS

MULTIPLICATIER FACTEF
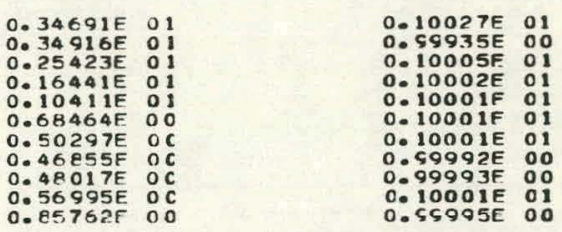

CRITICAL MASS
(KG)

$0.332 G E F \quad 01$

$0.3,772$ E 0

$0.247+0 E$ O

O. $1017 \mathrm{EE}$ O 1

$0.66,840 F$ OO

ก. $4 P 718 E$ OC

$0.450>8 F$ G

$0.45571 F$ OC

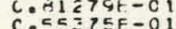

$0.5703 F-C 1$
$0.37757 F-01$

C.1077>

$0.14 G 73 E$ C?
C.1 15 STE C?

NIAINUN CFITICAL MASC IS C.AECEAE OO KILCGFAMS
CRITICAL, MASS

$0.43355 F$ oz

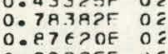
$0.80525 E$ U $\begin{array}{ll}0.00189 F & 0 E \\ 0.36,681 \mathrm{E} & 03\end{array}$ $0.5337 \mathrm{SF}$ Ca

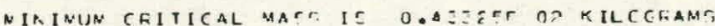

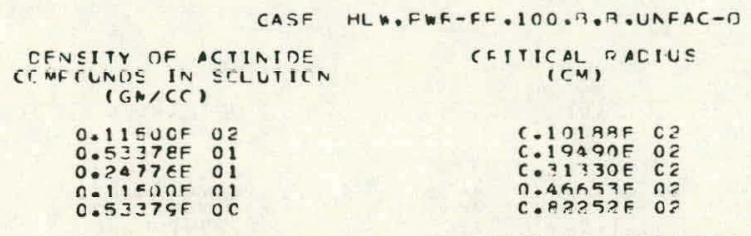

nininun cFitical mass ts o.jeclef o? killcgiams

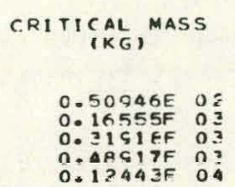

MUR.TIPLICATICA FACTCE

$0.59956 F$ OO $0.49751 \mathrm{~F}$ on n. $994 G$ AF
0.59787 OC
$0.10032 \mathrm{~F} \mathrm{C1}$

$0.59934 E$ OO

O. 10002E OI

$0.10001 \mathrm{~F}$ O

$0.10001 F$ I

$0.59993 F$
$0.99993 \mathrm{O}$

$0.10001 \mathrm{~F}$

. दC917F 00

0. $5990 \mathrm{~F}$ CO

0. $59991 \mathrm{~F}$ ON

O. ऽऽ $924 \mathrm{~F}$ OO 


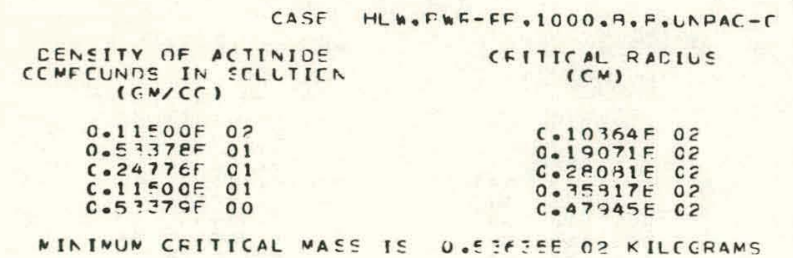

CAS $=$ HLW,FWF-FD, $1 C C O O, A, A, L N P A C-O$

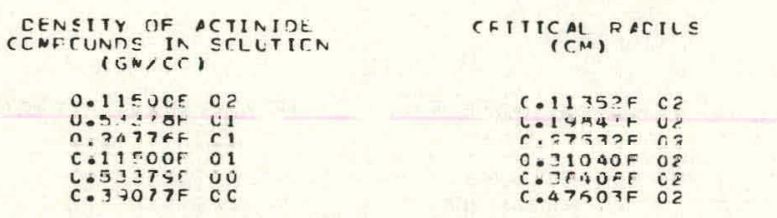

NIAIMUN CFITICAL MASS IS O.7CATCE C? KILCGFAMS

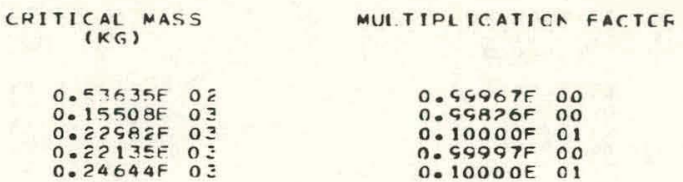

MUITIPLICATICA FACTCF

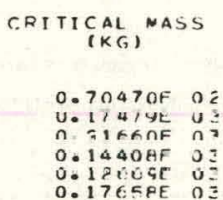

0.7047 OF OZ
U. 1 $74, Y$ U

$0.1440 A F$ O

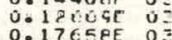

$0.44949 F$ UO n. KGQQTF $\mathrm{OC}$ 0.1000 or
011
$0.10001 \mathrm{~F}$

\begin{tabular}{|c|c|}
\hline CASE & HLW ${ }_{0} P W R-U P .100000 \cdot B, B \cdot U-0$ \\
\hline $\begin{array}{c}\text { DENSITY OF, AC TINIDE } \\
\text { COMPOUNDS IN SOLUTION } \\
\text { (GM,CC) }\end{array}$ & CRITI CAL RADIUS \\
\hline 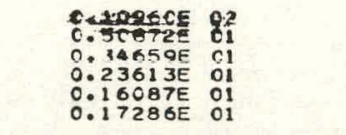 & 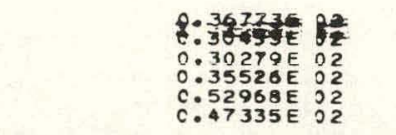 \\
\hline
\end{tabular}

MINIMUM CRITICAL MASS IS $0.40305 E$ O 3 KILOGRAMS

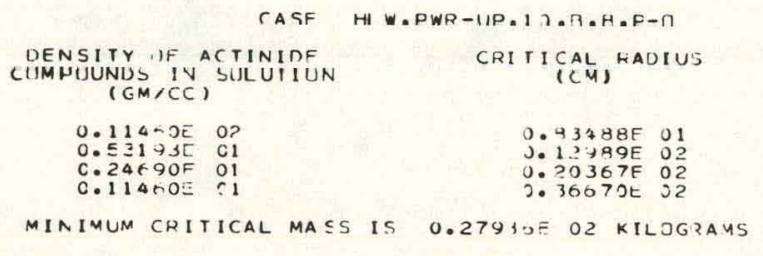

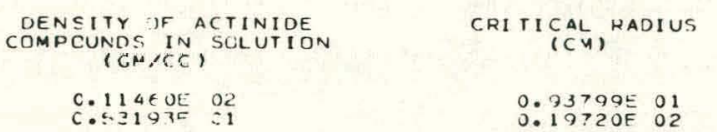

\section{CRITICN ${ }_{(K G)}^{\text {MASS }}$ \\ 20.20073 $0.40305 E$ O3 $\begin{array}{lll}0.44352 E & 03 \\ 0.10014 E & 04\end{array}$ \\ $0.76801 E 03$}

MULTIPLICATI JN FACTOR

\section{p.tepor $c 1$. 0.99998 F 00

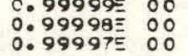




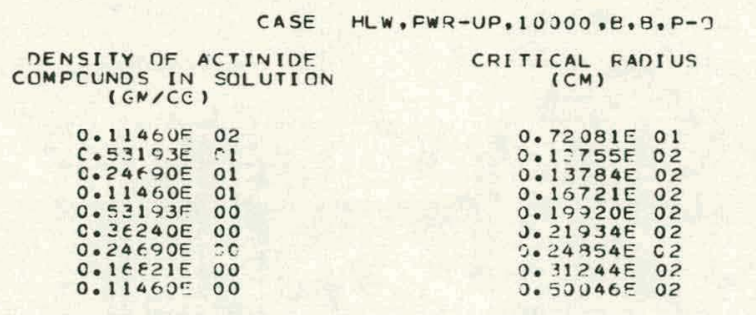

MINIMUN CRITICAL MASS IS 0.15878E O2 KILOGRAMS

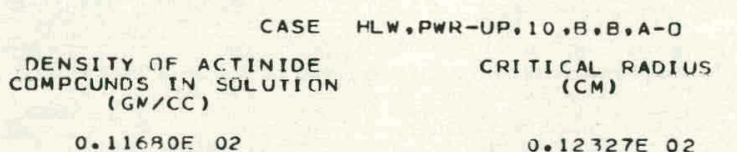

MINIMUM CRITICAL MASS IS $0.91659 E$ O2 KILOGRAMS

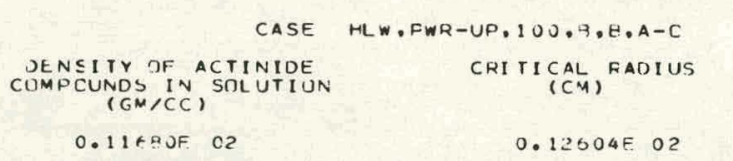

MINIMUM CHITICAL MASS IS $0.97904 F$ O? KILOGPAUS

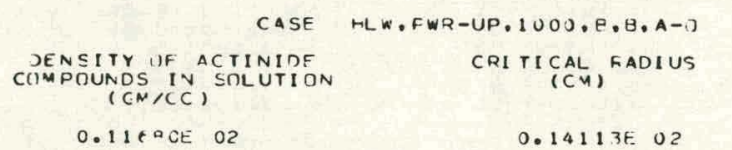

MININUN CQITICAL MASS IS C.13752E 03 KILOGRAMS

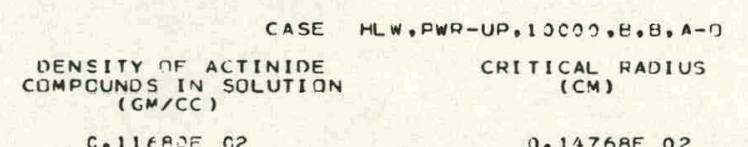

MINIMUM CRITICAL MASS IS O.15759E U3 KILOGRAMS

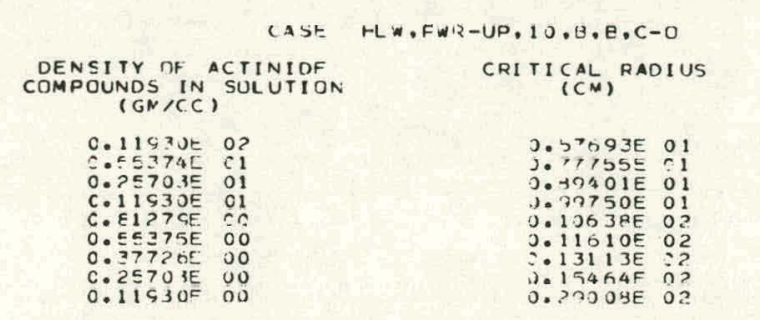

MINIMUM CHITICAL MASS IS 0.35535E OI KILOGRA.13
CRITICAL, MASS

J.17379:0?

$3.27716 E$ ?

$0.27097 \mathrm{OE} 0 ?$

. 22445E ?

J.17612E O

Jiग

J.214915 02

J.:OU173E O?

CRITICAL MASS

J.91658E 02

CRITICAL MASS

$J .97 \rightarrow 64 E \quad 02$

CRITICAL (KG) $^{\text {MASS }}$

0.1375?5 0?

CRITICAL $\underset{(K G)}{\text { MASS }}$

J.15759E O?
J.6,00295 00

MULTIPLICATION FACTCR

$0.99934 \mathrm{~F} \quad \mathrm{CO}$

MULTIPLICATIOA FACTCL

$0.39492 F \mathrm{GO}$

MULTIPL. ICATIOA FACTCR

$0.934 \mathrm{CF}=00$

MULTIDL ICATIOA FAC.TCR
MULTIPLICATIOA FACTCK

$0.95765=01$

ग. $16735 E$ O2

J. $76932 \mathrm{E}$ O1

J.49502E OI

$0.40391 E$ OI

J. 36 $301 E$ OI

0.393145 O1
D.1 UUCRE OI

J.3 $362 E$ OO

O.10OO3E OI

3.1COC1E 21

J.99992E 00

. gygaje co 


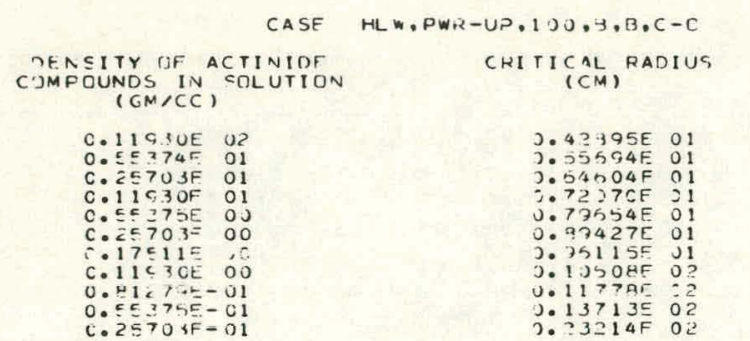

MIVIMUM CIRITICAL MASS IS O.JitSBSE OJ KILOG IAMS

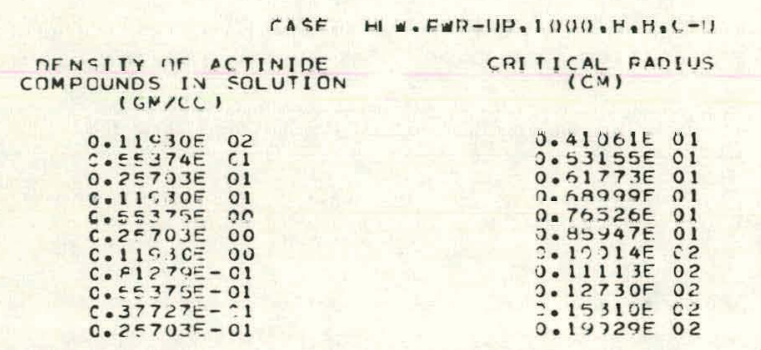

MINIMUM CRITICAL MASS IS 0.4573 BE OJ KILOGRAMS

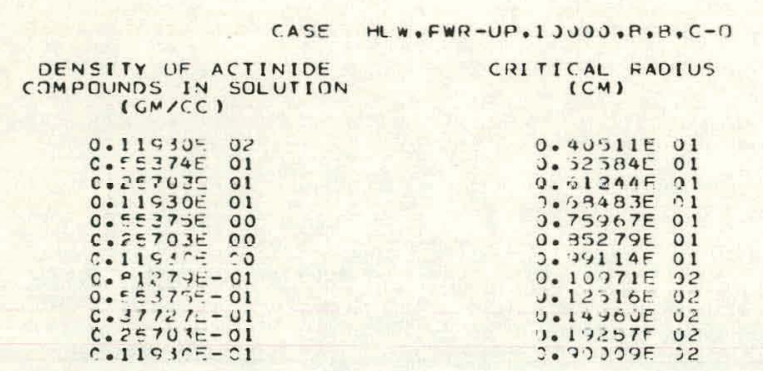

MINIMLM CRITICAL MASS IS 0.44958500 KILCGRAMS

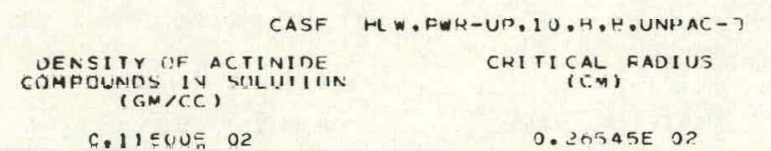

MINIMLM CRITICAL MACS IS 0.901J9E O3 KILOGHAYS

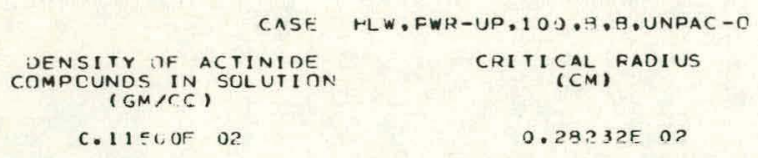

MINIMUM CRITICAL MASS IS 0.1084 OE O4 KILOGRAMS
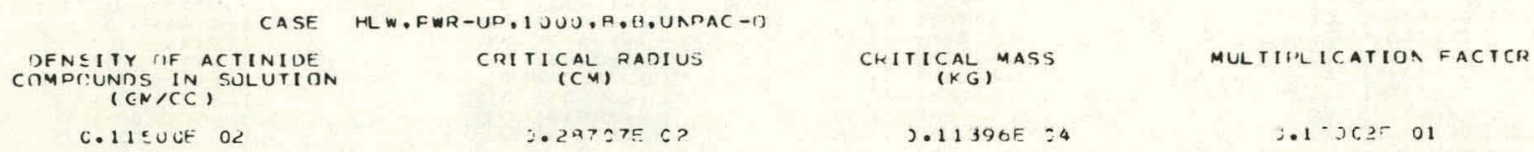

CRITICAL MASS

U. 54 गयम U

j.343395 31

$\checkmark .164175$

$0.10395 E$
$0.68358 E$

¿.5r 1895 O

J.47450E

U. $.56718 \mathrm{~F}$ 0O

CRITICAL MASS

J.3 3226: 01

J. $33727 E$
J. 34731

$3.16 .051 \mathrm{E} 0$

J.10167E OI

J.4 fio 595 o?

J.44759E 0

$30.4<$,

3.71 . $3[$ J 00
J.36 $443 \mathrm{~F}$

CRITICAL YASS

1.90103509

MUL RIPLICATION + AC IIIR

0.1 u 02501

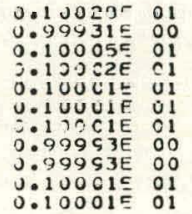

MULTIPLICATIOA IA ATCK

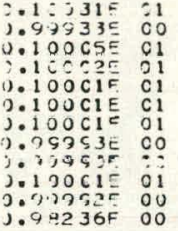

J.94236F 00
MULTIPL ICATIOA FACTCR

$0.10002 E: 1$
3. $\begin{aligned} & 1 \\ & 0.35 F\end{aligned}$

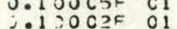

0.1 U0 CIE CI

1 1 UOC1E O1

3.959955
$0.10014=01$

MULTIPLICATIOA FACTCR

MINIMLM CHITICAL MASS IS $0.11396 E 04$ KILUGRAMS 


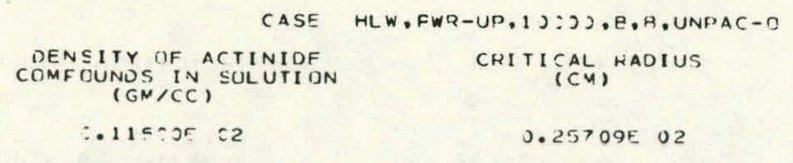

MINIMUN CHITICAL MACC IS 0.8185 JE O3 KILIJGRAMS

$$
\begin{gathered}
\text { CRITICAL MASS } \\
\text { (KG) } \\
0.81955503
\end{gathered}
$$

MULTIPL ICATIIOA FACTCR

0.1 J0G15 01

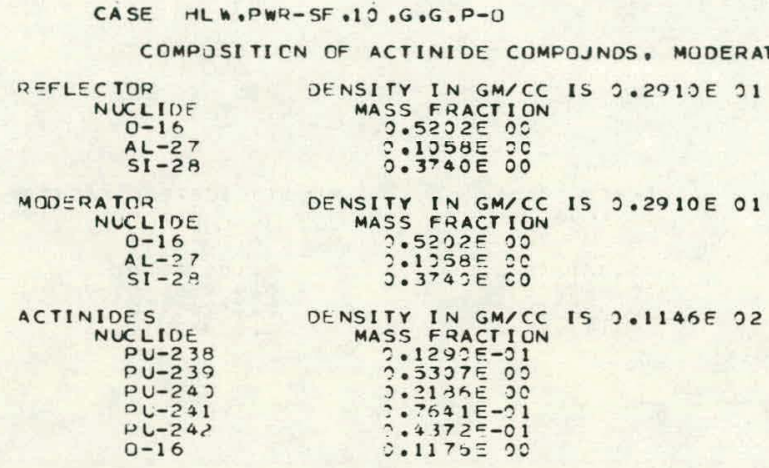

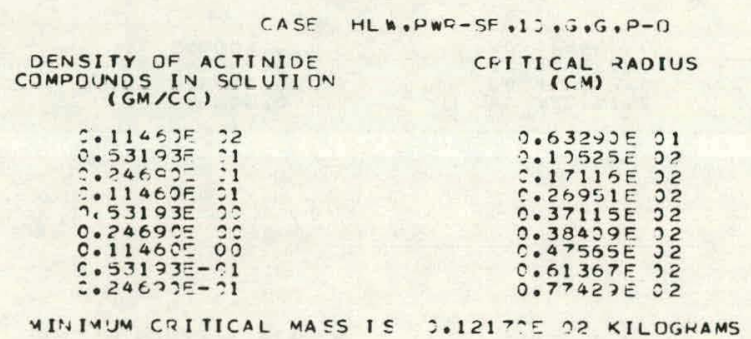
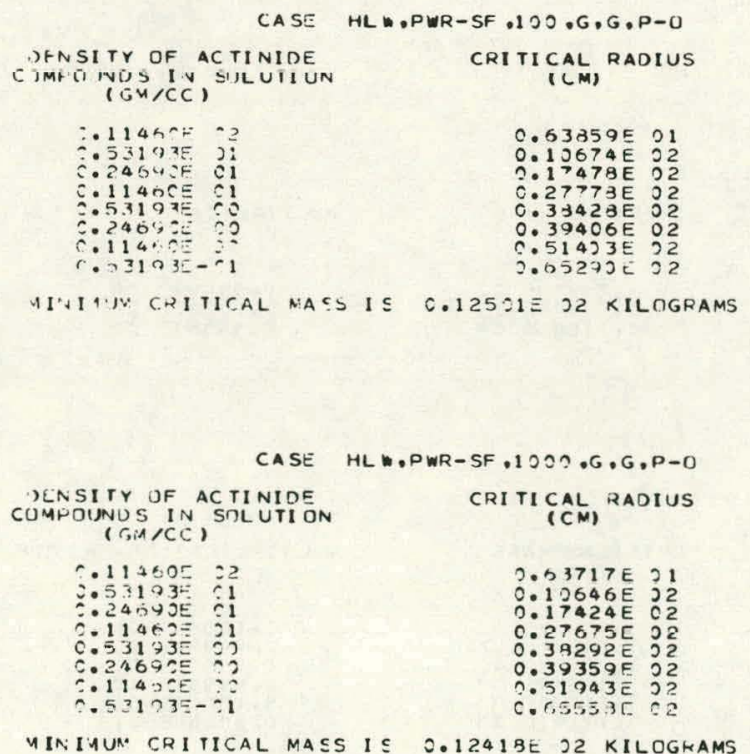

$$
\text { CRITICAL MASS }
$$

ว. 1217 CE 22 $0.25977 \mathrm{~F}$ ग2
$0.51864 \mathrm{E} C 2$ 0.93979 E 02 $311392 \mathrm{E} 03$ 0.5960 $0.51661 \mathrm{E}$ $0.51495 E$ O2
0.4 . $13 E$ O?

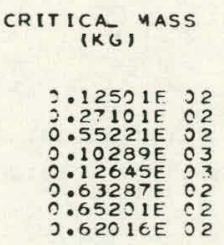
MINIAW CRITICAL NACS I $0.12501 \equiv$ ग2 KILOGRAMS

MINIMUN CRITICAL MASS IS 0.12418E J2 KILOGHAMS

\section{CRITICA-, MASS}

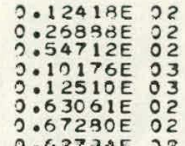

MUL TIPLICATION FACTOK

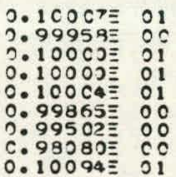

MULTIPLICATIJN FAC TOP

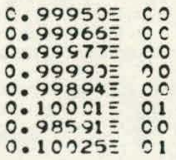

MULTIPLICATIJN FAETOR

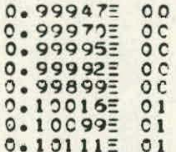



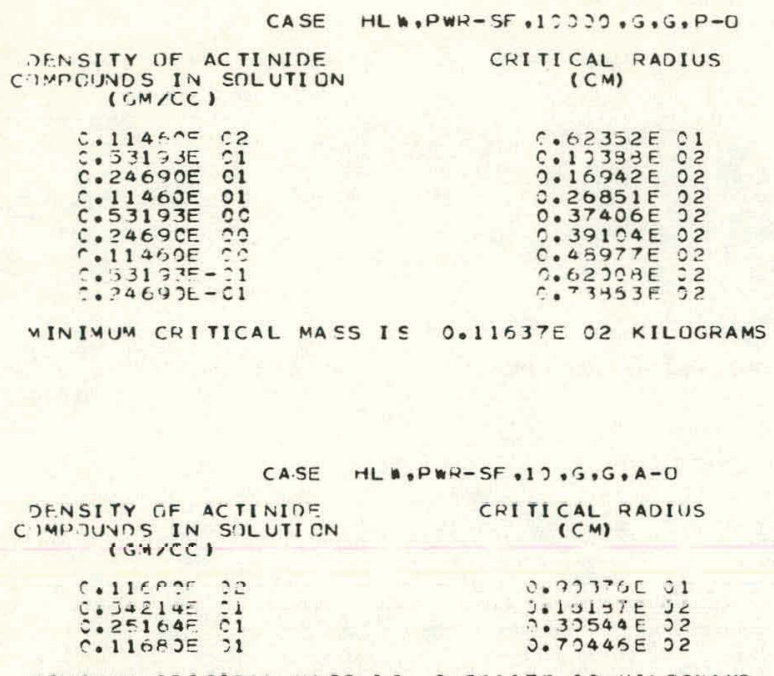

MINIMIUM CRITICAL MASS IS 2.36117 J? KILOGRAMS

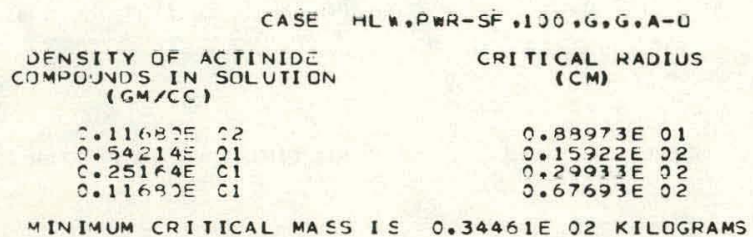

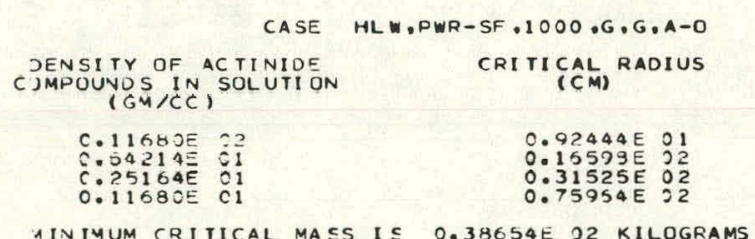

$$
\begin{aligned}
& \text { CRITICA } \text { (KG) }^{\text {MASS }} \\
& 311637 E \text { O2 } \\
& \text { З.:2478CE O2 } \\
& 0.92939 E \text { O2 } \\
& 0.11663 E \text { O } 3 \\
& , .61843 E \text { O2 } \\
& \begin{array}{l}
0.564211 \\
\hdashline .53126 E
\end{array} \\
& \text { 广.53126E O2 }
\end{aligned}
$$

$$
\text { CRITICAL MASS }
$$

O.J011-5 0 8

O. Y03 30근 J2

D.17105E 04
MULTIPLICATION FAETOR

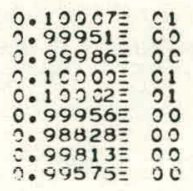

MULTIPLICATION FAETOR

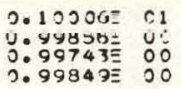

\section{CRITICAL MASS \\ $0.34461 E \quad 02$ J.91669E J2 0.15177 E 04}

CRITICN WASS

$0.38654 \mathrm{E} 02$ $0.10394 \mathrm{E} O 3$ $\begin{array}{ll}0.33025 E & : 3 \\ 0.21448 E & 04\end{array}$

AINIMUM CRITICAL MASS IS 0.38654E O2 KILOGRAMS 


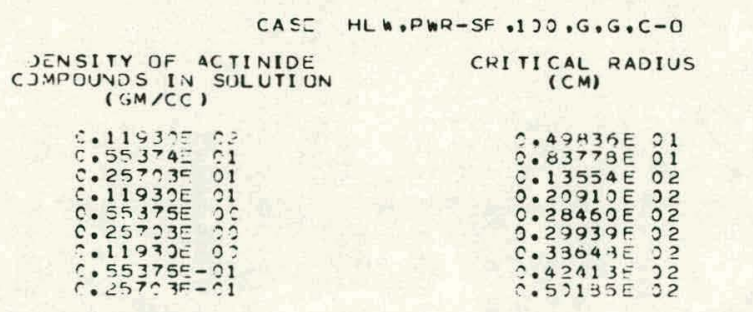

AINIAUM CHITICAL MASS I 0.51856 DI KILOGRAMS

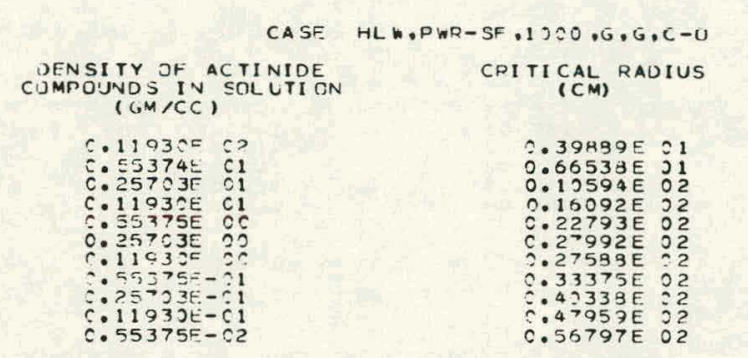

MINIMUP CRITICAL MASS I 0.3171 9E $I$ KILOGRAMS

\begin{tabular}{|c|c|}
\hline CASE & $H L W, P W R-S F, 1 \supset \supset \supset 0, G, G, C-O$ \\
\hline $\begin{array}{l}\text { DENSITY OF ACTINIDE } \\
\text { COMPOUNDS IN SOLUTION } \\
\text { (GM,CC, }\end{array}$ & $\begin{array}{c}\text { CRITI CAI RADIUS } \\
\text { (CM) }\end{array}$ \\
\hline 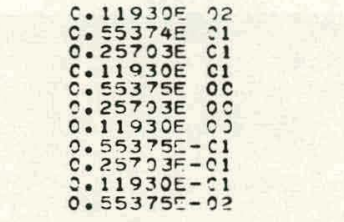 & 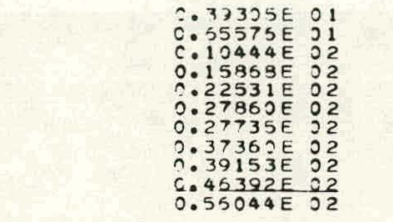 \\
\hline QITICA & $=21 \mathrm{KI}$ \\
\hline
\end{tabular}

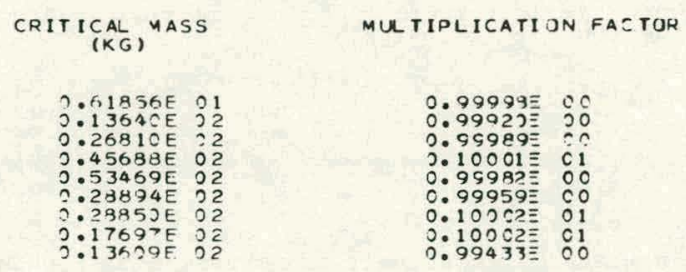

CRITICA (KG) $^{\text {MASS }}$

MULTIPLICATION FAETOR

$0.10023 \equiv 01$
CRITICR ${ }_{(K G)}$ "ASB

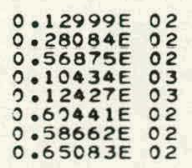

MINIMUM CRITICAL MASS IS C.12999E O2 KILOGRAMS

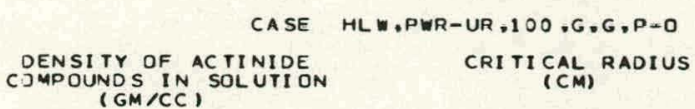

C. $11460 E$ OP

$0.11460 E$ O2

0.24690 E 11

0.53193300

C. $24690 E$ : 00

$0.53193 E-C_{1}$

MINIMUM CRI IICAL MASS IS C.15390E OZ KILOGRAMS

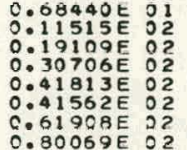

O.80069E KILOGRAM
0.31718 O 01

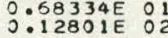

$0.20825 \mathrm{O}$ O

O. $27467 \mathrm{E}$

$0,23615 E$ E 02

$0.86235 E$ O 1

$0.55128 E$ OI

$$
\begin{aligned}
& \text { CRITICAL) }
\end{aligned}
$$

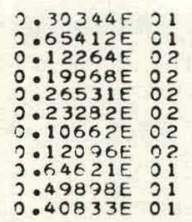

:09925E OC

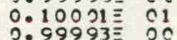

$\begin{array}{lll}0.99993 & 0 & 0 \\ 0.10033 & 01\end{array}$

0.080 .00

C. 101910101

$0.10405 \equiv$
$0.98425 \equiv$

MULTIPLICATI JN FAETOR

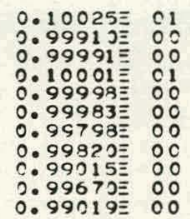

0.99670 O00

MULTIPLICATIOH FACTOR

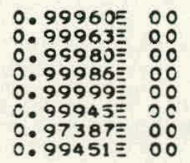

CRITICA MASS

(KG)

MULTIPLICATION FAETOR

$015390 \mathrm{O}$ O2

0.721711 O

$0.13898 E$ O 3

$016289 \mathrm{E}$
0.74254

$\hat{n}: 11301 E \mathrm{E}^{3}$

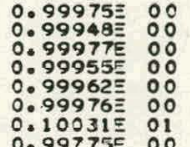




\begin{tabular}{|c|c|}
\hline CASE & $H L W, F W R-U R, 1000, G_{0} G_{0} P-0$ \\
\hline $\begin{array}{l}\text { OENSITY DF ACTINIDE } \\
\text { CUMPCUNDS IN SOLUTION } \\
\text { (CN,CC) }\end{array}$ & CRITI C CAL RADIUS \\
\hline 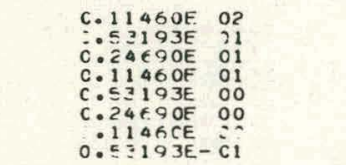 & 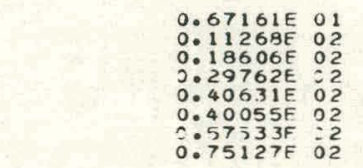 \\
\hline
\end{tabular}

MIN IMLM CRITICAL MASS IS 0.14543E O? KILOGRAMS

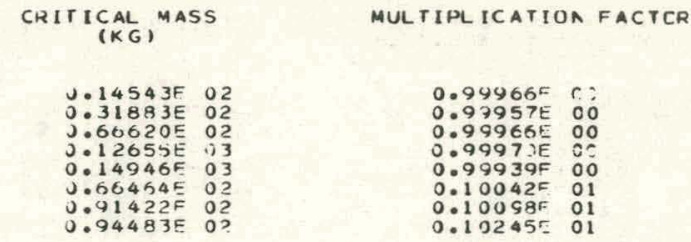

CRITICAL MASS

$(K G)$

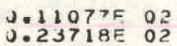

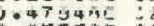
\begin{tabular}{lll}
$0.87773 E$ & 02 \\
\hline .112475 & 0 & 3
\end{tabular} $0.02576=05$ 30493502 0.91792582

$0.1146: O F$ O

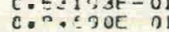

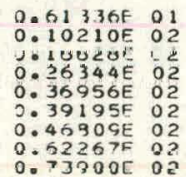

MIVIMUM CPITICAL MASS IS 0.11:PTE O2 KILOGRAMS

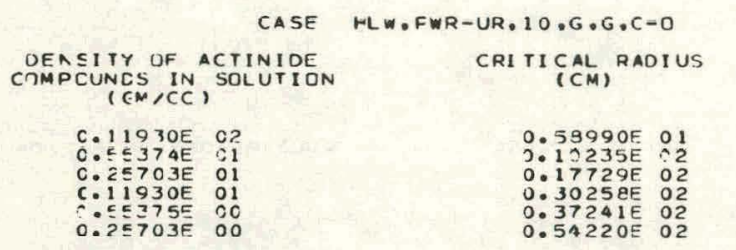

MINIMUM CRITICAL MASS IS $0.10258 E$ O? KILCGRAMS

\begin{tabular}{|c|c|}
\hline 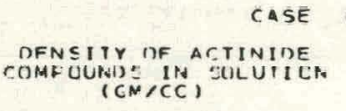 & $\begin{array}{l}\text { CRITICALL, RADIUS } \\
\text { ICNI }\end{array}$ \\
\hline 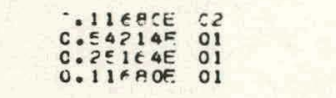 & 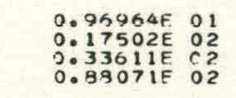 \\
\hline
\end{tabular}

MINIMUN CDITICAL MASS IS $20446: 4 E 02$ KILDGPAMS

\begin{tabular}{|c|c|}
\hline CASE & HEW,PWR-UR, $100, G, G, A-O$ \\
\hline $\begin{array}{l}\text { OENSITY OF ACIINIDE } \\
\text { COMPOUNOS IN, SOLUTION } \\
\text { COW CCC) }\end{array}$ & CRI TIC CAL ${ }_{(C M)}$ FAOIUS \\
\hline 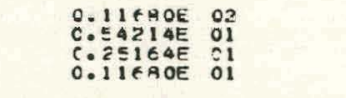 & 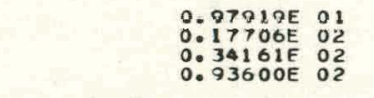 \\
\hline
\end{tabular}

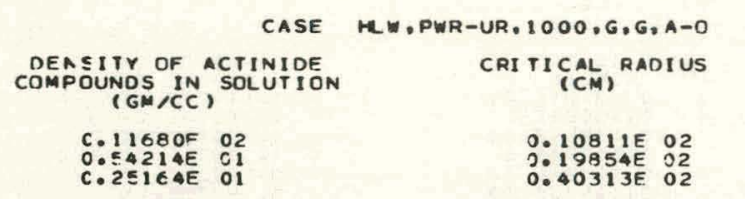

CRITICAL MASS

$0: 61815 E$ E2 $0.69059 E_{03}^{3}$
MULTIPLICATION FACTCR

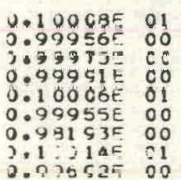

MUL TIPL ICATION FACTCA

$0.100 C B F 01$ 000 0.99935 S O.1 $0026 E$ C1
MULTIPLICATION FACTCR

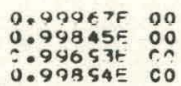




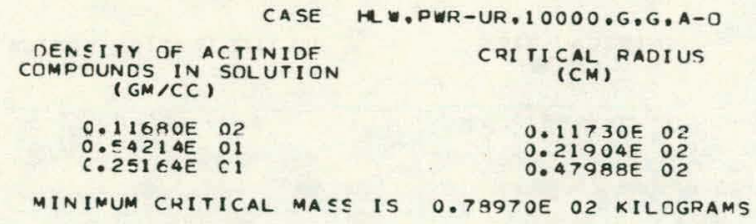

\begin{tabular}{|c|c|}
\hline CASE & $H L W, P W R-U R, 10, G, G, C-O$ \\
\hline $\begin{array}{l}\text { DENSITY OF ACTINIDF } \\
\text { COMPCUNDS IN SOLUTION } \\
(\mathrm{GM} / \mathrm{CC})\end{array}$ & $\begin{array}{l}\text { CRITICAL RADIUS } \\
\text { (CMM) }\end{array}$ \\
\hline
\end{tabular}
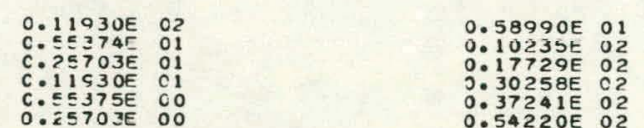

MINIMUM CPITICAL MASS IS 0.10258E 02 KILOGRAMS

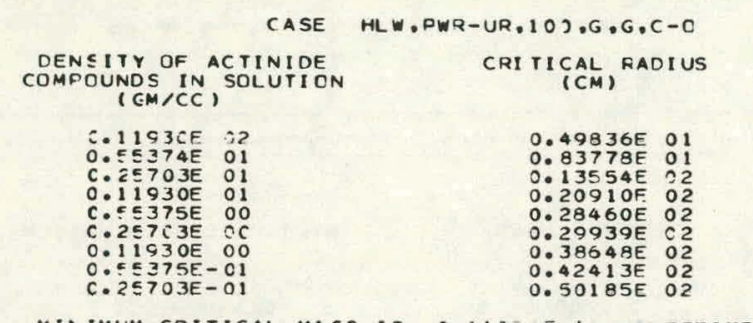

MINIMUM CRITICAL MASS IS O.61850E O1 KILOGRAMS

\begin{tabular}{|c|c|}
\hline CASE & HLW, FWR-UJR, $1000, G, G, C-D$ \\
\hline 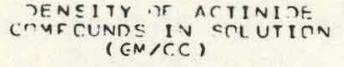 & $\begin{array}{r}\text { CRI TICAL FADIUS } \\
\text { (CU) }\end{array}$ \\
\hline 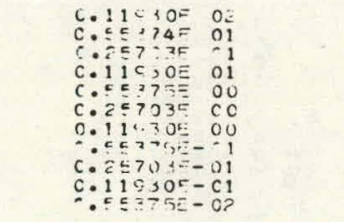 & 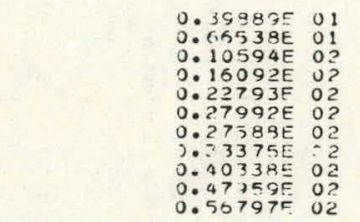 \\
\hline
\end{tabular}

WIAIVLN CPITICAL MASC IS 0.31713E O1 KILOGRAMS
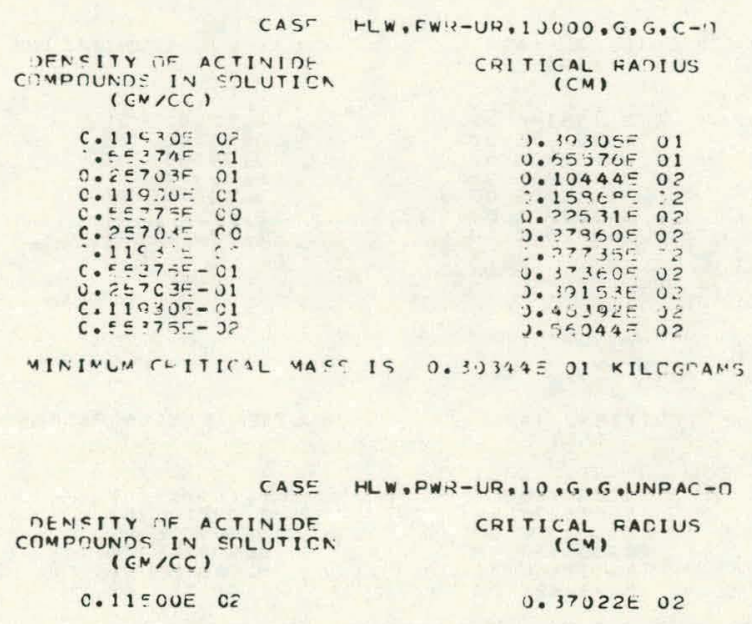

MINIMLN CHITICAL MASS IS $0.24444 E$ O4 KILOGRAMS

\begin{tabular}{|c|c|}
\hline $\begin{array}{c}\text { CRITICAL } \\
\text { (KG) } \\
\text { MASS }\end{array}$ & MULTIPL ICATIOA FACTCR \\
\hline $\begin{array}{l}0.78970 E \\
02 \\
\text { O:23867 } 03 \\
0.11549 E \text { O4 }\end{array}$ & 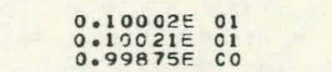 \\
\hline
\end{tabular}

CRITICAL MASS

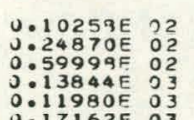

$\begin{array}{lll}0.11980 E & 03 \\ 0.17162 E & 03\end{array}$

CRITICAL MASS

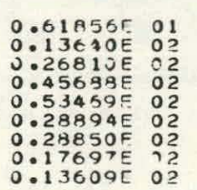

CRITICAL MASS

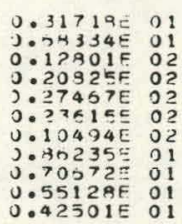

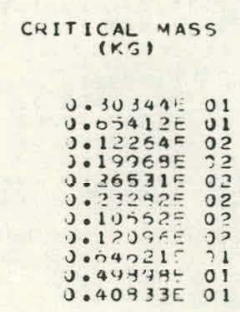

CRITICAL, MASS

$0.24444 E 24$
MULTIPLICATION FACTCR

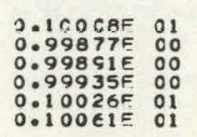

MULTIPL ICATION FACTCR

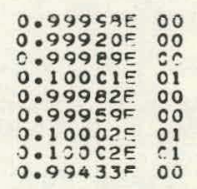

MULTIPL ICATION FACICR

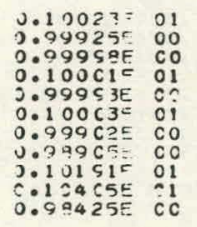

MULTIPL ICATIOA FACTCR

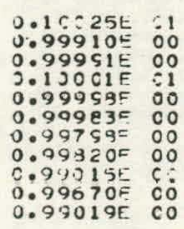

MULTIPLICATIOA FACTCR

ง.9 $985 E$ CC 


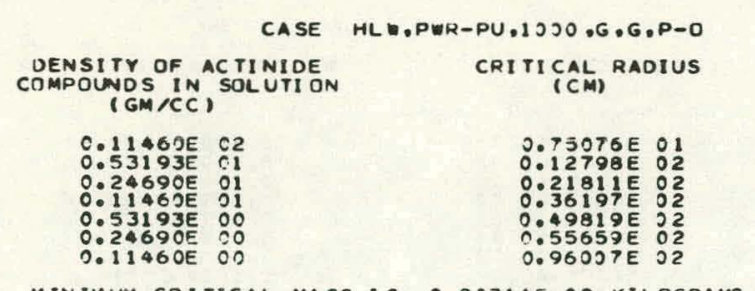

MINIMUM CRITICAL MASS IS $0.2 C 314 E$ O KILOGRAMS
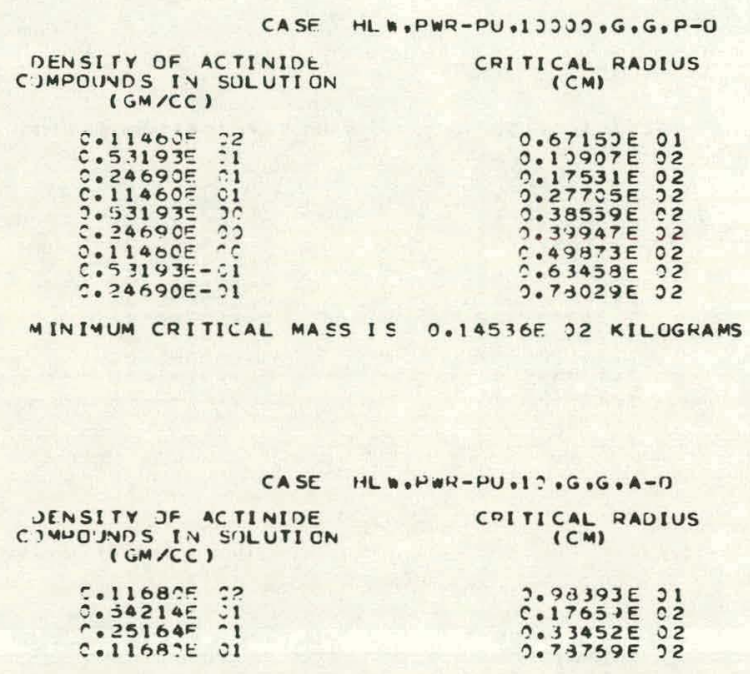

\begin{tabular}{|c|c|}
\hline CASE & $H L W, P W R-P U, 1 J 0, G, G, A-0$ \\
\hline $\begin{array}{c}\text { DENSITY OF AC TINIDE } \\
\text { CJMPOUNDS IN SOLUTION } \\
\text { (GM ICC) }\end{array}$ & $\begin{array}{c}\text { CRITICAL RADIUS } \\
\text { (CM) }\end{array}$ \\
\hline 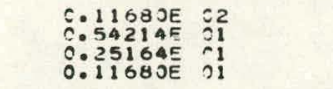 & 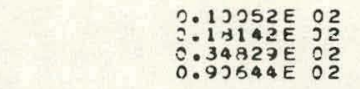 \\
\hline
\end{tabular}

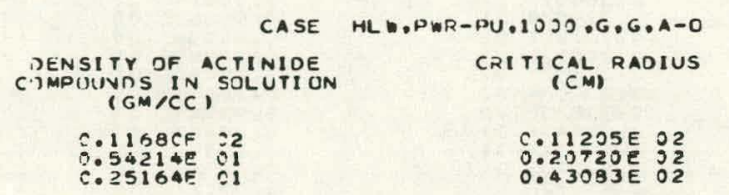

AINIMUM CRITICAL MASS IS 0.58833 E O2 KILOGRAMS

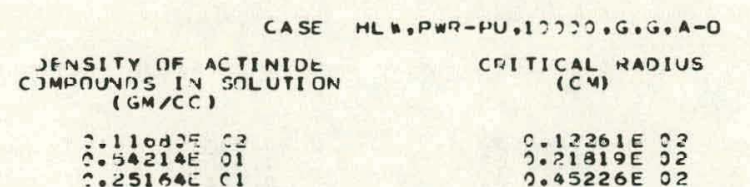

AINIMUM CRITICAL MASS IS 2.PCITAF J2 KILOGRAMS

AINIMUM CRITICAL MASS IS 2.46606 E 32 KILIJGRAMS

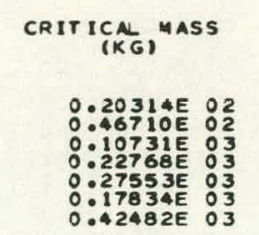

MUE TIPLICATION FAETOR

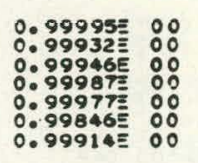

CRITICA MASS

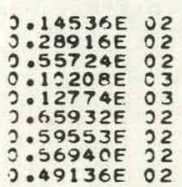

MULTIPLICATIJN FAETIJR

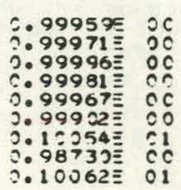
CRITICA MASS
$9.466065 ; 2$
;. 394611 E 03

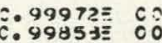

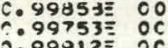

\section{CRITICA ${ }_{(K G)}^{\text {NASS }}$ \\ O.49688E O2 \\ $\begin{array}{lll}0.13561 E & 03 \\ 0.44538 E & 3 & 3 \\ 0.3644 C E & 04\end{array}$}

$0.99972 \equiv$

0.99724 : 00
CRITICN (KG) MASS $^{-}$
$0.68833 E$ ?2
$0.84296 E^{0} 3$

MUETIPLICATION FACTOR

$0.99993 E$
909609
309962

CRITICR WASS

MUTIPLICATION FAETOR

O. PO174E O2 O. 097509 E 33
9:99979E :6 T. 9940954 CC 


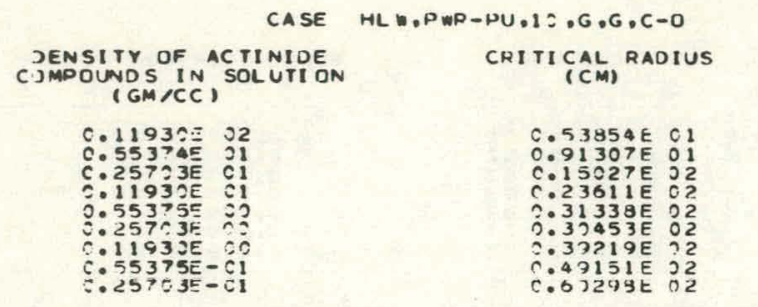

MINIMUM CRITICAL MASS IS $0.78056 E$ OI KILOGRAMS

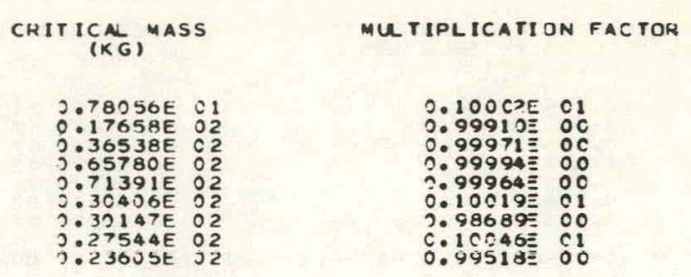

CRITICAL MASS

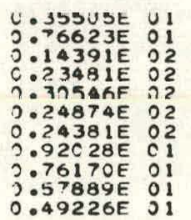

MU. TIPLICATION FACTOR

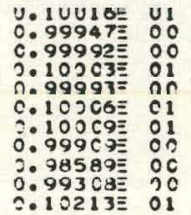

MINIMUM CRITICAL MASS IS $0.35505 E$ गI KILOGRAMS
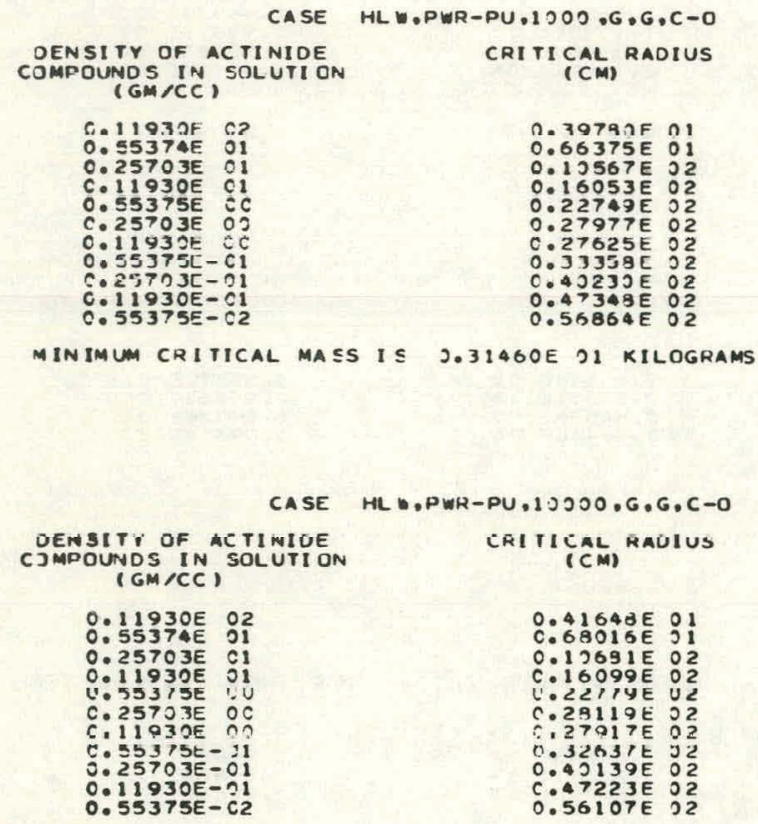

MINIMUM CRITICAL MASS IS $\$ 36101 E$ OI KILOGRAMS

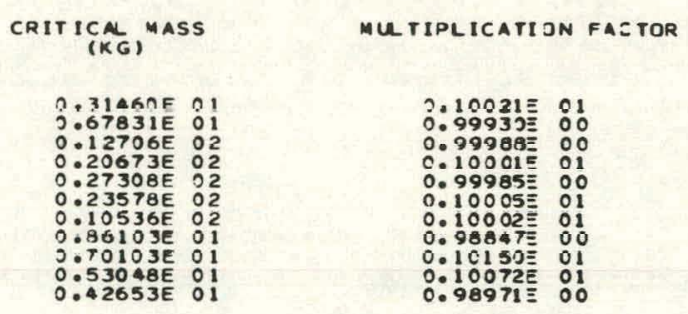

CKIIILA IKG) NASS

mú TIRLICATIUN FACTUM

$\because 36101 E$ O1

$0.1312 C \mathrm{CE}$

$0.20853 \mathrm{E}$ O2

U. . S I I U UL

$0.23938 E$ OL
$0.12873 E$ O2
$0.128043 E$

$0.06643 \mathrm{~F}$

$3.69631 E$
$0.52629 E$

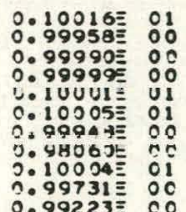

CASE HL O.PER-PU.10.G.G.UNPAC-O

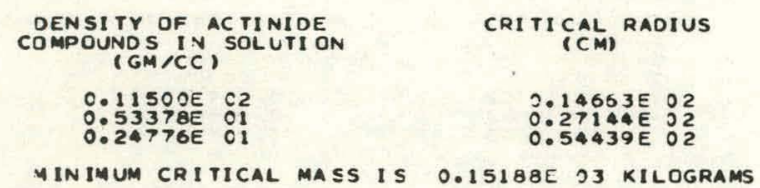

CRITICAL MASS

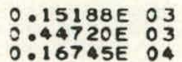

MULTIPLICATION FAETOR

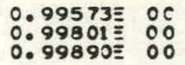




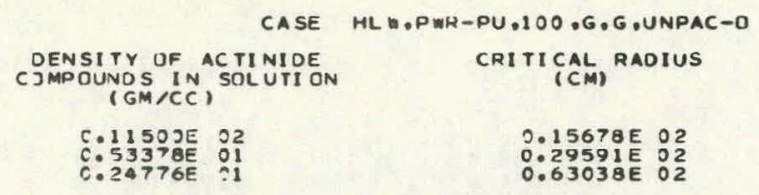

IN IMUM CRITICAL MASS IS 0.18564E O3 KILOGRAMS

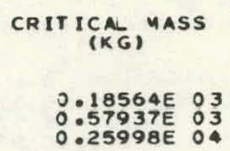

\begin{tabular}{|c|c|}
\hline CASE & HEW,FWR-PP, $10000, G_{0} G_{0} U$ U- \\
\hline $\begin{array}{l}\text { RFASITY ITF ACTINIDE } \\
\text { COMPOUNOS IN SOLUTION } \\
\text { (GN,CC) }\end{array}$ & CRITICAL RADIUS \\
\hline 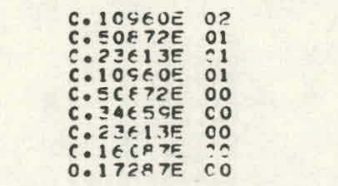 & 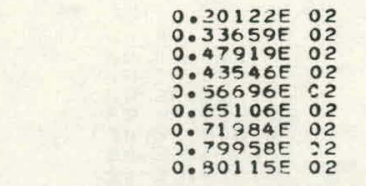 \\
\hline
\end{tabular}

MINIMLM CRITICAL MASS IS $0.34450 E$ O3 KILOGRAMS
VINIMUM CRITICAL MASS IS 0.15140E O3 KILOGRAMS

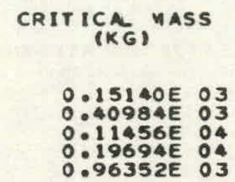




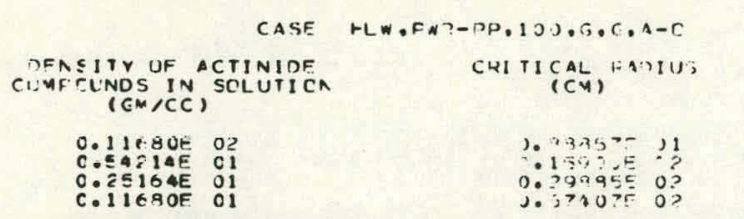

MIAINUM CRITICAL MASS IS $0.34326 E$ OZ KILOEIANS

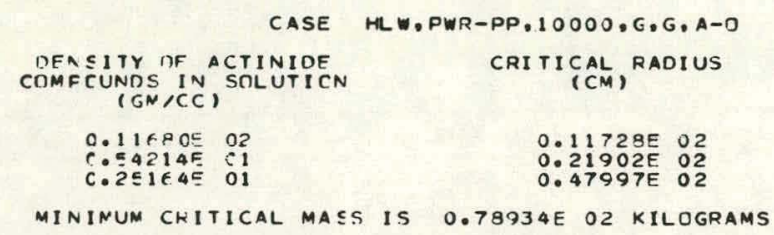

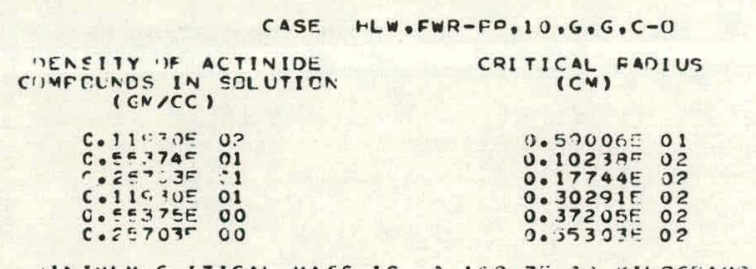

CASE HLW.FW.Z-PD, 100.G.G.C-C

\begin{tabular}{|c|c|}
\hline 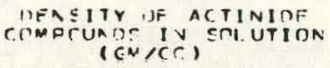 & $\begin{array}{r}\text { CHITICAL FADIUS } \\
\text { (CM) }\end{array}$ \\
\hline 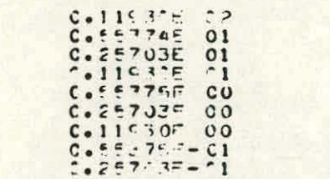 & 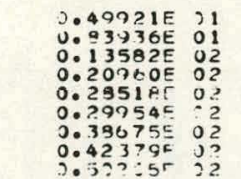 \\
\hline
\end{tabular}

WIAINLU CHITICAL MASS IS 0.j2172E OI KILCGRAMS

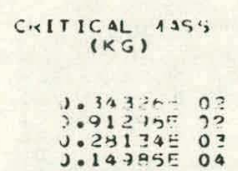

CRITICAL MASS

$0.38207 \mathrm{E}$ O2

$0.10256 E$ O3

$0.32490 E$ OS
$0.20603 E$ OL

CRITICAL, MASS

$0.78934 E 02$ J.23860E OJ

CRITICAL MASS

3) 102670 O2

J. $60147 E$ O

0.13890E 03

J.11946E O3

\begin{tabular}{|c|c|}
\hline $\begin{array}{l}\text { OENSITY OF ACTIPAIDE } \\
\text { CIJMPOUNDS IN SOLUTICN } \\
\text { (GM,CE) }\end{array}$ & CRI IICAL (CM) $^{(C A D I U S}$ \\
\hline 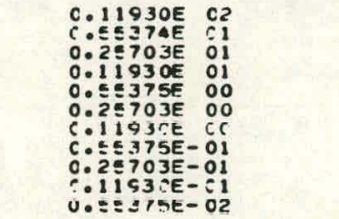 & 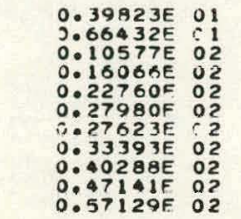 \\
\hline
\end{tabular}

INIMLN C-ITICAL MACS IS O.1:?.,?E: 2 KILOEGIAMS

ASE MW.FWR-PP, $1000, G, G, C-0$
CRITICAL, MASS

,.6517.?5 J1

$0.13717 E$
0.25974

O. 4501 1EE

J.53799E O

J.17555E O?
ว. $38939 F$

CRITICAL MASS

U. 31560E OI

J. $08006 E$ OI

$0.2-723 E$ O

O. $27349 \mathrm{~F}$ O2

$0.23585 E$ O2

$0.86376 E$

$3.70406 E$ O

J. $\$ 2353 E$ OI
MULTIPLICATIOA EACTCR

$3.100 C 5:-01$
$3.998 E 3 F$

$0.99745 F$ CC
MULTIPL ICATION FACTCR

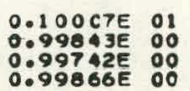

MULTIPLICATION FACTCR

$0.10000 E$ CI

$0.10021 E$ OL
MULTIPL ICATIUA FACTCR

0.100 CBE 01

$0.99875 E$ OO

0.99928500

$0.1004 B E$ CI

MULTIPLICATIOA FACTCR

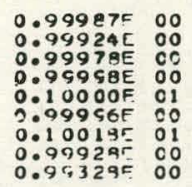

MULTIPL ICATION FACTCR

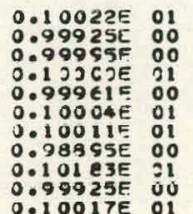




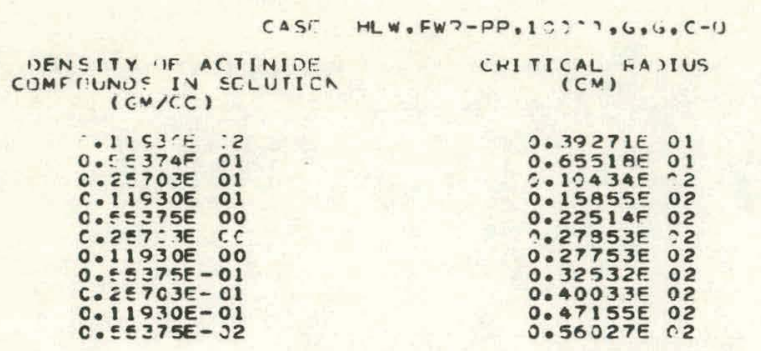

MINIMUM CRITICAL MASS IS 0.30267E OI KILOGRAMS

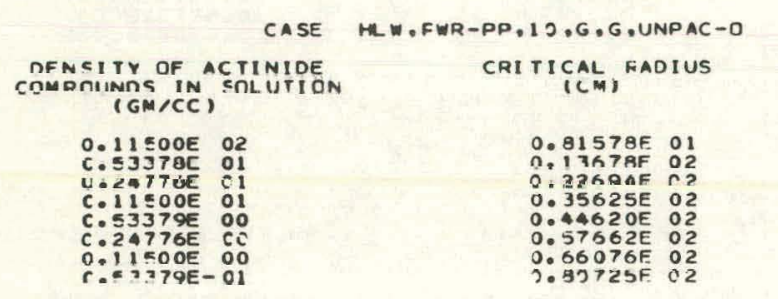

MINIMUM CRITICAL MASS IS 0,26153E O2 KILOGRAMS

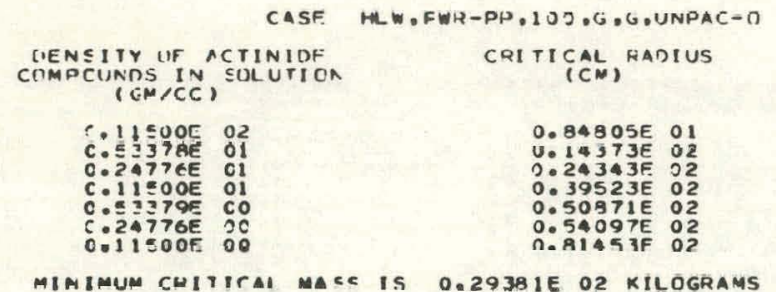

MINIMUM CWITITAI MASe IS 0.29381E 02 KILOGRAMS
CRITICAL MASS

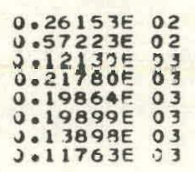

J.1 $1763 \mathrm{E}$ : 33
MULTIPL ICATIOA FACTTO

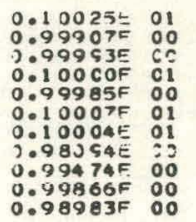

\begin{abstract}
MINIMUM CRITICAL MA SS IS O,
\end{abstract}




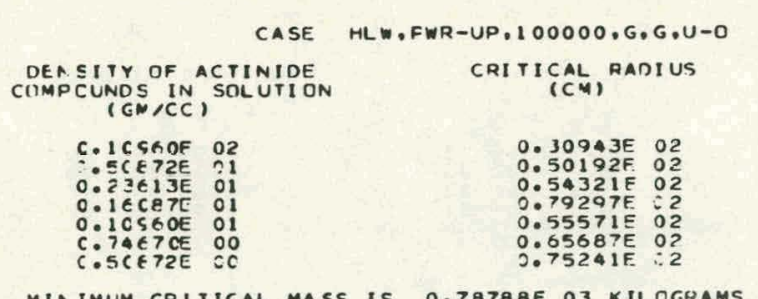

MIAIMUM CRITICAL MASS IS O.79788E O3 KILOGRAMS

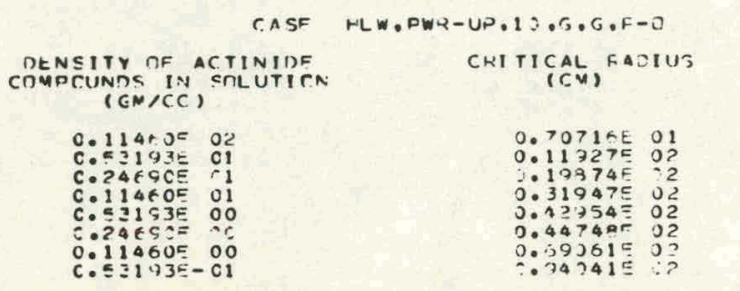

MINIMUM CRITICAL MASS IS 0.1537EE 02 KILCGRAMS
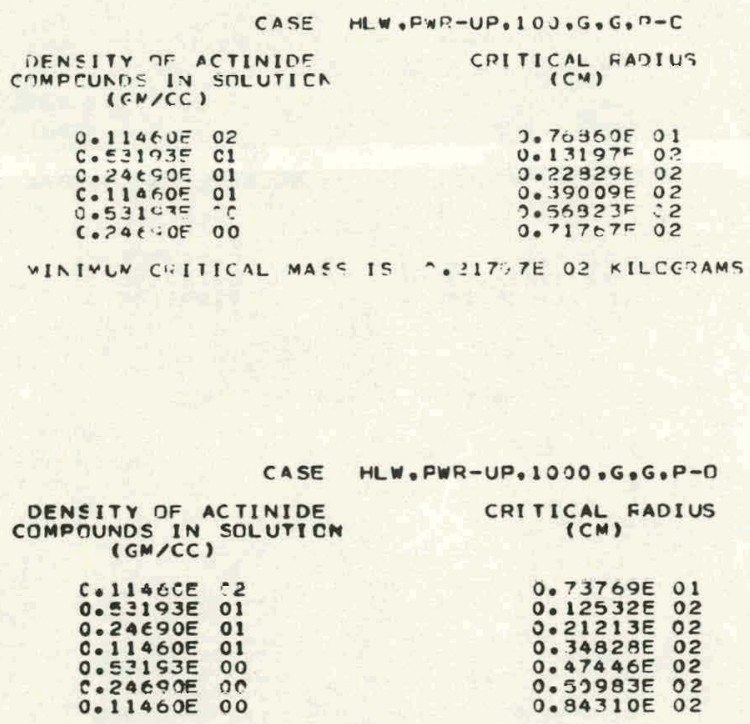

MINIMUM CRITICAL MASS IS 0.19272E 02 KILCGRAMS

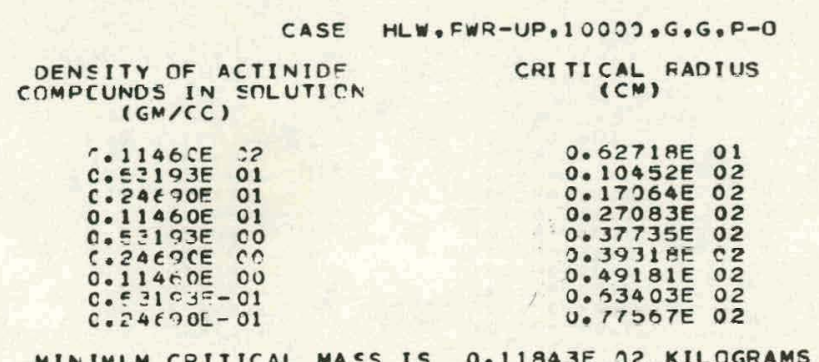

MINIMLM CPITICAL MASS IS $0.11843 E$ O2 KILOGRAMS

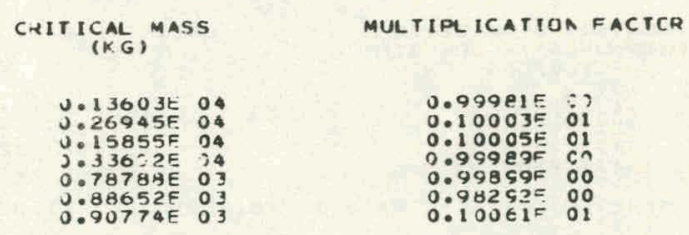

CRITICAL, MASS

J.15G,765 0 ?

J.37808E OS?

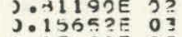

$0.17050=03$

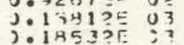

MULTIPLICATIDN FACTCR

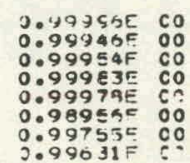

CRITICAL) MASES

). $21797 F \quad 02$

$0.51213 E$ J
$0.12305 E$ O?

J.2 $12305 \mathrm{EE}$ O ?

O.408Н2E O3

MULTIPLICATION FACTCR

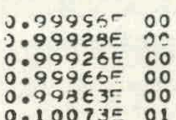

0.99673 00

CRITICAL, MASS

$0.19272 E \quad 02$

$0.43852 E$ O2

ว.9B734E O2

$0.20280 E$

O.1370EE OJ

0.1370EE OJ

$0.10000 E$ OI

$0.99938 \mathrm{E}$ \%०

:०99949E 00

$0.99910 E$
0.905120

0.10007 OI

CRIT ICAL, MASS

MULTIPL ICATIOA FACTCR
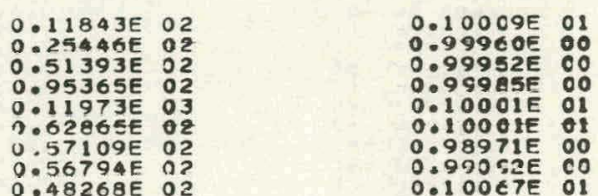


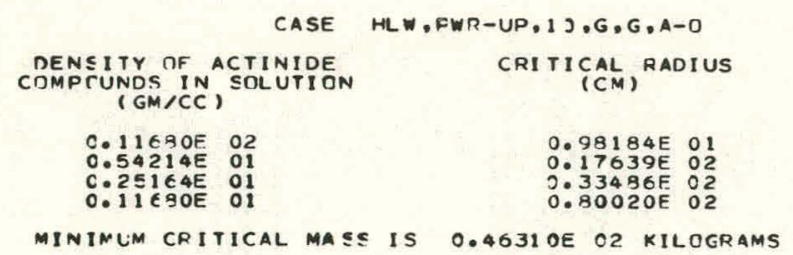

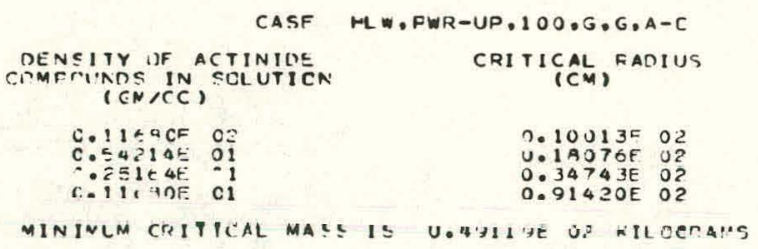

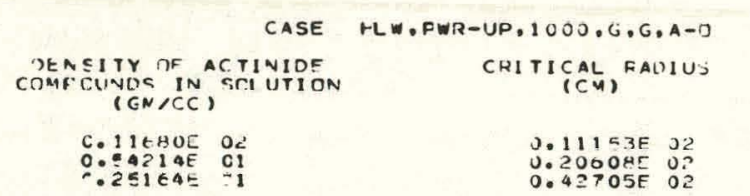

MIA IMLM CHITICAL MASS IS $0.07992 F$ O2 KILOGDAMS
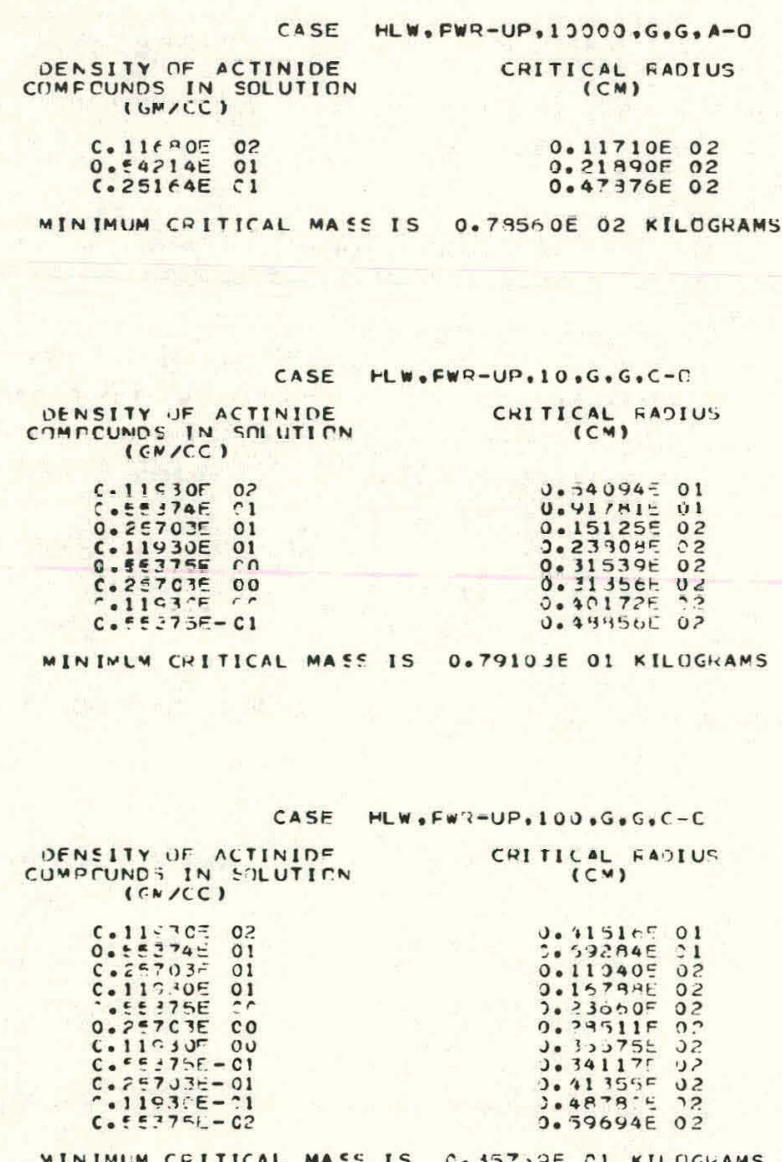

MINIMLM CRITICAL MASS IS O.7910JE OI KILOGKAMS

WINIMUM CFITICAL MASC IS C. 357, BE TI KILOGIEAMS

$$
\text { CRITICAL, MASS }
$$

$0.46310 E \quad 02$ $0.12463 E$ OS O.35580E $: 33$

CRITICAL MASS

$0.43119 F \quad 02$ $0.13412 E$ O $\begin{array}{ll}0.44203 E & 03 \\ 0.373 \text { SAE } & 04\end{array}$

CRITICAL MASS

T.STतH? O? $\begin{array}{lll}0.198765 & 03 \\ 0.92097 & 03\end{array}$

CRITICAL, MASS $\begin{array}{lll}0.72560 & 02 \\ 0.23822 & 03 \\ 0.11568 E & 04\end{array}$

CRITICAL MASS

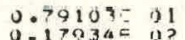

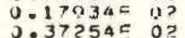

J.07439E OS

$0.72772 \mathrm{~F} \quad 02$

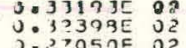

CIITICAL MASS

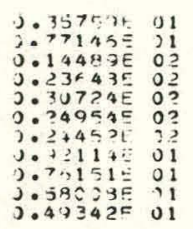

MULTIPL ICATION FACTCR

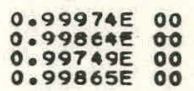

MULTIPL ICATIOA FACTCR

$0.93979 F \quad 00$ $0.99714 E$ OD
MULTIPLICATIOA FACTCR

$0.99977 E$ OO

0.1999 CaE OO

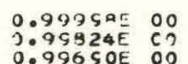




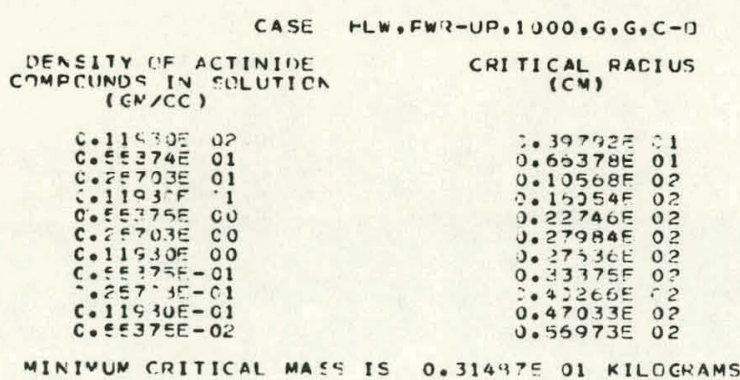

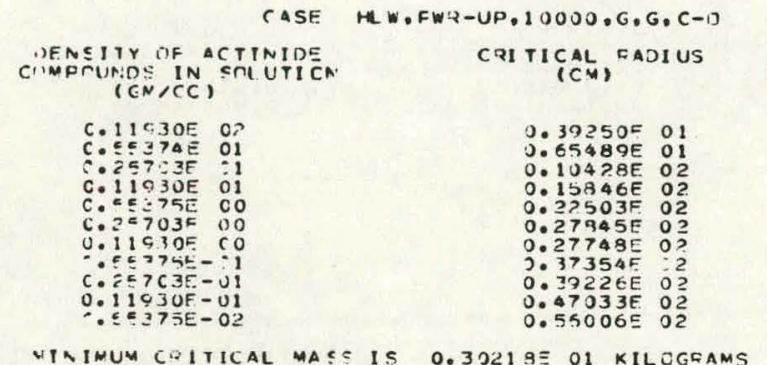

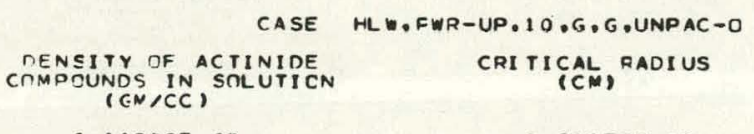

C.: 115000 O2

$0.21175 E \quad 02$

MINIMUM CRITICAL MASS IS 0.45739E O3 KILOGRAMS

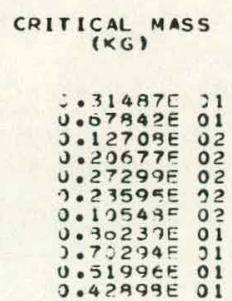

CRITICAL. MASS

J. $30219=01$

3.0515250

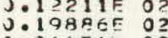

j. 20434 t 22

0.33545 . 02

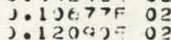

J.1204)= 02

J. $34995 E$ OI

J.51997E OI

CRITICAL MASS

$0.45739 E$
O. 3
O.17002E 04

$0.10001 E$ OI
j.9978OE CO

$0.1002 j=c 1$

U.99927E CO

$0.100 \mathrm{C} 1 \mathrm{~F}$ 01

ग.999 हBF

$0.100 C 3=$

0.999595

0.9975950

0.980 EFF 00

\section{CASE MLW,FWR-UP,100,G,G,UNFAC-O DENSITY FF ACTINIDE
CIJMF CUNDS IN STLUTION
(GM/CC) CRITI CAL FADIUS $\begin{array}{ll}\text { C. } 11 \leq 00 E & 02 \\ \text { C. } 5 \geq 378 F \text { O1 }\end{array}$ $0.22517 E$ O2
$0.46424 E$ O2 MINIMLM CRITICAL MASS IS $0.54994 E$ O3 KILOGRAMS}

\begin{tabular}{|c|c|}
\hline $\begin{array}{c}\text { CRITICAL MASS } \\
\text { (KG) }\end{array}$ & MULTIPLICATIOA FACTCR \\
\hline 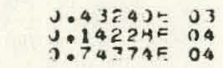 & $\begin{array}{l}\text { :0сवEगत c0 } \\
0.99052 E \text { co } \\
0.99950 E \text { có }\end{array}$ \\
\hline
\end{tabular}

CRITICAL) MASS
(KG)
$0.54994 E$ O3
$0.22372 E$ O4

CRITICAL MASS

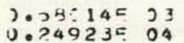

?.22921E i2
$0.48120 E$ O2

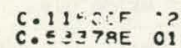

MINIMUM CRITICAL MASS IS O.53214E C3 KILCGRAMS

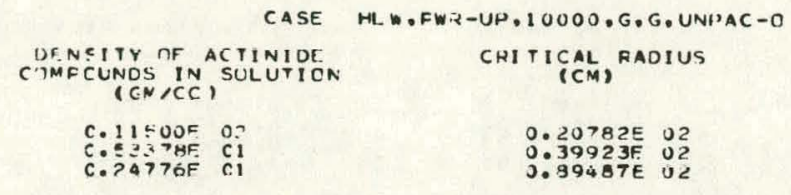

MINIMUN CAITICAL MASS IS O.43240E C3 KILOGRAMS 


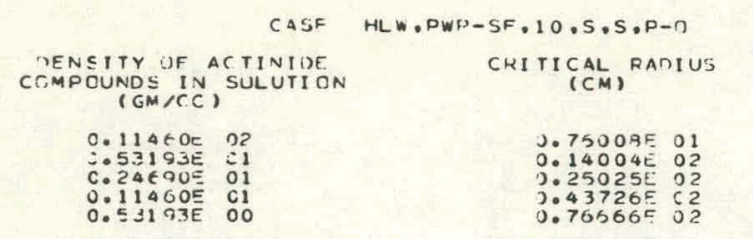

MINIMLM CEITICAL MASS IS 2.21:32E ?? KILOGIZAS

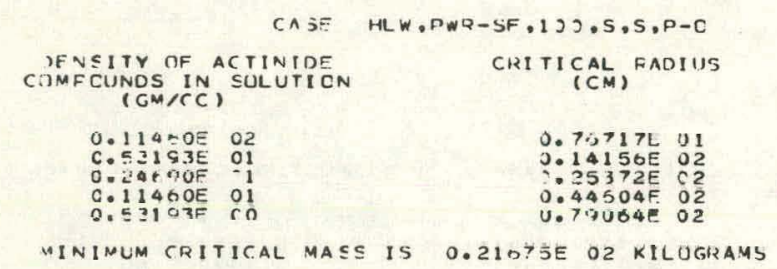

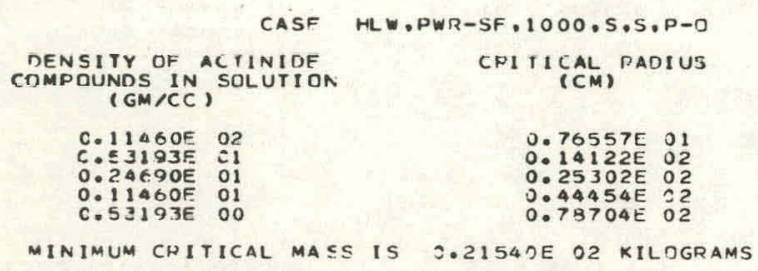

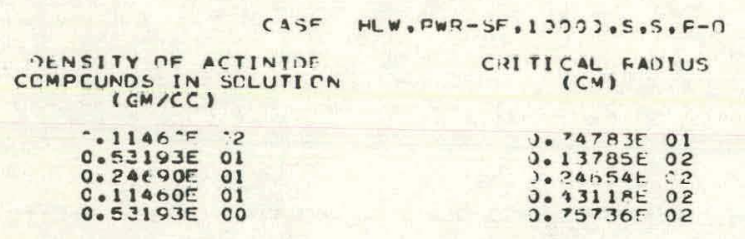

MINIMUM CRITICAL MACS IS O.PJOPJE O? KILOGRAMS

\begin{tabular}{|c|c|}
\hline$r \Delta S F$ & $H W, P W R-S F, 10, S, S, A-1]$ \\
\hline $\begin{array}{l}\text { UFNSITY DF ACTINIDE } \\
\text { COMPOUNOS IN, SULUTICN } \\
\text { (GM,CC) }\end{array}$ & CRI TICAL RADIUS \\
\hline 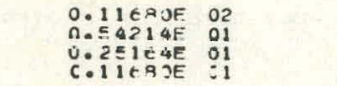 & 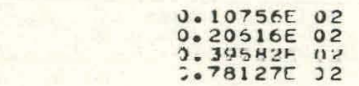 \\
\hline
\end{tabular}

MINIMUM CRITICAL MASS IS O.6OS9OE O2 KILOGRAMS

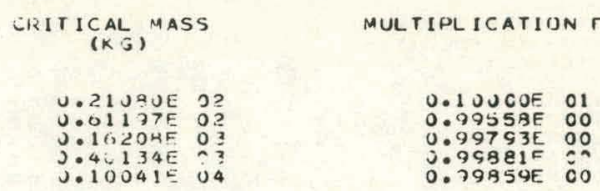

CRITICAL, MASS
(KG)

U. $213 T 5 E$ O? 0.63204E O2 J.16932E 33
J.4 $2001 \mathrm{E}$ U3
J.11013E 24 CHITICAL MASS

$0.21540 E 02$ $0.02761 E$ O2 $\begin{array}{ll}0.42174 \mathrm{~F} & 03 \\ 0.10863 E & 04\end{array}$
MULTIDLICATION FACTCR

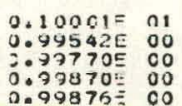

MULTIPLICATION FACTCR

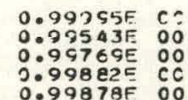

CRIT ICAL, MASS

U.20077F 02 $38365 E$ O3 0.381 B 0 BE
CRIT ICAL MASS

O.O. BO.2E 22 $\begin{array}{ll}0.65370 \mathrm{~L} & 03 \\ 0.23332 \mathrm{~F} & j 4\end{array}$
MULTIPLICATION FACTEH

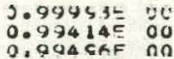
O. OOA GRF RO

\subsection{0 c? 01 $0.97541 E$
$? .99781=$ ? 0.99870F C. \\ MULTIPLICATIOAN FACTCR}



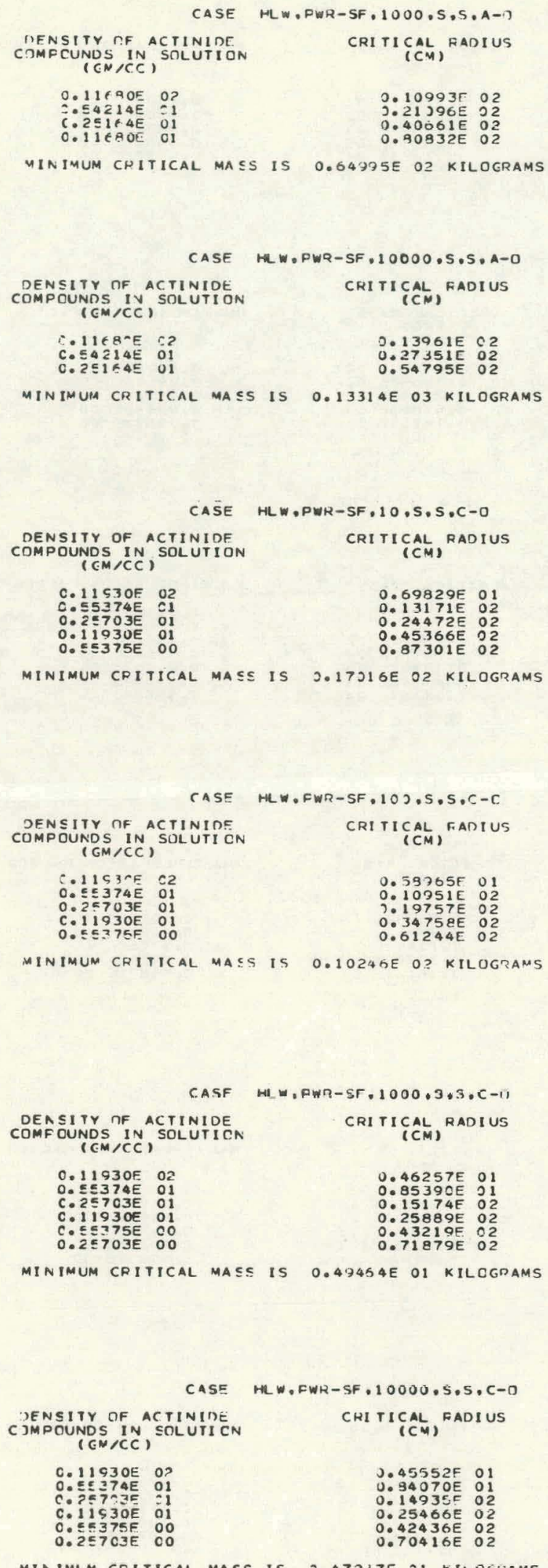

MULTIPL ICATIOA FACTCR

$0.99998 E$ OO
$0.99405 E$ OC $0.99405 E$ OC $0.64995 E 02$ $\checkmark .70862503$ $0.9956 O E$ OO

MINIMUM CRITICAL MASS IS 0.10246E O? KILOGRAMS

CKITICAL MASS

$0.13314 \mathrm{E} \mathrm{O3}$ $\begin{array}{lll}0.46467 E & 03 \\ 0.17343 E & 04\end{array}$

CRITICAL MASS

U.17016E O? U. $53004 \mathrm{E}$ O? j.46659E 03 J. $46659 \mathrm{E}$
$\mathrm{U} .15434 \mathrm{E}$ CRITICAL MASS

U. $10276 E$ O? J.30458E O? J.830 3CE D2 U. 32 S2E 03

CRITICAL) MASS

$0.49464 E$ OI J.14442E $\partial ?$ $0.37618 E$ O2 U.86711E O2 U.18726E 03

MINIMUM CRITICAL MASS IS 0.4945 4E O1 KILCGDAMS 

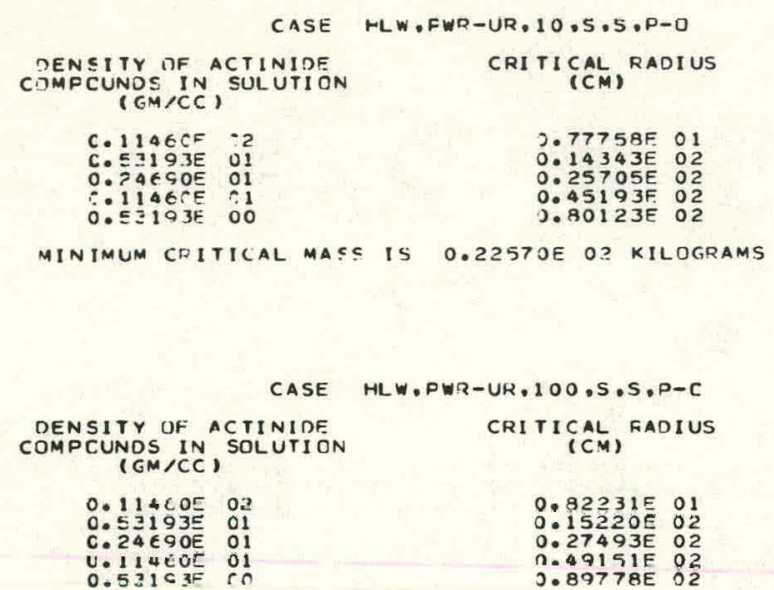

MINIMUM CFITICAL MASS IS $0.26693 E$ O2 KILOERAMS

\section{CKITICAL, MASS
(KG) \\ 0.22573 F 22 \\ U. 65742 E 02 \\ $\begin{array}{lll}0.175675 & 03 \\ 0.44312 E & 03\end{array}$ \\ $0.44312 E$
J.11 $1461 E$}

CRITICAL, MASS

$0.2,3693 \mathrm{E} 02$

$0.7355=5$ OS

$0.21492 E$ O3

$\begin{array}{lll}0.57003 E & 03 \\ 0.16124 E & 04\end{array}$
MULTIPLICATIOA FACTCR

$0.10001 E$ OI
$0.99540 F$. 00 $0.99540 F$ OO
0.99767 OI $0.99854 E$ CO
0.9988 OSE

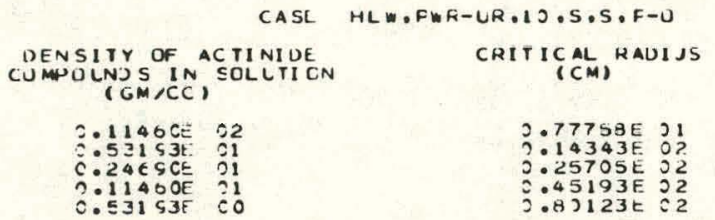

MINIMUM CRITICAL MASS IS 0.22570 J 22 KILOGRAMS

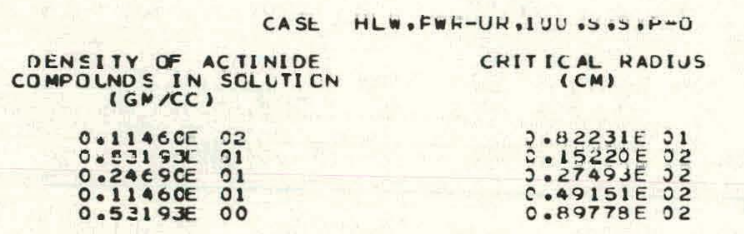

MINIMUM CRITICAL MASS IS C.20093E J2 KILOGRAMS

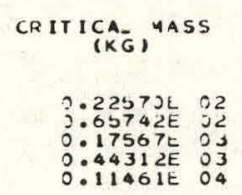

CR ITICA ${ }_{(K \bar{G})}^{\text {NASS }}$

$0.260 Y 3 E 02$

$0.21492 \mathrm{~L}$ OJ

O. $017003 \mathrm{E}$ O3
MULTIPL ICATION FACTCR

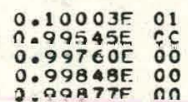
$0.99760 C$ OO O. $99848 E$ O OO

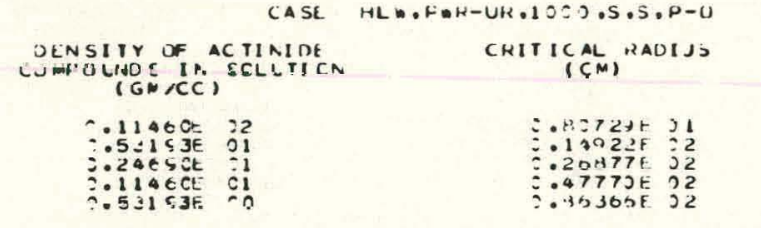

MLIIMLM CRITICAL MAOS IS 9.252 ITE 22 KIL JUHAMS

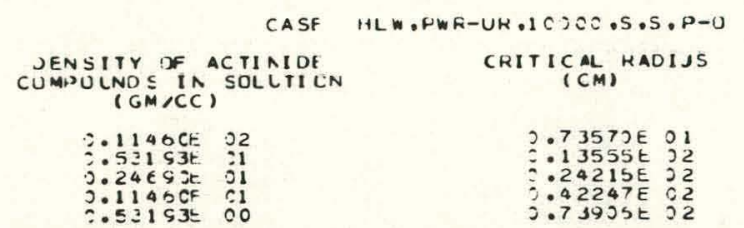

MINIMUM CRITICAL MASS IS C.19116E J2 KILIGRAMS

\begin{tabular}{|c|c|}
\hline CRIIICA ${ }_{(K G)}$ MASS & MUETIPIICATIOA FACTOR \\
\hline 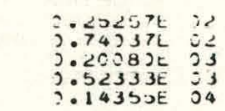 & 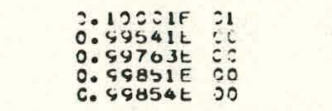 \\
\hline
\end{tabular}

CKITICA- ${ }_{(K G)}^{\text {AASS }}$

MUA TIPLICAIICA FACTOF

3.1911 UE 22

3146005

$0.36198 E$
03
$0.89952 t$ 3

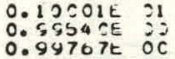

C. $99854 E$ CU
MUE TIPLICATION FACTOR

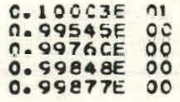




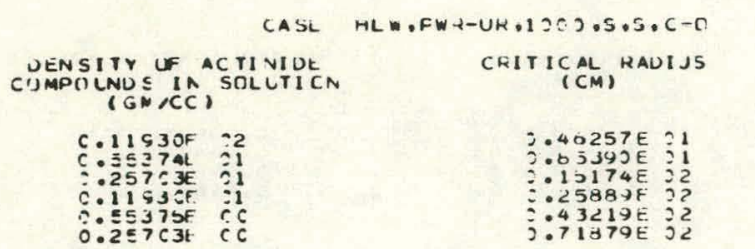

MIVIMUN CRITICAL MASS IS $2.49464 E 21$ KILOGHAMS

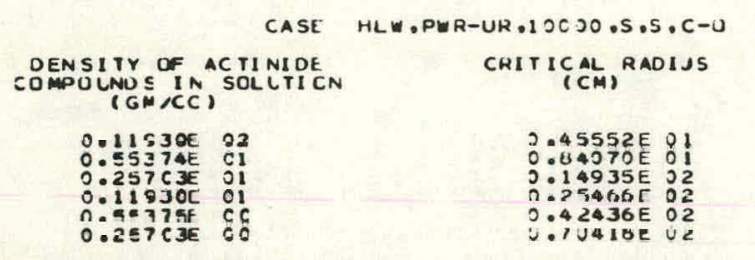

MINIMLM CRITICAL MASS IS C.47237E OI KILOGFAMS

$$
\begin{aligned}
& \text { CRITICA- MASS } \\
& \because .094042 \quad 31 \\
& \begin{array}{l}
39404 L \quad ? 1 \\
314442 t \geqslant 2
\end{array} \\
& \text { j:37613E } \\
& 3.86711 \text { t } 32 \\
& \text { J.18726= JS }
\end{aligned}
$$

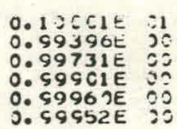

CRITICA- WASS

$0.47237 E$ O

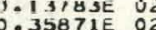
$0.35871 E$ O2
$0.82537 E_{0}$ ग.17726E US

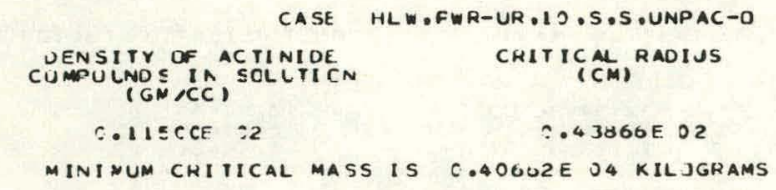

\author{
CRITICA-, ${ }_{(K A)}^{\text {MASS }}$ \\ $2.40602 E \quad 04$ \\ MULTIPLICATIOA FACTOR \\ $0.59997 E$ TE
}
C.ITICA- $(K)^{\text {MASS }}$

\begin{tabular}{|c|c|}
\hline $\begin{array}{l}\text { UENSITY OF ACTINIUF } \\
\text { CUMPOLNOS IN SOLLTICN } \\
\text { IGN, ICC, }\end{array}$ & CKITICAL RAOIJS \\
\hline$\therefore .11 \leqslant C S F \quad: 2$ & $=.42344 E C 2$ \\
\hline
\end{tabular}
$3.44273 E \quad 24$

$=.45129 \mathrm{~F} .2$

MINIMLM CRI IICAL MASS IS $: 044273$ E 04 KIL IGKAMS

\footnotetext{
CASE HLWOPWK-UK,I JIS.S.S.UNPAC-U

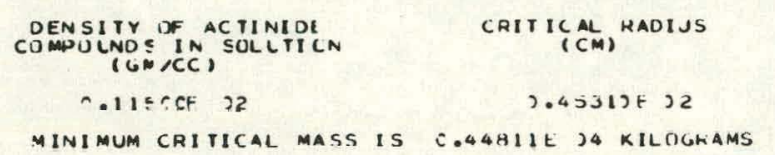

$$
\begin{aligned}
& \text { CRITICA- HASS } \\
& \text { (KG) } \\
& \text {.4481LE DH }
\end{aligned}
$$

CASE HLW FWH-UH. 1 JO 20.5 .5 . JNPAC-O

CASE HEW.PWR-PU. $100000.5 .5 . U-0$

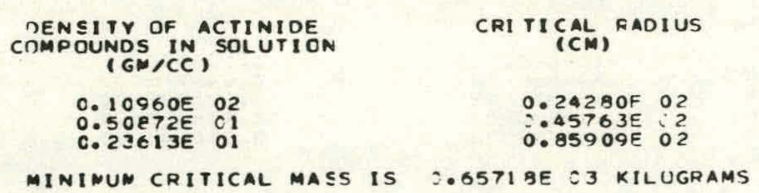

MINIMUN CRITICAL MASS IS 2.0571 SE 03 KILUGRAMS

$$
\begin{aligned}
& \text { CRITICA- MASS } \\
& \text { MKG) } \\
& 0.36574 E \text { OUTIPLICATION FACTOR }
\end{aligned}
$$

MULIHLICATIOA FACTOR

O.1OCOCE OI

MULTIHLICATICA FACTCR

$3.50254 t 2 r$ 


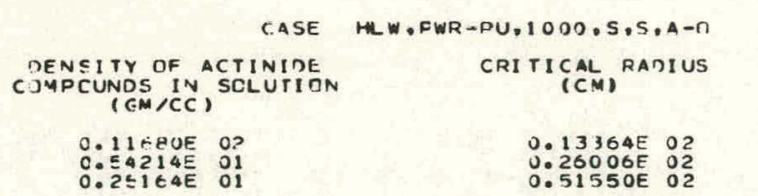

MIN:INUM CPITICAL MASS IS 0.11679 O3 KILDGRAMS

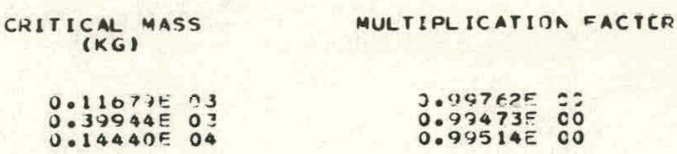
O.99762E $=2$
$0.93473 E$ CO
$0.99514 E$ CO

MULTIPLICATIOA FACTER

CRITICAL MASS

1733450 $\begin{array}{lll}0.55055 E & 03 \\ 0.18033 E & 04\end{array}$ $0.15215 \mathrm{E}$
02
$0.28942 \mathrm{E}$

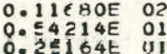
MINIMUM CRITICAL MASS IS O.1P234E O3 KILOGRAMS
Crat ICALL, MASS

U.130;DE 02 $3.3,5,250$

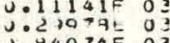
$0.39146 E$ O2

MINIMUM CNITICAL MASS IS O.13U.JOE O? KILIJGAMS T,, 179150

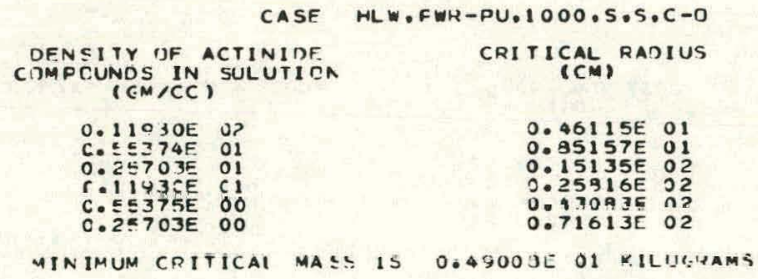

CASE HWW. FWR-PU.10000.S.S.C-0 DENEITY CIF ACIINIUE COMPCUNDS IN SOLUTION

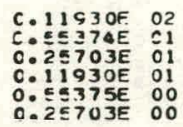
$0.49955 F$. 11 0.15711 O 02 $0.43516 E$ OO

MINIMUM CRITICAL MASS IS $0.62299 E$ O1 KILOGRAMS
CRITICAL, MASS

$0.55999 \mathrm{~F}$ O $0.16379 \mathrm{O}^{\circ}$ OI $0.42840 E$ OL

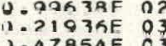
O.. 2711 OE US $U$ US

MINIMUM CUIUICAL MASS IS $0.55999 \mathrm{E}$ OI KILOGRAMS

\section{CKITICAL, MASS

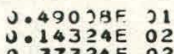 O.

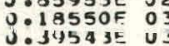

CRITICAL MASS

0.62239501 $0.169970^{02}$ O०:4175EE 02 $0.19114 \mathrm{O}_{3}$ S. $39616 \mathrm{~L}^{\circ}$ MULTIPL ICATIOA FACTCR $0.98329 F$ Zी $0.99428 \mathrm{COE}$

MULTIOL IS ATIOAA FACICR ว.ग 313500 .099783E CA

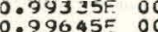

MULTIPL ICATIOA FACTCR 0.10062501 $0.99733 E$ CO O.99Y COE OO $0.99395 E$ OO
MULTIPLICATIOA FACTCR

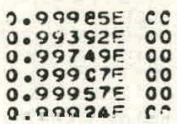

MUUTIPL ICATIOA FACTCR

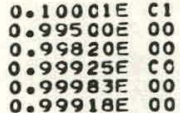




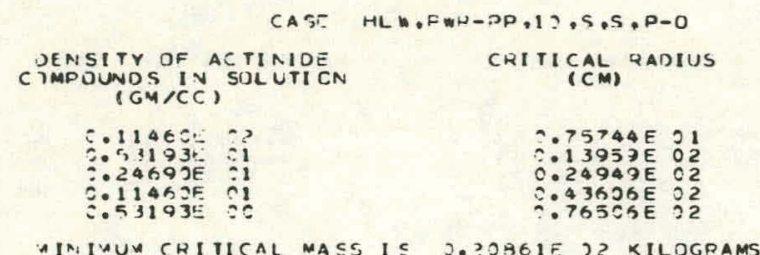

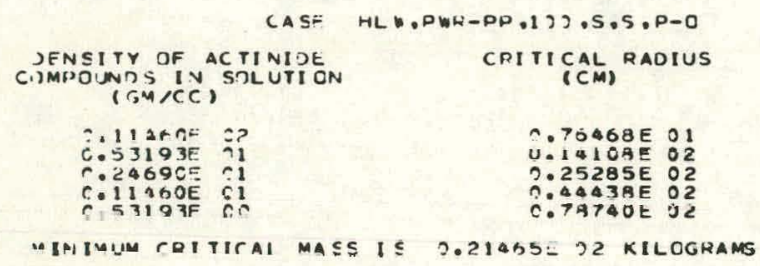

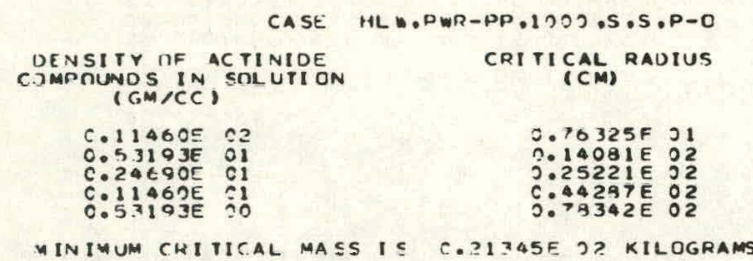

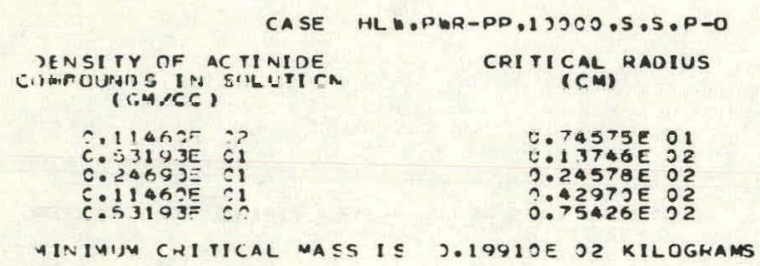

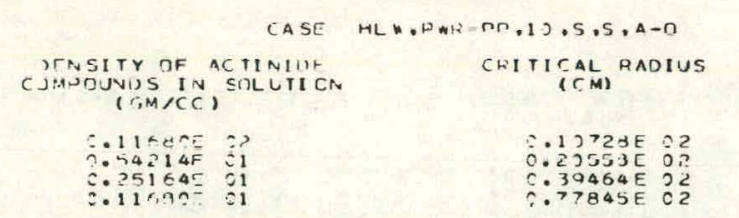

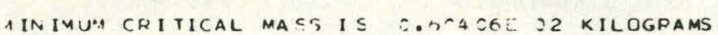

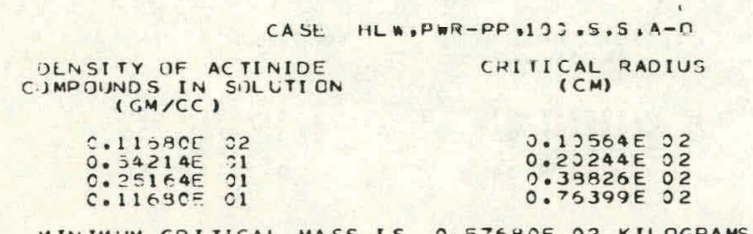

\section{CRIT ICAL MASS \\ $0.20851 F \quad 02$ $0.65607 E \quad 02$ $\begin{array}{lll}0.39804 E & 03 \\ 0.99782 E & 03\end{array}$}

CRITICN ${ }_{(K G)}^{\text {NASS }}$

ग.21465E 02

O.62571F O2

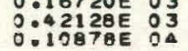

CDITICAL MASS

3.21345502

$0.62210 E$ E 02

$\begin{array}{lll}0.10714 E & 0.4\end{array}$

CRITICM WASS

$0.190117 F$ O

$0.57 A 77 F$ O2

3.038090E 03
CRITICAL MASS
$2.63406 E$ O? $3.19732 E$ O 3 $\begin{array}{lll}0.6478 R E & 3 \\ 0.23091 E & O 4\end{array}$

CRITICA (KG) $^{\text {MASS }}$

$0.57680 E \quad 02$ $0.18843 \mathrm{E} \quad 03$ O.61696E 03
MUL TIPLICATION FACTOR

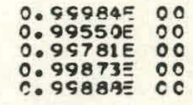

MULTIPLICATION FACTOR

C. 1 COC1E OI

G. 44,14 E 80

0.99864
0.99830

MULIPLICATION FACTOR

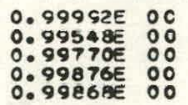

MULTIPLICATION FACTOP

C. $10003 \mathrm{O}$ OI

O. YYSTIE 00

O: $99881 E$ OC 

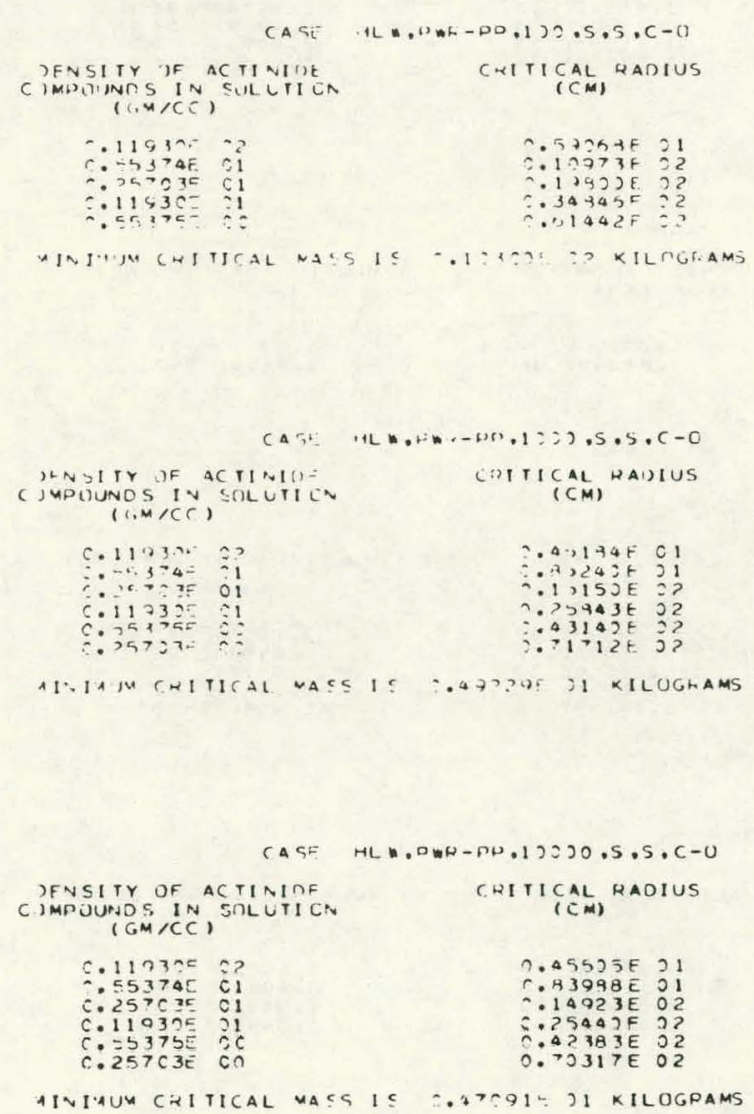

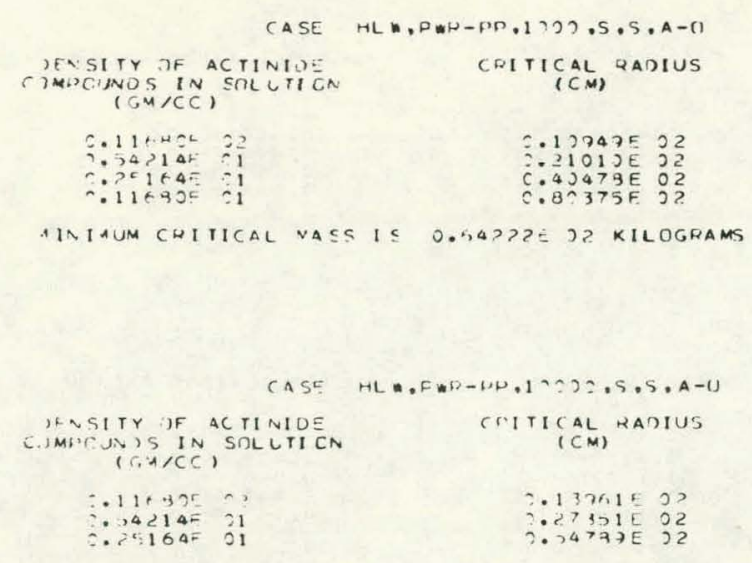

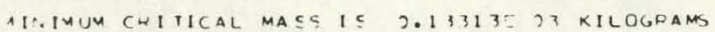

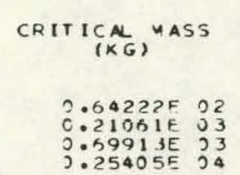

MULTIPLICATIUN FAC TUR

$0.99957=26$ $0.95562 E$ OC
$0.99592=0$

$$
\begin{aligned}
& \operatorname{COIICAN} \text { (KG) MASS } \\
& \left\{\begin{array}{l}
11313 E \quad 03 \\
0.46460 E
\end{array}\right. \\
& \begin{array}{l}
3.46460 \text { E O3 } \\
, .17336 \text { O }
\end{array}
\end{aligned}
$$$$
\text { ..99592E OC }
$$

$$
\begin{aligned}
& \text { CRITICA } \text { (KG) }^{\text {MASS }} \\
& \begin{array}{l}
0.17024 E \\
0.53 C 34 E
\end{array} 02 \\
& 0.53 C 34 E \text { O2 } \\
& 0.46685 \text { E } 03
\end{aligned}
$$

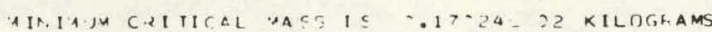

MULTIPLICATION FAE TOR

$0.99975 E 20$

$0.99222 \equiv$ C 00

3:99664 $9563=00$

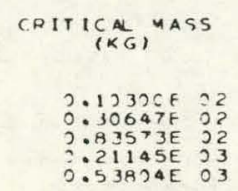

CRITICN ${ }_{(K G)}^{\text {MASS }}$

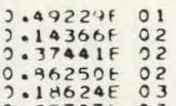

31 त624E O3

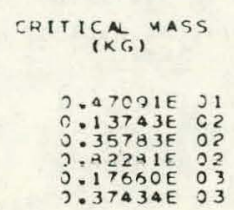



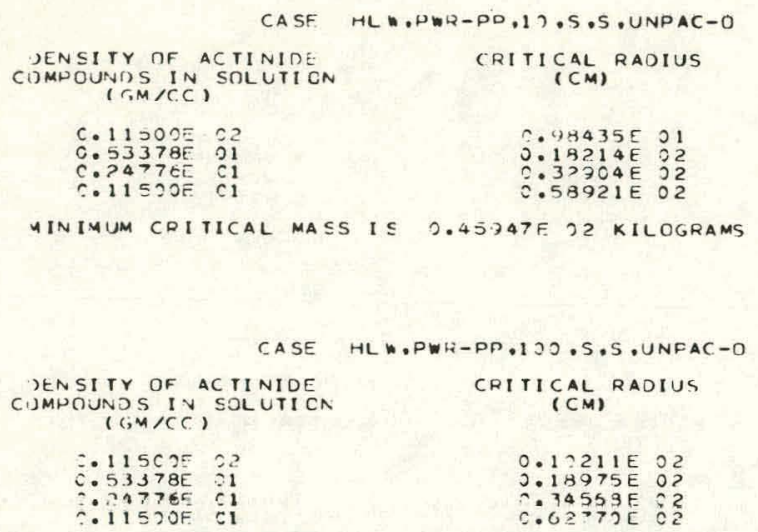

AINIMUM COITICAL MACS IE $2.51288 E$ OZ KILUGRAMS

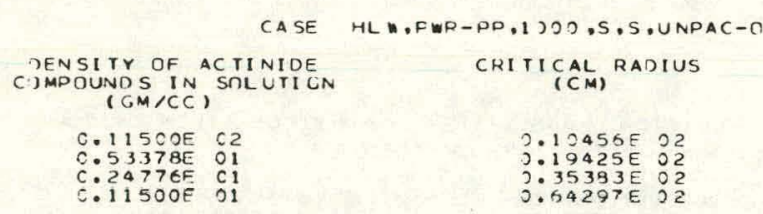

AINIAUM CRITICAL MASS 1 \& $0.55073 \mathrm{E} 22$ KILOGRAMS

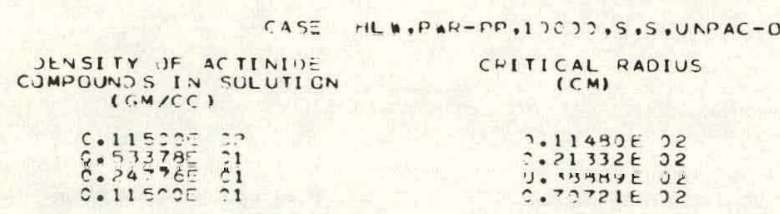

MINIMUM CRITICAL MASS IE ?. ?347L O? KILDGRAMS

\begin{tabular}{|c|c|}
\hline CASE & HEW, FWR-UP, $100000, S, 5, U-0$ \\
\hline $\begin{array}{l}\text { DENSITY OF ACTINIDE } \\
\text { COMPOUNOS IN SOLUTION } \\
\text { (GM,CC) }\end{array}$ & CRITICAL RADIUS \\
\hline $\begin{array}{l}0.1 C S G O E \text { O2 } \\
\text { O. SCOT2E OI }\end{array}$ & $\begin{array}{l}2.36463 E \\
0.73437 E \text { O2 }\end{array}$ \\
\hline
\end{tabular}

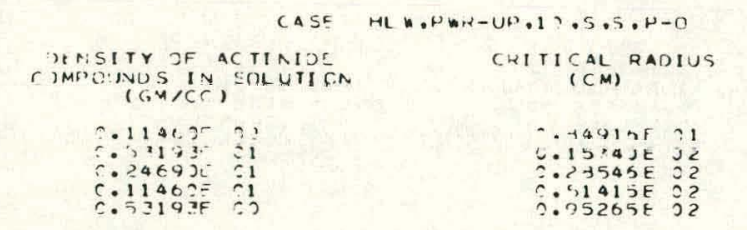

MINIAUM CHITICAL MASS 1 S $.293 .25 \%$ 2? KILDGHAMS

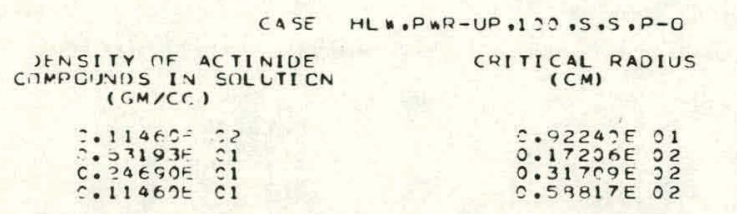

IINIMUNA CRITICAL MASS IS 2.37675 E 22 KILOGRAMS

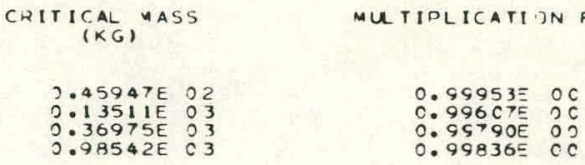

$0.51238 E \quad 02$ $3.15277 E_{0}$
$3.42869 E$ J:11014t 134

MULTIPLICATION FAE TUR 0.99576 C O.: $9775 E$ OO
CRITICAL MASS

0.55073 E 02 0.153 d8E 03 O.4597EE O 3

CHITICA (KG) $^{\text {MASS }}$

3.728976 ?2

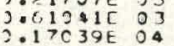

CRITICAL MASS

0.22257
0.843996

MULTIPLICATION FACTIR 0.12001
$0.99982 E 00$ 0. S $778 E$
$0 . \$ 9820 \equiv$

MULTIPLICATION FAC TOR

$0.95956 E$ OF $\begin{array}{ll}C . C S 7 A 2 & \text { nn } \\ \text { C. } 99826 \equiv & O C\end{array}$

$$
\begin{gathered}
\text { CRITICAL, MASS } \\
\text { (KG) } \\
3.37675 E \text { O } 2 \\
3: 113511 \text { O3 } \\
3: 32974 \text { O } 3 \\
\text { J.77679E } 03
\end{gathered}
$$

MUL TIPLICATIUN FAETOR

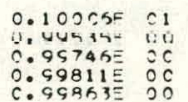

MULTIPLICATION FAC TOR $0.9619=0$
$0.957 C 3 E$
0.997190 $1 C C 1 J E$
0.99513 01 


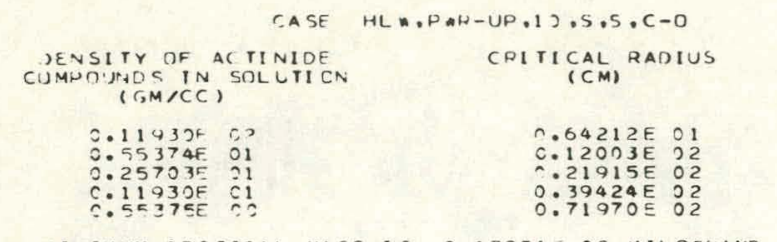

MINIMUM CPITICAL NASS IS 0.13231 E 22 KILOGHAMS

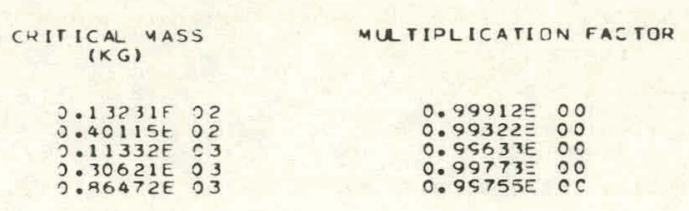

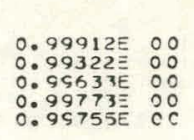

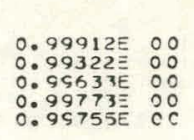

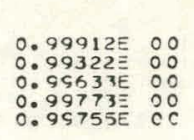

MULTIPLICATION FAE TOR

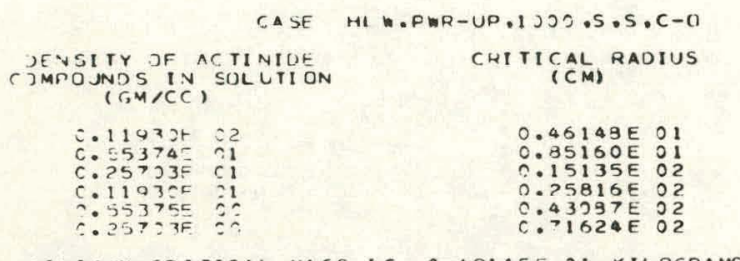

\begin{tabular}{|c|c|}
\hline CASE & 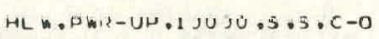 \\
\hline 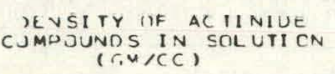 & $\begin{array}{l}\text { CRITICAL RADIUS } \\
\text { (CM) }\end{array}$ \\
\hline 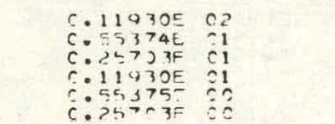 & 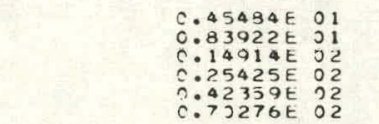 \\
\hline
\end{tabular}

MINIAIJA CHITICAL NASS IS O.27226E OI KILDGHAMS

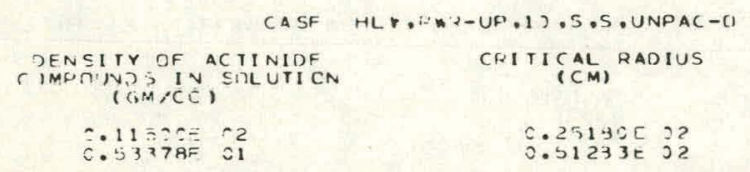

IINIA JM CRITICAL MASS IS $9.75 \% ? 7=23$ KILUGRAMS

$$
\begin{aligned}
& \text { CRITICAL }{ }_{(K G)}^{\text {MASS }} \\
& 3.49115 t \text { U } 1 \\
& 0.14326 E \text { O2 } \\
& 0.85985 \text { E O } \\
& \text { O.18555E } 03
\end{aligned}
$$

HIVIU JM CRITICAL MASS IS ग.29115E ?I KILOGRAMS
MUETIPLICATION FACTOH

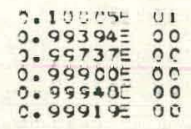

MULTIPLICATION FAC TOR $\begin{array}{ll}0.10005 E & 01 \\ 0.99400 & 00 \\ 0.95750 E & 00 \\ 0.99908 E & 00 \\ 0: 94983 & 00 \\ 0: 95985 & 00\end{array}$
MU. IIPLILATIOUN FAETOR

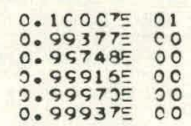

MULTIILICATI JM FACTINH $1 C \div C 1=$
0.11
$399697=20$

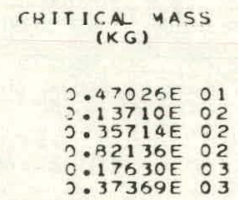

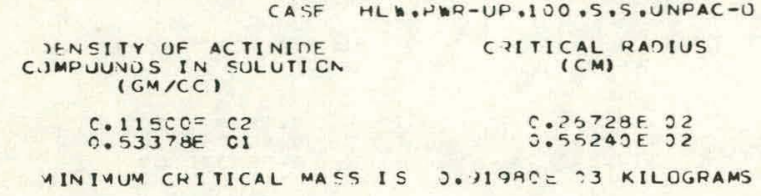



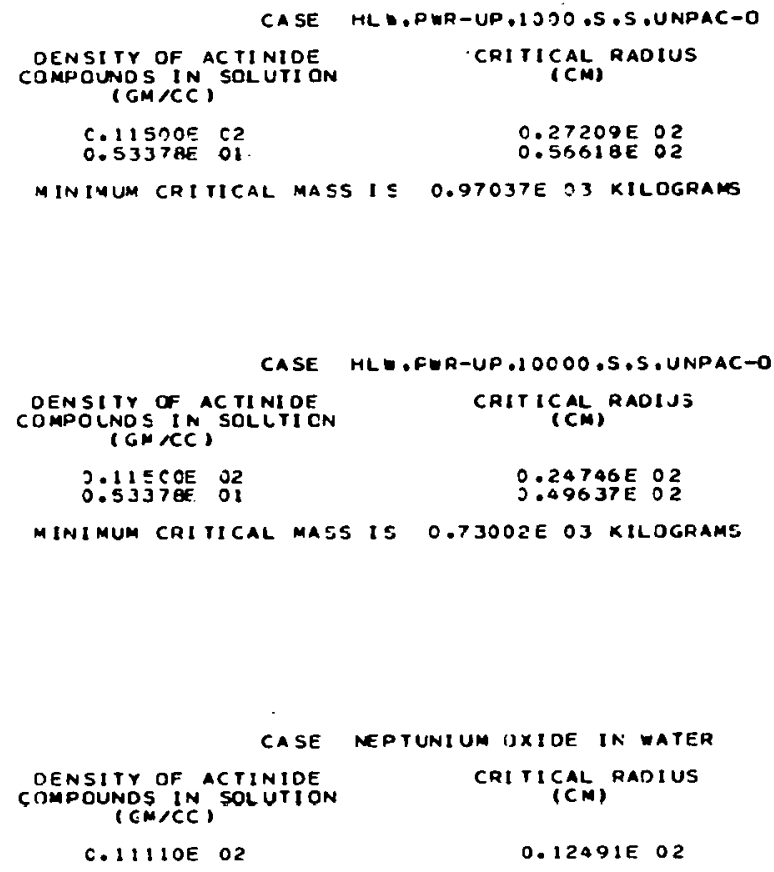

MINIMUM CRITICAL MASS IS $0.90692 E$ O2 KILOGRAMS

$$
\text { CRITICAL VASS }
$$

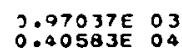

CRITICÁG) AASS

$0.73002 E$
$0.27345 E$

MINIMUM CRITICAL MASS IS $0.73002 E$ O3 KILOGRAMS

\section{CRITICAL, MASS. \\ $0.9009250 ?$}

$0.4+8+2502$

\section{$0.12451 E 02$}

MINIMUM CRITICAL MASS IS C.99842E OZ KILOGRAMS

\section{CRITICAL, MASS \\ 0.44978502 \\ $0.12705 \mathrm{E}$
0.35}

$0.58869 E$ OI

0.35674 O2

MIN IMUM CRITICAL MASS IS 0.44978E O2 KILOGRAMS

CASE MEOTLMIUU OXIOE IN SALT

\begin{tabular}{|c|c|}
\hline $\begin{array}{l}\text { OENSITY UF ACIINIUE } \\
\text { CIOMPOUNDS IN SOLUTION } \\
\text { (CM,CE) }\end{array}$ & CHI ICCAL MAUIUS \\
\hline 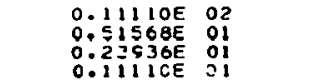 & $\begin{array}{l}0.11664 E \\
022 \\
0.22219 E \text { O2 } \\
0.42529 E .02 \\
0.8514 E \text { C2 }\end{array}$ \\
\hline
\end{tabular}

MINIMUM CRITICAL MASS IS O.T380IE O2 KILOGMAMS

MULTIPLICATION FACTOR

$\begin{array}{ll}0.10001 E & 01 \\ 0.99766 E & 00\end{array}$

MUTIPLICATION FACTOR

$0.10001 E$ OL
0.99730 OO

MULTIPLICATION FACIOP

$0.99922 \div 00$

MULTIPL ICATION FACTOR

0.79929500
MULTIPL ICATION FACTCR

\subsection{0}

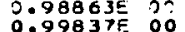

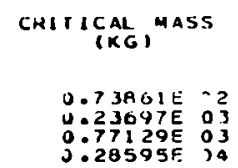

MULTIPLICATION FACTOR

ن.90054t: 0.996705 00 
THIS PAGE

\section{WAS INTENTIONALLY \\ LEFT BLANK}


ORNL/TM- 6458

Dist. Category UC -70

\section{Interna1 Distribution}

1-8. E. J. Allen

9. T. D. Anderson

10. C. F. Baes, Jr.

11. S. Baron

12. M. Bender

13. E. D. Blakcman

14. J. 0. Blomeke

15. A. L. Boch

16. G. D. Brunton

17. H. C. Claiborne

18. J. C. Cleveland

19. L. B. Cobb

20. G. W. Cunningham, III

21-23. L. R. Dole

24. P. D. Fairchild

25. D. E. Ferguson

26. W. E. Ford, III

27. T. B. Fowler

28. A. J. Franke1

29. T. A. Gabriel

30. W. A. Goldsmith

31. N. M. Greene

32. J. F. Harvey

33. R. F. Hibbs

34. C. R. Hudson, II

35. R. D. Hurt

36. J. D. Jenkins

37-39. G. H. Jenks

40. J, S. Johnson, Jr.

41. H. T. Kerr

42. R. K. Kibbe

43. R. A. Kisner

44. R. B. Lughon

45. M. Levenson

46. T. F. Lomenick

47. R. S. Lowrie
48. F. C. Maienschein

49. S. C. Matthews

50. L. L. McCauley

51. W. C. McClain

52. S. R. McNeany

53. J. F. Mincey

54. J. M. Morrison

55. A. R. Olsen

56. W. H. Pechin

57. H. Postma

58. R. T. Primm

59. A. S. Quist

60. J. E. Rushton

61. J. E. Russe11

62. L. B. Shappert

63. M. R. Sheldon

64. R. L. Shoup

65. I. I. Siman-Tov

66. C. S. Sims

67. I. Spiewak

68. E. G. St.Clair

69. I. L. Thomas

70. W. E. Thomas

71. H. E. Trammell

72. D. B. Trauger

73. J. E. Vath

74. D. R. Vondy

75. C. C. Webster

76. J. R. Weir

77. R. M. Westfall

78-92. Office of Waste Isolation

93-94. Central Research Library

95. Document Reference Section

96. ORNL Patent Section

97-99. Laboratory Records Department

100. Laboratory Records, ORNL (RC)

\section{Externa1 Distribution}

101. Director, DOE, ORO

102. Director, Research and Technical Support Division, DOE, ORO

103. Director of Reactor Division, DOE, ORO

104-123. J. J. Schreiber, Director, Waste Management Division, U.S. Department of Energy, Oak Ridge, TN 37830

124-125. F. R. Standerfer, Department of Energy, Richland Operations, Richland, WA 99352 
126. J. W. Bartlett, Battelle Pacific Northwest Laboratory, P.o. Box 999, Richland, WA 99352

127-131. J. M. Batch, Battelle Memorial Institute, Columbus Laboratories, 505 King Avenue, Columbus, OH 43201

132. D. G. Brookins, Department of Geology, University of New Mexico, Albuquerque, NM 87131

133. C. L. Brown, Battelle Pacific Northwest Laboratory, P.0. Box 999, Richland, WA 99352

134. H. C. Burkholder, Battelle Pacific Northwest Laboratory, P.0. Box 999, Richland, WA 99352

135. G. A. Cowan, University of California, Los Alamos Scientific Laburalusy, P.0. Box 1663, Los A1.smos, NM 87545

136. J. T. Crandall, Nuclear Engineering Section, E. I. duPont deNemours and Company, Atomle: Finergy Division, Savannah River Laboratory, Aiken, SC 29801

137. C. W. Craven, Jr., Science Applications, Inc., 800 Oak Ridge Turnpike, Oak Ridge, TN 37830

138. J. H. Crawford, Department of Physics, University of North Carolina at Chapel Hill, Chapel Hill, NC 27514

139. S. N. Davis, Department of Hydrology and Water Resources, University of Arizona, Tucson, AZ 85912

140. R. A. Deju, Rockwe1.1 Hanford Operations, Department of Waste Isolation, Columbia Bank Building, Richland, WA 99352

141. F. A. Donath, Sandia Laboratories, Division 5413, Fuel Cycle Risk Analysis, Albuquerque, NM 87115

142. L. H. Gevantman, Office of Standard Reference Data, United States Department of Commerce, National Bureau of Standards, Washington, DC 20234

143. P. F. Gnirk, RE/SPEC Inc., P.0. Box 725, Rapid City, SD 57701

144. D. Isherwood, University of California, Lawrence Livermore Laboratory, P.0. Bux 808, Livermore, CA 94550

145. J. F. Kircher, Battelle Memorial Institute, Columbus Laboratorles, 505 King Avenue, Columbus, OH 43201

146. D. A. Kottwitz, Battelle Pacific Northwest Laboratory, P.o. Bux 999 , Richland, Wh 99352

147. P. W. Levy, Associated Universities, Inc., Brookhaven National Laboratory, Upton, NY 1197.3

148. J. A. Ticherman, Nuclear Safety Associates, 5101 River Roar, Bethesda, Maryland 20016

1.49. J. D. Martinez, Louisiana State University, Department of Environmental Sciences, Baton Rouge, LA 70803

150. D. P. Moak, Battelle Memorial Institute, Columbus Laborảtóries, 505 King Avenue, Columbus, OH 43201

151. D. M. Roy, Pennsylvania State University, Materials Research Laboratory, University Park, PA 16802

1.52. B. E. Russel1, Richland Branch, Fenix and Scisson, Inc., P.o. Box 1073, Columbia Bank Building, Richland, WA 99352

153. R. L. Schwoebel, University of California, Los Alamos Scientific Laboratory, P.0. Box 1663, Los Alamos, NM 87545

154. M. Steindler, Argonne National Laboratory, 9700 South Cass Avenue, Argonne, IL 60439 
155. D. B. Stewart, United States Geological Survey, National Center, Mail Stop 432, Reston, VA 22092

156. W. S. Twenhofel, U.S. Geological Survey, Box 25046, Denver Federal Center, Denver, Co 80225

157. W. D. Weart, Sandia Laboratories, P.0. Box 5800, Albuquerque, NM 87115

158. C. E. Weaver, School of Geophysical Sciences, Georgia Institute of Technology, Atlanta, GA 30332

159. J. W. Winchester, Department of Oceanography, Florida State University, Tallahassee, Florida 32306

160. P. A. Witherspoon, Lawrence Berkeley Laboratories, University of California, Berkeley, CA 94720

161-427. For distribution as shown in TID-4500 under UC-70, Nuclear Waste Mänagement. 